FINAL

\title{
INCREASED OIL PRODUCTION AND RESERVES UTILIZING SECONDARY/TERTIARY RECOVERY TECHNIQUES ON SMALL RESERVOIRS IN THE PARADOX BASIN, UTAH
}

\section{FINAL REPORT}

\author{
Thomas C. Chidsey, Jr., Compiler and Editor
}

November 2002

Performed Under Contract No. DE-FC22-95BC14988

Utah Geological Survey

Salt Lake City, Utah 84114

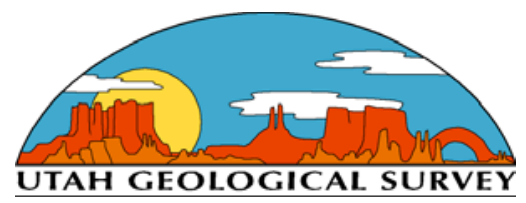

U.S. Department of Energy

National Petroleum Technology Office

One West $3^{\text {rd }}$ Street

Tulsa, OK 74103 


\section{DISCLAIMER}

This report was prepared as an account of work sponsored by an agency of the United States Government. Neither the United States Government nor any agency thereof, nor any of their employees, makes any warranty, express or implied, or assumes any legal liability or responsibility for the accuracy, completeness, or usefulness of any information, apparatus, product, or process disclosed, or represents that its use would not infringe privately owned rights. Reference herein to any specific commercial product, process, or service by trade name, trademark, manufacturer, or otherwise does not necessarily constitute or imply its endorsement, recommendation, or favoring by the United States Government or any agency thereof. The views and opinions of authors expressed herein do not necessarily state or reflect those of the United States Government or any agency thereof. 
FINAL

\section{INCREASED OIL PRODUCTION AND RESERVES UTILIZING SECONDARY/TERTIARY RECOVERY TECHNIQUES ON SMALL RESERVOIRS IN THE PARADOX BASIN, UTAH}

\section{FINAL REPORT}

Thomas C. Chidsey, Jr., Compiler and Editor

November 2002

Work Performed Under Contract No. DE-FC22-95BC14988

Prepared for

U.S. Department of Energy

Assistant Secretary for Fossil Energy

Gary D. Walker, Project Manager

National Petroleum Technology Office

One West $3^{\text {rd }}$ Street

Tulsa, OK 74103

Prepared by

Utah Geological Survey

Salt Lake City, Utah 84114

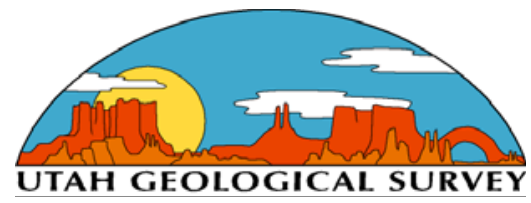

US/DOE Patent Clearance is not required prior to the publication of this document. 


\section{CONTENTS}

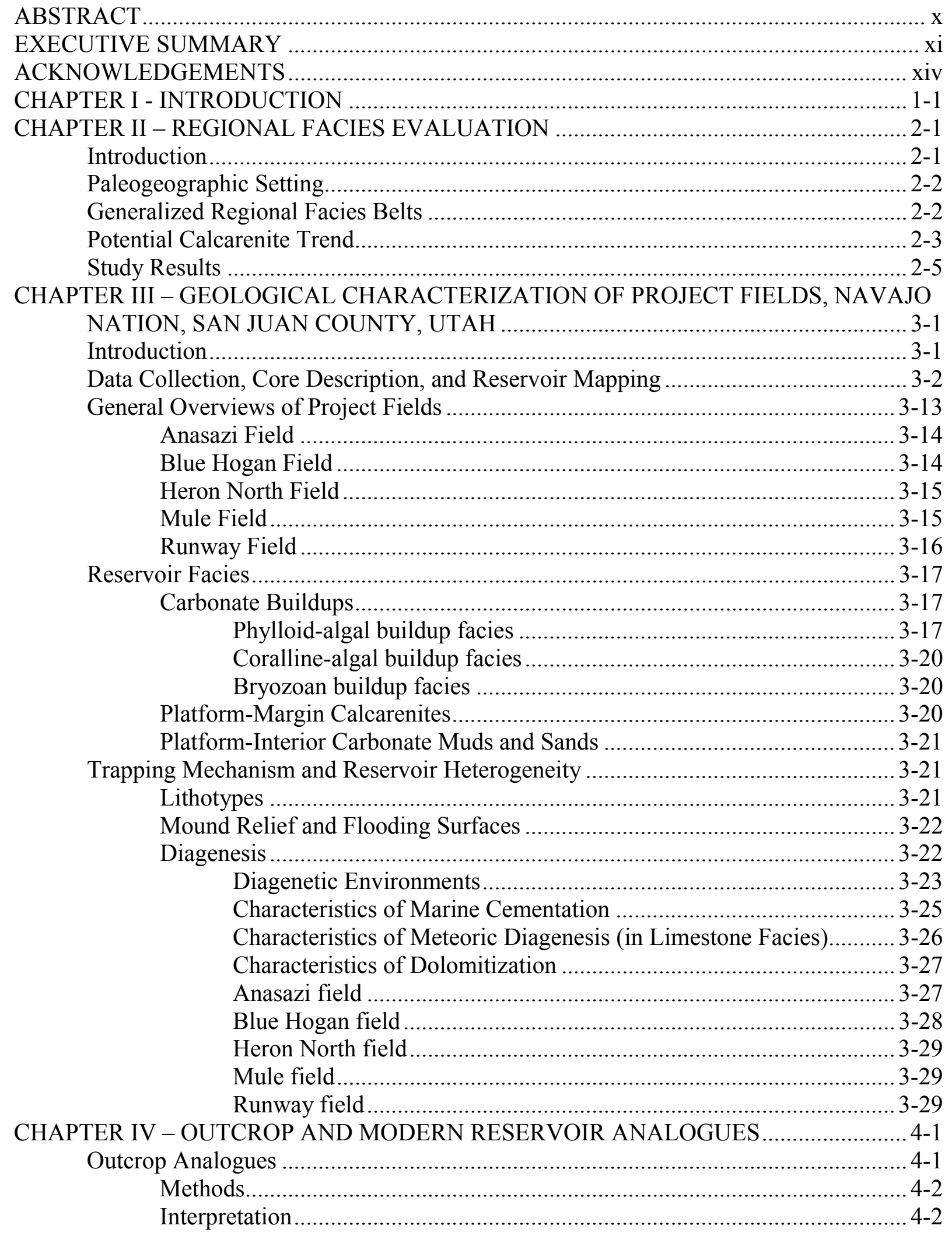




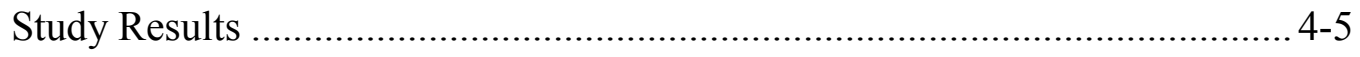

Modern Analogues .......................................................................................................... 4-5

CHAPTER V - PROJECT DRILLING AND SEISMIC PROGRAMS ................................ 5-1

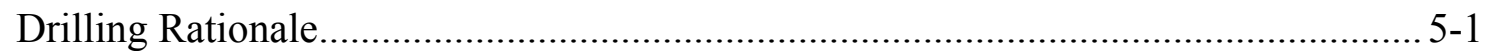

Anasazi No. 6H-1 Well, Anasazi Field.................................................................. 5-1

New Seismic Data and Horizontal Drilling, Mule Field............................................... 5-2

Seismic Acquisition ……………………………………........................... 5-2

Horizontal Sidetrack ............................................................................

Horizontal Completion................................................................................... 5-6

CHAPTER VI - RESERVOIR MODELING OF THE DESERT CREEK ZONE ................... 6-1

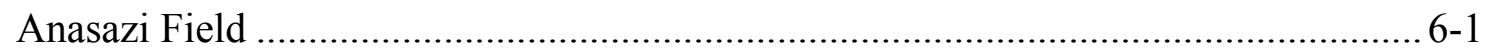

Geometry and General Stratigraphy ……………….................................... 6-1

Reservoir Architecture ............................................................................... 6-2

Reservoir Model Geometry...................................................................... 6-10

Seismic Constraints............................................................................. 6-10

Reservoir Model Design ......................................................................... 6-12

Geostatistical Models.......................................................................... 6-14

Architectural Modeling ................................................................ 6-17

Porosity Modeling.......................................................................... 6-17

Fifteen-layer simulation model ................................................... 6-18

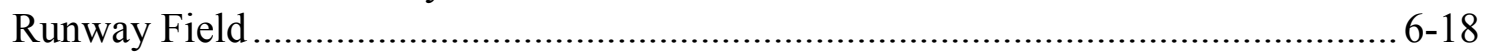

Geometry and General Stratigraphy ……………………........................... 6-18

Reservoir Architecture ......................................................................... 6-22

Reservoir Modeling Geometry ……………………............................... 6-22

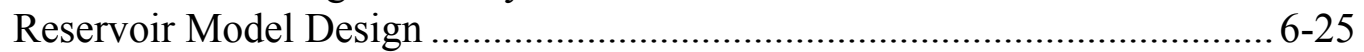

Geostatistical Models............................................................................ 6-26

CHAPTER VII - ENGINEERING RESERVOIR CHARACTERIZATION OF THE CARBONATE RESERVOIR IN THE DESERT CREEK ZONE .............................. 7-1

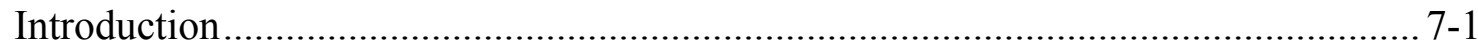

Review of Existing Field Data and Re-evaluation of Well Test Data .......................... 7-1

Basic Reservoir Engineering Analysis of the Five Project Fields ..................... 7-1

Field Data Review.................................................................................. $7-1$

Well Test Data Re-Evaluation ................................................................

Fluid Characterization.................................................................................... 7-10

Sample Preparation and Compositional Analysis........................................... 7-11

Separator Oils...........................................................................

Separator Gases...................................................................... 7-11

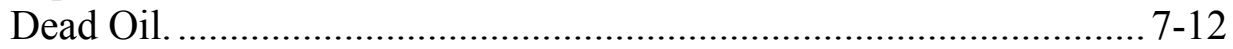

Fluid Recombination and Swelling Tests .................................................. 7-12

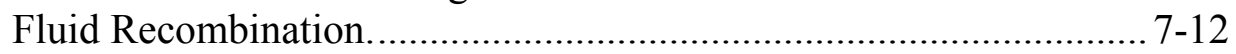

Swelling Tests..................................................................

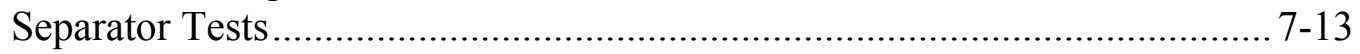

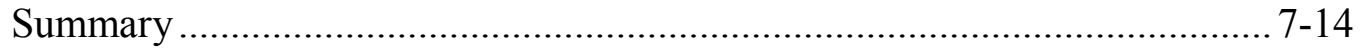

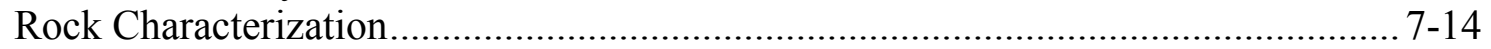

Computerized Axial Tomography ............................................................. 7-15

Relative Permeability Measurements .......................................................... 7-16 
Fluid Measurements

Experimental Procedures. ............................................................... 7-17

Resaturation and Kew Measurements........................................... 7-17

Initial Oil/Brine Drainage Experiment and Aging............................ 7-18

Brine/Oil Imbibition Capillary Pressure Test. .................................... 7-18

Kew Measurements and Oil/Brine Secondary Drainage Test. ........... 7-18

Brine/Oil Imbibition Relative Permeability Test. ................................. 7-19

Oil/Brine Drainage Relative Permeability Test. .................................. 7-19

Gas/Oil Capillary Pressure and Relative

Permeability Experiment …………………………................... 7-21

Final Saturation Determination via Dean-Stark............................... 7-23

Gas Property Measurements. ..................................................... 7-24

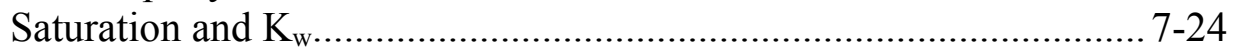

Primary Drainage Capillary Pressure Measurements. ……………..... 7-24

U.S. Bureau of Mines and Amott Wettability Indices....................... 7-24

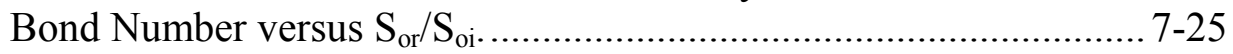

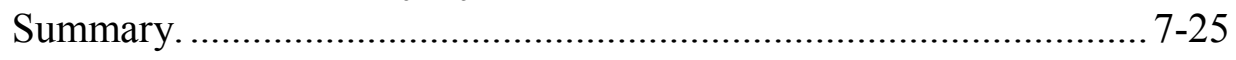

Rock Compressibility Measurements ……………………………………... 7-25

CHAPTER VIII - MECHANISTIC RESERVOIR SIMULATION STUDIES........................ 8-1

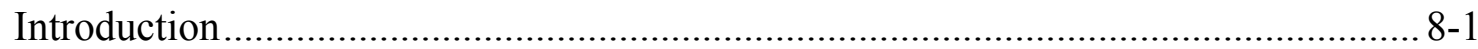

One- and Two-Dimensional Compositional Simulation Studies.................................. 8-1

Model Description ................................................................................... 8-2

Fluid Properties and Production Data ........................................................... 8-2

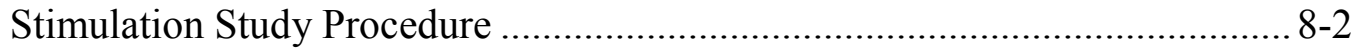

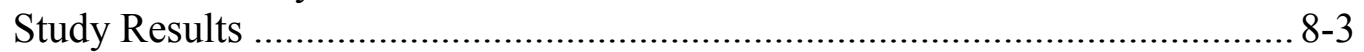

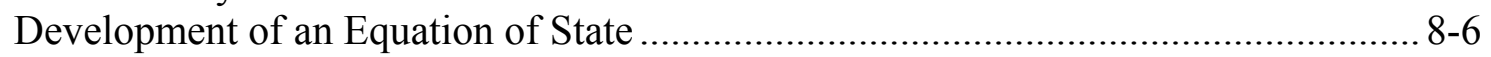

Reservoir Simulation: Anasazi Field .................................................................. 8-6

History Matching …………………………………............................. 8-9

Reservoir Performance Prediction Studies Using $\mathrm{CO}_{2}$ Injection.................... 8-12

Reservoir Performance Prediction Studies Using Water Injection.................. 8-17

Reservoir Simulation: Runway Field ............................................................... 8-17

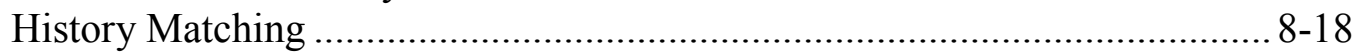

Reservoir Performance Prediction Studies Using $\mathrm{CO}_{2}$ Injection................... 8-18

CHAPER IX - ECONOMIC ASSESSMENTS OF RESERVOIR $\mathrm{CO}_{2}$ FLOODS AND

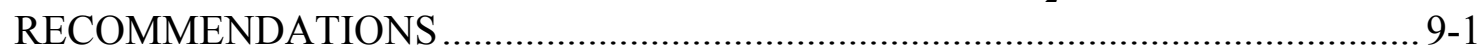

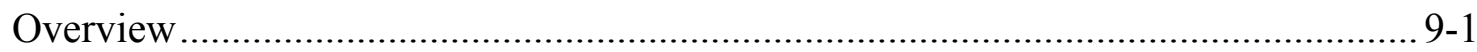

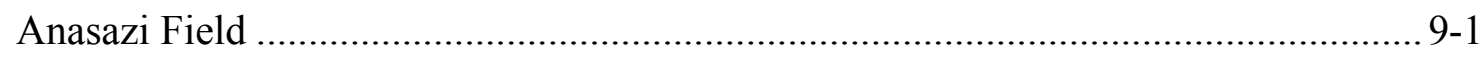

Economic Assessment of $\mathrm{CO}_{2}$ Flood .......................................................... 9-1

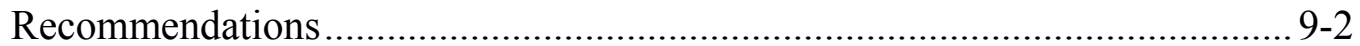

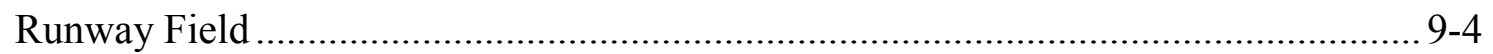

Economic Assessment of $\mathrm{CO}_{2}$ Flood........................................................ 9-4

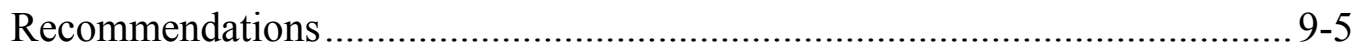

Reserve and Recovery Determinations for Project Fields .......................................... 9-6

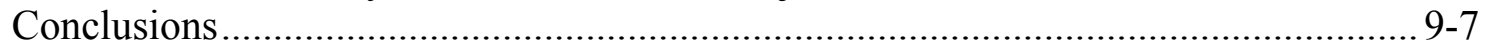

CHAPER X - IMPLEMENTATION OF PILOT $\mathrm{CO}_{2}$ FLOOD DEMONSTRATION .......... 10-1

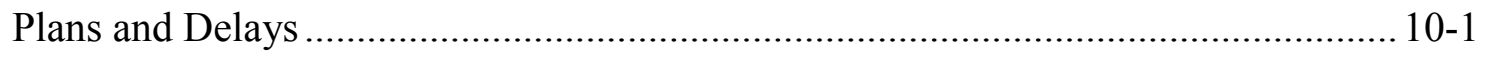

Options and Current Status ................................................................................ 10-1 
REFERENCES …............................................................................................. R-1 APPENDIX - UTAH GEOLOGICAL SURVEY DOE PARADOX BASIN CLASS II PROJECT PUBLICATIONS ............................................................................ A-1

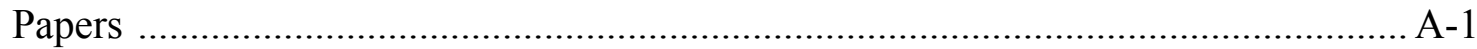

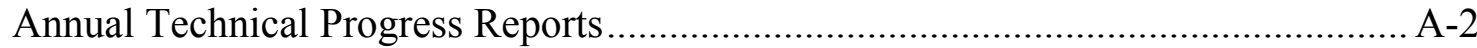

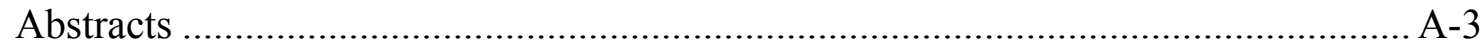

Utah Geological Survey Internet Web Site.......................................................... A-4

Utah Geological Survey Petroleum News............................................................... A-4 


\section{FIGURES}

Figure 1-1. Location of project fields, southeastern Utah

Figure 2-1. Generalized regional facies belts for Desert Creek zone, Pennsylvanian Paradox

Formation, southeastern Utah ....

Figure 2-2. Block diagram displaying major facies within regional facies belts for the Desert

Creek zone, Pennsylvanian Paradox Formation, southeastern Utah.

Figure 2-3. Regional facies belts of the Desert Creek zone, Paradox Formation, and potential

calcarenite buildup trend, southeastern Utah....

Figure 2-4. Depositional environments of the calcarenite facies........................................ 2-4

Figure 3-1. Typical Desert Creek vertical sequence from the Anasazi field ........................ 3-3

Figure 3-2. Typical Desert Creek vertical sequence from the Blue Hogan field.....................3-4

Figure 3-3. Typical Desert Creek vertical sequence from the Heron North field................... 3-5

Figure 3-4. Typical Desert Creek vertical sequence from the Mule field ............................ 3-6

Figure 3-5. Typical Desert Creek vertical sequence from the Runway field........................ 3-7

Figure 3-6. Combined Desert Creek zone structure contour and gross interval isopach map,

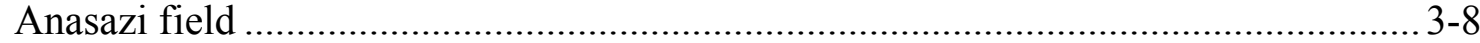

Figure 3-7. Combined Desert Creek zone structure contour and gross interval isopach map,

Blue Hogan field ........................................................................................ 3-9

Figure 3-8. Combined Desert Creek zone structure contour and gross interval isopach map,

Heron North field ....................................................................................... 3-10

Figure 3-9. Combined Desert Creek zone structure contour and gross interval isopach map,

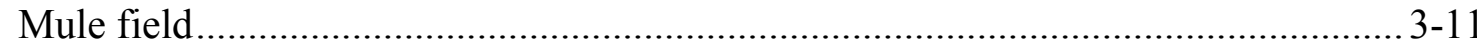

Figure 3-10. Combined Desert Creek zone structure contour and gross interval isopach map,

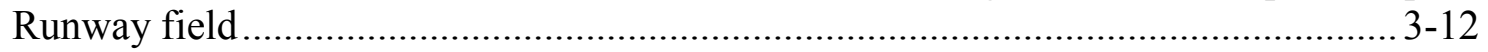

Figure 3-11. Representative seismic line across Mule field ....................................... 3-13

Figure 3-12. Core of highly productive, dolomitized, phylloidal-algal bafflestone from the Mule No. 31-M well ......................................................................................... 3-16

Figure 3-13. Three-dimensional "net" view on top of the Mississippian Leadville Limestone and the north-bounding faults which control carbonate buildups.......................... 3-16

Figure 3-14. Map view of typical carbonate buildup shapes on the shallow carbonate shelf during Desert Creek time ................................................................................. 3-18

Figure 3-15. Detailed environmental setting of Desert Creek algal buildup features surrounding the Greater Aneth field..................................................................................... 3-19

Figure 3-16. Probable flooding surface or 5th-order parasequence in the Anasazi field...... 3-22

Figure 3-17. Core photograph of the highly dolomitized, oil-saturated calcarenite section of the

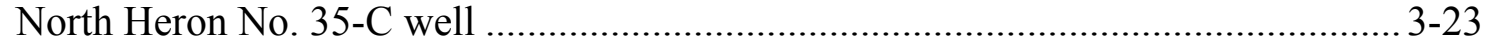

Figure 3-18. Model of early diagenetic environments ................................................. 3-24

Figure 3-19. Ideal diagenetic sequence through time .................................................. 3-24

Figure 3-20. Slabbed core segments from the Blue Hogan No. 1-J-1 well ........................ 3-25

Figure 3-21. Photomicrograph of two generations of marine cements............................. 3-25

Figure 3-22. Photomicrograph of interconnected solution channel and moldic porosity...... 3-26

Figure 3-23. Photomicrograph of early solution porosity within a phylloid-algal facies...... 3-26

Figure 3-24 Photomicrograh of a wackestone/packstone showing seepage reflux/hypersaline

and mixing zone dolomitization................................................................ 3-27

Figure 3-25. Photmicrograph of dolomitized pelloidal/oolitic/bioclastic grainstone ............ 3-28 
Figure 4-1. Location of Paradox Formation outcrops in the Wild Horse Canyon area along the San Juan River, southeastern Utah....................................................................... 4-1

Figure 4-2. Photomosaic and interpretation of the phylloid-algal mound complex of the lower Ismay zone in Wild Horse Canyon ............................................................................. 4-3

Figure 4-3. Outcrops in the Ismay zone of the Paradox Formation, Wild Horse Canyon ...... 4-3

Figure 4-4. Block diagram displaying depositional interpretation of Wild Horse Canyon mound

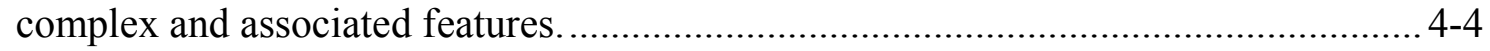

Figure 4-5. Reservoir rock from Mule field, Utah........................................................ 4-6

Figure 4-6. Satellite image of Florida Bay................................................................. 4-6

Figure 4-7. Depositional environments of Florida Bay .................................................. 4-7

Figure 4-8. Islands along Florida Bay mud banks; inset - turtle grass Thalassia .................. 4-8

Figure 4-9. Depositional facies of Mule, Brown Hogan, Jack, and Anasazi fields, Paradox

Basin, Utah............................................................................................... 4-9

Figure 4-10. Shallow marine sandbanks, Schooner Cays; satellite image of the Great Bahama

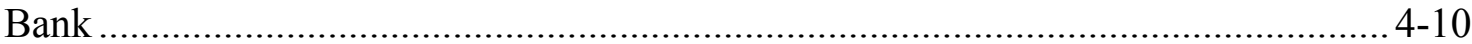

Figure 4-11. Satellite image of Shark Bay, western coast of Australia; inset - bedded anhydrite from Coral No. 11A-1 wildcat well, San Juan County, Utah ................................. 4-11

Figure 5-1. Migrated seismic line defining the Mule field algal mound buildup ..................5-3

Figure 5-2. Ismay zone to Desert Creek zone isochron map, Mule field area...................... 5-4

Figure 5-3. Drilling operations for the Mule 31-K-1 horizontal sidetrack well, Utah............ 5-4

Figure 5-4. Schematic diagram of the facies encountered by the Mule 31-K-1 horizontal sidetrack well ...................................................................................... 5-5

Figure 5-5. Production graph for the Mule 31-K-1 horizontal sidetrack well ...................... 5-6

Figure 6-1. Gross Desert Creek isopach based on geophysical well log and seismic data, Anasazi field

Figure 6-2. Stratigraphic cross section across Anasazi field displaying reservoir lithotypes, flooding surfaces, and facies relations within the Desert Creek platform, mound-core,

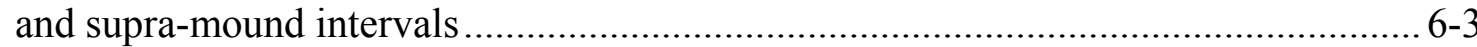

Figure 6-3. Computed geophysical well logs and lithology plots of the

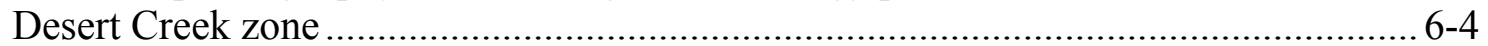

Figure 6-4. Photomicrographs showing low-quality architectural lithotypes...................... 6-6

Figure 6-5. Photomicrographs showing high-quality architectural lithotypes..................... 6-7

Figure 6-6. Photomicrographs showing moderate- to high-quality

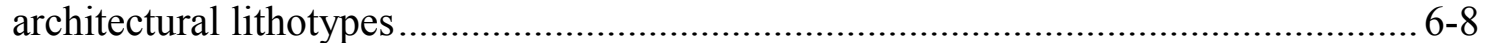

Figure 6-7. Photomicrograph showing a phylloid-algal bafflestone from the Anasazi No. 1 well ........................................................................................... 6-9

Figure 6-8. Anasazi reservoir gridded isolith map.................................................. 6-11

Figure 6-9. Reservoir quality index map with seismic data points, Anasazi reservoir......... 6-11

Figure 6-10. Estimation of average porosity from the reservoir quality index, Anasazi reservoir 6-12

Figure 6-11. Map of average porosity derived from the reservoir quality index, Anasazi reservoir

Figure 6-12. Cross section of the 50-layer geostatistical Anasazi reservoir simulation model displaying the spatial distribution of lithotypes. 6-15

Figure 6-13. Spatial distribution of lithotypes at layer 30 from the 50-layer geostatistical Anasazi reservoir simulation model. 
Figure 6-14. Cross section of the 15-layer geostatistical Anasazi reservoir simulation model displaying the spatial distribution of lithotypes

Figure 6-15. Spatial distribution of lithotypes at layer nine from the 15-layer geostatistical Anasazi reservoir simulation model 6-16

Figure 6-16. Block diagram displaying distribution of lithotypes in the 15-layer reservoir simulation model, Anasazi field

Figure 6-17. Block diagram displaying distribution of porosity in the 15-layer reservoir simulation model, Anasazi field

Figure 6-18. Block diagram displaying distribution of permeability in the 15-layer reservoir simulation model, Anasazi field

Figure 6-19. Carbonate isolith map of the Desert Creek reservoir, Runway field $6-23$

Figure 6-20. Average porosity grid of the Desert Creek reservoir, Runway field. 6-24

Figure 6-21. Runway field simulation grid and well locations $6-24$

Figure 6-22. Spatial distribution of lithotypes at Layer 4 from the 17-layer geostatistical Runway reservoir simulation model....

Figure 6-23. Spatial distribution of porosity at Layer 4 from the 17-layer geostatistical Runway reservoir simulation model

Figure 6-24. East-west cross section of the 17-layer geostatistical Runway reservoir simulation model displaying the spatial distribution of lithotypes in the Desert Creek and Ismay zones $6-27$

Figure 7-1. Annual production graphs for project fields . 7-3

Figure 7-2. Anasazi No. 1 well test displaying pressure difference and pressure derivative match.

Figure 7-3. Anasazi No. 1 well test displaying superposition time vs. pressure match.......... 7-8

Figure 7-4. Anasazi No. 1 well test displaying pressure vs. time match ............................. 7-9

Figure 7-5. Runway No. 10-E-2 well, zone 2 test pressure derivative and pressure difference

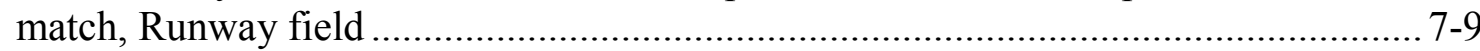

Figure 7-6. Runway No. 10-E-2 well, zone 2 test superposition plot match,

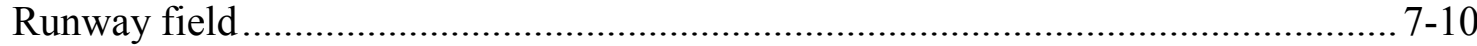

Figure 7-7. Comparison of the weight-percent composition measured for the flashed separator oil and dead oil samples.

Figure 7-8. A set of CAT scans of two mutually perpendicular longitudinal-axial sections of each of the four core plugs taken from the Anasazi No. $6 \mathrm{H}-1$ well.......................... $7-15$

Figure 7-9. Pore-size distribution plots for Anasazi field........................................... 7-16

Figure 7-10. Brine - oil primary imbibition capillary pressure curves from elevated temperature, automated centrifuge data for Anasazi No. $6 \mathrm{H}-1$ well ........................ 7-18

Figure 7-11. Oil - brine secondary drainage capillary pressure curves from elevated temperature, automated centrifuge data for Anasazi No. 6H-1 well

Figure 7-12. Oil - brine relative permeability curves from elevated temperature, automated centrifuge data for Anasazi No. 6H-1 well

Figure 7-13. Oil - brine primary drainage capillary pressure curve from elevated temperature, automated centrifuge data for Anasazi No. 6H-1 well

Figure 7-14. Gas - oil drainage capillary pressure curve from elevated temperature, automated centrifuge data for Anasazi No. 6H-1 well

Figure 7-15. Gas - oil relative permeability curves from elevated temperature, automated centrifuge data for Anasazi No. 6H-1 well 
Figure 7-16. Bond number vs. $\mathrm{S}_{\mathrm{or}} / \mathrm{S}_{\mathrm{oi}}$ curves from elevated temperature, automated centrifuge data for Anasazi No. 6H-1 well

Figure 8-1. Results of two-dimensional reservoir simulation of the Anasazi field ....

Figure 8-2. Two-dimensional reservoir simulation of the Anasazi field showing gas saturation for XZ plane after 1,461 days of production........................................................ 8-5

Figure 8-3. Schematic reservoir simulator model of the Anasazi reservoir .......................... 8-5

Figure 8-4. Well-flow buildup test analysis of the Big Sky No. 6E well near Clay Hill field displaying pressure vs. time match

Figure 8-5. Well-flow buildup test analysis of the Big Sky No. 6E well displaying pressure difference and pressure derivative match ............................................................ 8-7

Figure 8-6. Variation of composition of both liquid and vapor phases as a function of time for selected cell in the one-dimensional model ............................................................. 8-8

Figure 8-7. Anasazi field oil production rate and cumulative oil production vs. time from history match runs of the two-dimensional reservoir simulation.............................. 8-10

Figure 8-8. Anasazi field gas production rate and predicted cumulative gas production vs. time from history match runs of the two-dimensional reservoir simulation.

Figure 8-9. Cross section of the Anasazi reservoir grid-system model illustrating gas saturation distribution as of December 31, 1996.

Figure 8-10. Cross section of the Anasazi reservoir grid-system model illustrating reservoir pressure distribution as of December 31, 1996.

Figure 8-11. Anasazi field oil-production rate and cumulative oil production comparing primary depletion and $\mathrm{CO}_{2}$ flooding vs. time

Figure 8-12. Block diagram displaying reservoir oil saturation at the start of $\mathrm{CO}_{2}$ injection

Figure 8-13. Block diagram displaying reservoir oil saturation after 10 years of $\mathrm{CO}_{2}$ injection.

Figure 8-14. Oil recovery - primary versus continuous $\mathrm{CO}_{2}$ injection, Anasazi field.......... 8-15

Figure 8-15. Oil recovery - primary versus waterflood, Anasazi field ............................. 8-17

Figure 8-16. Oil recovery - primary depletion versus continuous $\mathrm{CO}_{2}$ flood injection/flood

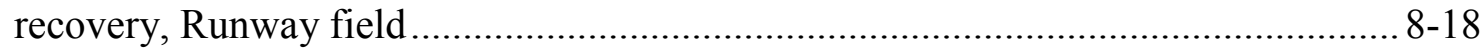

Figure 8-17. Block diagram displaying reservoir oil saturation distribution at the start of $\mathrm{CO}_{2}$ injection

Figure 8-18. Block diagram displaying reservoir oil saturation distribution after 4.5 years of $\mathrm{CO}_{2}$ injection, Runway field ....................................................................... 8-20

Figure 9-1. Rate of return versus price of oil, Anasazi field $\mathrm{CO}_{2}$ flood at high rate ............. 9-3

Figure 9-2. Net present value versus price of oil, Anasazi field $\mathrm{CO}_{2}$ flood at high rate ........ 9-3

Figure 9-3. Rate of return versus price of oil, Runway field $\mathrm{CO}_{2}$ flood at high rate............. 9-5

Figure 9-4. Net present value versus price of oil, Runway field $\mathrm{CO}_{2}$ flood at high rate ........ 9-6 


\section{TABLES}

Table 3-1. Cumulative production of project fields in the Paradox Basin, Utah................... 3-1

Table 3-2. Geological and engineering data for project fields in the

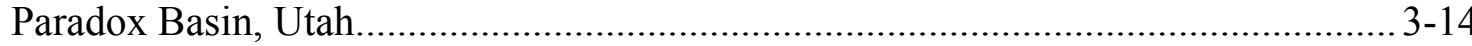

Table 6-1. Average reservoir properties of architectural lithotypes, Anasazi field............... 6-9

Table 7-1. Petrophysical properties and pressure data for project fields............................ 7-2

Table 7-2. Oil, gas, and water properties for project fields. .......................................... 7-2

Table 7-3. Swelling test data for the Anasazi No. 5L-3 oil. ......................................... 7-13

Table 7-4. Separator test volumetric data. .................................................................. 7-14

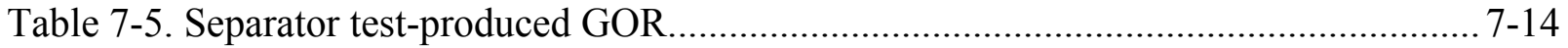

Table 7-6. Brine composition. .................................................................................. $7-17$

Table 7-7. Fluid properties...................................................................................... 7-17

Table 7-8. Permeability and porosity data summary for the Anasazi No. 6H-1............... 7-22

Table 7-9. Pre-test sample conditions and physical properties for selected samples from the

Anasazi Nos. 1 and 6H-1 wells............................................................................. 7-26

Table 7-10. Target pressures for simulated in-situ conditions...................................... 7-26

Table 7-11. Compressibilities determined from hydrostatic compression for samples from the

Anasazi Nos. 1 and 6H-1 wells.

Table 7-12. Quasi-static mechanical properties determined from triaxial compression for samples from the Anasazi Nos. 1 and 6H-1 wells. .................................................. 7-27

Table 7-13. Parameters determined during uniaxial strain/pore pressure

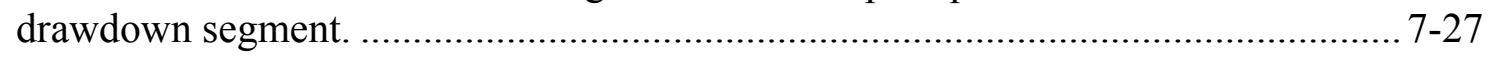

Table 8-1. Analysis of gravity drainage behavior................................................... 8-5

Table 8-2. Production/injection data for $\mathrm{CO}_{2}$ flood, Anasazi field................................. 8-16

Table 9-1. Reserve and recovery determinations......................................................... 9-7 


\section{ABSTRACT}

The Paradox Basin of Utah, Colorado, and Arizona contains nearly 100 small oil fields producing from shallow-shelf carbonate buildups or mounds within the Desert Creek zone of the Pennsylvanian (Desmoinesian) Paradox Formation. These fields typically have one to four wells with primary production ranging from 700,000 to 2,000,000 barrels $\left(111,300-318,000 \mathrm{~m}^{3}\right)$ of oil per field at a 15 to 20 percent recovery rate.

Five fields in southeastern Utah were evaluated for waterflood or carbon-dioxide $\left(\mathrm{CO}_{2}\right)$ miscible flood projects based upon geological characterization and reservoir modeling. Geological characterization on a local scale focused on reservoir heterogeneity, quality, and lateral continuity as well as possible compartmentalization within each of the five project fields.

The Desert Creek zone includes three generalized facies belts: (1) open-marine, (2) shallow-shelf and shelf-margin, and (3) intra-shelf, salinity-restricted facies. These deposits have modern analogs near the coasts of the Bahamas, Florida, and Australia, respectively, and outcrop analogs along the San Juan River of southeastern Utah. The analogs display reservoir heterogeneity, flow barriers and baffles, and lithofacies geometry observed in the fields; thus, these properties were incorporated in the reservoir simulation models.

Productive carbonate buildups consist of three types: (1) phylloid algal, (2) coralline algal, and (3) bryozoan. Phylloid-algal buildups have a mound-core interval and a supra-mound interval. Hydrocarbons are stratigraphically trapped in porous and permeable lithotypes within the mound-core intervals of the lower part of the buildups and the more heterogeneous supramound intervals. To adequately represent the observed spatial heterogeneities in reservoir properties, the phylloid-algal bafflestones of the mound-core interval and the dolomites of the overlying supra-mound interval were subdivided into ten architecturally distinct lithotypes, each of which exhibits a characteristic set of reservoir properties obtained from outcrop analogs, cores, and geophysical logs.

The Anasazi and Runway fields were selected for geostatistical modeling and reservoir compositional simulations. Models and simulations incorporated variations in carbonate lithotypes, porosity, and permeability to accurately predict reservoir responses. History matches tied previous production and reservoir pressure histories so that future reservoir performances could be confidently predicted.

The simulation studies showed that despite most of the production being from the mound-core intervals, there were no corresponding decreases in the oil in place in these intervals. This behavior indicates gravity drainage of oil from the supra-mound intervals into the lower mound-core intervals from which the producing wells' major share of production arises. The key to increasing ultimate recovery from these fields (and similar fields in the basin) is to design either waterflood or $\mathrm{CO}_{2}$-miscible flood projects capable of forcing oil from high-storage-capacity but low-recovery supra-mound units into the high-recovery mound-core units.

Simulation of Anasazi field shows that a $\mathrm{CO}_{2}$ flood is technically superior to a waterflood and economically feasible. For Anasazi field, an optimized $\mathrm{CO}_{2}$ flood is predicted to recover a total 4.21 million barrels $\left(0.67\right.$ million $\left.\mathrm{m}^{3}\right)$ of oil representing in excess of 89 percent of the original oil in place. For Runway field, the best $\mathrm{CO}_{2}$ flood is predicted to recover a total of 2.4 million barrels $\left(0.38\right.$ million $\left.\mathrm{m}^{3}\right)$ of oil representing 71 percent of the original oil in place. If the $\mathrm{CO}_{2}$ flood performed as predicted, it is a financially robust process for increasing the reserves in the many small fields in the Paradox Basin. The results can be applied to other fields in the Rocky Mountain region, the Michigan and Illinois Basins, and the Midcontinent. 


\section{EXECUTIVE SUMMARY}

The Paradox Basin of Utah, Colorado, and Arizona contains nearly 100 small oil fields producing from carbonate buildups or mounds within the Pennsylvanian (Desmoinesian) Paradox Formation. These fields typically have one to four wells with primary production ranging from 700,000 to $2,000,000$ barrels $\left(111,300-318,000 \mathrm{~m}^{3}\right)$ of oil per field at a 15 to 20 percent recovery rate. At least 200 million barrels $\left(31,800,000 \mathrm{~m}^{3}\right)$ of oil is at risk of being unrecovered in these small fields because of inefficient recovery practices and undrained heterogeneous reservoirs. Five fields (Anasazi, Mule, Blue Hogan, Heron North, and Runway) within the Navajo Nation of southeastern Utah were evaluated for waterflood or carbon-dioxide $\left(\mathrm{CO}_{2}\right)$-miscible flood projects based upon geological characterization and reservoir modeling. The results can be applied to other fields in the Paradox Basin and the Rocky Mountain region, the Michigan and Illinois Basins, and the Midcontinent.

The oil production in the circum-Aneth area of the Paradox Basin is from shallow-shelf carbonate buildups in the Desert Creek zone of the Paradox Formation. These deposits have modern analogues near the coasts of Florida and Australia, and the Bahamas. Understanding these facies and depositional patterns within the basin and their modern analogs helped to: (1) estimate reservoir heterogeneity and capacity, and (2) identify areas that have the greatest petroleum potential. Outcrops of the Paradox Formation Ismay zone along the San Juan River of southeastern Utah, provide a small-scale analogue of the reservoir heterogeneity, flow barriers and baffles, and lithofacies geometry observed in the fields. This analogue includes: (1) a phylloid-algal mound, (2) a "reef wall," and (3) a carbonate detrital wedge and fan. These characteristics were incorporated in the reservoir simulation models.

Three generalized facies belts are present in the Desert Creek zone of the Paradox Formation: (1) open-marine, (2) shallow-shelf and shelf-margin, and (3) intra-shelf, salinityrestricted facies. The shallow-shelf and shelf-margin facies belt, where all five project fields are located, includes shallow-shelf carbonate buildups, platform-margin calcarenites, and platform-interior carbonate muds and sands. Productive carbonate buildups can be divided into three types: (1) phylloid algal (further subdivided into shelter, mud-rich, and solution-breccia facies), (2) coralline algal, and (3) bryozoan. Hydrocarbons are stratigraphically trapped in porous and permeable lithotypes within the mound-core intervals, particularly phylloid-algal buildup facies, and the heterogeneous supra-mound intervals of the Desert Creek carbonate buildups. The platform-margin calcarenite facies are located along the margins of the larger shallow shelf or the rims of phylloid-algal buildup complexes. Mapping indicates a relatively untested belt of shallow-shelf, calcarenite carbonate deposits.

Geological characterization on a local scale focused on reservoir heterogeneity, quality, and lateral continuity as well as possible compartmentalization within each of the five project fields. This study utilized representative core and modern geophysical logs to characterize and grade each of the five fields for suitability of enhanced recovery projects. The typical vertical sequence or cycle of lithofacies from each field, as determined from conventional core, was tied to its corresponding log response.

Structure contour maps on the top of the Desert Creek zone of the Paradox Formation and gross Desert Creek interval isopach maps were constructed for the project fields. These maps were combined to show carbonate buildup trends, define limits of field potential, and indicate possible combination structural and stratigraphic traps. Basic reservoir parameters and production histories for each field were also compiled and summarized. 
The diagenetic fabrics and porosity types found in the various hydrocarbon-bearing rocks of each field can be an indicator of reservoir flow capacity, storage capacity, and potential for water- and/or $\mathrm{CO}_{2}$-flooding. Diagenetic histories of the various Desert Creek reservoirs were determined from more than 50 thin sections of representative samples selected from the conventional cores of each field for petrographic description and to grade each for suitability of enhanced recovery projects.

Isochron maps, based on new seismic data, indicate Mule field is a lenticular, north to northeast-trending, linear mound with additional reservoir potential on strike to the northeast of the most productive well in the field, the Mule No. 31-M. Harken Southwest Corporation, the field operator, determined the most economical way to penetrate a significant portion of this potential mound buildup was to re-enter the Mule No. 31-K-1 (N) well and drill horizontally in a northwest direction. The Mule No. 31 K-1 sidetrack, with a horizontal displacement of 939 feet $(286 \mathrm{~m})$, was the first horizontal test of a small algal buildup in the Paradox Basin. Some zones of intercrystalline porosity in dolomites and black residual oil staining observed in the cuttings lead the operator to attempt an open-hole well completion which finalized at a rate of 149 barrels $\left(24 \mathrm{~m}^{3}\right)$ of oil and 223 barrels $\left(35 \mathrm{~m}^{3}\right)$ of water per day, respectively.

Procedures for quantitatively characterizing the Anasazi field reservoir were defined and the required data assembled from a variety of sources. To adequately represent the observed spatial heterogeneities in reservoir properties, the mound-core interval phylloid algal bafflestones and overlying supra-mound interval dolomites were subdivided into ten architecturally distinct lithotypes, each of which exhibits a characteristic set of reservoir properties. Geometries and patterns of spatial arrangement for these lithotypes have been inferred from the outcrop analogue studies and comparison with previous work in nearby Greater Aneth field. Reservoir properties and lithotype characterizations were obtained from cores and logs from the four Anasazi wells. Model constraints on lateral variation in average reservoir porosity and permeability were imposed by data obtained from six interpreted twodimensional seismic lines and well-test results. The initial three-dimensional reservoir model consisted of 50, 2-foot (0.6-m) layers on a 30 x 50-cell (380 acre [154 ha]) geographic grid, comprising a total of 75,000 grid blocks.

The reservoir-engineering component of the work included analysis of production data and well tests, comprehensive laboratory programs, and preliminary mechanistic reservoir simulation studies. Well-test analysis indicated that dual-property models should be used to interpret the pressure response behavior of the Desert Creek zone. The laboratory work included gas-oil and oil-brine relative permeability and capillary pressure measurements on new preserved cores. In addition, reservoir rock wettability measurements were completed. Rock compressibility measurement on both supra-mound (dolomite) and mound-core (limestone) samples provided data to more reliably model the liquid expansion phase of Paradox Basin reservoir production.

A comprehensive fluid property characterization program was completed. This work included a suite of carbon dioxide swelling tests using Anasazi field crude oil. Data from this set of experiments, in conjunction with black oil pressure-volume-temperature data obtained on original fluid samples, were used to calibrate an equation of state for compositional simulation studies.

Mechanistic reservoir production performance simulation studies were also completed. To provide some initial insight into the basic production mechanism of the Anasazi reservoir, some simple one- and two-dimensional compositional simulation studies were conducted prior 
to developing final reservoir description models and the final three-dimensional simulation study. The results showed that even though most of the production comes from the mound-core interval, there is not a corresponding decrease in the oil in place in the mound-core interval. This behavior clearly indicates gravity drainage of oil from the supra-mound interval into the lower mound-core interval from which the producing wells' major share of production arises.

The Anasazi and Runway fields were selected for geostatistical modeling and reservoir simulations. The key to increasing ultimate recovery from these fields (and similar fields in the basin) is to design either waterflood or $\mathrm{CO}_{2}$-miscible flood projects capable of forcing oil from high-storage-capacity, but low-recovery, supra-mound units into the high-recovery, mound-core units. Statistical modeling included architectural, porosity, and permeability 15-layer models. The results were used in reservoir simulations to test and design waterflood or $\mathrm{CO}_{2}$-miscible flood projects.

The reservoir analysis for the Anasazi field required a field-scale reservoir simulator. Enhanced recovery through $\mathrm{CO}_{2}$ flooding and waterflooding were evaluated using compositional simulations. Variations in carbonate lithotypes, porosity, and permeability were incorporated into the simulation in order to accurately predict reservoir responses. History matches were made by tying to previous production and reservoir pressure history so that future reservoir performances could be confidently predicted.

Simulation of Anasazi field has shown that a $\mathrm{CO}_{2}$ flood is technically superior to a waterflood and economically feasible. For Anasazi field, an optimized $\mathrm{CO}_{2}$ flood is predicted to recover a total 4.21 million barrels $\left(0.67\right.$ million $\left.\mathrm{m}^{3}\right)$ of oil representing in excess of 89 percent of the original oil in place. For Runway field, the best $\mathrm{CO}_{2}$ flood is predicted to recover a total of 2.4 million barrels $\left(0.38\right.$ million $\left.\mathrm{m}^{3}\right)$ of oil representing 71 percent of the original oil in place. If the $\mathrm{CO}_{2}$ flood performed as predicted, it is a financially robust process for increasing the reserves in the many small fields in the Paradox Basin. Unfortunately, the project was terminated without the benefit of the field pilot-flood demonstration due to a variety of problems between the operator and the Navajo Nation, low oil prices, and a lack of $\mathrm{CO}_{2}$. 


\section{ACKNOWLEDGEMENTS}

\section{Project Financial Support}

This research was performed under the Class II Oil Program of the U.S. Department of Energy (DOE), National Petroleum Technology Office, Tulsa, Oklahoma, contract number DEFC22-95BC14988. The Contracting Officer's Representative/Project Managers were Rhonda P. Lindsey, Gary D. Walker, and Daniel Ferguson. Additional funding was provided by Harken Southwest Corporation, Houston, Texas, and the Utah Office of Energy Services, Salt Lake City, Utah, Jeff Burks, past Director and Thomas Brill, Director.

\section{Project Contributors}

\section{Principal Investigators}

M.Lee Allison, Utah Geological Survey, Salt Lake City, Utah (now with the Kansas Geological Survey, Lawence, Kansas)

Thomas C. Chidsey, Jr., Utah Geological Survey, Salt Lake City, Utah

\section{Program Manager}

Thomas C. Chidsey, Jr., Utah Geological Survey, Salt Lake City, Utah

\section{Financial Officers}

Werner Haidenthaller (now with the Utah Department of Workforce Services), John Kingsley, Dan Kelly, Utah Geological Survey, Salt Lake City, Utah

Bruce N. Huff, Harken Southwest Corp., Houston, Texas

\section{Task Contributing Scientists and Organizations}

Roger L. Bon, Thomas C. Chidsey, Jr., Michael D. Laine, Kevin McClure, Craig D. Morgan, Douglas A. Sprinkel, Kimberly A. Waite, Utah Geological Survey, Salt Lake City, Utah

Marshall Watson (now independent, Midland, Texas), Wilson Groen, Kris Hartmann, Rich Cottle, David Gibbs, Joe Clarke, Harken Southwest Corp., Houston, Texas

Wil E. Culham, Douglas M. Lorenz (now with ChevronTexaco, Houston, Texas), REGA Inc., Houston, Texas

David E. Eby, Eby Petrography \& Consulting, Inc., Littleton, Colorado

Lisë Brinton, LithoLogic, Inc., Englewood, Colorado 
The following individuals and organizations provided valuable advice and data: Herb Mosca, Bligh Petroleum, Inc., Dallas, Texas; Peter G. Moreland, Geologic Consultant, Denver, Colorado; and John Johnson (formerly with Minerals Department, Navajo Nation, Window Rock, Arizona). Brenda Kirkland George and Jonas Gournay of the University of Texas, Austin, Texes, described core from the Anasazi No. 1 well. Bradley G. Hill of the Utah Division of Oil, Gas and Mining, Salt Lake City, Utah, provided project base maps and other services.

Utah Geological Survey Petroleum News was edited by Roger Bon and Tim Madden. The project Internet Homepage was managed by Christine Wilkerson. Jim Parker, Sharon Hamre, Vicky Clarke, Cheryl Gustin, Kevin McClure, Michele Hoskins, Carolyn Olsen, Ron Neeley, and Dan Aubrey (Utah Geological Survey) drafted figures, designed displays, photographed core, and assembled reports. Desktop publishing was by Cheryl Gustin, Utah Geological Survey.

This report, or portions of it, were reviewed by: Bryce Tripp, David Tabet, Mike Hylland, and Kimm Harty, Utah Geological Survey; Rhonda P. Lindsey, Gary D. Walker, Daniel Ferguson, National Petroleum Technology Office, U.S. Department of Energy, Tulsa, Oklahoma; and Viola Rawn-Schatzinger of BDM-Oklahoma, Inc., Tulsa, Oklahoma. 


\title{
CHAPTER I INTRODUCTION
}

\author{
Thomas C. Chidsey, Jr. \\ Utah Geological Survey
}

Over 400 million barrels $\left(63,600,000 \mathrm{~m}^{3}\right)$ of oil have been produced from shallow-shelf carbonate reservoirs in the Pennsylvanian (Desmoinesian) Paradox Formation in the Paradox Basin of Utah, Colorado, and Arizona. With the exception of the giant Greater Aneth field, nearly 100 oil fields in the basin typically contain 2 to 10 million barrels $(318,000-1,590,000$ $\mathrm{m}^{3}$ ) of original oil in place per field. To date, none of these small fields have been the site of tertiary carbon dioxide $\left(\mathrm{CO}_{2}\right)$ flood recovery techniques used in large carbonate reservoirs. Most of these fields are characterized by extremely high initial production rates followed by a very short production life (primary), and hence early abandonment. At least 200 million barrels $\left(31,800,000 \mathrm{~m}^{3}\right)$ of oil is at risk of being left behind in these small fields because of inefficient recovery practices and undrained heterogeneous reservoirs. The purpose of this multi-year project is to enhance domestic petroleum production by reservoir characterization, modeling, and simulation, and field demonstration of an advanced-oil-recovery technology in the Paradox Basin.

The benefits expected from the project are: (1) increasing recoverable reserves by identifying untapped compartments created by reservoir heterogeneity, (2) increasing deliverability through a carbon-dioxide- $\left(\mathrm{CO}_{2}-\right)$ miscible flood which exploits the reservoir along optimal fluid-flow paths, (3) identifying reservoir trends for field extension drilling and stimulating exploration in Paradox basin fairways, (4) preventing premature abandonment of numerous small fields, (5) reducing development costs by more closely delineating minimum field size and other parameters necessary to a successful flood, (6) allowing limited energy investment dollars to be used more productively, and (7) increasing royalty income to the Navajo Nation; Federal, State, and local governments; and fee owners. These benefits also apply to other areas in the Rocky Mountain region, the Michigan and Illinois Basins, and the Midcontinent.

The geological and reservoir characteristics of five fields on the Navajo Nation of southeastern Utah (figure 1-1), that produce oil and gas from the Desert Creek zone of the Paradox Formation, were quantitatively determined by a multidisciplinary team. Anasazi field was chosen as the best candidate for a pilot $\mathrm{CO}_{2}$-flood demonstration project after reservoir simulations were completed on both the Anasazi and Runway fields. To evaluate these fields as models for other shallow-shelf carbonate reservoirs, the Utah Geological Survey (UGS), Harken Southwest Corporation, Eby Petrography \& Consulting Inc., and REGA Inc. entered into a cooperative agreement with the U.S. Department of Energy (DOE) as part of its Class II Oil program. 


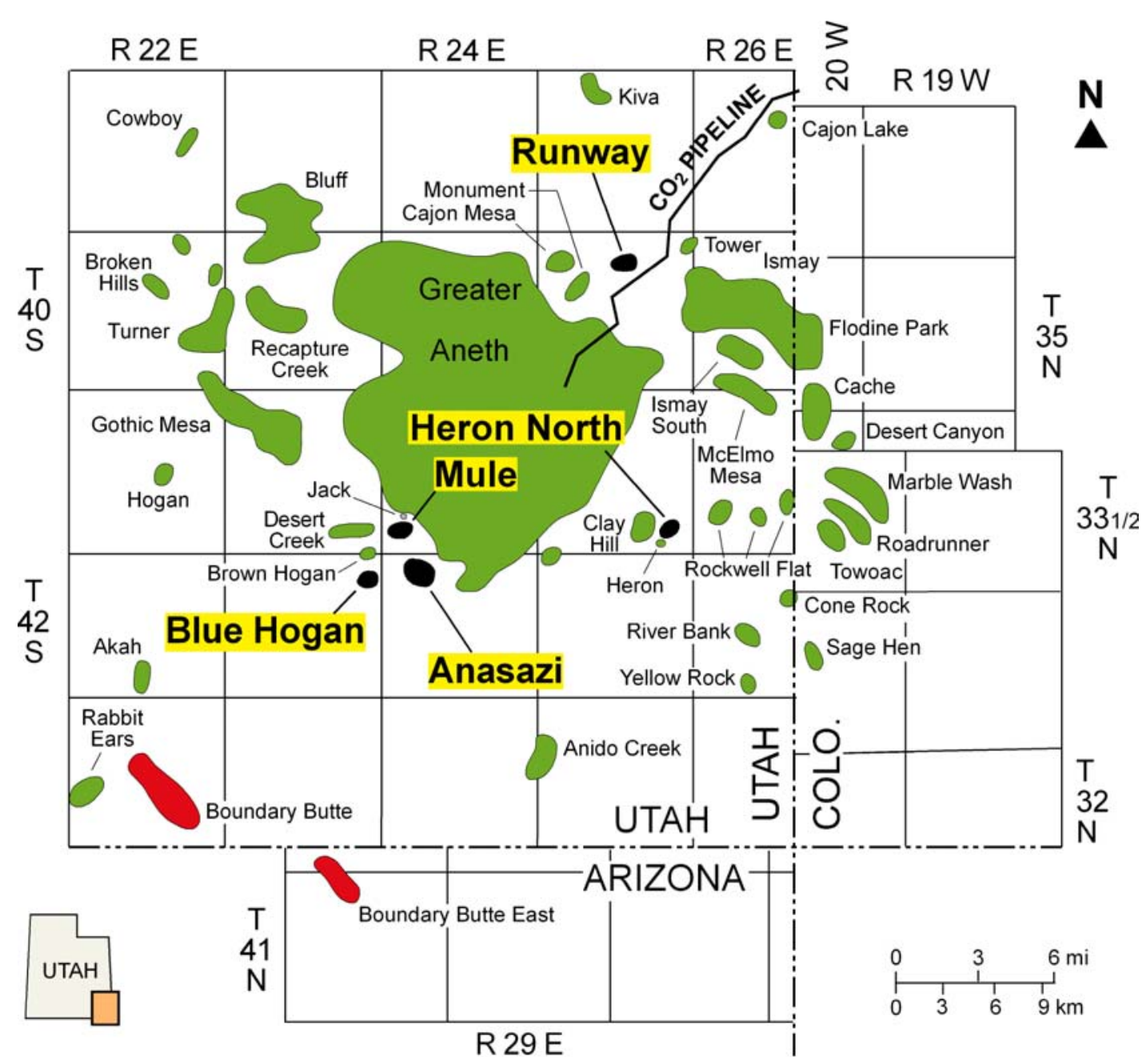

Figure 1-1. Location of the five project fields (dark shaded areas with names in bold type) on the Navajo Nation, San Juan County, southeastern Utah.

A two-phase approach was used to help increase production and reserves from the shallow-shelf carbonate reservoirs in the Paradox Basin. Phase I was the geological and reservoir characterization of the five small fields. Work completed during this phase of the project included:

(a) field data collection and compilation,

(b) determining regional facies and untested trends,

(c) evaluating the results of outcrop data collected from the Paradox Formation along the San Juan River which provide production-scale analogues of reservoirfacies characteristics, geometry, and distribution,

(d) determining geological setting and facies characterization of carbonate buildups, 
(e) analyzing the sequence stratigraphic framework to define and predict reservoir development and continuity,

(f) acquiring new seismic data and drilling both vertical and horizontal development wells,

(g) extensive reservoir mapping,

(h) determination of diagenetic fabrics and porosity types found in the various hydrocarbon bearing rocks of each field,

(i) field-scale geologic analysis to focus on the reservoir heterogeneity, quality, and lateral continuity versus compartmentalization,

(j) various laboratory tests and analogies to large-scale waterfloods $/ \mathrm{CO}_{2}$ floods,

(k) reservoir geostatistical modeling,

(1) history matching and reservoir $\mathrm{CO}_{2}$-flood and waterflood simulations,

(m) field reserves and secondary/tertiary recovery determination,

(n) determining the economic viability of secondary/tertiary recovery options,

(o) economic assessments of $\mathrm{CO}_{2}$ floods for Anasazi and Runway fields (figure 1-1), and

(p) recommendation of plans for pilot flood implementation and production scenarios for Phase II, the field demonstration project.

Phase II was to be a demonstration project on Anasazi field, which was selected from the characterization study, using a $\mathrm{CO}_{2}$-miscible flood. This technique was identified as having the greatest potential for increased well productivity and ultimate recovery. Based on the geologic characterization study, reservoir performance predictions, and the associated economic assessment of implementing a $\mathrm{CO}_{2}$ flood in the Anasazi field, an optimized $\mathrm{CO}_{2}$ flood was predicted to recover 4.21 million barrels $\left(0.67\right.$ million $\left.\mathrm{m}^{3}\right)$ of oil. This represents an increase of 1.65 million barrels $\left(0.26\right.$ million $\left.\mathrm{m}^{3}\right)$ of oil over predicted primary depletion recovery. If the $\mathrm{CO}_{2}$ flood performs as predicted, it is a financially robust process for increasing the reserves of the Anasazi field and similar small fields in the basin.

The UGS and DOE elected to terminate the project without the benefit of the field pilotflood demonstration due to a variety of problems the operator was having with the Navajo Nation, low oil prices, and a lack of $\mathrm{CO}_{2}$ availability. This report summarizes the research, data, analyses, and results of the project, thus providing the tools for a successful $\mathrm{CO}_{2}$ pilot flood to occur in the small reservoirs found in the Paradox Basin and other shallow-shelf carbonate deposits. 


\title{
CHAPTER II \\ REGIONAL FACIES EVALUATION
}

\author{
Thomas C. Chidsey, Jr., Utah Geological Survey \\ and
}

David E. Eby, Eby Petrography \& Consulting, Inc.

\section{Introduction}

Establishment of the general regional facies belts and stratigraphic patterns within the shallow-shelf carbonate Desert Creek zone of the Paradox Formation for the southern Paradox Basin is critical to: (1) understanding reservoir heterogeneity and capacity of the five fields evaluated for the pilot demonstration and (2) defining areas in the basin that have the greatest petroleum potential. Generalized regional facies belts for the Desert Creek zone (figure 2-1) were mapped utilizing more than 30 conventional cores, rotary sidewall cores, cuttings descriptions, and geophysical log interpretations.

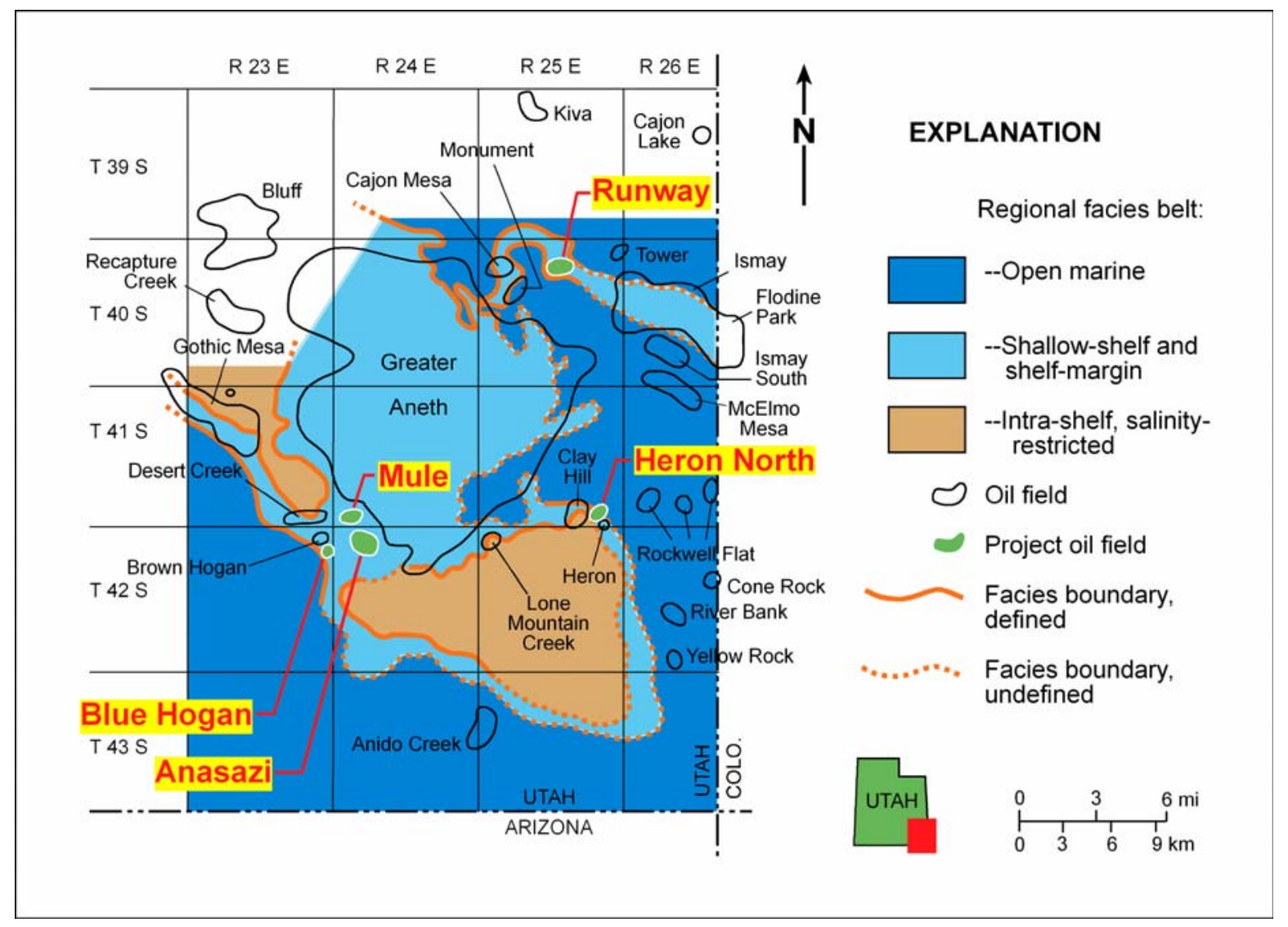

Figure 2-1. Generalized regional facies belts for Desert Creek zone, Pennsylvanian Paradox Formation, southeastern San Juan County, Utah. 


\section{Paleogeographic Setting}

The Paradox Basin was a structural and depositional trough associated with the Pennsylvanian-age Ancestral Rocky Mountains. The subsiding basin developed a shallowwater carbonate shelf that locally contained carbonate buildups along its south and southwest margins. These carbonate buildups, and the material shed from their flanks, formed petroleum traps where reservoir-quality porosity and permeability have developed.

During Pennsylvanian time, the Paradox Basin was in subtropical, dry climatic conditions along the trade-wind belt, $10^{\circ}$ to $20^{\circ}$ north of the paleo-equator. Prevailing winds were from present day north (Peterson and Hite, 1969; Heckel, 1977; Parrish, 1982). Openmarine waters flowed across the shallow cratonic shelf into the basin during transgressive periods. There are four postulated normal marine access ways into the Paradox Basin. The Cabezon accessway, which was located to the southeast, is generally accepted as the most likely normal marine-water conduit to maintain circulation on the shallow shelf (Fetzner, 1960; Ohlen and McIntyre, 1965; Hite, 1970).

Cyclicity in Paradox Basin deposition was primarily controlled by glacio-eustatic fluctuations. The shape of the sea-level curves reflects rapid marine transgressions (rapid melting of ice caps) and slow, interrupted regression (slow ice cap buildup) (Imbrie and Imbrie, 1980; Denton and Hughes, 1983; Heckel, 1986). Irregular patterns within the cycles are predicted to be a response to interference of orbital parameters (Imbrie and Imbrie, 1980). These cycles were also influenced by: (1) regional tectonic activity and basin subsidence (Baars, 1966; Baars and Stevenson, 1982), (2) proximity to basin margin and evaporites (Hite, 1960; Hite and Buckner, 1981), (3) climatic variation and episodic blockage of open marinewater conduits, and (4) fluctuations in water depth and water energy (Peterson and Ohlen, 1963; Peterson, 1966; Hite and Buckner, 1981; Heckel, 1983).

\section{Generalized Regional Facies Belts}

Three, generalized, regional facies belts are identified (figures 2-1 and 2-2): (1) openmarine, (2) shallow-shelf and shelf-margin, and (3) intra-shelf, salinity-restricted facies. The open-marine facies belt includes open-marine buildups (typically crinoid-rich mounds), openmarine crinoidal- and brachiopod-bearing carbonate muds, euxinic black shales, wall complexes, and detrital fans. Open-marine facies were deposited at water depths between 45 and 120 feet $(14-37 \mathrm{~m})$. This facies belt is the most extensive and surrounds the shallow-shelf and shelf-margin facies belt.

The shallow-shelf and shelf-margin facies belt includes shallow-shelf buildups (phylloid algal, coralline algal, bryozoan, and marine-cemented buildups [mounds]), calcarenites (beach, dune, and stabilized grain flats), and platform-interior carbonate muds and sands. These facies were deposited at water depths between 0 and 40 feet $(0-12 \mathrm{~m})$. Karst characteristics are occasionally present over mounds. Tubular tempestites (burrows filled with coarse sand as a result of storm pumping) are found in some carbonate muds and sands. Most oil fields which produce from the Desert Creek zone of the Paradox Formation are located within this facies belt, including the giant Greater Aneth field (figures 2-1 and 2-2). 


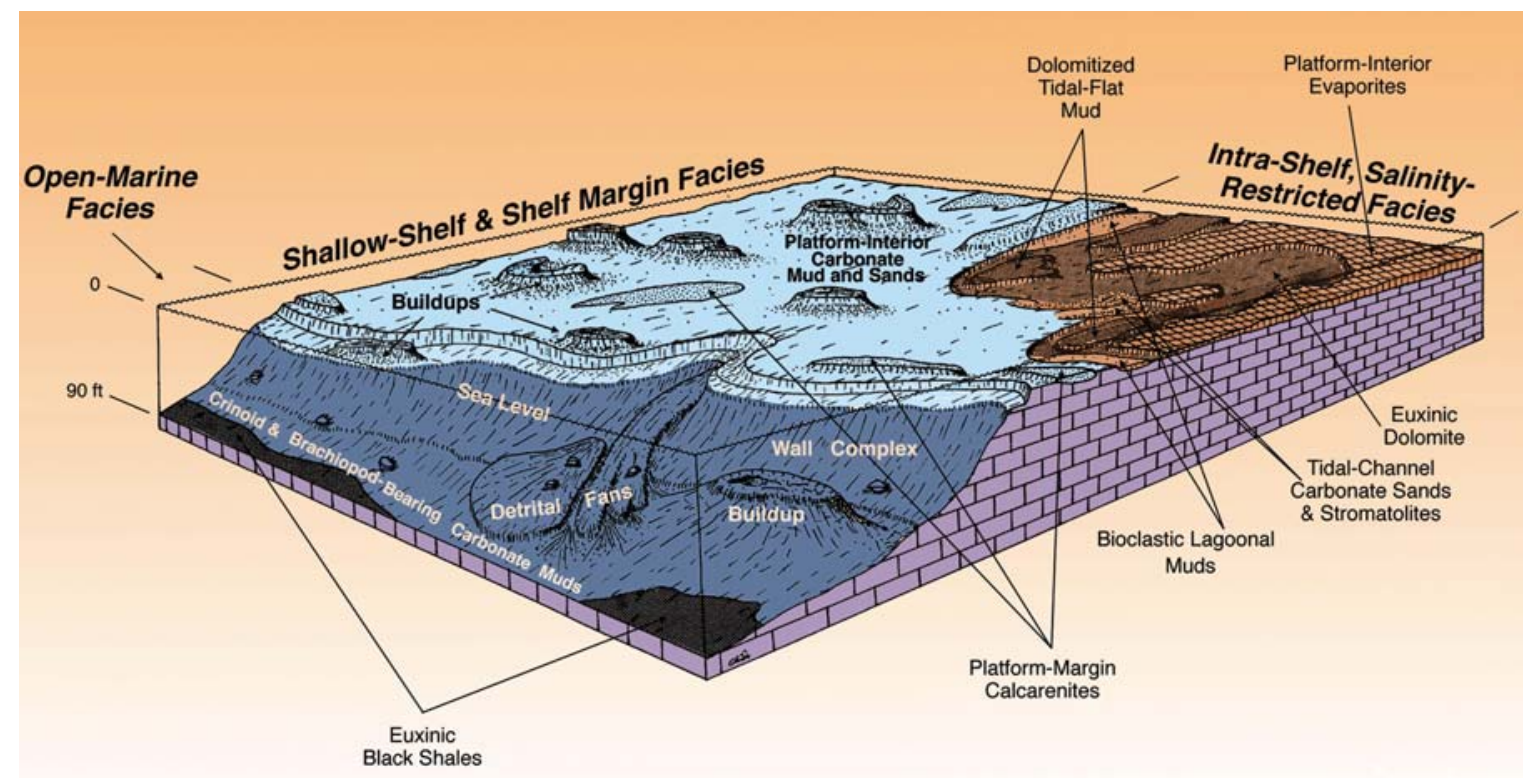

Figure 2-2. Block diagram displaying major facies within regional facies belts for the Desert Creek zone, Pennsylvanian Paradox Formation, southeastern San Juan County, Utah (from Chidsey, Eby, and Lorenz, 1996).

The intra-shelf, salinity-restricted facies belt represents small subbasins within the shallow-shelf and shelf-margin facies belt. The water had slightly elevated salinity compared to the other facies belts. This facies belt includes platform-interior evaporites, dolomitized tidalflat muds, bioclastic lagoonal muds, tidal-channel carbonate sands and stromatolites, and euxinic dolomites. These facies were deposited at water depths between 20 and 45 feet (6-14 $\mathrm{m})$. Euxinic dolomites often display karst characteristics. Two intra-shelf subbasins have been identified in the southeastern part of the Paradox Basin in Utah; each is separated from the open-marine facies belt by a fringe of the shallow-shelf and shelf-margin facies belt (figure 2$1)$.

\section{Potential Calcarenite Trend}

The shallow-shelf and shelf-margin facies belt includes shallow-shelf carbonate buildups, platform-margin calcarenites, and platform-interior carbonate muds and sands (described in detail later in Chapter 3). The platform-margin calcarenite facies are located along the margins of the larger shallow shelf or the rims of phylloid-algal buildup complexes. Mapping indicates a relatively untested belt of shallow-shelf, calcarenite carbonate deposits (figure 2-3). This narrow, but long, belt of calcarenite lithofacies is between the open marine lithofacies and the margins of intra-shelf, salinity-restricted lithofacies. Calcarenite buildups represent high-energy environments where shoals and/or islands developed as a result of regularly agitated, shallow-marine processes on the shelf (figure 2-4). Characteristic features of this lithofacies include: medium-scale cross-bedding; bar-type, carbonate sand-body morphologies; and algal meadows. Stabilized calcarenites occasionally developed subaerial features such as beach rock, hard grounds, and soil zones. Sediment deposition and modification probably occurred from 5 feet $(1.5 \mathrm{~m})$ above mean sea level to 20 feet $(6 \mathrm{~m})$ below sea level (Chidsey, Eby, and Lorenz, 1996; Chidsey, 1997). 


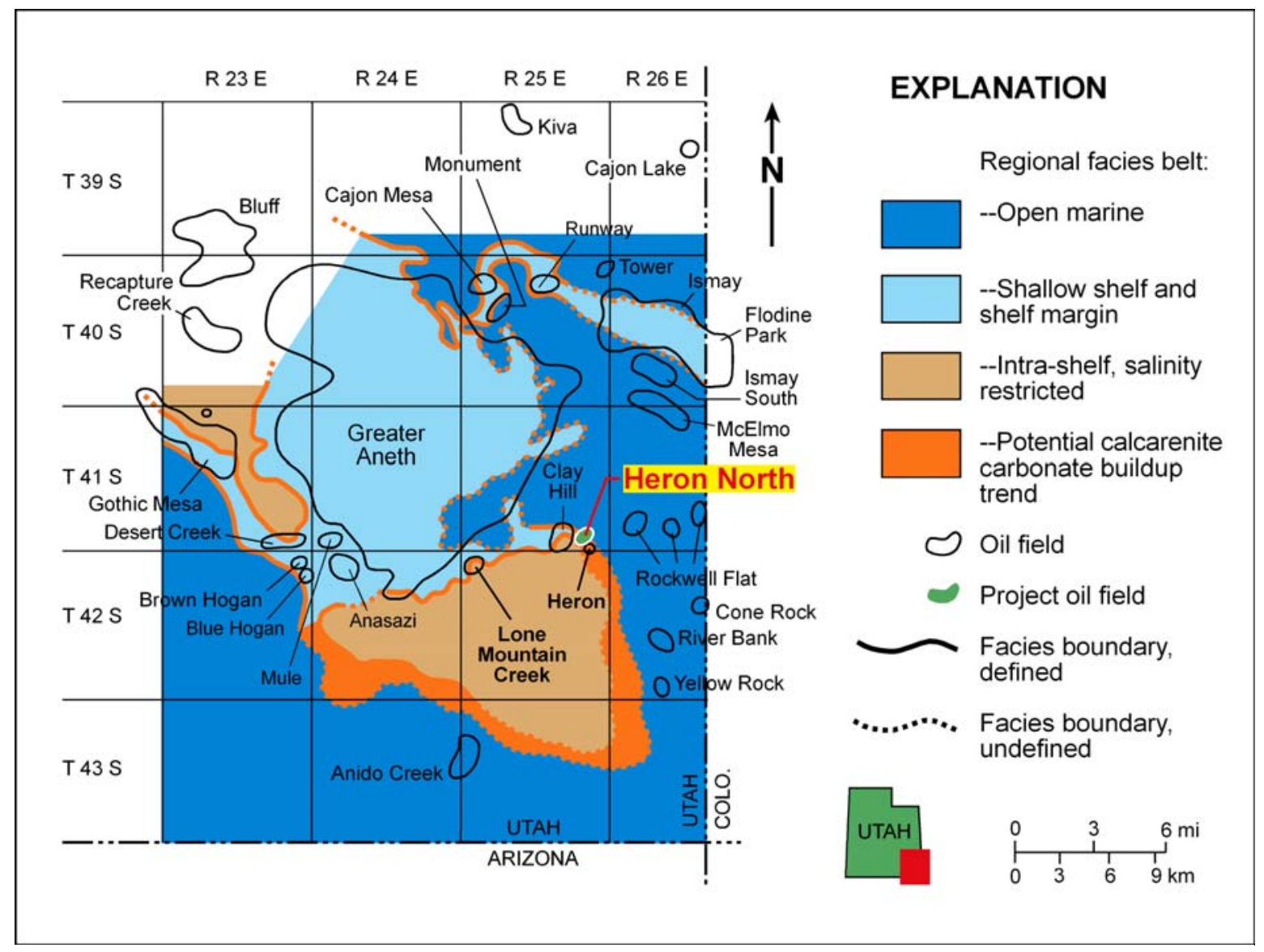

Figure 2-3. Potential calcarenite buildup trend (orange and hachured) within the regional facies belts of the Desert Creek zone, Paradox Formation, Navajo Nation, southeastern Utah.

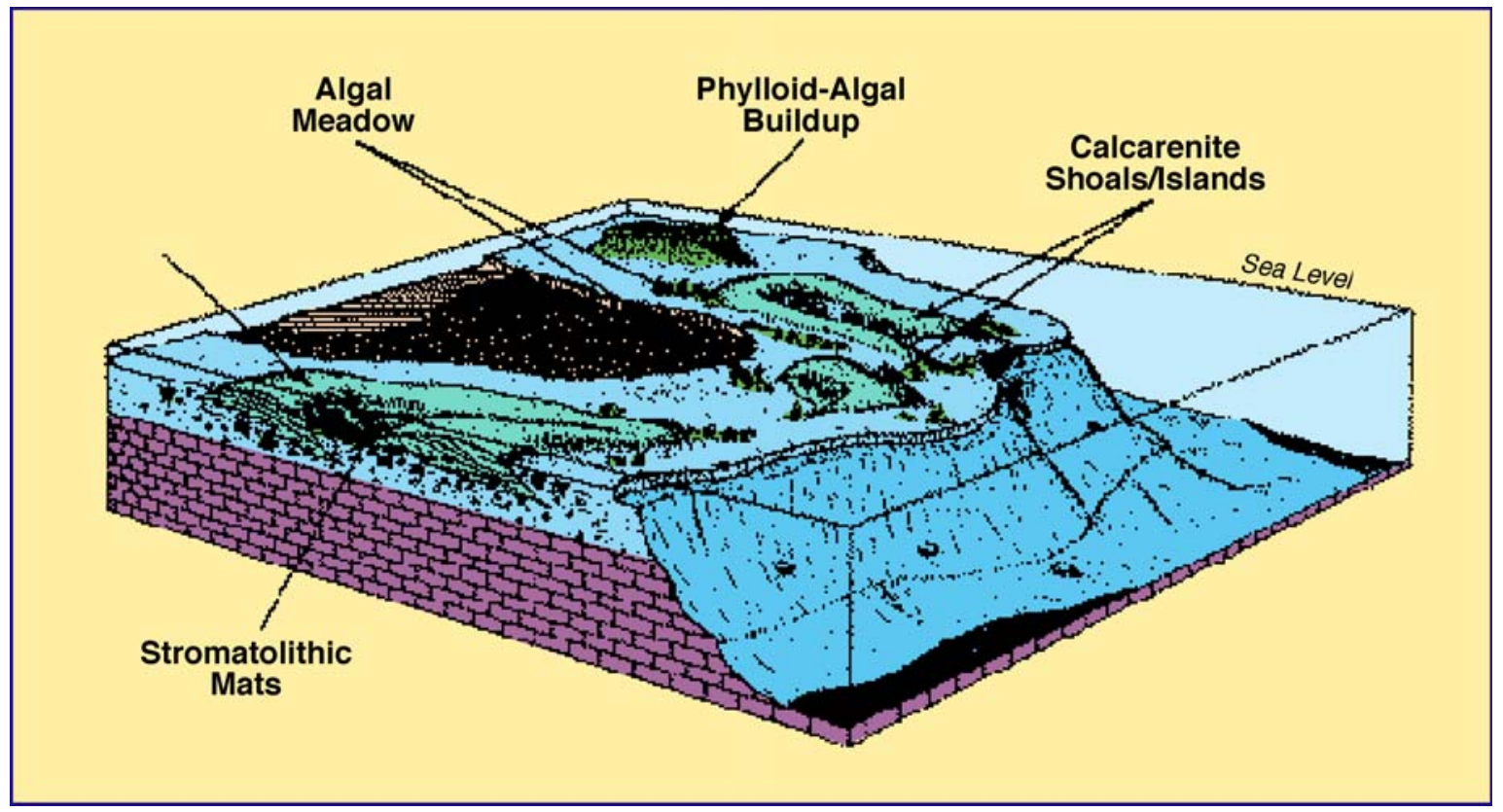

Figure 2-4. Depositional environments of the calcarenite facies along the narrow shelf margin between the open-marine and intra-shelf, salinity-restricted facies belts. 
The depositional fabrics of the calcarenite facies include grainstone and packstone. Rocks representing this facies typically contain the following diagnostic constituents: coated grains, hard pelloids, bioclastic grains, shell lags, and intraclasts.

Heron North field (figure 1-1) is an excellent example of the type of fields which potentially lie within this 20 -mile- (32-km-) long lithofacies belt. The field is a lenticular, northwest- to southeast-trending linear mound/beach complex, 0.8 miles $(1.3 \mathrm{~km})$ long and 0.5 miles $(0.8 \mathrm{~km})$ wide (Chidsey and others, 1996c). The reservoir consists of five units: (1) a basal, dolomitized, phylloid-algal (bafflestone) buildup, (2) an anhydrite-plugged, phylloidalgal (bafflestone) limestone buildup, (3) a fusilinid-bearing, lime-wackestone interval, (4) a dolomitized packstone interval with anhydrite nodules, and (5) a porous (15 percent), sucrosic, dolomitized grainstone and packstone interval. This last unit is the main reservoir, and consists of alternating 2- to 4- $(0.6-1.2-\mathrm{m}) \mathrm{ft}$-thick packages of uniform beach calcarenite and poorly sorted foreshore and storm-lag rudstone or breccia deposits.

These types of traps have both negative and positive characteristics for hydrocarbon production. Negative characteristics include: (1) small reservoir size and storage capacity, (2) poor definition on seismic records, (3) limited distribution, (4) common bitumen plugging, and (5) rapid production declines. Positive characteristics include: (1) excellent overall reservoir properties, (2) a common association with phylloid-algal buildups, (3) good potential for water/ $\mathrm{CO}_{2}$ floods, and (4) an extensive untested trend (Chidsey and Eby, 1997).

\section{Study Results}

Mounds, tidal-channel carbonate sands, and other features often appear promising on seismic records. However, if these carbonate buildups are located within the open-marine and intra-shelf, salinity-restricted facies belts, the reservoir quality is typically poor. Porosity and permeability development, if present, is limited or plugged with anhydrite in these respective facies belts. Mounds and calcarenites in the shallow-shelf and shelf-margin facies belt can have excellent reservoir properties (and untested exporation potential in the case of calcarenite facies); all five project fields are located within this facies belt. 


\title{
CHAPTER III \\ GEOLOGICAL CHARACTERIZATION OF PROJECT FIELDS, NAVAJO NATION, SAN JUAN COUNTY, UTAH
}

\author{
Thomas C. Chidsey, Jr. and Kevin McClure; Utah Geological Survey \\ Marshall Watson, Wilson Groen, and Kris Hartmann; Harken Southwest Corp. \\ and \\ David E. Eby; Eby Petrography \& Consulting, Inc.
}

\section{Introduction}

The five Paradox Basin fields evaluated in Phase I of the project were Runway, Heron North, Anasazi, Mule, and Blue Hogan, all located within the Navajo Nation of southeast Utah (figure 1-1). They are five of several satellite carbonate mounds around the giant Greater Aneth field. This evaluation included data collection, core analysis and description, reservoir mapping, and drilling new development wells.

Eby and others (1993) identified from core, five different types of carbonate buildups or mounds in the Desert Creek zone of the Paradox Formation: (1) crinoid/sponge mounds, (2) coralline-algal "reef" mounds, (3) bryozoan-dominated mounds, (4) phylloid-algal mounds, and (5) bioclastic calcarenite "beach" mounds. The controls on the development of each mound type were water depth, prevailing wave energy, and paleostructural position. Examination of core from the five project fields shows that three mound types are present (table 3-1), making the project fields good representatives of Desert Creek zone reservoirs. The geological and reservoir characterization of these fields and resulting models can applied to similar fields in the basin (and other basins as well) where data might be limited.

Table 3-1. Cumulative production of project fields in the Paradox Basin, San Juan County, Utah.

\begin{tabular}{|l|c|c|c|c|l|}
\hline \multirow{2}{*}{ Field } & $\begin{array}{c}\text { Active } \\
\text { Wells }\end{array}$ & \multicolumn{3}{c|}{ Cumulative Production* } & \multirow{2}{*}{ Buildup Type } \\
\cline { 2 - 6 } & & Oil (bbls) & Gas (MCF) & Water (bbls) & \\
\hline Anasazi & 4 & $2,042,795$ & $1,801,085$ & 35,518 & Phylloid Algal \\
\hline Blue Hogan & 1 & 341,468 & 339,966 & 2,139 & Phylloid Algal \\
\hline Mule & 2 & 465,003 & 329,740 & 41,872 & Phylloid Algal \\
\hline Heron North & 1 & 206,446 & 328,713 & 36,437 & Bioclastic Calcarenite \\
\hline Runway & 3 & 832,382 & $2,859,509$ & 15,383 & $\begin{array}{l}\text { Bryozoan-dominated/ } \\
\text { Phylloid Algal }\end{array}$ \\
\hline
\end{tabular}

*As of January 1, 2002 (Utah Division of Oil, Gas and Mining, 2002). 


\section{Data Collection, Core Description, and Reservoir Mapping}

Reservoir data, cores and cuttings, geophysical logs, various reservoir maps, and other information from the project fields and regional exploratory wells were collected by the UGS. Well locations, production reports, completion tests, core analysis, formation tops, and other data were compiled and entered in a database developed by the UGS. This database, INTEGRAL, is a geologic-information database that links a diverse set of geologic data to records using Microsoft ${ }^{\circledR}$ Access software. The database is designed so that geological information, such as lithology, petrophysical analyses, or depositional environment can be exported to software programs to produce strip logs, lithofacies maps, various graphs, statistical models, and other types of presentations. The UGS acquired information for 52 project wells. Production data, basic core analyses, geophysical log types, and well cutting information for these project wells were entered into the UGS INTEGRAL database. In addition, completion test data and formation tops were also entered into the database for these wells.

Base maps and new isochron maps covering project fields were prepared, and cores were described from selected project wells with special emphasis on bounding surfaces of possible flow units. The core descriptions follow the guidelines of Bebout and Loucks (1984) which include: (1) basic porosity types, (2) mineral composition in percentage, (3) nature of contacts, (4) carbonate structures, (5) carbonate textures in percentage, (6) carbonate fabrics, (7) grain size (dolomite), (8) fractures, (9) color, (10) fossils, (11) cement, and (12) depositional environment. Carbonate fabrics were determined according to Dunham's (1962) and Embry and Klovan's (1971) classification schemes.

Geological characterization on a local scale focused on reservoir heterogeneity, quality, and lateral continuity as well as possible compartmentalization within each of the five project fields. This study utilized representative core and modern geophysical logs to characterize and grade each of the five fields for suitability of enhanced recovery projects.

The typical vertical sequence, or cycle of lithofacies, from each field, as determined from conventional core, was tied to its corresponding log response (figures 3-1 through 3-5). These sequences graphically include: (1) carbonate fabric, pore type, physical structures, texture, framework grains, and facies (as defined by Chidsey and others, 1996; Chidsey, 1997) described from core, (2) plotted porosity and permeability analysis from core plugs, and (3) gamma-ray and neutron-density curves from geophysical logs. The graphs were used for identifying reservoir and non-reservoir rock, determining potential units suitable for water- and/ or $\mathrm{CO}_{2}$-flood projects, and comparing field to non-field areas.

Structure contour maps on the top of the Desert Creek zone of the Paradox Formation and gross Desert Creek interval isopach maps were constructed for the Anasazi, Blue Hogan, Heron North, Mule, and Runway project fields, San Juan County, Utah (Chidsey, Eby, and others, 1996a-e). These maps were combined to show carbonate buildup trends, define limits of field potential, and indicate possible combination structural and stratigraphic traps (figures 3-6 through 3-10). Well names and total depths are given for project field wells. The maps indicate Desert Creek completions, completion attempts, and drill-stem tests and display the Desert Creek subsea top and gross thickness for each well. These maps incorporated correlations from all geophysical well logs in the areas, and regional Chimney Rock shale structure maps and gross Desert Creek isopach maps generated from closely spaced seismic lines. 


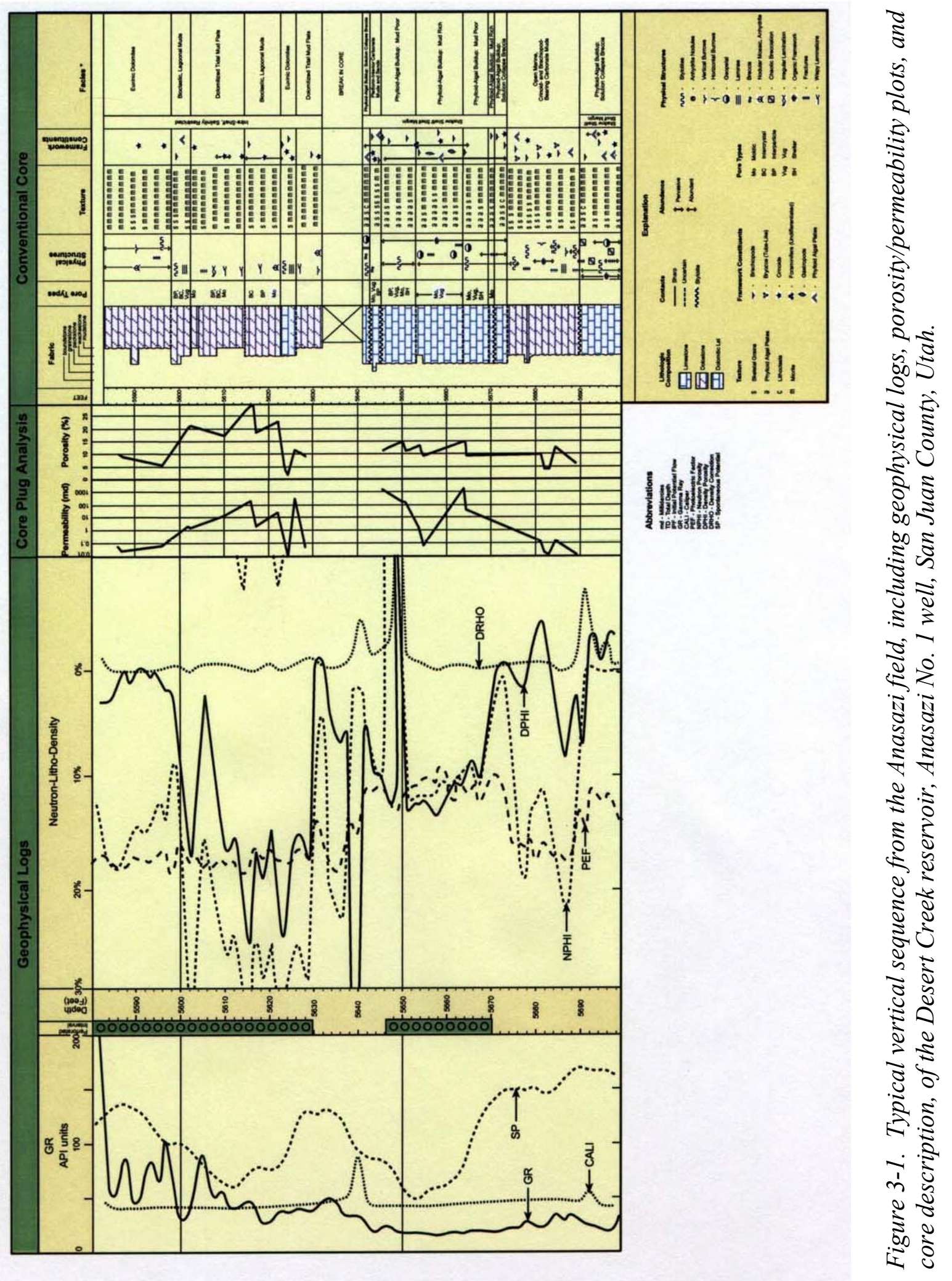




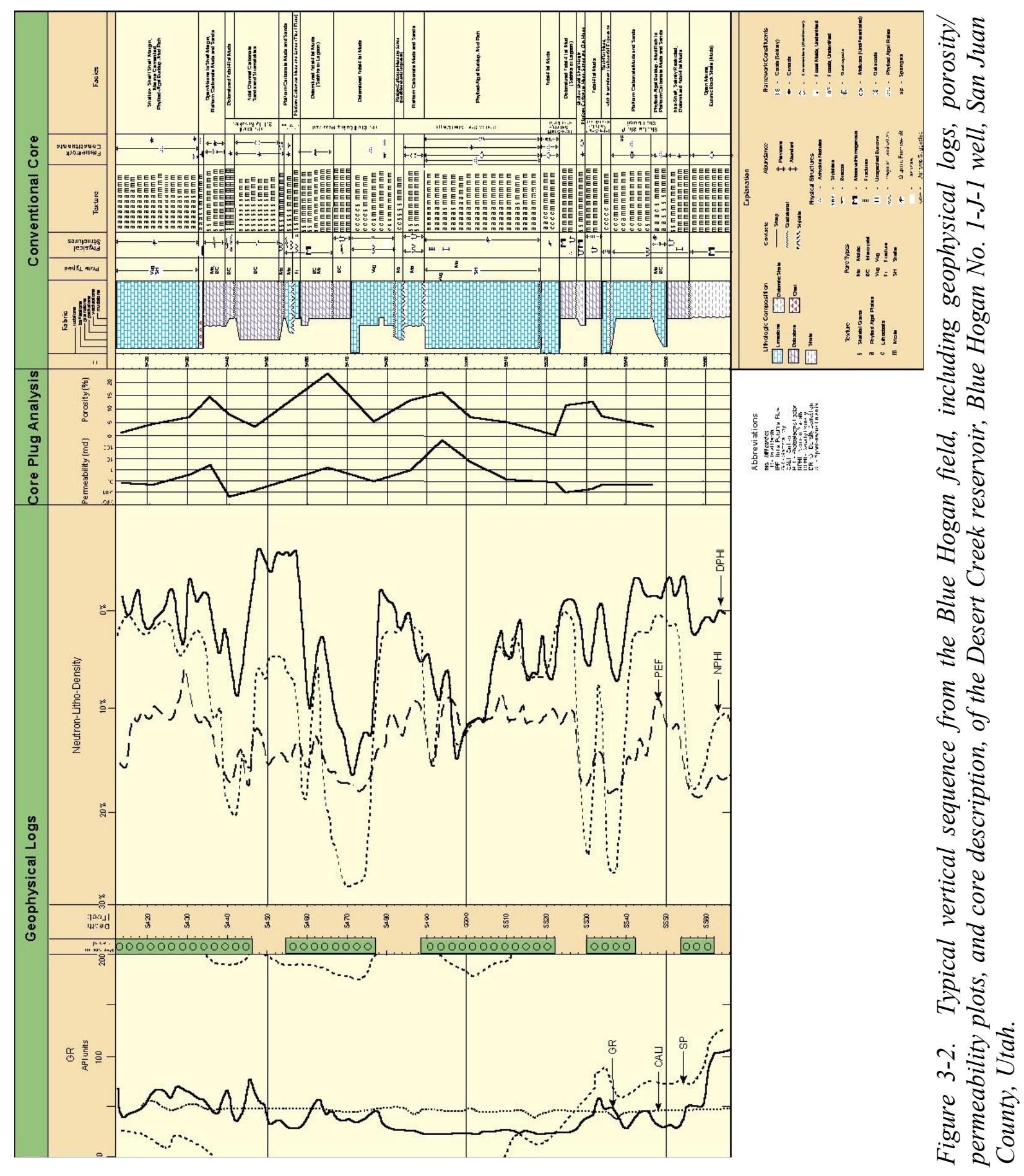




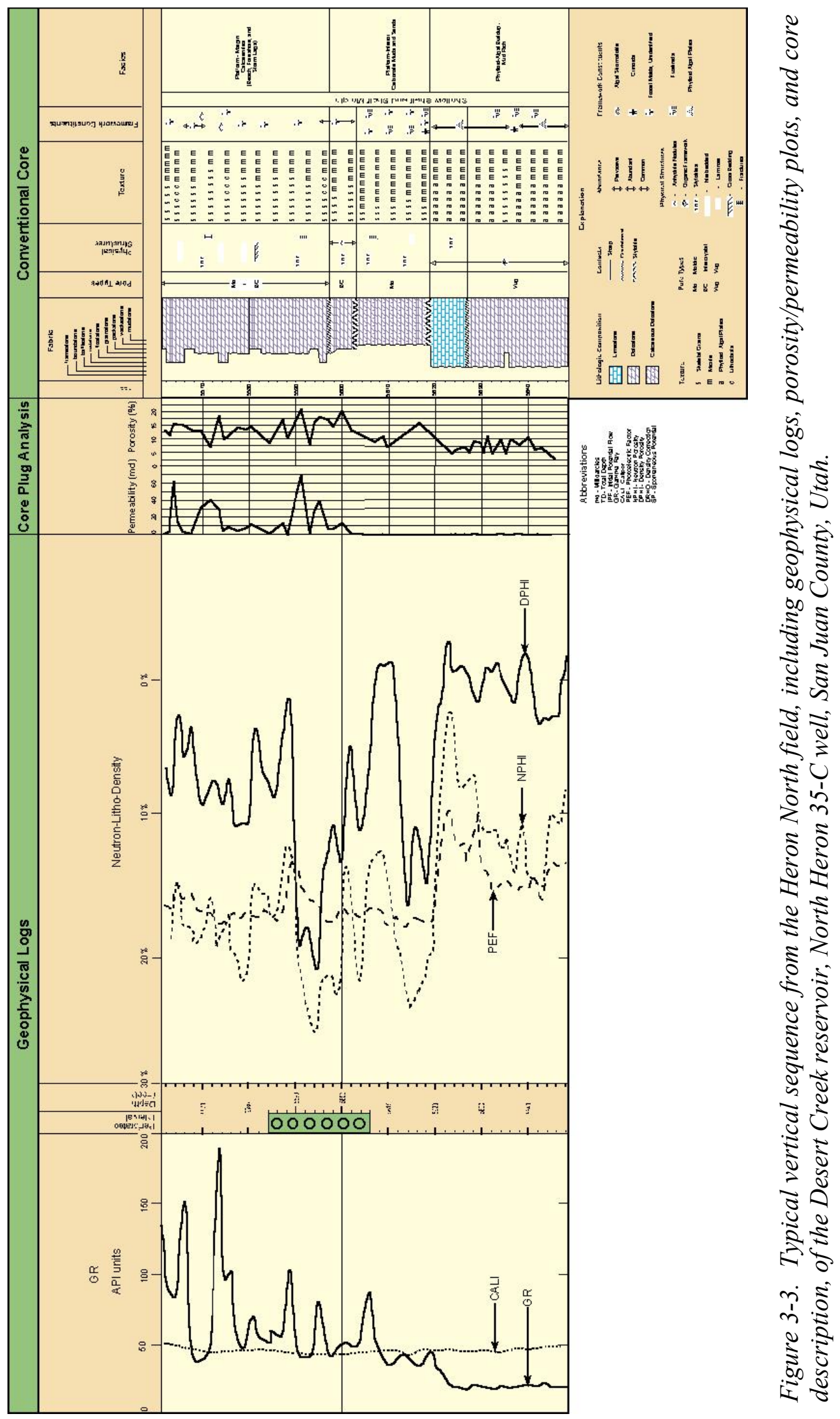




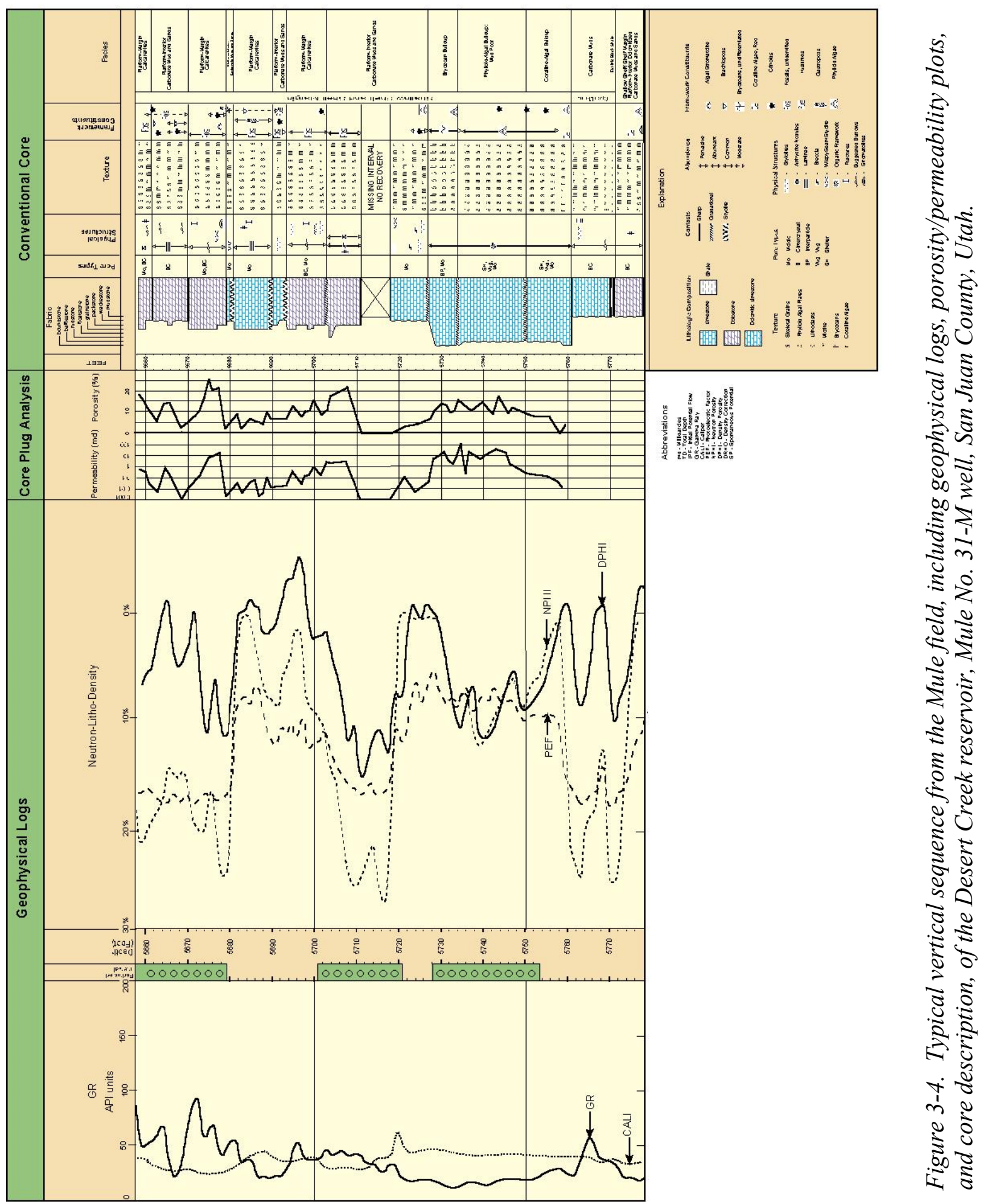




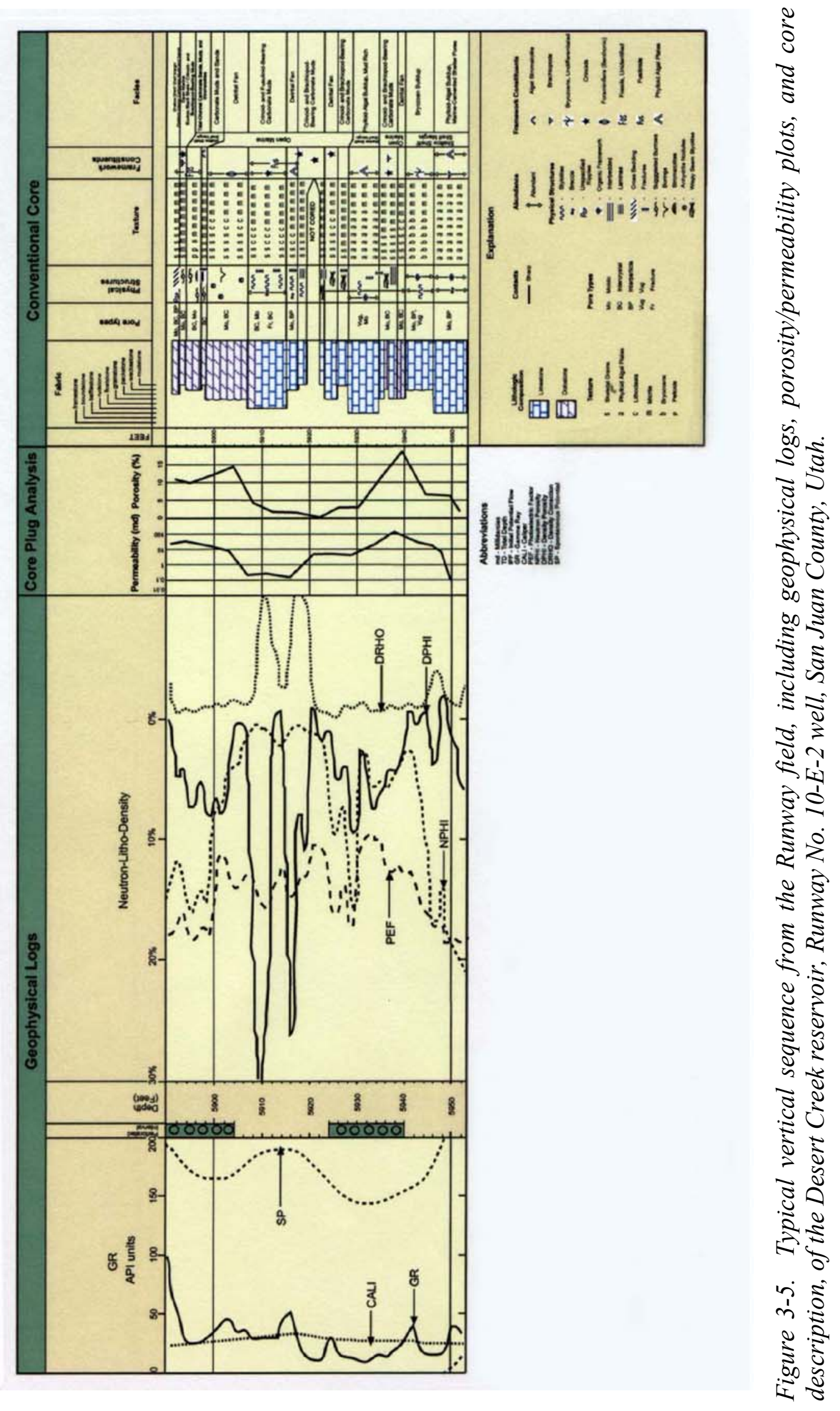




\section{R $24 \mathrm{E}$}

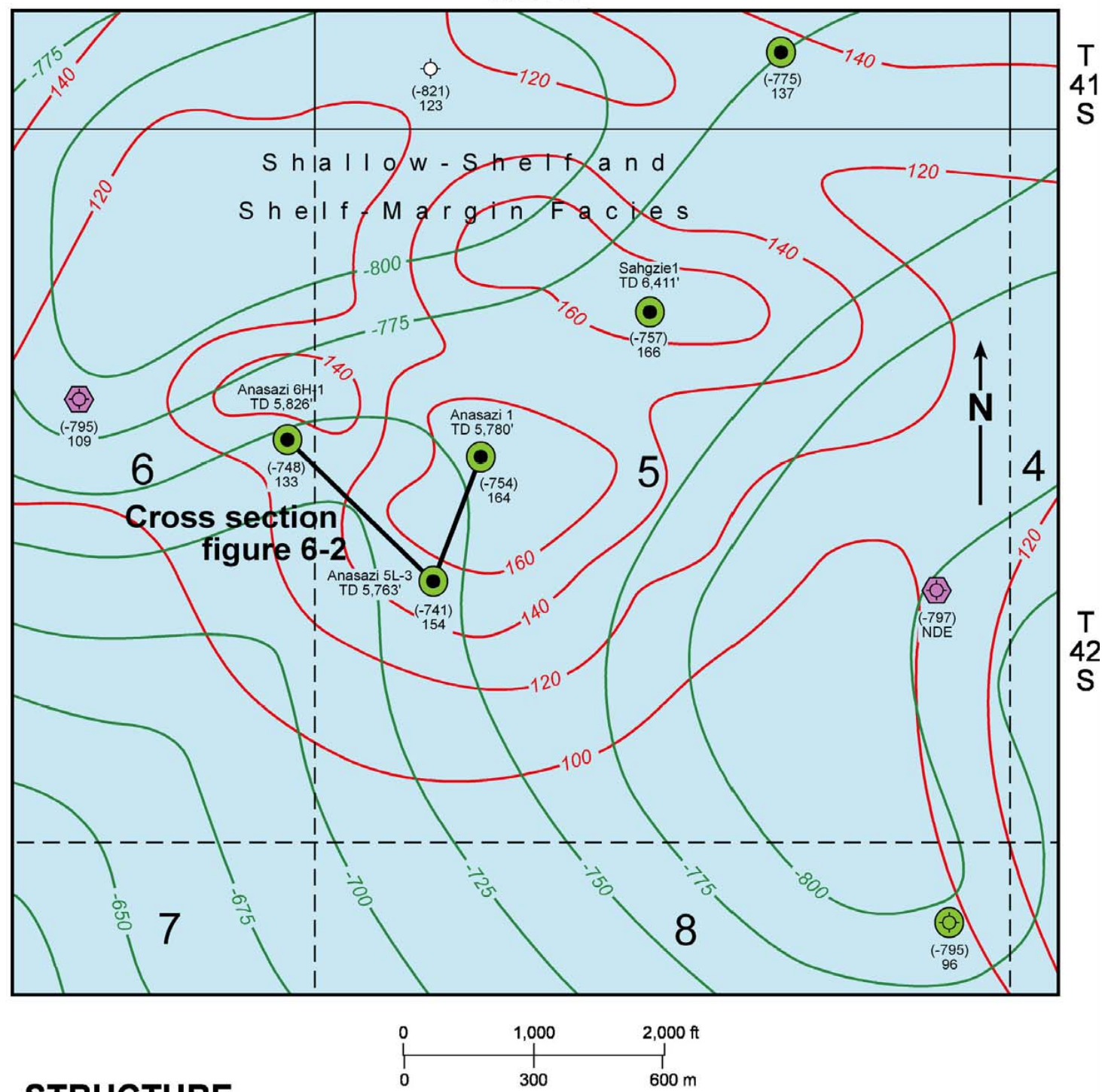

STRUCTURE CONTOUR

Top of Desert Creek

GROSS INTERVAL ISOPACH

Desert Creek

C.I. $=20 \mathrm{ft}($ red line)

EXPLANATION

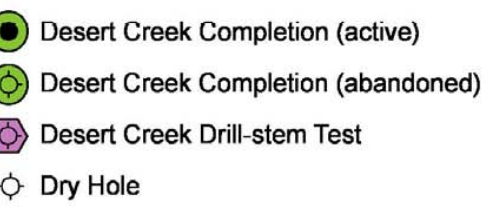

Desert Creek Completion (active)

(ㄱ) Desert Creek Completion (abandoned)

- Dry Hole

\footnotetext{
(-754) Structural Datum (ft)

164 Gross Interval Thickness (ft)

Anasazi 1
TD 5,780

Field Well Name

Total Depth ( $\mathrm{ft}$ )

NDE Not Deep Enough
}

Figure 3-6. Combined Desert Creek zone structure contour and gross interval isopach map, Anasazi field, San Juan County, Utah, Navajo Nation (from Chidsey, Eby, and others, 1996a). 


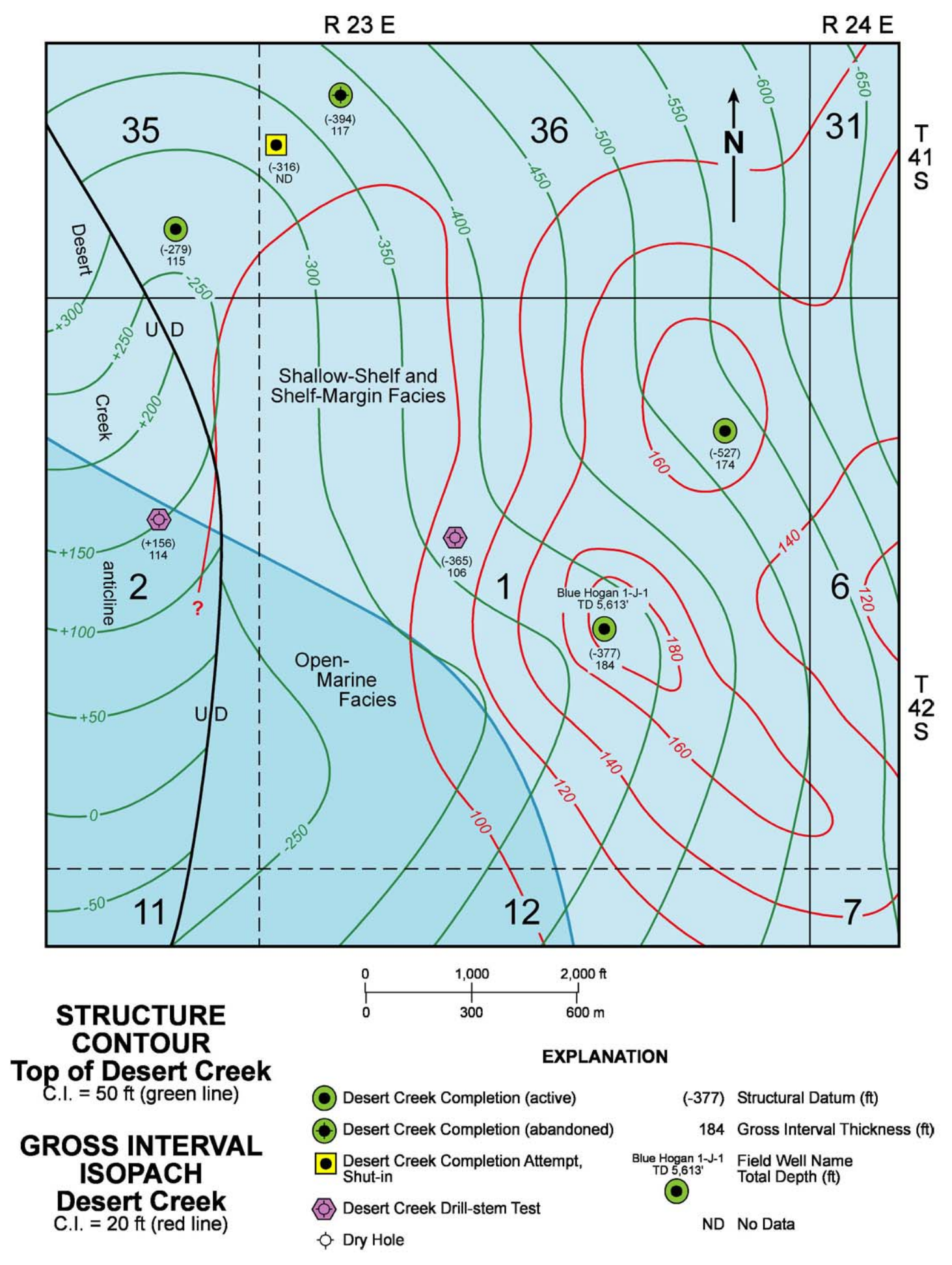

Figure 3-7. Combined Desert Creek zone structure contour and gross interval isopach map, Blue Hogan field, San Juan County, Utah, Navajo Nation (from Chidsey, Eby, and others, 1996b). Hachured lines separate carbonate depositional facies. 


\section{R $25 \mathrm{E}$}

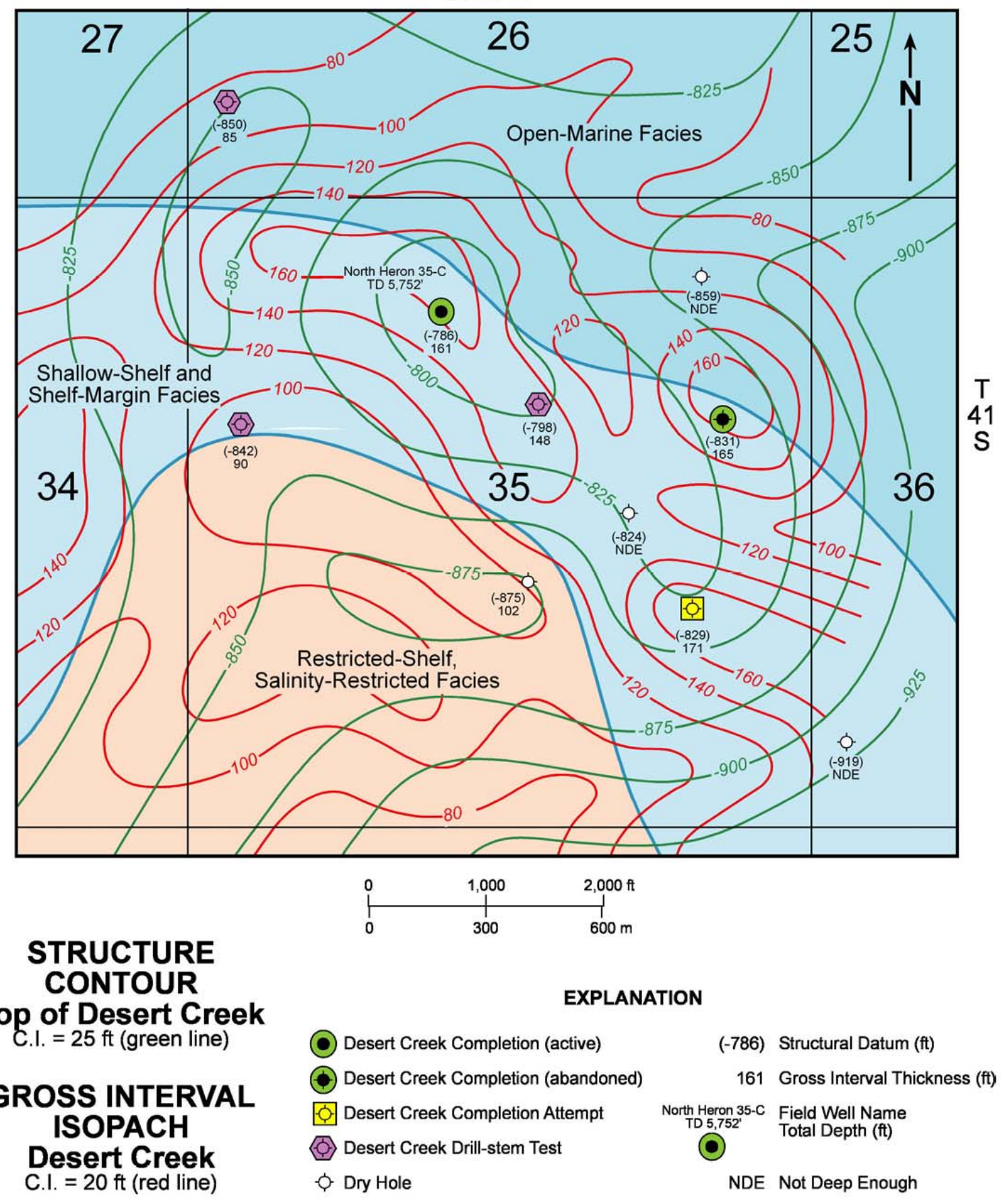

Figure 3-8. Combined Desert Creek zone structure contour and gross interval isopach map, Heron North field, San Juan County, Utah, Navajo Nation (from Chidsey, Eby, and others, 1996c). Hachured lines separate carbonate depositional facies. 


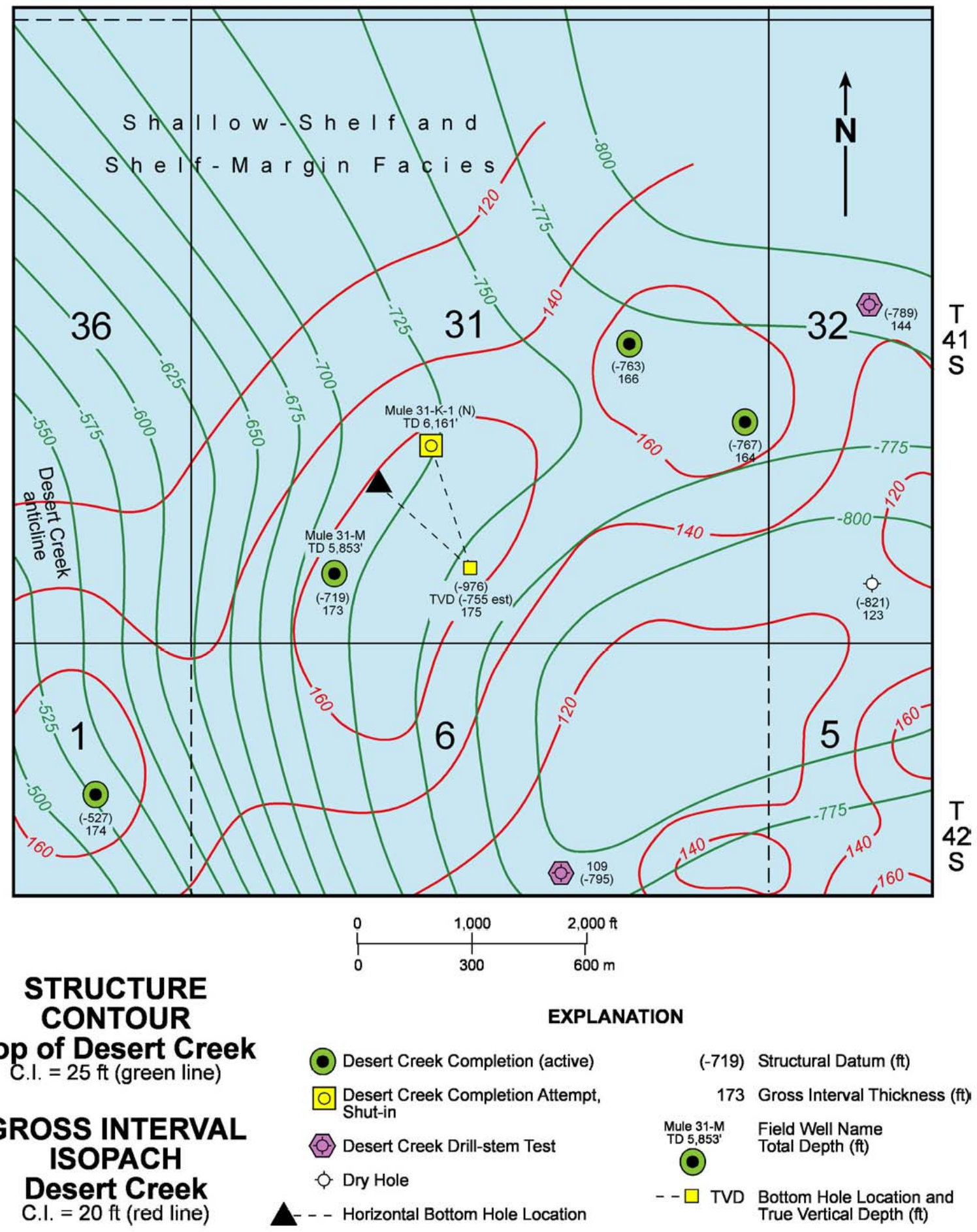

Figure 3-9. Combined Desert Creek zone structure contour and gross interval isopach map, Mule field, San Juan County, Utah, Navajo Nation (from Chidsey, Eby, and others, 1996d). 
R $25 \mathrm{E}$

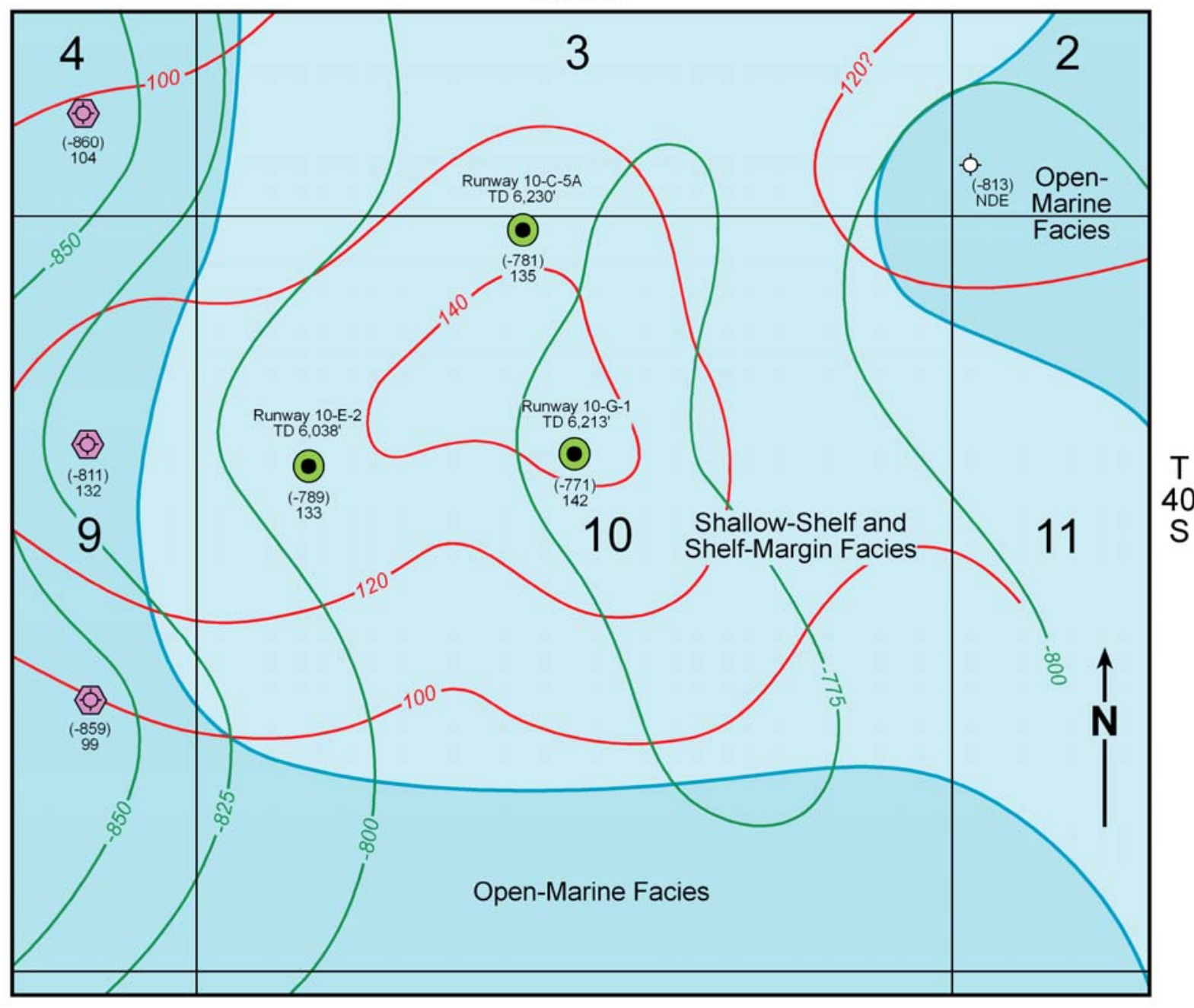

GROSS INTERVAL ISOPACH Desert Creek C.I. $=20 \mathrm{ft}($ red line)

\section{STRUCTURE} CONTOUR

\section{Top of Desert Creek}

C.I. $=25 \mathrm{ft}$ (green line)

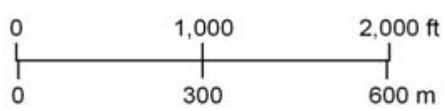

\section{EXPLANATION}

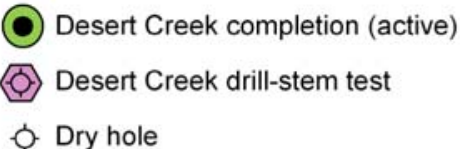

NDE Not deep enough

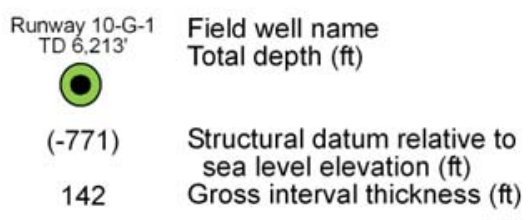

Figure 3-10. Combined Desert Creek zone structure contour and gross interval isopach map, Runway field, San Juan County, Utah, Navajo Nation (from Chidsey, Eby, and others, 1996e). Hachured lines separate carbonate depositional facies. 


\section{General Overviews of Project Fields}

Geologic, reservoir, and production data for each project field are summarized in Chidsey, Eby, and others (1996a-e). Oil and gas are produced from the Pennsylvanian (Desmoinesian) Desert Creek and Ismay zones of the Paradox Formation. The fields were discovered in 1990 and 1991 as part of an ambitious exploration program conducted within the Navajo Nation by Chuska Energy Company (now Harken Southwest Corporation and recently sold to The Rim Energy Companies) and several Australian companies. Seismic surveys and subsurface geology were used to identify prospects. Each carbonate mound is expressed on seismic coverage (figure 3-11) by isochron thickening of the Desert Creek zone, isochron thinning of the overlying Ismay zone, amplitude dimming of the Desert Creek reflector, and a "doublet" development of the Desert Creek event (Johnson and Groen, 1993).

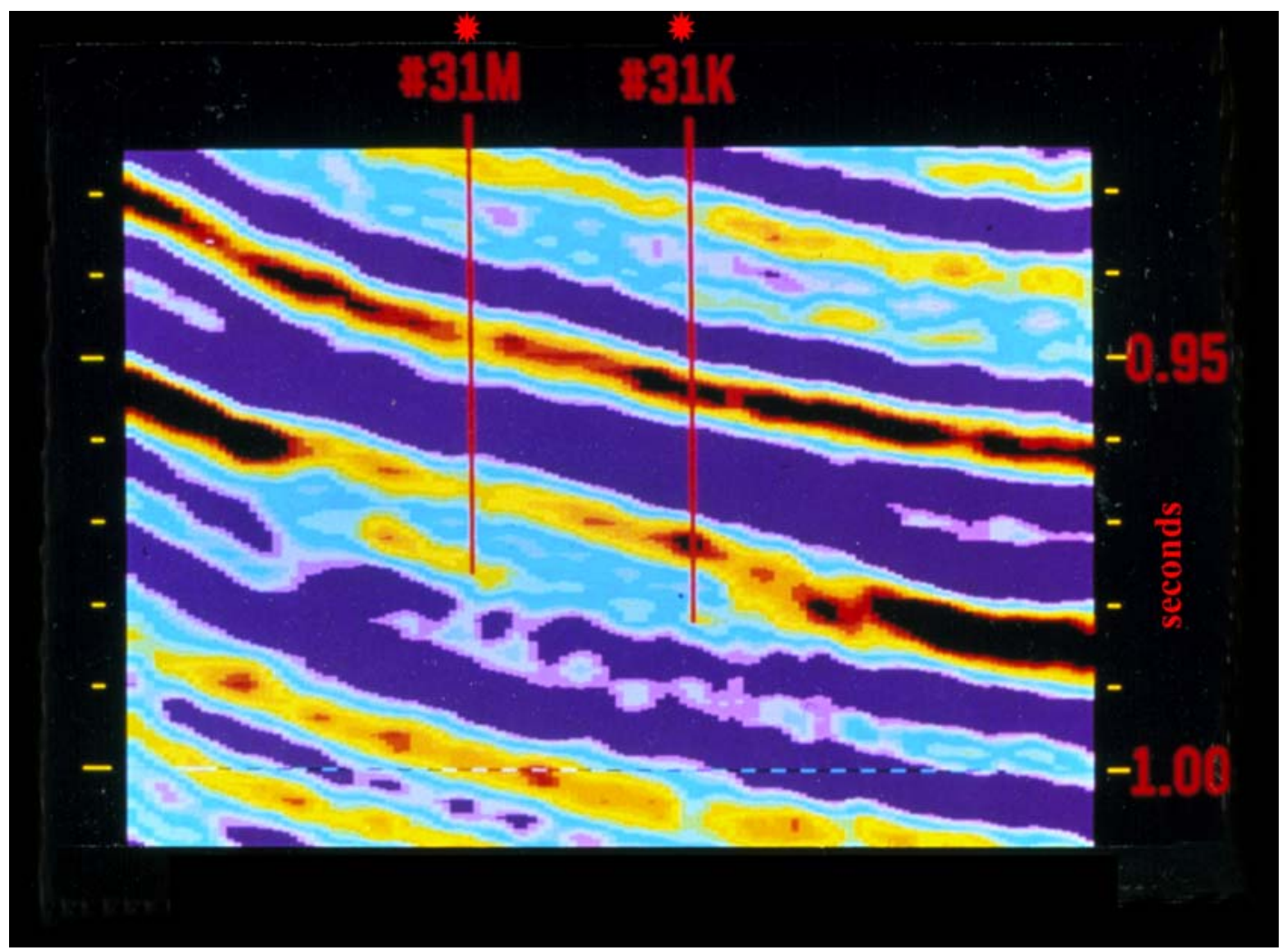

Figure 3-11. Representative seismic line, shaded according to amplitude variations, across Mule field. In general, the lighter the shades the more porous the reservoir rock within the carbonate buildup. The reservoir rock in the noncommercial Mule No. 31-K-1 (N) well is tight while the reservoir rock in the Mule No. 31-M well is more porous, resulting in excellent production. Both wells are located in section 31, T. 41 S., R. 24 E., Salt Lake Base Line, Navajo Nation, San Juan County, Utah. 
Each field consists of one to four wells. Development wells are drilled on either 40-acre (16-ha) spacing or under the 80-acre- (32-ha-) spacing rules established at Greater Aneth field. Completion practices consist of selective perforation and treatment with varying amounts of acid. The reservoir drive is gas expansion. Primary production ranges from 700,000 to $2,000,000$ bbls of oil (BO [111,300-318,000 $\left.\mathrm{m}^{3}\right]$ ) per field at a 15 to 20 percent recovery rate. Geological and engineering data for each field are summarized on table 3-2.

Table 3-2. Geological and engineering data for project fields in the Paradox Basin, San Juan County, Utah.

\begin{tabular}{|l|c|c|c|c|c|c|c|c|}
\hline \multicolumn{1}{|c|}{ Field } & $\begin{array}{c}\text { Depth* } \\
(\mathbf{f t})\end{array}$ & $\begin{array}{c}\text { Area } \\
(\mathbf{a c})\end{array}$ & $\begin{array}{c}\text { Pay } \\
(\mathbf{f t})\end{array}$ & $\begin{array}{c}\text { Porosity } \\
(\mathbf{\%})\end{array}$ & $\begin{array}{c}\text { Permeability } \\
(\mathbf{m d})\end{array}$ & $\begin{array}{c}\text { Water } \\
\text { Saturation } \\
(\mathbf{\%})\end{array}$ & $\begin{array}{c}\text { Reservoir } \\
\text { Temperature } \\
\left({ }^{\circ} \mathbf{F}\right)\end{array}$ & $\begin{array}{c}\text { Initial } \\
\text { Reservoir } \\
\text { Pressure (psi) }\end{array}$ \\
\hline Runway & 5,896 & 193 & 72 & 11.8 & 10.0 & 25.2 & 126 & 2,162 \\
\hline Heron North & 5,584 & 110 & 60 & 15.0 & 17.7 & 32.2 & 126 & 1,934 \\
\hline Anasazi & 5,574 & 165 & 57 & 14.1 & 135.3 & 28.1 & 138 & 1,945 \\
\hline Mule & 5,655 & 48 & 47 & 13.0 & 20.1 & 31.0 & 128 & 2,050 \\
\hline Blue Hogan & 5,400 & 89 & 82 & 9.1 & 33.6 & 29.0 & 128 & 1,800 \\
\hline
\end{tabular}

*Average depth to the top of the reservoir.

\section{Anasazi Field}

Anasazi field (figure 1-1) consists of four wells. The discovery well, the Anasazi No. 1, was completed in 1990 at an initial potential flow (IPF) of 1,705 bbls of oil per day (BOPD $\left[271 \mathrm{~m}^{3} / \mathrm{d}\right]$ ) and 833 thousand cubic feet of gas per day (MCFGPD [23,591 $\left.\mathrm{m}^{3} / \mathrm{d}\right]$ ) from the Desert Creek zone. The Anasazi prospect, near the southwest edge of Greater Aneth field, was identified as a seismic anomaly along the east flank of the Desert Creek anticline. A modified seismic interpretation was completed for the field and converted into a gross Desert Creek isopach map to evaluate the area for additional drilling.

Anasazi field is a lenticular, west- to northeast-trending lobate mound, 4,750 feet $(1,450$ $\mathrm{m})$ long and 2,000 to 3,000 feet (610-914 m) wide (figure 3-6). The reservoir consists of a phylloid-algal mound. The principal reservoir rock in the field is porous algal bafflestone, some grainstone, and dolomitized zones interbedded with low permeable wackestone and mudstone (figure 3-1). Extensive fresh water dissolution and early dolomitization has resulted in good to excellent porosity development and permeability modification.

Cumulative production from Anasazi field is 2,042, $794 \mathrm{BO}\left(324,804 \mathrm{~m}^{3}\right)$ and 1.8 billion cubic feet of gas (BCFG [0.05 billion $\left.\mathrm{m}^{3}\right]$ ) as of January 1, 2002 (Utah Division of Oil, Gas and Mining, 2002). Estimated primary recovery is 2,069,392 $\mathrm{BO}\left(329,033 \mathrm{~m}^{3}\right)$ and 1.89 BCFG $\left(0.05\right.$ billion $\left.\mathrm{m}^{3}\right)$.

\section{Blue Hogan Field}

Blue Hogan field (figure 1-1) consists of one well, the Blue Hogan No. 1-J-1, completed in 1991 at an IPF of 1,167 BOPD $\left(186 \mathrm{~m}^{3} / \mathrm{d}\right)$ and 722 MCFGPD $\left(20,447 \mathrm{~m}^{3} / \mathrm{d}\right)$ from the Desert Creek zone. The Blue Hogan prospect, near the southwest edge of the Greater Aneth field, was identified as a seismic anomaly along the east flank of the Desert Creek anticline. 
Blue Hogan field is a lenticular, northwest to southeast-trending, linear mound, 2,640 feet $(800 \mathrm{~m})$ long and 1,000 feet $(305 \mathrm{~m})$ wide (figure $3-7)$. The reservoir consists of a cementrich, phylloid-algal mound. The principal reservoir rocks in the field are porous, algal bafflestone and dolomitized zones interbedded with low permeability wackestone and mudstone (figure 3-2).

Cumulative production from Blue Hogan field is 341,468 $\mathrm{BO}\left(54,293 \mathrm{~m}^{3}\right)$ and 0.34 BCFG (0.01 billion $\mathrm{m}^{3}$ ) as of January 1, 2002 (Utah Division of Oil, Gas and Mining, 2002). Estimated primary recovery is $645,000 \mathrm{BO}\left(102,555 \mathrm{~m}^{3}\right)$ and $0.968 \mathrm{BCFG}\left(0.03\right.$ billion $\left.\mathrm{m}^{3}\right)$.

\section{Heron North Field}

Heron North field (figure 1-1), southeast of the Greater Aneth field, consists of one well, the North Heron No. 35-C, completed in 1991 at an IPF of 605 BOPD $\left(96 \mathrm{~m}^{3} / \mathrm{d}\right)$ and 230 MCFGPD $\left(6,500 \mathrm{~m}^{3} / \mathrm{d}\right)$ from the Desert Creek zone. The Heron North prospect was identified as a seismic anomaly.

The Heron North field is a lenticular, northwest to southeast-trending, linear mound/ beach complex, 4,220 feet $(1,300 \mathrm{~m})$ long and 2,620 feet $(800 \mathrm{~m})$ wide (figure $3-8)$. The reservoir consists of a bioclastic, calcarenite mound above an anhydrite- and salt-plugged phylloid-algal mound. This calcarenite mound type, which is also productive in the Heron 35$\mathrm{H}$ well 0.5 miles $(0.8 \mathrm{~km})$ southeast of Heron North, developed in a carbonate beach to foreshore environment with moderately high wave energy. Trough cross-bedding is often present. The reservoir consists of alternating 2- to 4-foot- (0.6-1.2-m-) thick packages of uniform beach calcarenite and poorly sorted foreshore and storm lag rudstone or breccia deposits. An 8-foot- (2.4-m-) thick anhydrite lies immediately above the reservoir interval and creates an effective seal. The principal reservoir rocks in the field are porous, sucrosic, dolomitized grainstone and packstone (calcarenite) above tight bafflestone composed of algal stromatolithic mats. The calcarenite and bafflestone intervals are separated by low permeability, dolomitized wackestone and mudstone (figure 3-3). Stylolitization, secondary cementation, and evaporite plugging are minor in the upper portion of the reservoir, but increase with depth. Pores are often lined with bitumen that in many instances plugs pore throats.

Cumulative production from Heron North field is 206,446 BO $\left(32,825 \mathrm{~m}^{3}\right)$ and 0.33 BCFG (0.009 billion $\mathrm{m}^{3}$ ) as of January 1, 2002; the field is currently shutin (Utah Division of Oil, Gas and Mining, 2002). Estimated primary recovery is $990,000 \mathrm{BO}\left(157,410 \mathrm{~m}^{3}\right)$ and 2.65 BCFG (0.08 billion $\left.\mathrm{m}^{3}\right)$.

\section{Mule Field}

Mule field (figure 1-1) consists of two wells, the Mule No. 31-K-1 (N) discovery well and the Mule No. 31-M well, completed in 1991 and 1992 respectively. The Mule No. 31-K-1 (N) well tested approximately $10 \mathrm{BO}\left(1.6 \mathrm{~m}^{3}\right)$ per hour (based on several swab tests) with water cut increasing on each test and produced only $283 \mathrm{BO}\left(45 \mathrm{~m}^{3}\right)$ before being shut-in. The Mule No. 31-M offset well had an IPF of 735 BOPD $\left(117 \mathrm{~m}^{3} / \mathrm{d}\right)$ and 97 MCFGPD $\left(3,000 \mathrm{~m}^{3} / \mathrm{d}\right)$ from the Desert Creek zone. The Mule prospect, near the southwestern edge of the Greater Aneth field, was identified as a seismic anomaly (figure 3-11). 
The Mule field is a lenticular, northeast to easttrending, linear mound/mound flank deposit, 2,640 feet (800 $\mathrm{m})$ long and 900 feet $(274 \mathrm{~m})$ wide (figure 3-9). The reservoir consists of a phylloid-algal mound combined with mound flank detrital deposits. This mound type, which dominates the area southwest of Greater Aneth field, developed where shallow water depth and low wave energy allowed establishment of phylloid-algal colonies on paleohighs. Several beds in the Mule $31-\mathrm{K}-1$ (N) core exhibit characteristics of mound flank deposits such as downslope gravity transport and sharp erosional basal contacts. The top of the phylloid-algal interval is highly irregular with several cross-cutting zones of dissolution cavities possibly from karst development during subaerial exposure. The principal reservoir rocks in the field are porous algal bafflestone (figure 3-12), crinoidal packstone, and dolomitized zones interbedded with low permeability wackestone, mudstone, and dolomite (figure 3-4). Incomplete dolomitization and secondary anhydrite replacement have resulted in poor reservoir properties in some intervals.

Cumulative production from Mule field is $465,003 \mathrm{BO}$ $\left(73,936 \mathrm{~m}^{3}\right)$ and 0.33 BCFG $\left(0.01\right.$ billion $\left.\mathrm{m}^{3}\right)$ as of January 1 , 2002 (Utah Division of Oil, Gas, and Mining, 2002). The original estimated primary recovery was $430,603 \mathrm{BO}(68,466$ $\left.\mathrm{m}^{3}\right)$, which has now been surpased, and 0.288 BCFG $(0.008$ billion $\mathrm{m}^{3}$ ).

\section{Runway Field}

Runway field (figure 1-1) consists of three wells, with the discovery well, the Runway No. 10-G1, completed in 1990 at an IPF of 825 $\operatorname{BOPD}\left(131 \mathrm{~m}^{3} / \mathrm{d}\right)$ and 895 MCFGPD $\left(25,000 \mathrm{~m}^{3} / \mathrm{d}\right)$ from commingled Desert Creek and upper Ismay zones. The Runway prospect was identified as a high-resolution, common-depth point seismic anomaly in the northern Aneth platform area. This anomaly, east of the Greater Aneth field (figure $3-13$ ), is located on the upthrown edge of a basement-involved, Mississippian-age normal fault that was a topographic high during

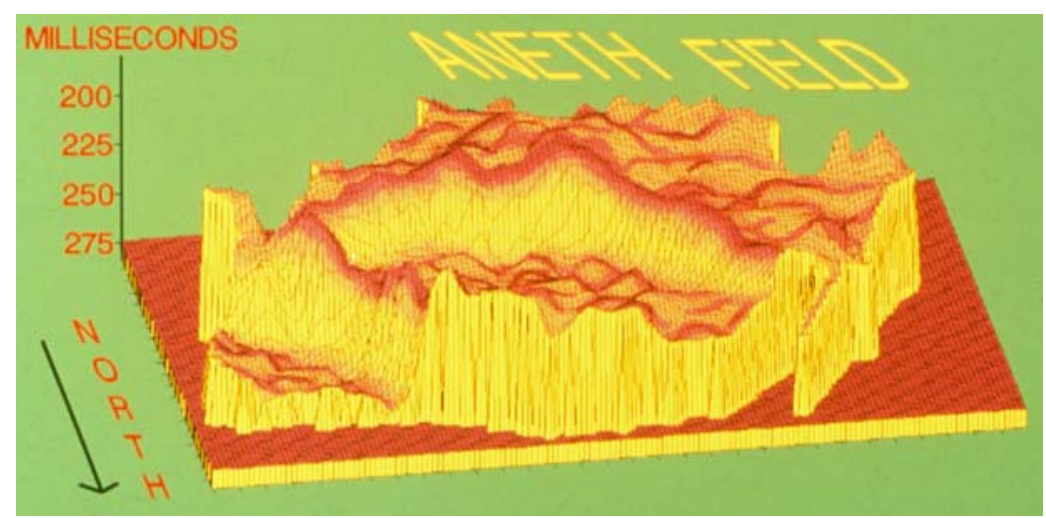

Figure 3-13. Three-dimensional "net" view to the southwest of the surface on top of the Mississippian Leadville Limestone and the north-bounding faults that control the localization of small algal and other carbonate buildups such as at the Runway field. This computerized presentation was produced from a closely spaced seismic grid. Paradox Formation time. 
The Runway field is a lenticular, west to east-northeast-trending, lobate mound, 4,750 feet $(1,450 \mathrm{~m})$ long and 2,640 feet $(800 \mathrm{~m})$ wide (figure $3-10)$. The reservoir consists of a bryozoan-dominated mound with phylloid-algal mound intervals. The presence of two mound types at Runway field suggests that the water depth changed as the carbonate deposits built up over the fault-controlled paleohigh. The principal Desert Creek reservoir rocks in the field are bindstone and framestone, rarely dolomitized, in the bryozoan-dominated interval and porous bafflestone (calcified plates of the green algae Ivanovia) with some grainstone and occasional dolomitization in the phylloid-algal mound interval (figure 3-5). The Ismay reservoir rock is sucrosic dolomite. Both carbonate buildups are interbedded with low permeability wackestone and mudstone.

The Runway field lies along a generally gas-rich trend to the east and north of Greater Aneth field. Cumulative production from Runway field is $832,382 \mathrm{BO}\left(132,349 \mathrm{~m}^{3}\right)$ and 2.86 BCFG (0.08 billion $\mathrm{m}^{3}$ ) as of January 1, 2002 (Utah Division of Oil, Gas and Mining, 2002). Oringinal estimated primary recovery was $800,000 \mathrm{BO}\left(127,200 \mathrm{~m}^{3}\right)$, which has also been surpased, and 2.99 BCFG (0.09 billion $\left.\mathrm{m}^{3}\right)$.

\section{Reservoir Facies}

Three, generalized, regional facies belts, each with unique types of facies, are identified in the Desert Creek zone of the Paradox Formation (figures 2-1 and 2-2): (1) open-marine, (2) shallow-shelf and shelf-margin, and (3) intra-shelf, salinity-restricted facies belts (Chidsey, Eby, and Lorenz, 1996; Chidsey, 1997). All five project fields, as well as the other Desert Creek fields in the region, are located within the shallow-shelf and shelf-margin facies belt. This facies belt includes shallow-shelf carbonate buildups, platform-margin calcarenites, and platform-interior carbonate muds and sands.

\section{Carbonate Buildups}

Productive carbonate buildups are located in the shallow-shelf and shelf-margin areas. These buildups can be divided into three types: (1) phylloid algal, (2) coralline algal, and (3) bryozoan (Eby and others, 1993; Chidsey, Eby, and Lorenz, 1996). The controls on the development of each buildup type were water depth, prevailing wave energy, and paleostructural position. Mapping of seismic anomalies and reservoir thicknesses indicates that carbonate phylloid-algal buildups, or mounds, were doughnut or horseshoe shaped, or a composite of the two shapes (figure 3-14). Many of the phylloid-algal buildups were large enough to enclose interior lagoons.

Phylloid-algal buildup facies: Phylloid-algal buildup facies can be subdivided into shelter, mud-rich, and solution breccia facies. The shelter, phylloid-algal buildup facies represents a moderate energy environment with well-circulated water. Water depths ranged from 1 to 40 feet $(0.3-12 \mathrm{~m})$. The depositional fabric is bafflestone. Rocks representing this facies contain in-situ phylloid-algal plates (Ivanovia and Eugonophyllum), encrusting forams (for example Tetrataxis), soft peloidal mud, and minor amounts of internal sediment (mud or grains deposited after storms [suspended load]). These rocks have a high faunal diversity. 


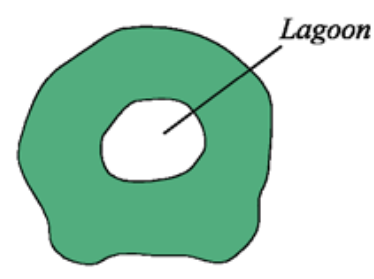

Doughnut

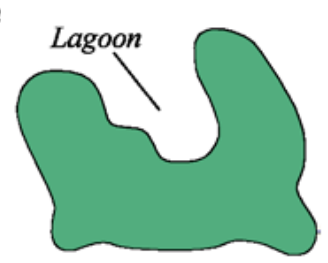

Horseshoe
$S H A L L O W-S H E L F \quad S E A$

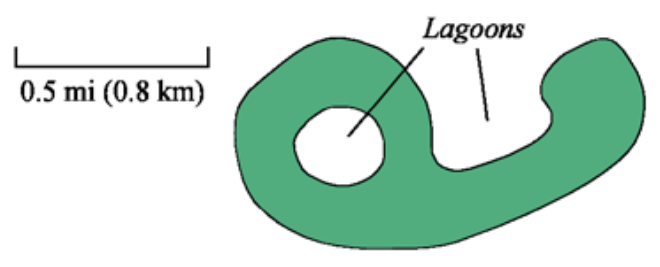

Figure 3-14. Map view of typical carbonate buildup shapes (most often phylloid algal in composition) on the shallow carbonate shelf during Desert Creek time.

\section{Composite}

The mud-rich, phylloid-algal buildup facies represents a moderate- to low-energy environment where the buildup was in a protected position with poorly circulated water. Water depths ranged from 3 to 40 feet $(1-12 \mathrm{~m})$. The depositional fabrics include bafflestone, wackestone, and mudstone. Rocks of this facies contain in-situ phylloid-algal plates surrounded by lime mud, fine skeletal debris, and microfossils.

The solution breccia, phylloid-algal buildup facies represent a moderate- to low-energy environment modified by meteoric solution and collapse (karst to microkarst settings). Water level ranged from 3 feet $(1 \mathrm{~m})$ above sea level to 30 feet $(9 \mathrm{~m})$ below sea level. The depositional fabrics of this facies include disturbed rudstone and floatstone with some packstone. Rocks of this facies contain chaotic phylloid-algal and exotic clasts, peloids, and internal sediments (muds).

The best stratigraphic hydrocarbon traps in the region are associated with phylloid-algal buildup facies. These traps are widely distributed, are small to moderate in size, and can be readily identified on seismic records. Shelter, phylloid-algal buildup facies are observed in Anasazi, Mule, and Runway fields (figure 1-1). Mud-rich, phylloid-algal buildup facies are also present in Anasazi, Runway, and Jack fields. The solution breccia, phylloid-algal buildup facies are observed in Mule, Runway, and Monument fields. Variable amounts of early marine cement are found in mud-rich (Monument field) and shelter (Blue Hogan and Brown Hogan fields), phylloid-algal buildup facies. Bafflestones within these facies have excellent reservoir properties where primary shelter porosity is well developed. However, anhydrite and early marine, botryoidal to fibrous cements occasionally plug pores.

The principal buildup process for phylloid-algal growth occurred during high stands of sea level (figure 3-15A) (Chidsey, Eby, and Lorenz, 1996). Phylloid-algal mounds generally developed on the platform-interior carbonate muds and sands. The mound substrate of platform-interior carbonates is referred to as the platform interval. Calcified phylloid-algal plates sheltered abundant primary "vugs," with mounds of phylloid algae building upward within the available accommodation space. As mounds grew, detrital skeletal material was 


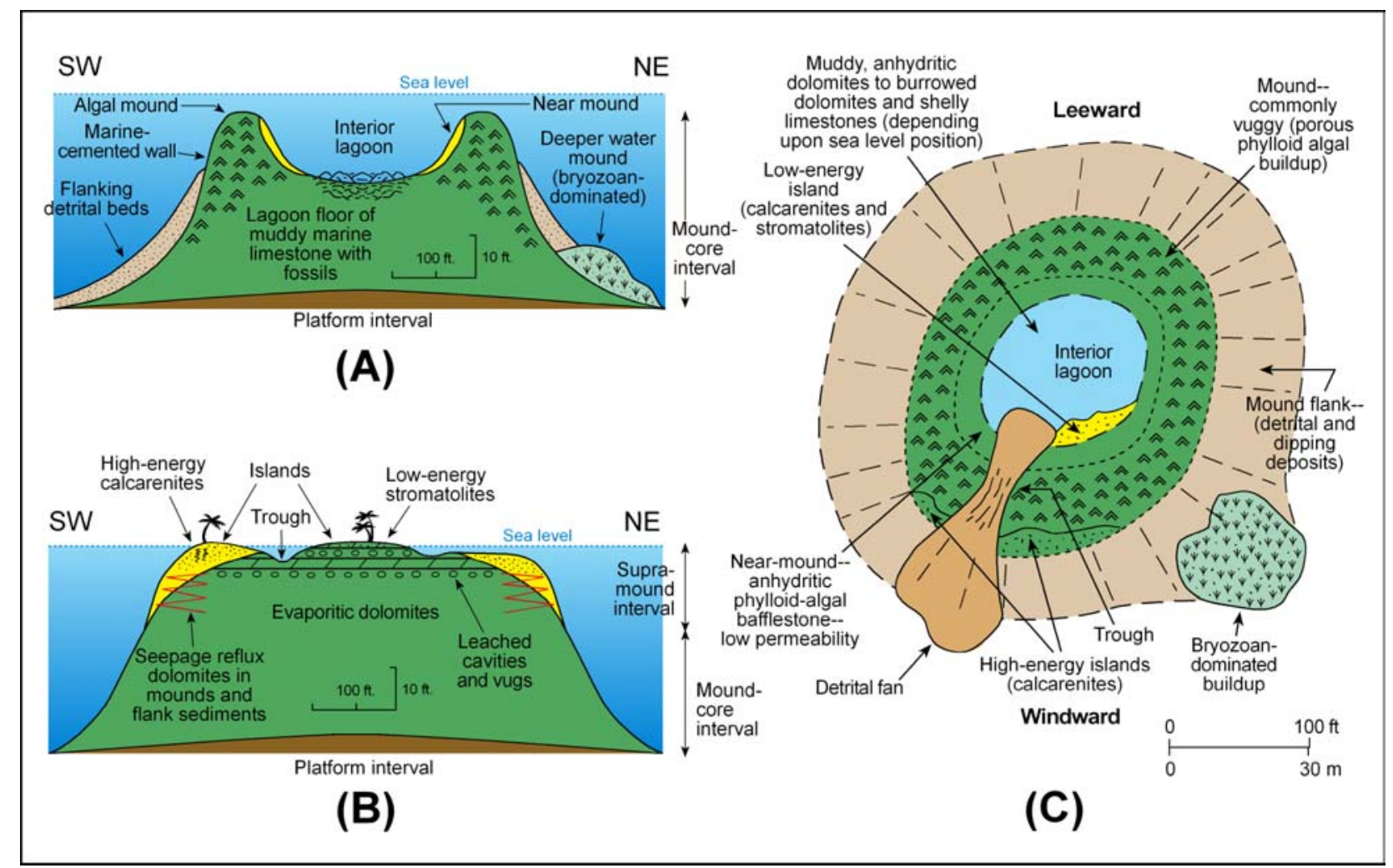

Figure 3-15. Detailed environmental setting of Desert Creek algal buildup features surrounding the Greater Aneth field. (A) Cross section during high stands of sea level when the mound was actively growing. (B) Cross section during low stands of sea level when the mound experienced porosity modification, erosion of the mound margins, evaporite dolomites filled in the lagoon, and troughs (tidal channels) and islands developed on the top. (C) Map view of idealized algal buildup (from Chidsey, Eby, and Lorenz, 1996).

shed and deposited as dipping beds along the exterior flanks and within interior lagoons. The floors of the interior lagoons consisted of muddy, marine limestone with fossils. Early marine cementation commonly occurred along mound walls facing open-marine environments. Bryozoan-dominated buildups developed in deeper water along the flanks of the phylloid-algal mounds. Coralline-algal buildups developed in association with marine-cemented walls and detrital-fan complexes. These skeletal bafflestone and cementstone portions of the buildups are referred to as mound-core intervals and are easily identified in core.

During low stands of sea level, these buildups experienced considerable porosity modification (figure 3-15B). Leached cavities, vugs, and seepage-reflux dolomites developed in the mound core and flank sediments. Evaporitic dolomites and anhydrite filled the interior lagoons. Islands consisting of high-depositional- energy calcarenites and low-depositionalenergy stromatolites, as well as troughs representing tidal channels, formed on the tops of buildups during times of subaerial exposure (figure $3-15 \mathrm{~B}$ and $\mathrm{C}$ ). These portions of the buildups are referred to as supra-mound intervals. 
Coralline-algal buildup facies: Coralline-algal buildup facies are located along the shallowshelf margins facing open-marine waters or within the intra-shelf, salinity-restricted facies belt (where they are non-productive). On the shallow shelf, this facies represents a low- to highenergy environment with well-circulated water. Water depths ranged from 25 to 45 feet (8-14 $\mathrm{m}$ ). These buildups are a component of the wall complex (figure 2-2) in association with early marine cementation and are stacked vertically. They may surround other types of buildup complexes.

The depositional fabrics of coralline-algal buildup facies are selectively dolomitized bindstone, boundstone, and framestone. Rocks representing this facies contain calcareous, encrusting and bulbous coralline (red) algae, variable amounts of lime mud, microfossils, and calcispheres.

Coralline-algal buildup facies are poor stratigraphic hydrocarbon traps, but contribute minor amounts of oil to the production at Cajon Mesa and Runway fields (figure 1-1). These traps are rare, small, and identification on seismic records is difficult, requiring good well control for delineation. Although these reservoirs may appear good on geophysical logs, porosity and permeability are generally low.

Bryozoan buildup facies: Bryozoan buildup facies are located on the deeper flanks of phylloid-algal buildup complexes (figure 3-15A). This facies represents a low energy environment with well-circulated water. Water depths ranged from 25 to 45 feet $(8-14 \mathrm{~m})$. These facies are prevalent on the northeast part of the shallow shelf where winds from the east, and paleotopography from Mississippian-aged normal faulting, produced better marine conditions for bryozoan colony development.

The depositional fabrics are bindstone, bafflestone, and packestone that are rarely dolomitized. Rocks of this facies contain the following diagnostic constituents: bryozoan colonies (Chaetetes), small rugose corals, occasional small calcareous sponges and phylloidalgal plates, microfossils, and lime muds.

The bryozoan buildup facies are fair to poor stratigraphic hydrocarbon traps. This facies is productive at Cajon Mesa and Runway fields (figure 1-1). These traps are small and their geometry is difficult to determine. Porosity is good but pores (intraskeletal) are isolated unless connected by bryozoan sheets; permeability is variable. Minor to abundant amounts of early marine botryoidal to fibrous cement plugs pores.

\section{Platform-Margin Calcarenites}

The platform-margin calcarenite facies are located along the margins of the larger shallow shelf or the rims of phylloid-algal buildup complexes. This facies represents a highenergy environment where shoals and/or islands developed as a result of regularly agitated, shallow marine processes on the shelf. Characteristic features of this facies include mediumscale cross-bedding and bar-type, carbonate, sand-body morphologies. Stabilized calcarenites occasionally developed subaerial features such as beach rock, hard grounds, and soil zones. Water level ranged from 5 feet $(1.5 \mathrm{~m})$ above sea level to 20 feet $(6 \mathrm{~m})$ below sea level.

The depositional fabrics of the calcarenite facies include grainstone and packstone. Rocks representing this facies typically contain the following diagnostic constituents: coated grains, hard peloids, bioclastic grains, shell lags, and intraclasts. 
Calcarenite facies are moderately good stratigraphic and diagenetic hydrocarbon traps, like those observed in Heron North, Heron, and Anasazi fields for example (figure 1-1). However, these traps are limited in extent, relatively small, and difficult to identify on seismic records. Grainstones within calcarenite facies traps have excellent reservoir properties where primary interparticle and secondary intercrystalline porosity (from dolomitization) are well developed. However, some calcarenites only have moldic pores that result in classic "heart break" reservoirs. In addition, bitumen (or solid hydrocarbons) sometimes plug intercrystalline and interparticle pores.

\section{Platform-Interior Carbonate Muds and Sands}

The platform-interior carbonate mud and sand facies are wide spread across the shallow shelf. This facies represents a low to moderate energy environment. Mud and sand were deposited in subtidal (burrowed), inter-buildup, and stabilized grain-flat (pellet shoals) settings intermixed with tubular and bedded tempestites. Water depths ranged from 5 feet to 45 feet (1.5-14 m).

The depositional fabrics of the platform-interior carbonate mud and sand facies include grainstone, packstone, wackestone, and mudstone. Rocks representing this facies typically contain the following diagnostic constituents: soft-pellet muds, hard peloids, grain aggregates, crinoids and associated skeletal debris, and fusulinids.

The platform-interior carbonate mud and sand facies can contain reservoir-quality rocks if dolomitized. This facies is present in Anasazi, Heron, Heron North, and Runway fields (figure 1-1).

\section{Trapping Mechanism and Reservoir Heterogeneity}

Hydrocarbons are stratigraphically trapped in porous and permeable lithotypes within the mound-core and supra-mound intervals of the Desert Creek carbonate buildups. These intervals are effectively sealed by impermeable platform intervals at the base, marine muds on the flanks, and a 20-foot- (6-m-) thick layer of anhydrite, usually at the top of the Desert Creek zone. Primary oil recovery is about 40 percent in mound-core intervals, but 15 percent or less in the supra-mound intervals (Chidsey, Eby, and Lorenz, 1996). In these traps, determining the nature, location, and extent of reservoir heterogeneity is the key to increasing oil recovery.

Three factors create reservoir heterogeneity within productive mound-core and supramound intervals: (1) variations in lithotypes, (2) mound relief and flooding surfaces, and (3) diagenesis. The extent of these factors, and how they are combined, affect the degree to which they create barriers to fluid flow.

\section{Lithotypes}

Ten distinct lithotypes, each of which exhibits a characteristic set of reservoir properties, have been identified from conventional core in the mound-core and supra-mound intervals (Chidsey, Eby, and Lorenz, 1996; Chidsey, 1997). They include: tight mudstones, packstones, wackestones, and marine-cemented grainstones (also present on the buildup flanks of both intervals); similar carbonate fabrics (mudstones, packstones, wackestones, and grainstones) exhibiting enhanced porosity resulting from dolomitization and/or leaching found in the supra- 
mound interval (and also scattered throughout the buildup flank areas); and thick, porous, highly permeable phylloid-algal lime bafflestones; and associated mound-flank breccias (slumped and chaotic mixed carbonates) which are almost entirely restricted to the mound-core interval. Geometries and patterns of spatial arrangement of these lithotypes can be inferred from outcrop analogue studies, and by comparison with previous work in the nearby Greater Aneth field (Brinton, 1986; Best and others, 1995; Weber, Sarg, and Wright, 1995; Weber, Wright, and others, 1995; Beall and others, 1996; Gianniny and Simo, 1996; and Grammer and others, 1996).

The mound-core intervals are the most homogenous part of these buildups and are dominated by bafflestones and a few thin dolomudstones, packstones, and wackestones. The overlying supra-mound intervals exhibit the greatest heterogeneity with multiple combinations of lithotypes and various lithofacies thicknesses. Overall, the supra-mound intervals have lower permeability, but surprisingly higher average porosity, than the underlying mound-core intervals.

\section{Mound Relief and Flooding Surfaces}

The nature of the original surfaces of supra-mound intervals can add to the reservoir heterogeneity of these buildups. For example, multiple troughs formed by tidal currents may contain good quality grainstones. However, these grainstones are typically separated by poor quality lithotypes that were deposited adjacent to the troughs. In addition, these deposits may not be connected to one another in other parts of the buildup surfaces. Thus, what might appear as the same units in core or on geophysical logs from one well to another, may be time equivalent but separate in terms of fluid flow.

Subaerial exposure of the buildups may have produced karst zones (depending on prior mound relief) favorable to reservoir development. Relative sea-level rise produced flooding surfaces, or time lines, usually recorded as thin shales, which act as barriers or baffles to fluid flow (figure 3-16). As many as eight, correlative, flooding surfaces have been identified in some buildups. Lithotypes between these surfaces are genetically related in time and space, thus correlation of these sequences must not cross time lines (Weber, Wright, and others, 1995).

\section{Diagenesis}

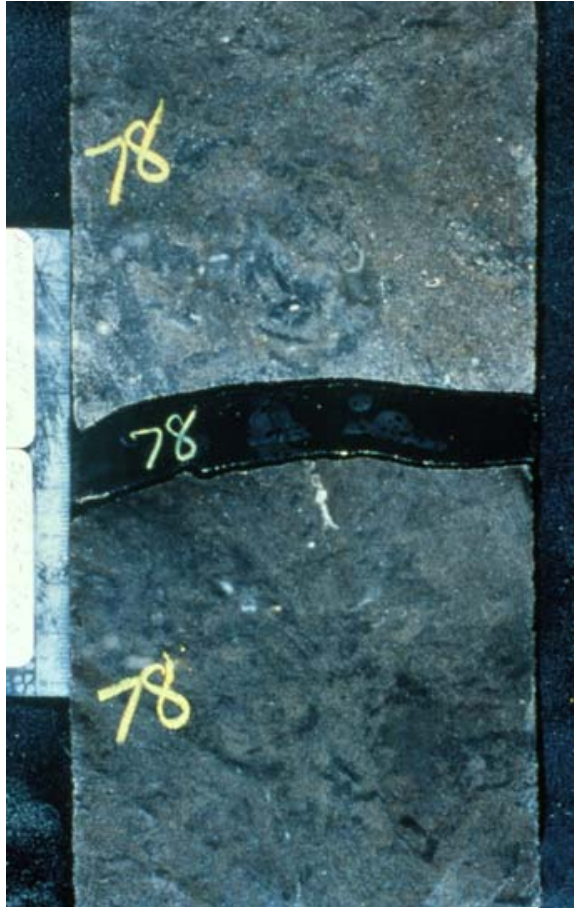

Figure 3-16. Shale break representing a probable flooding surface or 5th-order parasequence at 5,678 feet $(1,730 \mathrm{~m})$ in the Anasazi No. 5L-3 well, Anasazi field, San Juan County, Utah.

The diagenetic fabrics and porosity types found in the various hydrocarbon-bearing rocks of each field can be an indicator of reservoir flow capacity, storage capacity, and potential for water-and/or $\mathrm{CO}_{2}$-flooding. In order to determine the diagenetic histories of the various Desert Creek reservoirs, 50 thin sections of representative samples were selected from the conventional cores of each field for petrographic description, and to evaluate shallow-shelf/ 
shelf-margin phylloid-algal, bryozoan, and calcarenite carbonate buildups. Each core was photographed (figure 3-17) and additional close-up photos were taken of: (1) typical moldic, vuggy, dolomitized, karstbrecciated, stylolitic as well as preserved primary porosity styles, (2) visible cement types, (3) sedimentary structures, and (4) pore plugging anhydrite and halite. Carbonate fabrics were determined according to Dunham's (1962) and Embry and Klovan's (1971) classification schemes. We analyzed the reservoir diagenetic fabrics and porosity types of these buildups to: (1) predict facies patterns, (2) determine the sequence of diagenetic events, and (3) provide data input for the reservoir modeling and simulation studies.

Diagenetic characterization focused on reservoir heterogeneity, quality, and compartmentalization within each of the five project fields. All depositional, diagenetic, and porosity information was placed into the context of the production history of each field in order to construct a detailed overview for each enhanced recovery candidate. Of special interest is the determination of the most effective pore systems for oil drainage versus storage.

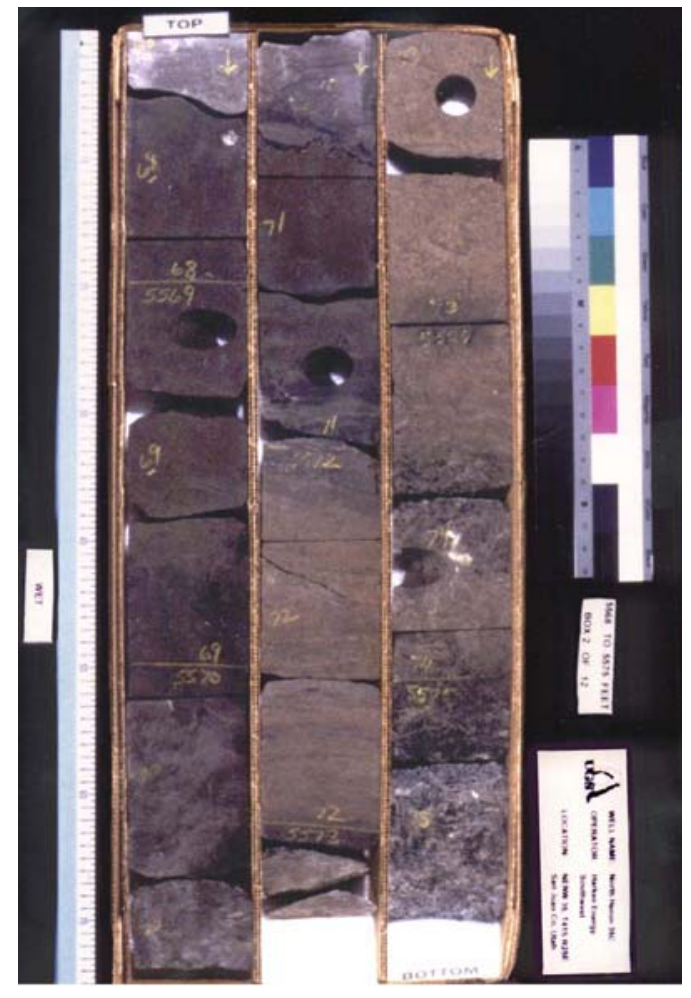

Figure 3-17. Core photograph of the highly dolomitized, oil-saturated calcarenite section of the North Heron No. 35-C well, Heron North field.

Diagenetic environments: Most shallow-shelf/shelf-margin carbonate buildups or mounds had relief with exposure occurring when sea level fell. This setting produced four, major, generally early, diagenetic environments (figures 3-18 and 3-19): (1) fresh-water (meteoric) vadose zone (above the water table, generally at or near sea level), (2) meteoric phreatic zone (below the water table), (3) marine phreatic zone, and (4) mixing zone (Longman, 1980). The "iceberg" principle (the Ghyben-Herzberg theory), which is that for every foot the water table rises above sea level there may be 20 feet $(6.1 \mathrm{~m})$ of fresh water below the water table, a 1:20 ratio, can generally be applied to both carbonate mound and island buildups (Friedman and Sanders, 1978). Neomorphism, leaching/dissolution, and fresh-water cementation (dog-tooth, stubby, and small equant calcite) took place within the vadose and meteoric phreatic zones.

The meteoric and marine phreatic zone were separated by a mixing zone (fresh and sea water), all of which changed with sea level fluctuation. Early dolomitization took place in the mixing zone. Most carbonate buildups (fields) have a mixing zone and as well as a fresh-water overprint.

That portion of the carbonate buildup facing the open-marine environment was generally a steep-wall complex where early-marine cements (such as fibrous isopachous, botryoidal, and radiaxial cements) were deposited from invading sea water flowing through the system. The opposite side of the mound typically bordered a hypersaline lagoon filled with dense brine that seeped into the phreatic zone (seepage reflux) to form a wedge-shaped zone of low-temperature dolomite; both early replacement dolomite and dolomite cement. 


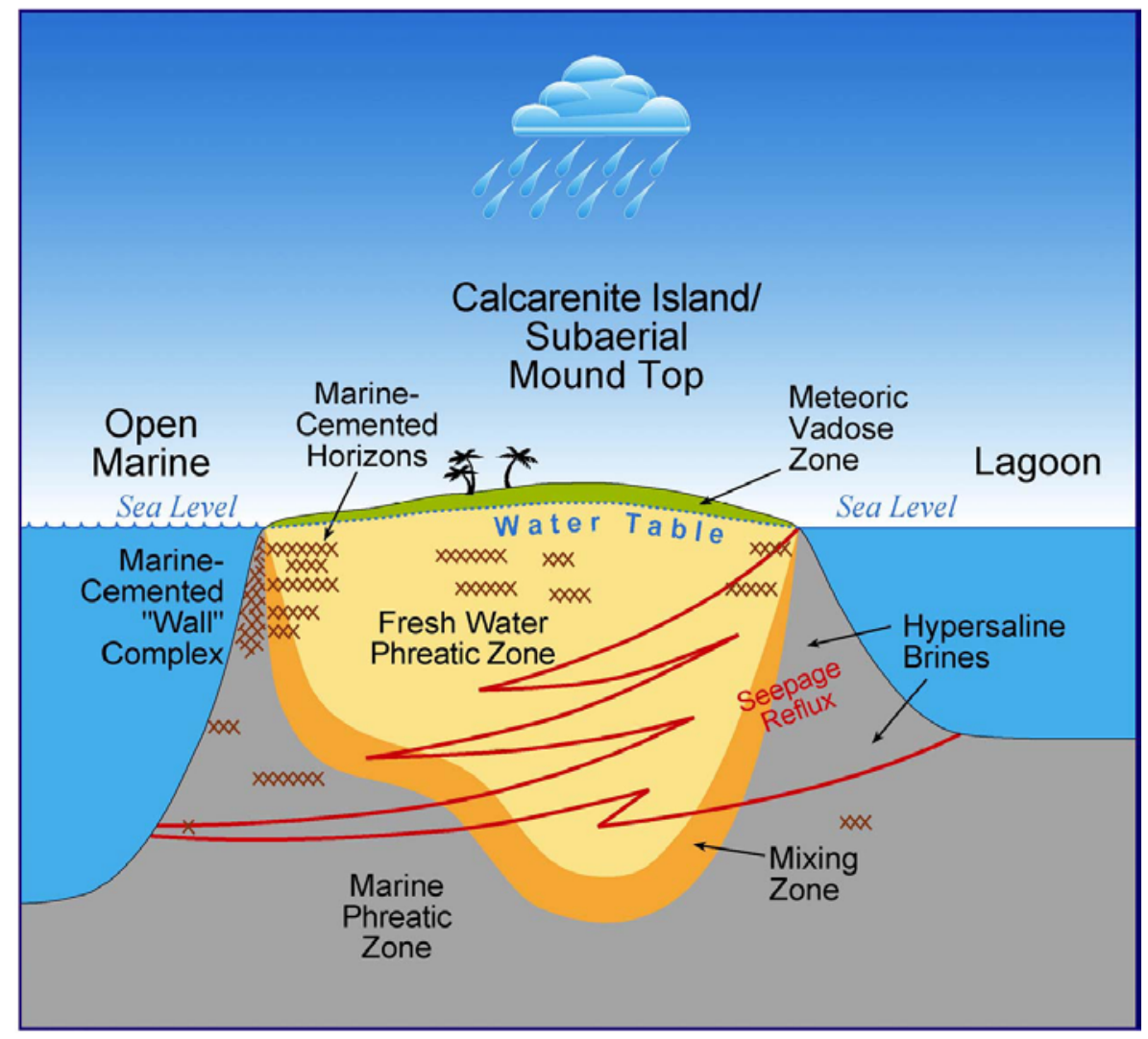

Figure 3-18. Model of early diagenetic environments found in the Desert Creek zone of the Paradox Formation, southern Paradox Basin (modified from Longman, 1980).

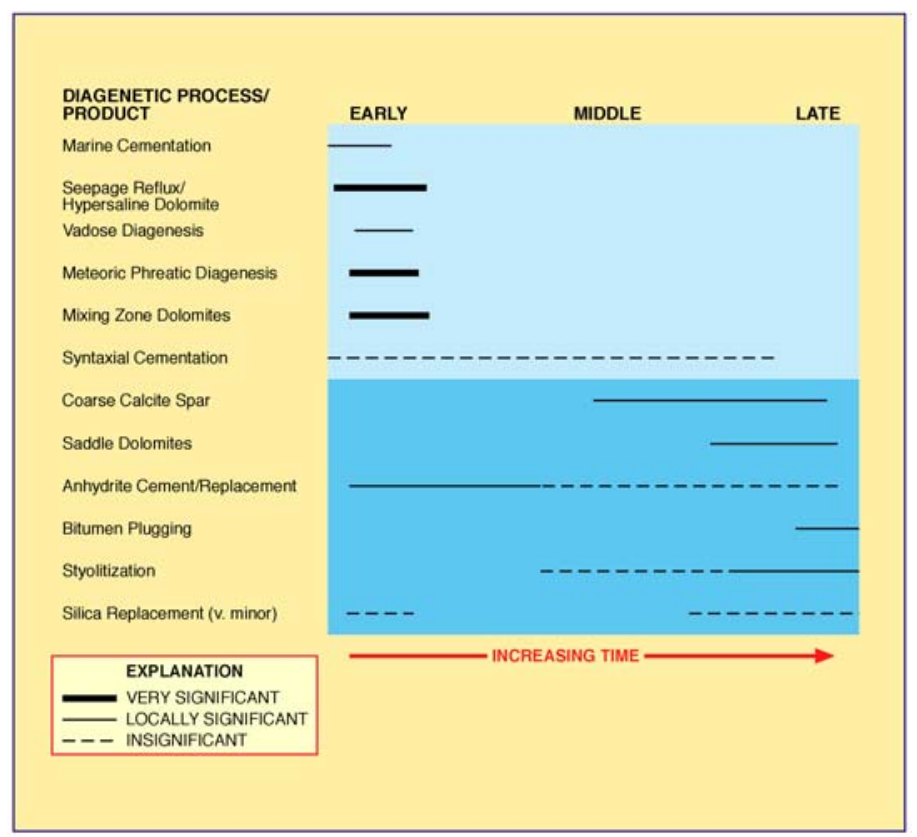

Figure 3-19. Ideal diagenetic sequence through time, including processes and products. 
Post-burial diagenesis included syntaxial cementation, silicification, late calcite spar, saddle dolomite, stylolitization, bitumen plugging, and anhydrite replacement (figure 3-19). There is an observed progression from least to most important (syntaxial cementation to anhydrite replacement) which relates to increased reservoir heterogeneity in the case-study fields. Some of these diagenetic products create barriers and baffles to fluid flow. They are not observed on seismic records, difficult to predict, and locally influence reservoir performance, storage capacity, and drainage. Finally, these post-burial diagenetic processes are not as significant in the project fields as earlier diagenetic modifications.

Characteristics of marine cementation: Early marine cementation occurs in two settings: (1) the "wall" complex on windward side (botryoidal fans and radiaxial blade cements) of the buildup, and (2) scattered horizons across interior of buildups (fibrous isopachous and micritic cements). Slabbed core segments from the Blue Hogan No. 1-J-1 shows the typical pattern of marine cementation within the well-lithified "wall" complex at the higher-energy margin of a small phylloid-algal mound (figure 3-20). Isopachous bands of cements are characteristic of the "wall." Figure 3-21 shows two generations of probable marine cements. The earlier generation was a brown micritic to microfibrous cement (between arrows) which was followed by a bladed radiaxial generation. Filling of most original pore space was by the radiaxial cements.

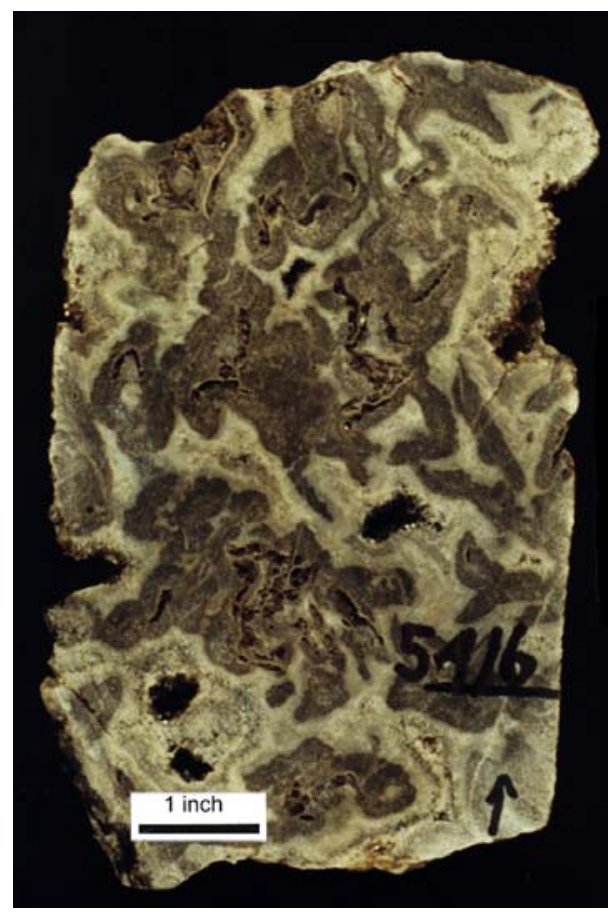

Figure 3-20. Slabbed core segments from 5,415.5 to 5,416.1 feet $(1,650.6-1,650.8 \mathrm{~m})$ of the Blue Hogan No. 1-J-1 well showing the typical pattern of marine cementation within the well-lithified "wall" complex.

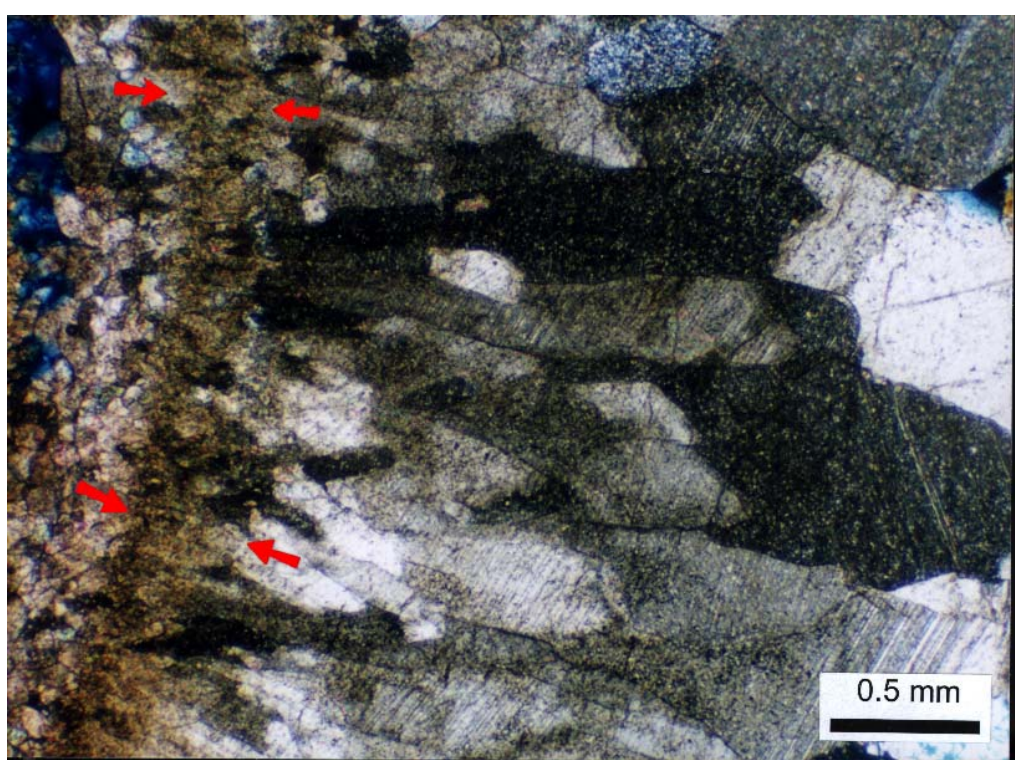

Figure 3-21. Photomicrograph (crossed nicols) of two generations of probable marine cements. Blue Hogan No. 1-J-1 well, 5,420.3 feet (1,652 m), Blue Hogan field. 
Locally, cemented zones can have a major impact on reservoir flow and storage capacity. Pervasive marine cement within a "wall" complex may be indicative of a nearby buildup/mound.

Characteristics of meteoric diagenesis (in limestone facies): Dissolution is the dominant porosity-enhancing process of meteoric diagenesis and creates molds, vugs, and channels (figure 3-22). Much of the original fabric remains or can be determined. Early dissolution of lime muds creates microporosity. Indicative cements include stubby to equant calcite and "dogtooth" calcite spars that sporadically line pores (figure 3-23). Vadose zones generally have less cement than the fresh-water phreatic zones. The depth/thickness of the meteoric vadose and fresh-water phreatic zones is dependent on the extent and duration of subaerial exposure as well as the amount of meteoric water influx.

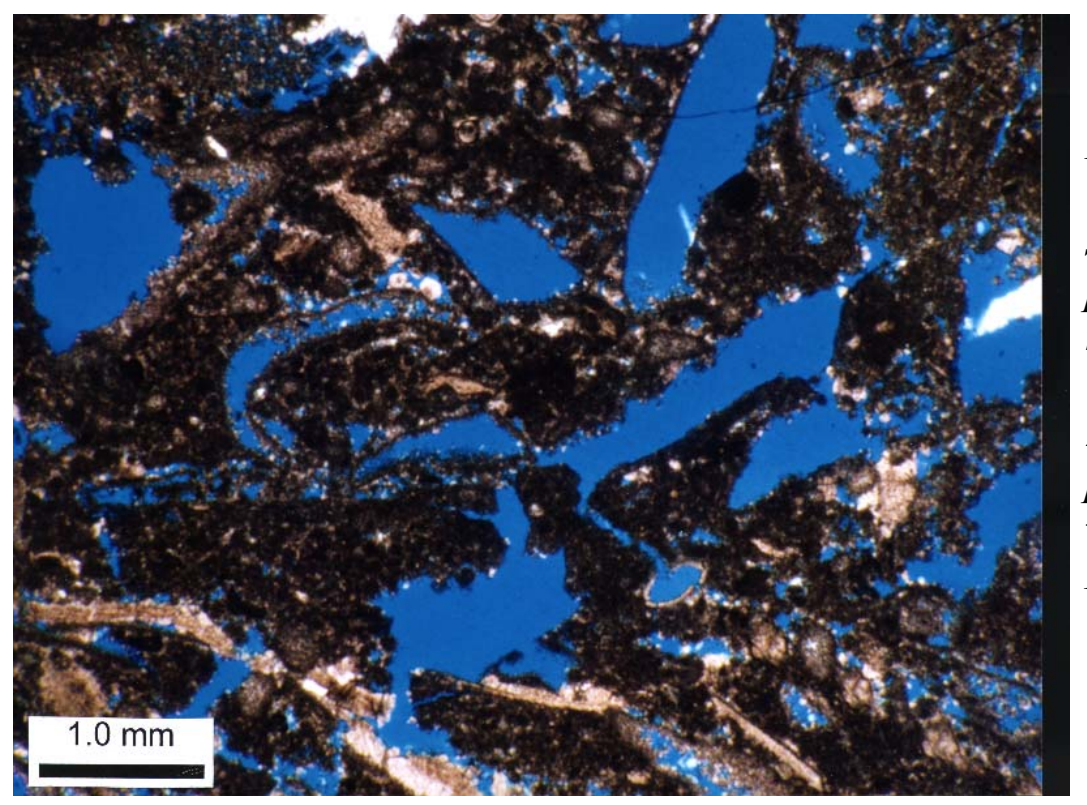

Figure 3-22. Photomicrograph (plane light) of interconnected solution channel and moldic porosity with very little visible meteoric cements; porosity = 13.2 percent, permeablility $=$ 20.4 millidarcies [md] by coreplug analysis). Mule No. 31-M well, 5,729.8 feet $(1,746.4 \mathrm{~m})$, Mule field.

Figure 3-23. Photomicrograph (plane light) of early solution porosity within a phylloid-algal facies partially occluded by stubby to equant to "dogtooth" spar cements of probably meteoric phreatic origin; prosity $=12.5$ percent, permeability 53.8 md by coreplug analysis. These types of cements have degraded the permeability of these solutionenhanced pore systems. Runway No. 10-C-5A well, $6,127.4$ feet $(1,867.5 \mathrm{~m})$, Runway field.

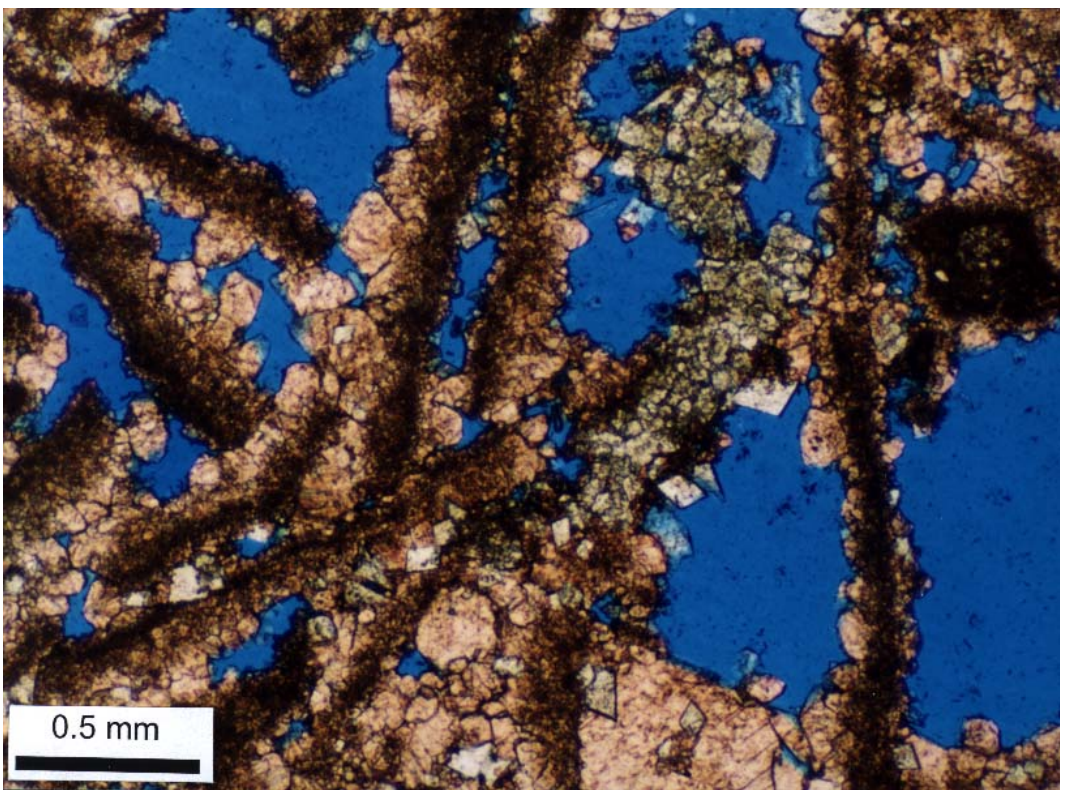


Locally, meteoric diagenesis enhances reservoir performance. Extensively leached intervals may have both excellent storage and flow capacity, and should be considered candidates for $\mathrm{CO}_{2}$ flooding projects. Microporosity increases storage capacity but limits fluid recovery.

\section{Characteristics of dolomitization:}

Dolomization can be divided into two types, mixing zone and seepage reflux, each with different characteristics (figure 3-24). Mixing zone dolomitization is usually incomplete dolomitization (fine-grained crystals). Some of the original fabric, micritization, and/or evidence of fresh-water dissolution often still remains. There are variable percentages of microintercrystalline and intercrystalline porosity. Mixing zone dolomitization is generally thinner than intervals affected by other diagenetic processes. The depth of the mixing zone is dependent on the thickness of the fresh-water phreatic zone, the volume of fresh water available, and/or the amount of subaerial exposure. Locally, mixing zone dolomitization may reduce or enhance reservoir performance.

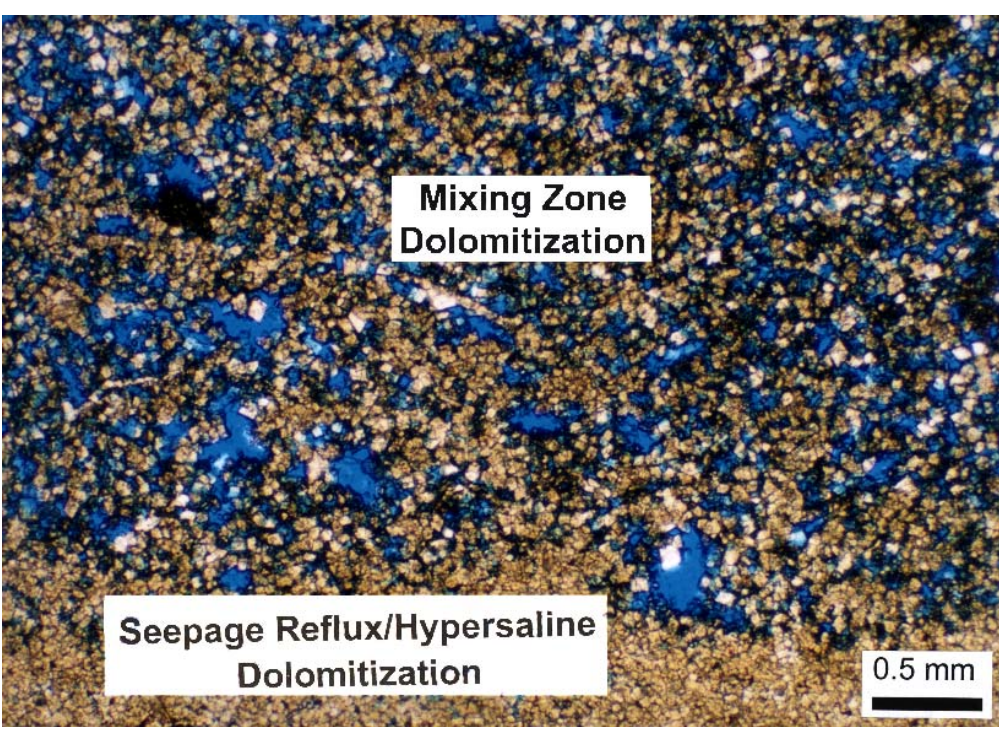

Figure 3-24. Photomicrograh (plane light) of a dolomitized wackestone/packstone showing the contrast between probable seepage reflux/hypersaline dolomitization toward the base and more porous mixing zone dolomitization above; porosity $=20.3$ percent, permeability $=39.8$ md by core-plug analysis. Note with ghosts of probable ostracods and crinoids. Runway No. 10C-5A well, 6,120.2 feet $(1,865.3 \mathrm{~m})$, Runway field.

Affected intervals may have a modest to good storage capacity; flow capacity can be highly variable.

Seepage reflux dolomization is usually complete dolomitization. Little original fabric/ matrix remains. Crystals are fine to medium grained, often sucrosic; intercrystalline porosity dominates (figure 3-25). Seepage reflux dolomization occurs in mounds associated with lagoons where hypersaline brines are concentrated. It overprints the fresh-water phreatic, marine phreatic, and mixing zones across the entire extent of the mound buildup. Thick seepage reflux dolomites are often proximal to evaporite-plugged lagoonal sediments. Locally, seepage reflux dolomitization can enhance both reservoir flow and storage capacity. Those reservoirs with excellent storage capacity may be considered candidates for $\mathrm{CO}_{2}$ flooding projects.

Anasazi field: The producing mud-poor to mud-rich, mound-core interval (at a depth from 5,646 to 5,670 feet $[1,721-1,728 \mathrm{~m}]$ ) in the Anasazi field is a limestone with a packstone to bafflestone fabric (figure 3-1). Framework grains consist of phylloid-algal plates (dominating), brachiopods, bryozoans, pelloids, ostracods, and forams. Early marine cement is present and a limited amount of fresh-water influence is indicated either from the vadose or outside the fresh- 


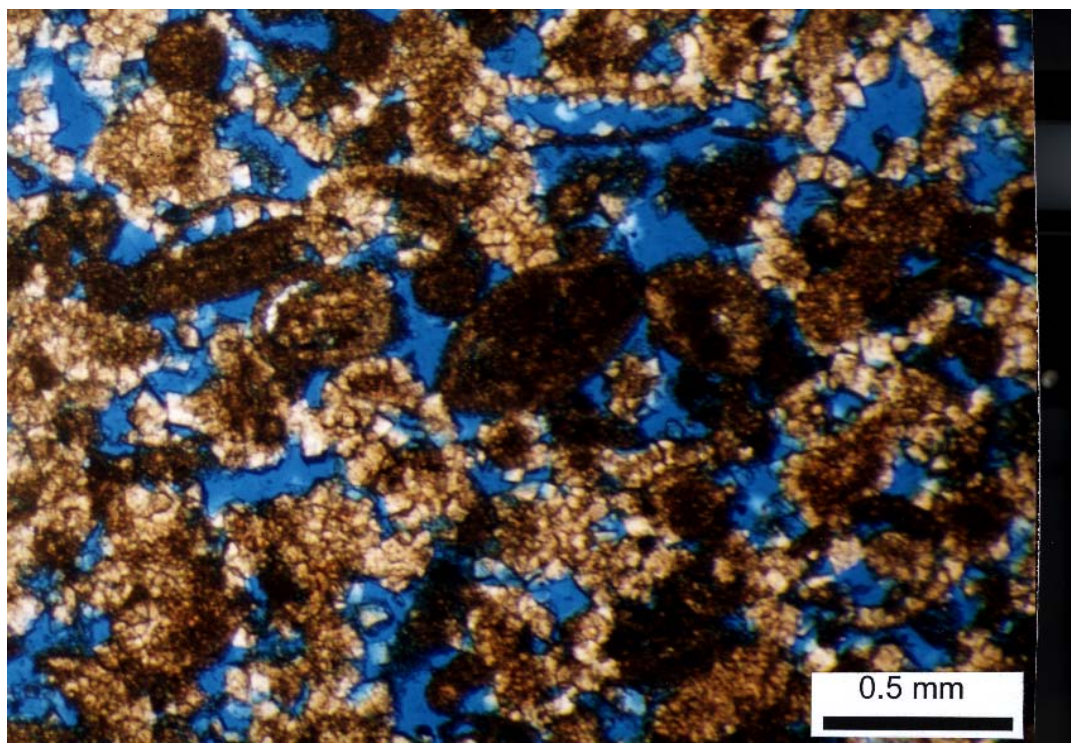

Figure 3-25. Photmicrograph (plane light) of dolomitized, well sorted, pelloidal/oolitic/bioclastic grainstone; porosity $=13.4$ percent, permeability $=33.9$ md by core-plug analysis. Note the very fine crystalline dolomite formed by seepage reflux processes followed by partial dissolution and other meteoric overprints. The combination of both processes has led to good storage potential and excellent flow capacity. North Heron No. 35-C well, 5,569.2 feet $(1,697.4 \mathrm{~m})$, Heron North field.

water (phreatic) zone resulting in some fresh-water cement. There is some bitumen plugging and anhydrite replacement. The diagenetic events occurred in the following order: (1) fibrous isopachous early marine cementation, (2) some stubby to equant to dog-tooth spar cementation in shelter pores or molds, (3) saddle dolomite cementation, (4) anhydrite replacement, and (5) bitumen plugging. The basic pore types are primary shelter pores and secondary moldic pores. The reservoir has an excellent fluid-flow capacity.

The producing supra-mound interval (at a depth from 5,582 to 5,630 feet [1,701-1,716 $\mathrm{m}]$ ) is a dolomite with a packstone to grainstone fabric (figure 3-1). Framework grains consist of coated skeletal grains and pelloids. A significant fresh-water influence is indicated by the presence of degrading neomorphism and leaching. Dolomitization occurred in the mixing zone or from seepage reflux. There is some anhydrite plugging. The diagenetic events occurred in the following order: (1) degrading neomorphism, (2) dissolution, (3) early replacement dolomitization, (4) saddle dolomite cementation, and (5) anhydrite plugging. The basic pore types are primary interparticle pores and secondary moldic pores. The reservoir has excellent hydrocarbon storage and fluid-flow capacity, and is a candidate for $\mathrm{CO}_{2}$ flooding.

Blue Hogan field: The producing mud-rich, mound-core interval (at a depth from 5,412 to 5,446 feet $[1,650-1,600 \mathrm{~m}]$ ) in the Blue Hogan field is a limestone with a bafflestone fabric (figure 3-2). Framework grains consist of phylloid-algal plates with dolomite sphericals replacing utricules. The buildup represents a high-energy reef wall that resulted in pervasive early marine cementation throughout what originally had been rock with high porosity. There is some anhydrite replacement. The typical diagenetic events occurred in the following order: (1) first-generation micrite and fibrous isopachous, early marine cementation, (2) secondgeneration, botryoidal, early marine cementation, (3) third-generation, radiaxial, early marine cementation, (4) post-burial, replacement, rhombic dolomite cementation, (5) equant calcite cementation, and (6) anhydrite replacement. The basic pore types are primary shelter pores now filled with cement, and secondary moldic and channel pores. The reservoir has a moderate fluid-flow capacity. 
Heron North field: The producing platform-margin calcarenite interval (at a depth from 5,584 to 5,606 feet [1,702-1,709 m]) is a dolomite with a grainstone fabric (figures 3-3 and 3-17). Framework grains consist of mainly pelloids, surfacial ooids, and coated skeletal grains deposited in a high-energy, beach depositional environment. Classic fresh-water diagenesis or near-surface meteoric overprinting suggests early burial associated with an island. Dolomitization most likely resulted from seepage reflux. There is both anhydrite and bitumen plugging. The diagenetic events occurred in the following order: (1) degrading neomorphism, (2) dissolution by fresh water, (3) first-generation (early) replacement dolomitization (finegrained dolomite), (4) second-generation dolomitization (coarse-grained dolomite), anhydrite replacement and plugging, and (6) bitumen plugging. The basic pore types are secondary moldic, intercrystalline, micro-intercrystalline, and channel pores. The reservoir has an excellent hydrocarbon storage and fluid-flow capacity, and is a candidate for $\mathrm{CO}_{2}$ flooding.

Mule field: The producing mud-poor, mound-core interval (at a depth from 5,728 to 5,753 feet [1,746-1,753 $\mathrm{m}]$ ) is a limestone with a bafflestone fabric (figure 3-4). Framework grains consist of phylloid-algal plates and bryozoans. Some early marine cement and minor freshwater cements are present. There is both silica and anhydrite replacement. The typical diagenetic events occurred in the following order: (1) minor, fibrous isopachous (early) marine cementation, (2) minor dissolution and dog-tooth cementation by fresh water, (3) post-burial, equant, calcite cementation, (4) late, saddle dolomite cementation in molds replacing calcite cementation, (5) some silicification, and (6) anhydrite replacement. The basic pore types are primary shelter and interparticle pores, and secondary moldic pores. The reservoir has an excellent fluid-flow capacity.

The producing supra-mound interval (at a depth from 5,660 to 5,680 feet [1,725-1,731 $\mathrm{m}]$ ) is a dolomite with a skeletal packstone to grainstone fabric (figure 3-4). Framework grains consist of bryozoans and phylloid-algal plates. A heavy fresh-water influence is indicated by the presence of degrading neomorphism and leaching, often seen as a solution front. Dolomitization occurred in the mixing zone or from seepage reflux. There is some anhydrite cement and bitumen plugging. The diagenetic events occurred in the following order: (1) degrading neomorphism, (2) dissolution, (3) dog-tooth spar cementation, (4) early, replacement dolomitization, (5) plugging of pores by late dolomite, calcite, and anhydrite cementation, and (6) bitumen plugging. The basic pore types are secondary channel, moldic, intercrystalline, and micro-intercrystalline pores. The reservoir has a good hydrocarbon storage and fluid-flow capacity, and is a candidate for $\mathrm{CO}_{2}$ flooding.

Runway field: The bryozoan buildup interval (at a depth from 5,940 to 5,946 feet [1,810-1,815 $\mathrm{m}]$ ) is a limestone with a high-energy grainstone fabric (figure 3-5). Framework grains consist of bryozoans, crinoids, phylloid-algal plates, bivalves, forams, and clasts produced by brecciation. Some early marine cementation and mixing zone dolomitization (two generations) are present as well as anhydrite replacement. The typical diagenetic events occurred in the following order: (1) minor, early marine cementation, (2) dog-tooth and equant calcite cementation, (3) syntaxial cementation, (4) mechanical brecciation, (5) first-generation (early) dolomitization - medium-sized crystals, (6) second-generation (late) dolomitization - very coarse-sized crystals, (7) later, saddle dolomite cementation, and (8) anhydrite replacement. The basic pore types are primary interparticle pores; and secondary intercrystalline and moldic pores. The reservoir has a good fluid-flow capacity. 
The producing supra-mound interval (at a depth from 5,890 to 5,904 feet [1,795-1,800 $\mathrm{m}]$ ) is a dolomite (100 percent) with a grainstone fabric (figure 3-5). Framework grains consist of ooids, pelloids, grain aggregates, ostracods, and some phylloid-algal plates deposited in a high-energy, shallow-water to beach environment. A heavy fresh-water influence is indicated by the presence of degrading neomorphism and patchy dissolution. Dolomitization occurred in the mixing zone or from seepage reflux. The result is little cementation and a heterogeneous porosity development. The diagenetic events occurred in the following order: (1) degrading neomorphism and dissolution, (2) first-generation (early) dolomitization (finely crystalline), and (3) second-generation (late) dolomitization (coarsely crystalline). The basic pore types are secondary moldic, intercrystalline, micro-intercrystalline, and channel pores. The reservoir has good hydrocarbon storage and fliud-flow capacity, and is a candidate for $\mathrm{CO}_{2}$ flooding. 


\title{
CHAPTER IV OUTCROP AND MODERN RESERVOIR ANALOGUES
}

\author{
Thomas C. Chidsey, Jr.; Utah Geological Survey \\ David E. Eby; Eby Petrography \& Consulting, Inc. \\ Lisë Brinton; LithoLogic, Inc. \\ and \\ Kris Hartmann; Harken Southwest Corp.
}

\section{Outcrop Analogues}

Phylloid-algal buildups or mounds within the Paradox Formation are the major producers of oil and gas in the Paradox Basin. With the exception of the Greater Aneth field in southeastern Utah, most fields are small, ranging in size from 0.5 to 1 mile $(0.8-1.6 \mathrm{~km})$ wide and 0.5 to 4.5 mile $(0.8-7 \mathrm{~km})$ long. They consist of 1 to 8 wells at 20-, 40-, and 80-acre (8-, 16-, and 32-ha) spacing. The principal producing intervals are the Desert Creek and Ismay zones of the Paradox Formation with pay thickness ranging from 18 to 100 feet $(6-30 \mathrm{~m})$. At the reservoir production scale (less than 0.5 miles $[0.8 \mathrm{~km}]$ ), reservoir heterogeneity is the major cause of low recovery rates, particularly in the upper parts of the buildups.

Carbonate buildups, exposed in outcrops of the Paradox Formation along the San Juan River of southeastern Utah, provide production-scale analogues of reservoir-facies characteristics, geometry, distribution, and the nature of boundaries contributing to the overall heterogeneity of these reservoirs. Algal buildups in the Ismay zone are exposed at river level 17 miles $(27 \mathrm{~km})$ west of Bluff, Utah, and continue up a northeast-trending tributary canyon on the south side of the river, informally named Wild Horse Canyon (figure 4-1). High-resolution, outcrop-based sequence-stratigraphic analysis has been conducted on these rocks by Goldhammer and others (1991, 1994), Simo and others (1994), Best and others (1995), Weber, Sarg, and Wright (1995), Weber, Wright, and others (1995), Gianniny and Simo (1996), and Grammar and others (1996).

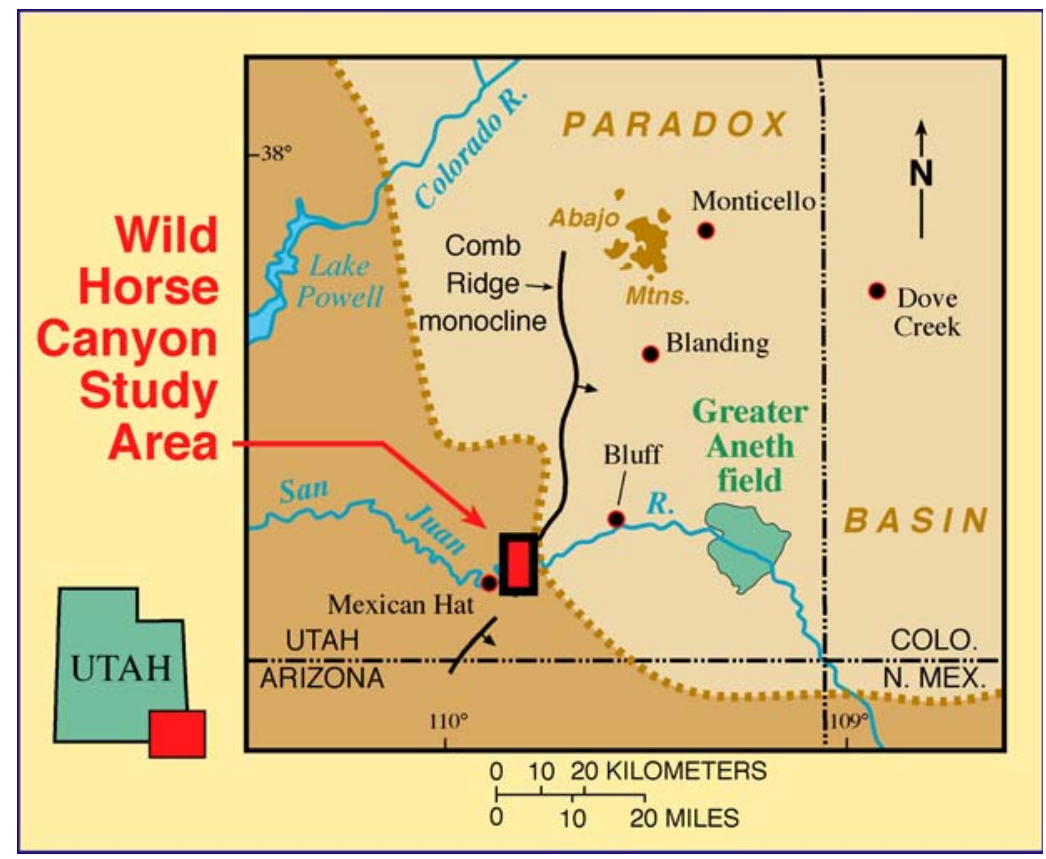

Figure 4-1. Location of Paradox Formation outcrops in the Wild Horse Canyon area along the San Juan River, southeastern Utah. 
The goal of this project task was to examine a single, small but representative mound complex within a 5th-order sequence-stratigraphic cycle as an analogue for Ismay and Desert Creek reservoirs in the eastern part of the Paradox Basin. The specific objectives were to: (1) increase understanding, at a reservoir production scale, of vertical and lateral facies variations and relationships within phylloid-algal buildups; (2) describe the lithologic characteristics associated with each buildup facies; (3) determine buildup morphology, internal geometries, and possible permeability and porosity distributions; and (4) identify potential impediments and barriers to fluid flow within the mound complex.

An outcrop-analogue model, combined with the details of internal lithofacies characteristics, can be used as a "template" for evaluation of data from conventional core, geophysical and petrophysical logs, and seismic surveys. When combined with subsurface geological and production data, the analogue model will improve development drilling and production strategies, reservoir-simulation models, reserve calculations, and design and implementation of secondary/tertiary oil recovery programs in the small fields of the Paradox Basin and elsewhere.

\section{Methods}

Quantitative data gathered from several selected outcrops was evaluated. These data included: (1) the sizes, shapes, orientations, and stratigraphic positions of units within the mounds, (2) facies relationships, and (3) gross reservoir properties of the key mound storage units, flow units, and permeability barriers. The work involved interpretation and analyses of: (1) numerous outcrop photomosaics, (2) stratigraphic sections, (3) the areal extent of the mounds and associated facies, and (4) representative petrographic thin sections. Photomosaics were generated from digitized, oblique, outcrop photographs using image-editing software. The photomosaics consist of joined, distortion-corrected images. Scale of the photos was determined in the field by measuring locatable horizontal and vertical points on the photograph. The photomosaics were then annotated with distinct unit, facies, and flooding surface boundaries (figure 4-2). Major elements of reservoir architecture, lateral variations in reservoir properties, and definition of an internal "representative elementary volume" in each key facies were particularly emphasized by the project team for use in later reservoir modeling of fluid storage and flow.

\section{Interpretation of Mound Morphology and Composition}

Morphologically, algal buildups within the Ismay zone of the Paradox Formation consist of large, northwest-trending algal banks separated by interbank troughs or channels. Smaller, secondary, algal mounds and intermounds define the upper surfaces of the algal banks. Cyclic sedimentation is recorded by four dominant facies recognized in a single, shoaling-upward sequence: (1) substrate carbonate, (2) phylloid algal, (3) intermound, and (4) skeletal capping (Brinton, 1986; Grammar and others, 1996). An outcrop in the Wild Horse Canyon area displaying these and additional facies was selected for detailed study (figure 4-3A) (Chidsey, Brinton, and Eby, 1996). 

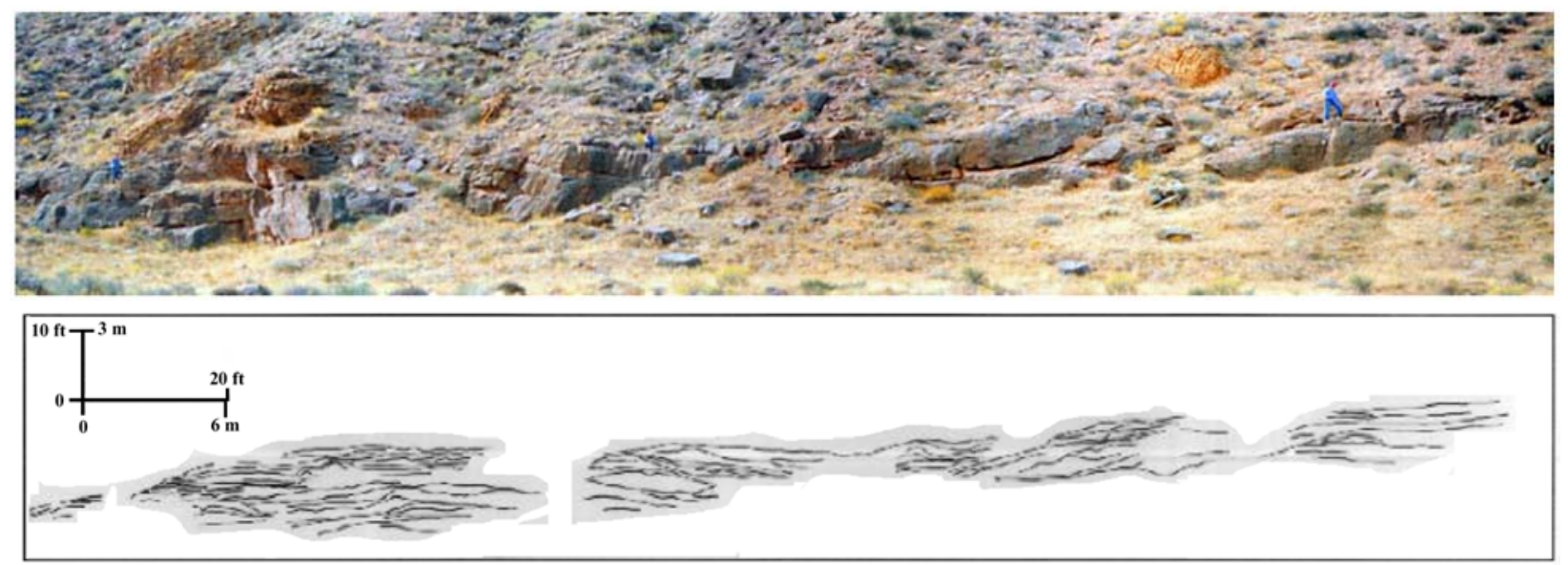

Figure 4-2. Photomosaic, view to the west, and interpretation below showing bedding planes of the phylloid-algal mound complex of the lower Ismay zone in Wild Horse Canyon, near the San Juan River, Utah (from Chidsey, Brinton, and Eby, 1996). Note the large trough right of center

Figure 4-3. Outcrops in the Ismay zone of the Paradox Formation, Wild Horse Canyon near the San Juan River, southeastern Utah. (A) Typical phylloid mound composed of algal bafflestone, skeletal grainstone, and packstone. A flooding surface is present at the top of the mound. (B) Cement-rich algal bafflestone exposed in a phylloid mound. Original sheltered pore spaces were filled with mud; cement rinds are developed around algal plates.
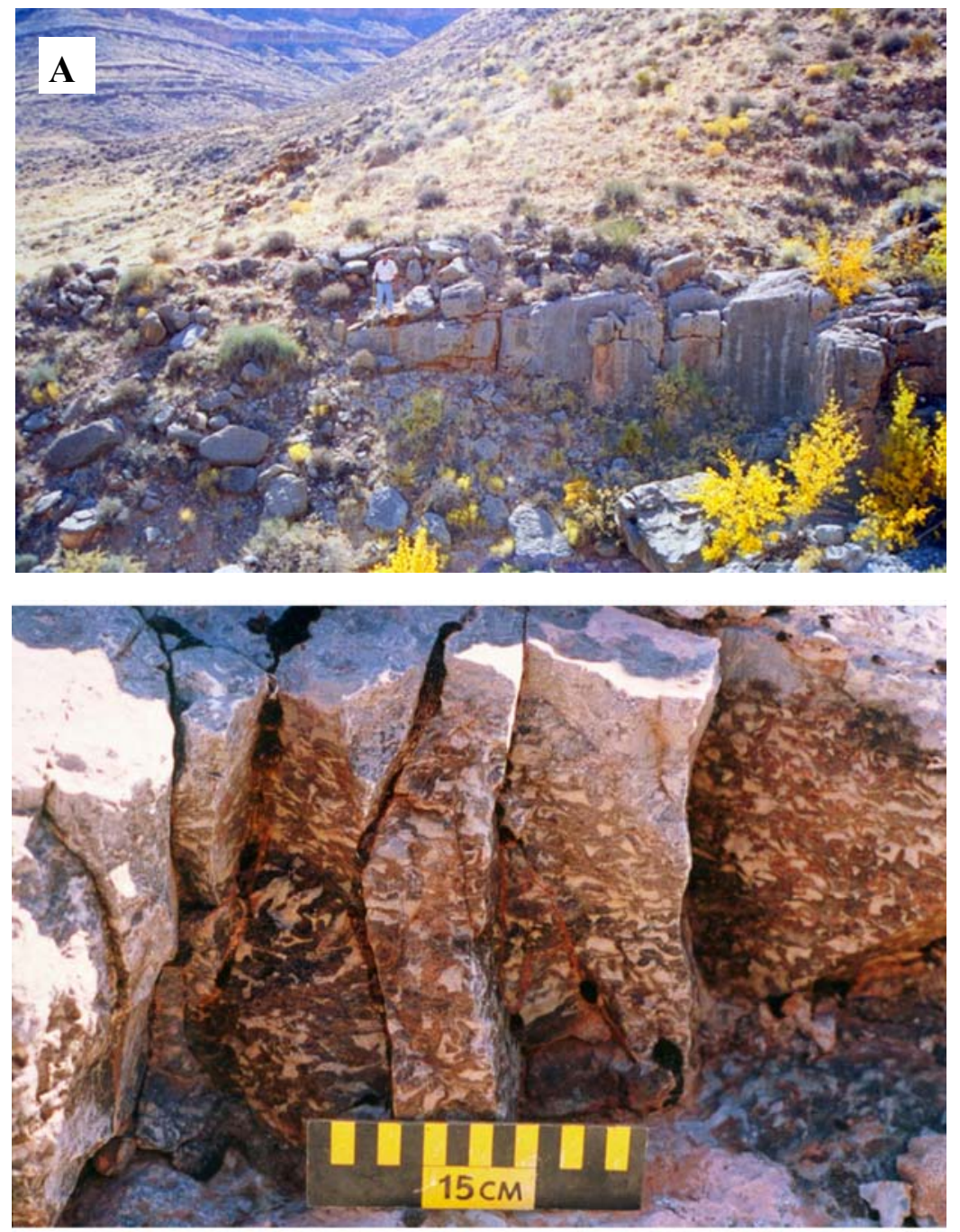
The Wild Horse Canyon study site is interpreted as consisting of three principal features: (1) a phylloid-algal mound with grainstone buildups deposited at or near sea level, (2) a "reef wall" that formed in a higher energy, more marginal setting than the mound, and (3) a carbonate detrital wedge and fan consisting of shelf debris. Hypothetical facies relationships are illustrated in the schematic block diagram (figure 4-4). This interpretation is not only based on observations made at the outcrop, but also incorporates subsurface core data which are documented and discussed in Chidsey, Eby, and Lorenz (1996).

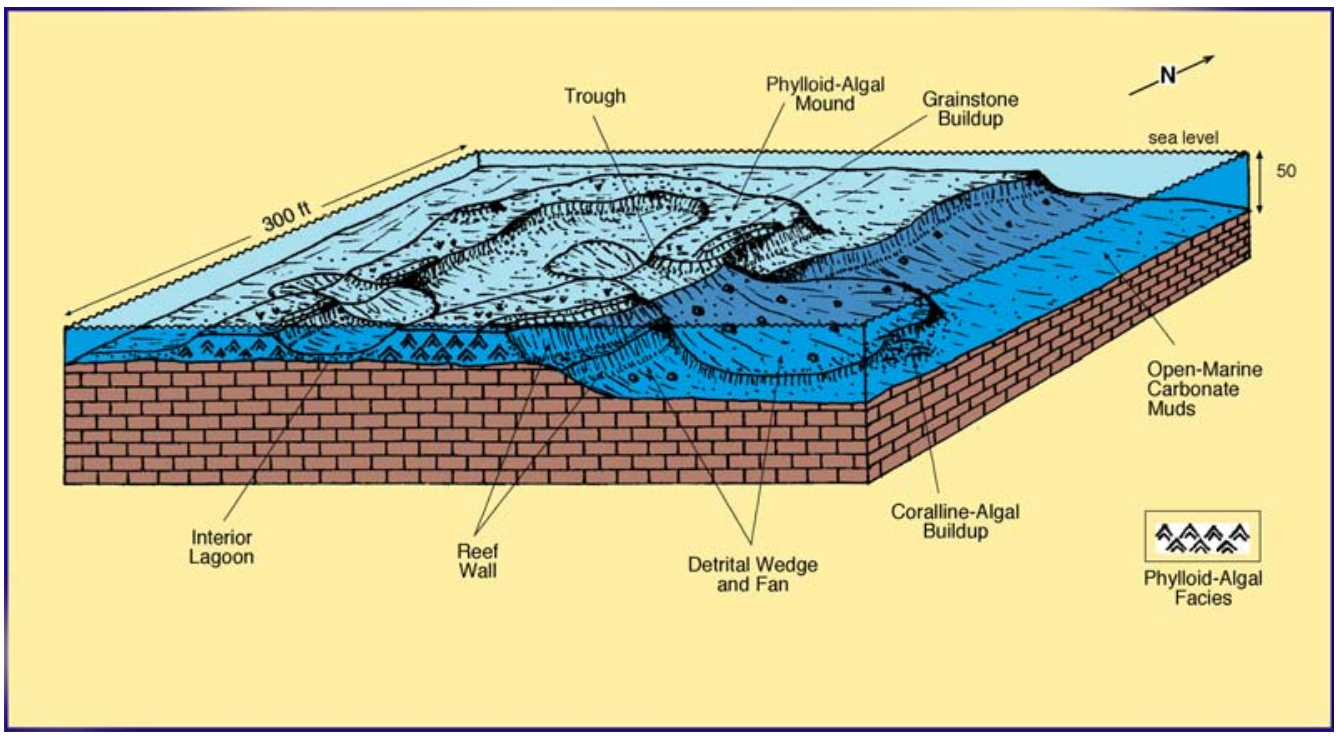

Figure 4-4. Block diagram displaying depositional interpretation of Wild Horse Canyon mound complex and associated features (from Chidsey, Brinton, and Eby, 1996). This interpretation is a composite of inferences made from outcrop and subsurface data.

Bafflestone and Chaetetes- and rugose-coral-bearing grainstone and packstone textures observed in the northern part of the Wild Horse Canyon complex comprise the main phylloidalgal mound (figure 4-3B). A texturally and compositionally similar algal buildup constitutes the primary reservoir facies in oil and gas fields to the east of the study site. A flooding surface recognized on top of the buildup in outcrop and probable low-permeability lithotypes (packstone and cementstone) within the buildup might act as barriers or baffles to fluid flow in the subsurface. The Wild Horse Canyon outcrop appears to be only a portion of a larger algalbank complex, or one of a series observed in the San Juan Canyon. Although not documented at this outcrop locality, observations from core in similar areas in the subsurface suggest an interior-lagoon and other associated facies likely formed west of the study area as part of this complex (Chidsey, Eby, and Lorenz, 1996).

The rudstone, cementstone, and lumpstone depositional textures represent deposits which were part of, or near, what might be interpreted as a "reef wall" (figure 4-4). The presence of internal sediments in these rocks indicates an influx of mud during storms or mud routinely distributed by stronger currents. The reef wall records deposition and intense seafloor cementation as a result of reflux of large pore volumes of water through sediments occupying a high-energy marginal setting between shallow-shelf and deeper, open-marine conditions. The reef wall may have served as a barrier behind which algal buildups could 
develop and thrive in a more protected setting that facilitated preservation of primary shelter porosity. The presence of reef-wall facies in a well core might serve as a proximity indicator for a more prospective drilling target. Examples of this relationship have been observed in the Blue Hogan and Brown Hogan fields, southwest of the Greater Aneth field (Chidsey, Eby, and Lorenz, 1996).

An intermound trough in the center of the mound could represent a tidal channel flowing across the reef wall (figure 4-4). Material shed from the mound and reef wall and subsequently carried through the tidal channel might have been deposited as a detrital wedge or fan on open-marine carbonate muds. These features are recorded by the grainstone and transported material observed in outcrop on the east side of the complex. Coralline-algal buildups may have also developed near the carbonate detrital fan, but were not observed at this locality in the canyon. Reservoir-quality porosity may have developed in troughs, detrital wedges, and fans identified from core and facies mapping. If these types of deposits are in communication with mound-reservoir facies in the subsurface, they could serve as conduits facilitating sweep efficiency in secondary/tertiary recovery projects. However, the relatively small sizes and the abundance of intermound troughs over short distances, as observed along the river exposures, suggests caution should be used when correlating these facies between development wells. Facies that appear correlative and connected from one well to another may actually be separated by low-permeability facies which inhibit flow and decrease production potential.

\section{Study Results}

The results of these field investigations were incorporated as the geological constraints on facies distributions in the geostatistical models. Reservoir models were developed for possible water and $\mathrm{CO}_{2}$ floods of small Paradox Basin fields to determine the most effective secondary/tertiary recovery method. The models include lithologic fabrics, flooding surfaces, and inter-mound troughs, based on the mound complex exposed at Wild Horse Canyon.

\section{Modern Analogues}

The oil production in the circum-Aneth area of the Paradox Basin is from shallow-shelf carbonate buildups in the Desert Creek zone of the Paradox Formation. These buildups were deposited within a variety of depositional environments in spite of their proximity to each other, as observed from the regional facies belts map (figure 2-1). Further study shows these Pennsylvanian environments have modern analogues near the coasts of Florida, Australia, and the Bahamas (Chidsey and Eby, 2000a). Understanding these facies and depositional patterns within the basin and their modern analogs helped to: (1) estimate reservoir heterogeneity and capacity, and (2) identify areas that have the greatest petroleum potential (Chidsey and Eby, 2000b).

The Paradox Formation was deposited in a warm, often restricted, shallow sea in the rapidly subsiding Paradox Basin. The relatively undeformed circum-Aneth area developed on a shallow-marine shelf that locally contained algal-mound and other carbonate buildups in a subtropical climate (figure 2-2). We recognize three regional facies belts from our evaluation of case-study fields, cores from exploratory wells, and outcrops: (1) open-marine, (2) shallowshelf/shelf-margin, and (3) intra-shelf/salinity-restricted facies. Specific modern analogues for 
each of these deposits have been identified.

The open-marine facies belt includes carbonate buildups (typically crinoid-rich mounds), crinoidal and brachiopod-bearing carbonate muds, euxinic black shales, wall complexes, and detrital fans. Modern deposits can be found in the deep waters of the western Great Bahama Banks and Straits of Florida.

The shallow-shelf/shelf-margin facies belt includes carbonate buildups (phylloid-algal [figure 4-5], coralline-algal, and bryozoan mounds), calcarenites (island beach, stabilized grain flats, and offshore sand banks), and platform-interior carbonate muds and sands. Similar kinds of buildups or mounds can be observed in Florida Bay (figures 4-6 and 4-7). Mud bank islands, built up by turtle grass (Thalassia), are beautifully displayed and are roughly the same size and shape as many of the small oil fields in the Paradox Basin (figures 4-8 and 4-9). Space shuttle astronauts get an excellent view of island beaches and offshore sandbanks in a warm shallow sea when they pass over Schooner Cays along the Great Bahama Bank (figure 4-10).

The intra-shelf/salinity-restricted facies belt represents small sub-basins within the shallowshelf/shelf-margin facies belt, and includes evaporites. The limited circulation of open-ocean seawater within these warm, very shallow shelf areas resulted in the deposition of tidal-flat muds, bioclastic lagoonal muds, tidal-channel carbonate sands and stromatolites, euxinic dolomites, and evaporitic salt and anhydrite (figure 4-11, inset). Similar deposits occur in Sharks Bay on the western coast of Australia (figure 4-11). Sharks Bay is a similarly shallow area with a restricted flow of water to and from the Indian Ocean that makes the water there extra saline.

Carbonate buildups, tidal-channel carbonate sands, and other features can appear as promising seismic anomalies. However, if these buildups are located within either the open-marine or intra-shelf/salinity-restricted facies belts, the reservoir quality is typically poor. Buildups and calcarenites in shallow-shelf/shelf-margin facies can have excellent reservoir properties.

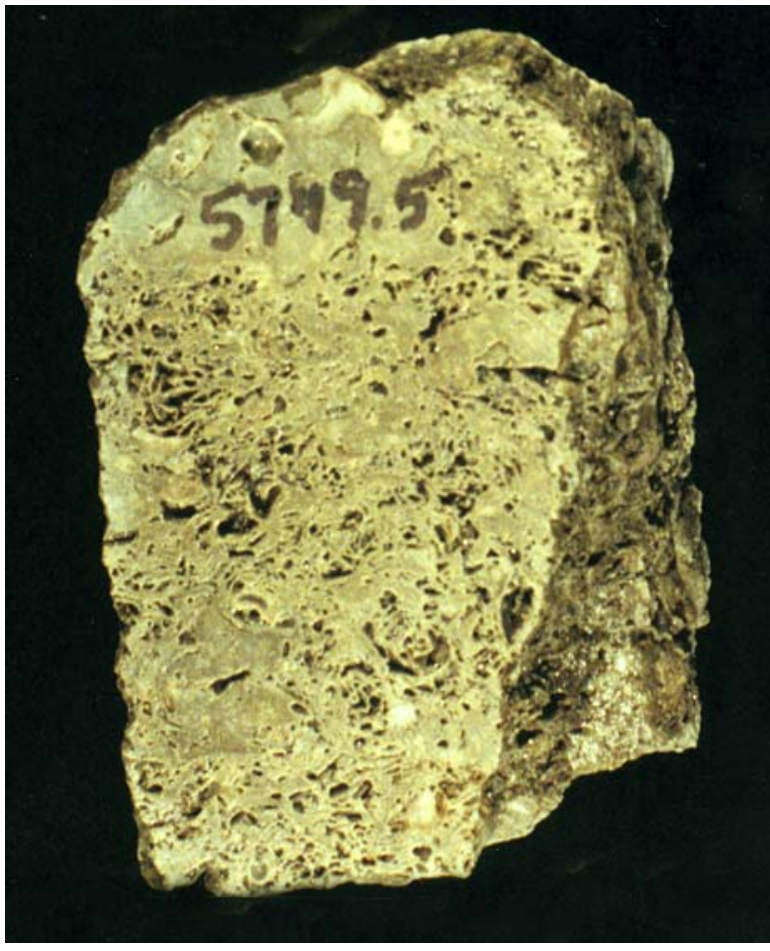

Figure 4-5. Phylloid-algal bafflestone in core of the producing oil reservoir rock from Mule field, San Juan County, Utah.

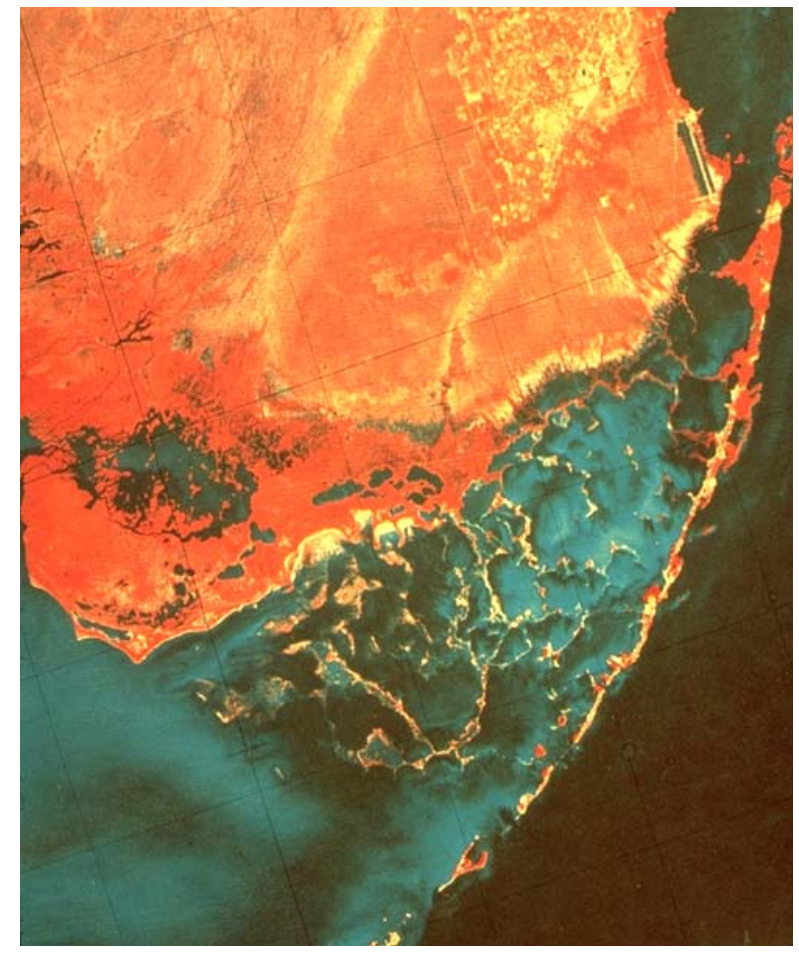

Figure 4-6. Satellite image of Florida Bay (Scholle and James, 1995). Reproduced courtesy of SEPM (Society for Sedimentary Geology). 


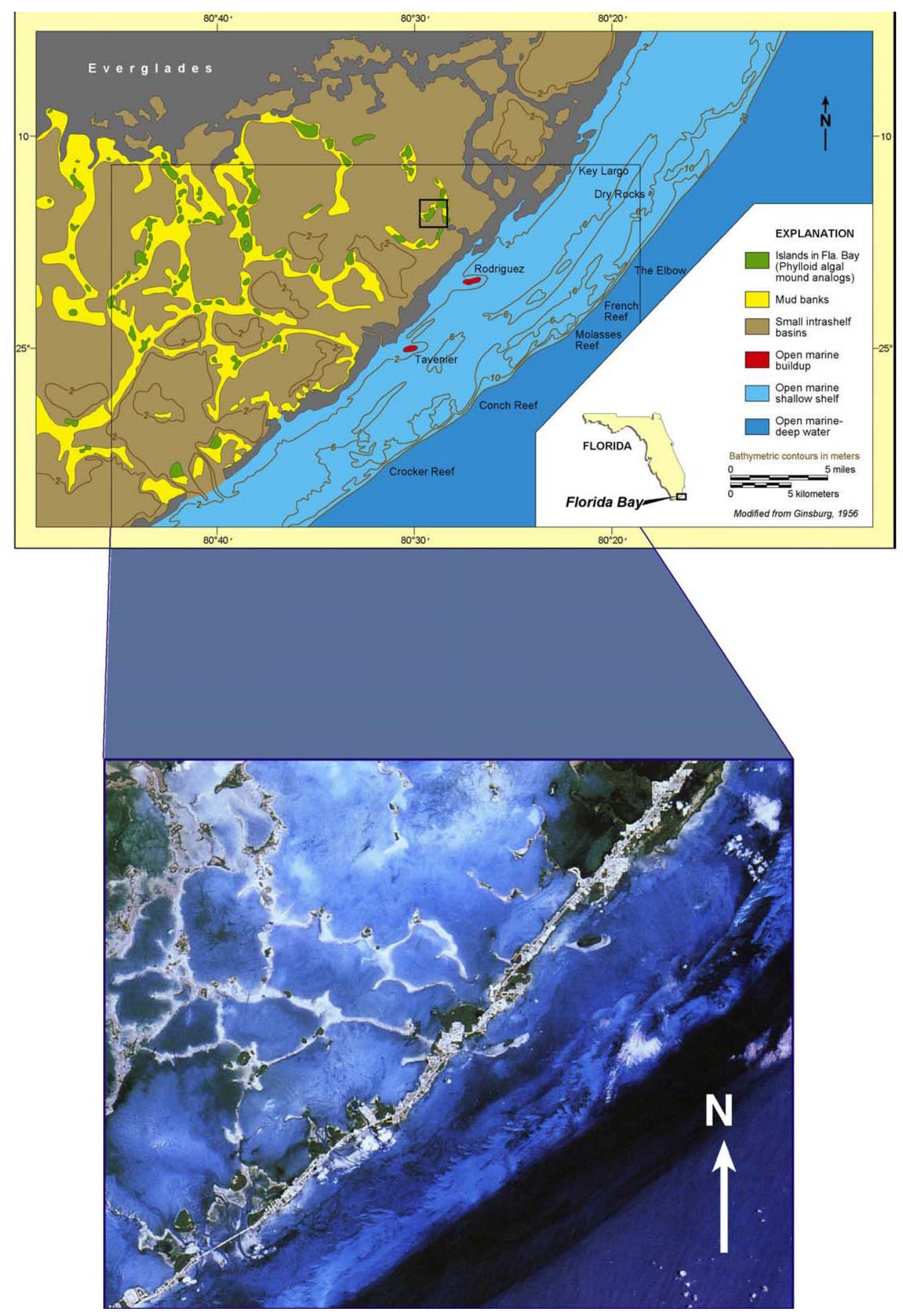

Figure 4-7. Depositional environments of Florida Bay (modified from Ginsburg, 1956; Harris, 1994). AAPG (C 1994, reprinted by permission of the AAPG whose permission is required for further use. 


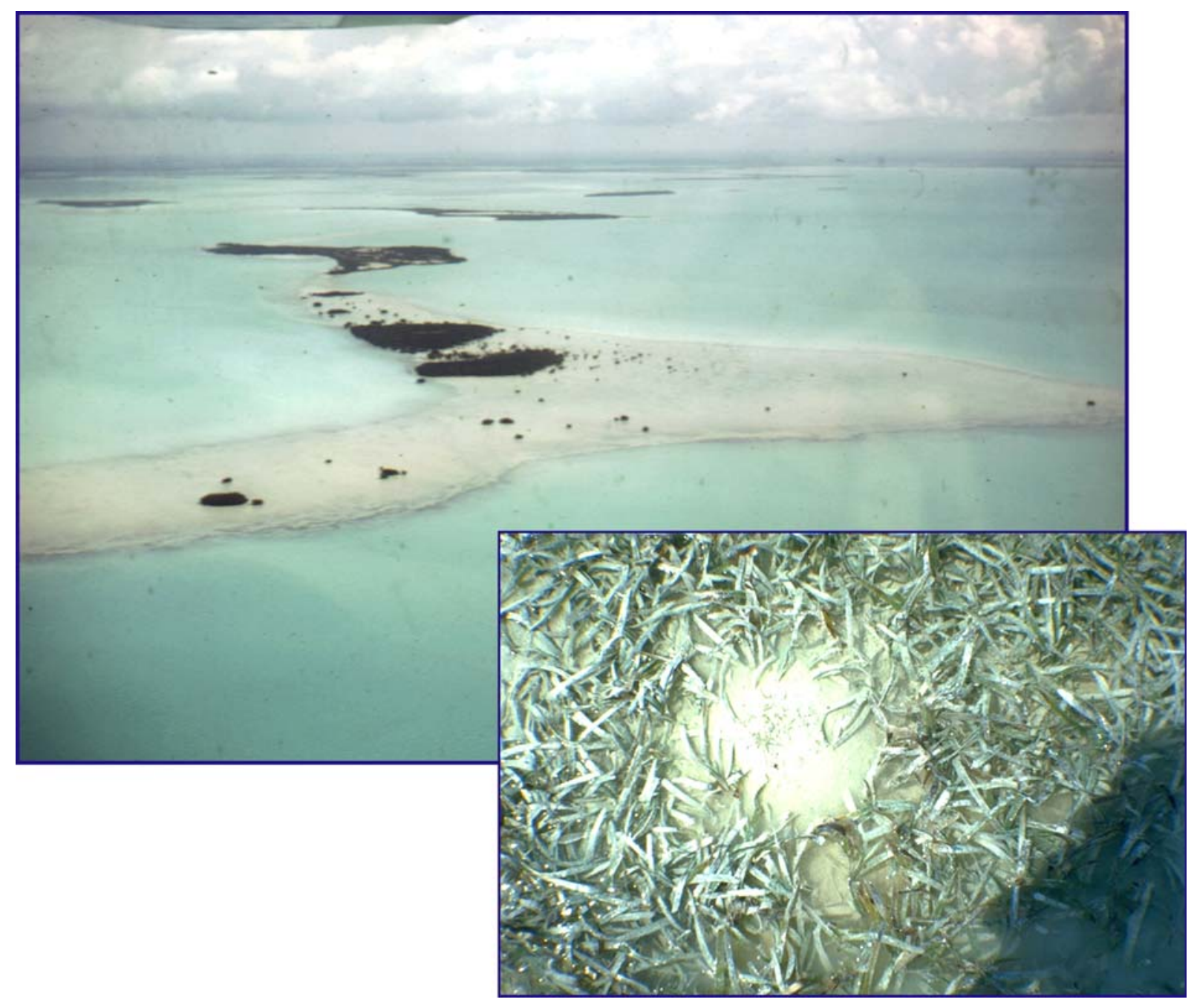

Figure 4-8. Islands along Florida Bay mud banks; inset - turtle grass Thalassia (photos by David E. Eby, Eby Petrography \& Consulting, Inc.). 


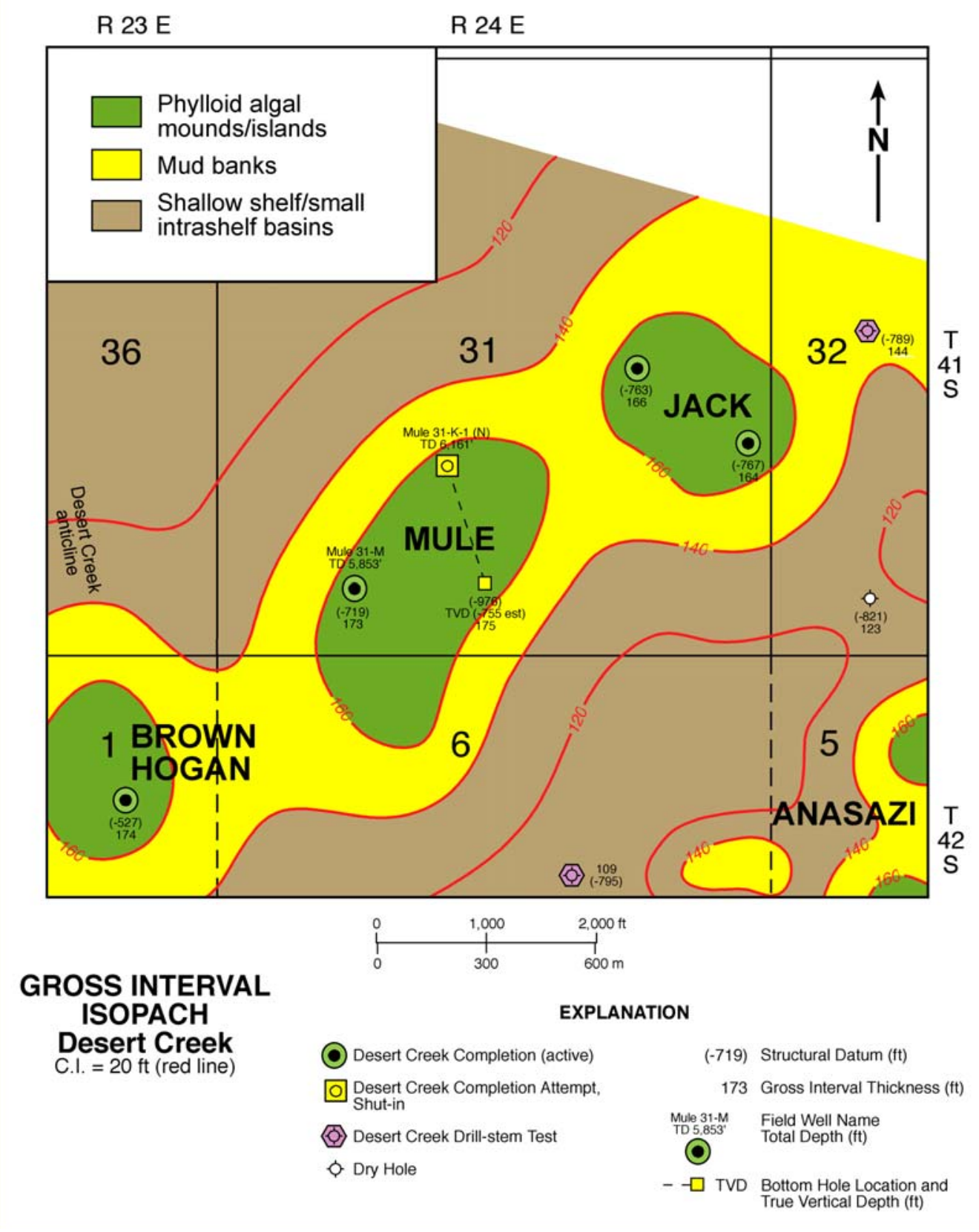

Figure 4-9. Depositional facies of Mule, Brown Hogan, Jack, and Anasazi fields, Paradox Basin, Utah. 


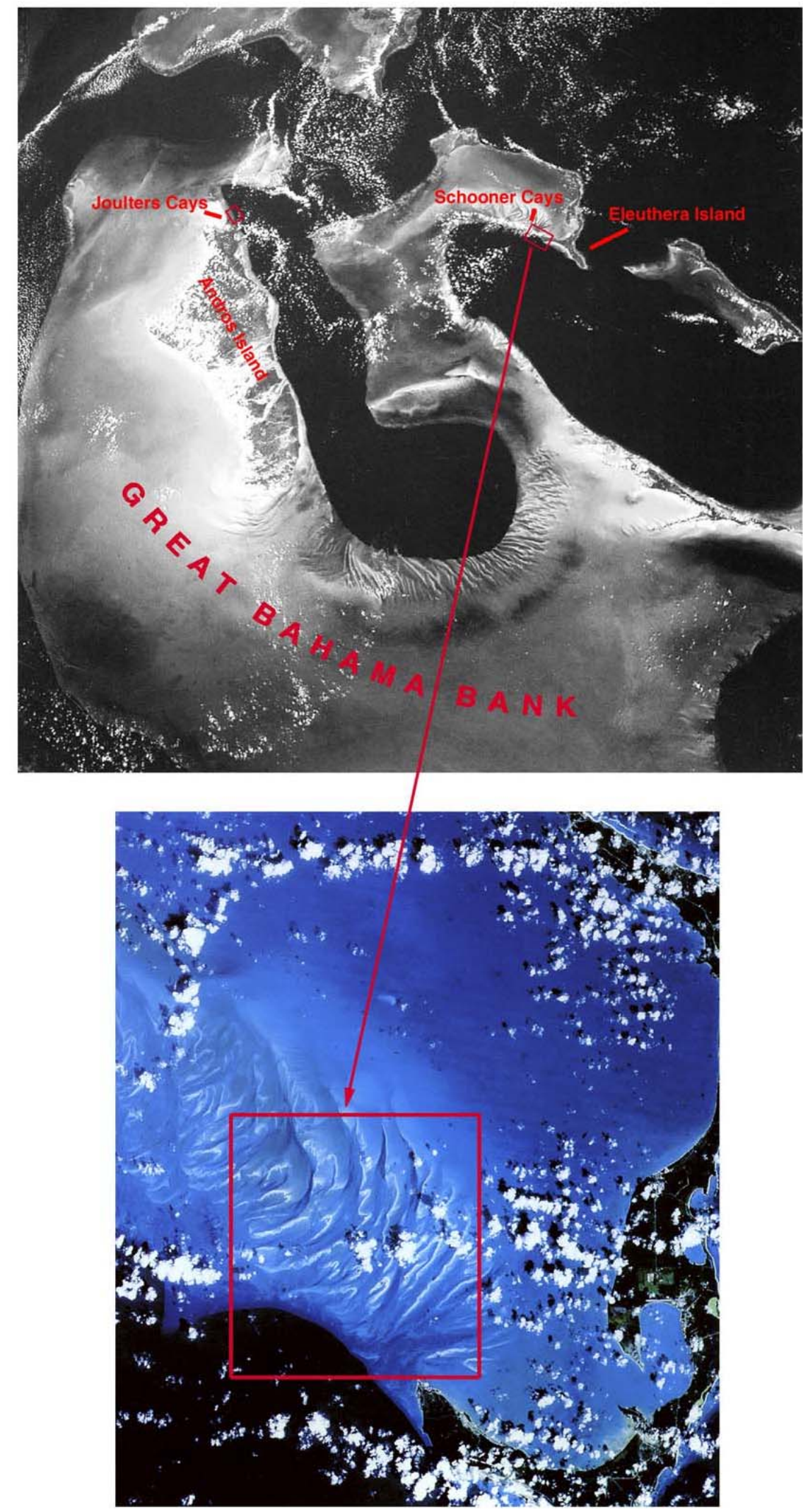

Figure 4-10. Shallow marine sandbanks, Schooner Cays; satellite image of the Great Bahama Bank (modified from Harris and Kowalik, 1994). $A A P G$ (C) 1994, reprinted by permission of the AAPG whose permission is required for further use. 


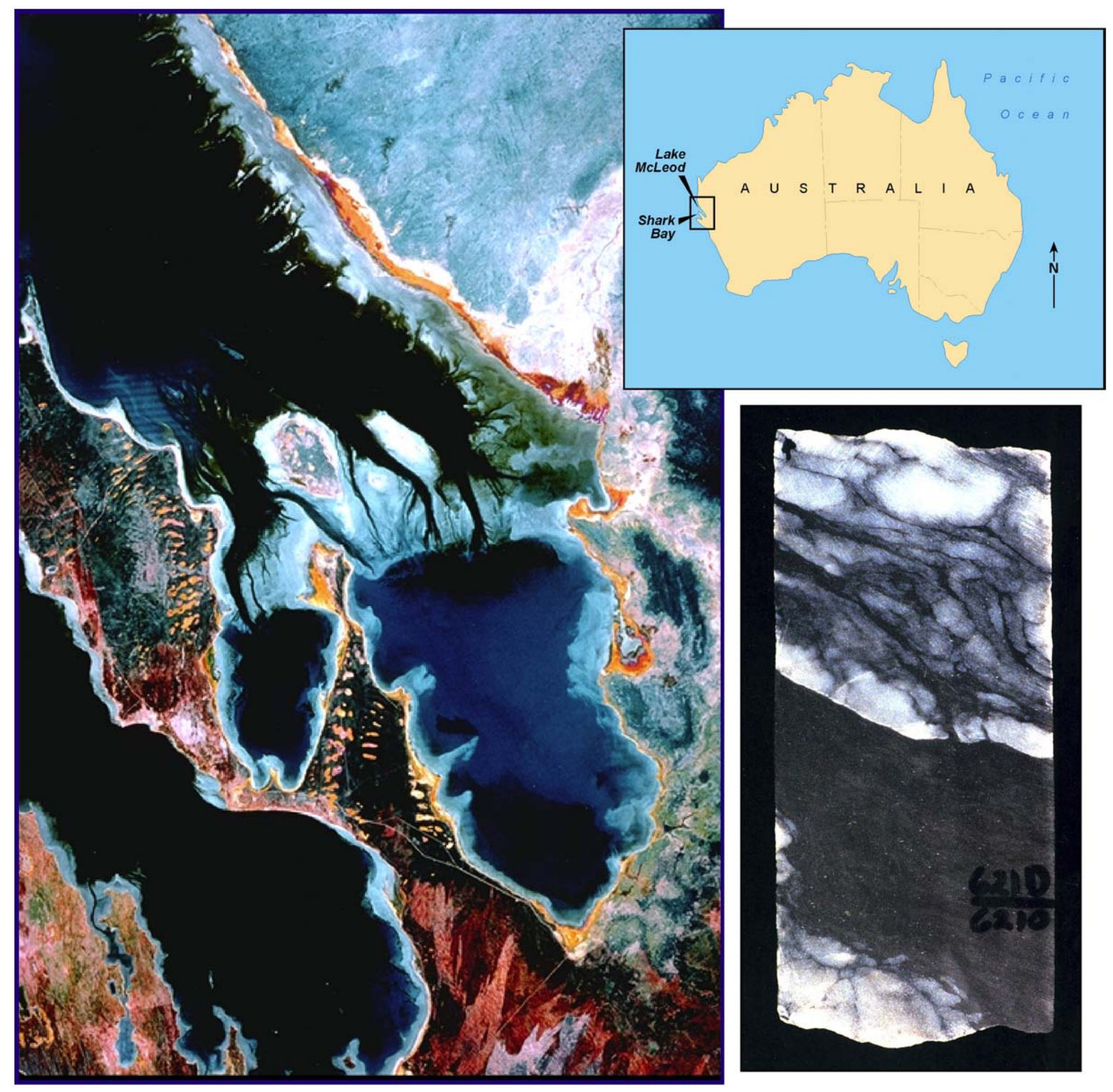

Figure 4-11. Inset - Bedded anhydrite and dense, black muddy limestone, from a core of the Coral No. 11A-1 wildcat well, San Juan County, Utah; satellite image of Shark Bay, western coast of Australia (modified from Scholle and James, 1996). Reproduced courtesy of SEPM (Society for Sedimentary Geology). 


\title{
CHAPTER V \\ PROJECT DRILLING AND SEISMIC PROGRAMS
}

\author{
Thomas C. Chidsey, Jr.; Utah Geological Survey \\ and \\ Marshall Watson, Wilson Groen, and Kris Hartmann; Harken Southwest Corp.
}

\section{Drilling Rationale}

A team of geologists, reservoir engineers, and geophysicists from Harken evaluated potential development locations for the project fields. Project development wells are designed to increase the well density from 80 acres (32.3 ha) per well to 30 to 40 acres (12-16 ha) per well. During the project, one development well was drilled in the Anasazi field and a horizontal lateral was extended from the Mule No. 31-K-1 (N) well in Mule field (figure 1-1). The length and orientation of the lateral was determined by completion and evaluation of the new seismic data.

The data obtained from these new wells enabled the project team to assess: (1) the frequency of reservoir compartment changes (reservoir heterogeneity) in a given area, (2) the amount of communication between compartments, (3) how a waterflood or $\mathrm{CO}_{2}$ flood might flow from one compartment to another, and (4) the areal extent of an average compartment. The following new well information was used in the geologic and reservoir characterization:

1. more accurate descriptions of the general reservoir geology and reservoir compartmentalization/continuity,

2. pressure data in drawn down areas from current producers,

3. wettability and relative permeability data from fresh cores,

4. pressure transient data to determine communication with other fields (determine communication with adjacent reservoirs previously thought separate), and

5. increased data for the reservoir simulation history match to allow for better construction of models used in $\mathrm{CO}_{2} /$ water flood simulations.

\section{Anasazi No. 6H-1 Well, Anasazi Field}

The first project development well, the Anasazi No. 6H-1, was spudded on May 20, 1995 and drilled to a total depth of 5,826 feet $(1,776 \mathrm{~m})$ in the Anasazi field, SE1/4NE1/4 section 6, T. 42 S., R. 24 E., Salt Lake Base Line (SLBL) (figure 1-1). The principal reservoir evaluated, a carbonate buildup in the Desert Creek zone of the Paradox Formation, was penetrated at 5,624 feet $(1,714 \mathrm{~m})$. The buildup was cored (120 feet [37 m] of conventional core recovered) and described. Geophysical logs run consisted of the dual laterolog, spectral density, dual-spaced neutron, gamma ray, and long-spaced sonic. The wireline formation tester obtained reservoir pressures throughout the Desert Creek zone ranging from 300 to 1,200 
pounds per square inch (psi [2,069-8,274 kpa]). The main pay intervals held 15 to 25 percent of the original reservoir pressure.

The Anasazi No. 6H-1 well was completed on September 15, 1995 for an IPF of 31.3 $\operatorname{BOPD}\left(5.0 \mathrm{~m}^{3} / \mathrm{d}\right), 25 \mathrm{MCFGPD}\left(708 \mathrm{~m}^{3} / \mathrm{d}\right)$, and $7.5 \mathrm{bbls}\left(1.2 \mathrm{~m}^{3}\right)$ of water per day in the Desert Creek and Ismay zones. A grainstone/packstone interval in the Desert Creek zone was perforated from 5,723 to 5,730 feet $(1,744-1,746 \mathrm{~m})$ and acidized with 350 gallons (gal [1,325 L]) of 15 percent hydrochloric acid $(\mathrm{HCl})$. The resulting test indicated the pressure and permeability in the interval were too low to yield any meaningful data. A dolomite interval in the upper section of the Desert Creek was perforated from 5,680 to 5,694 feet (1,731-1,735 m). This interval was subsequently acidized with 30 gal $(114 \mathrm{~L})$ of $\mathrm{HCl}$ and swab tested for 2 $\operatorname{BOPD}\left(0.3 \mathrm{~m}^{3} / \mathrm{d}\right)$. After the swab test, a 200-hour pressure buildup test was run. A skin factor and permeability of +13 and 1.2 millidarcies (md) respectively were derived from the pressure buildup test. Because of the high skin damage, the zone was re-acidized. Several additional intervals were perforated and acidized including the upper Ismay zone from 5,526 to 5,531 feet $(1,684-1,686 \mathrm{~m})$. Production facilities were installed and the well flow rate stabilized at 17 BOPD $\left(3 \mathrm{~m}^{3} / \mathrm{d}\right)$ from a gross perforated Desert Creek interval of 5,664 to 5,741 feet $(1,726$ $1,750 \mathrm{~m})$ and a Ismay interval of 5,526 to 5,531 feet (1,684-1,686 m).

Selected plugs from the reservoir were used to determine oil/water and gas/oil relative permeability (see Chapter VII, Engineering Reservoir Characterization of the Carbonate Reservoir in the Desert Creek Zone). Pressure buildup tests were used to determine average reservoir pressure, boundaries, and flow properties. Fluid samples taken from these intervals were used for extensive compositional studies. These data were incorporated into the Anasazi reservoir flow-simulation model.

Conventional core was obtained from the Desert Creek zone of the Anasazi $6 \mathrm{H}-1$ well. Evaluation of the core suggests the well missed the main buildup or mound-core interval (algal bafflestone reservoir) and penetrated poorer quality mound-flank deposits (mixed carbonate fabrics that are brecciated, slumped, and chaotic). However, the dolomites in the upper part of the buildup or supra-mound may be connected to the upper Anasazi reservoirs in the rest of the field. As of January 1, 2002 the Anasazi $6 \mathrm{H}-1$ well has produced 23,172 BO (3,684 $\left.\mathrm{m}^{3}\right)$ and 62 million cubic feet of gas (MMCFG [1.8 million $\mathrm{m}^{3}$ ) (Utah Division of Oil, Gas and Mining, 2002).

\section{New Seismic Data and Horizontal Drilling, Mule Field}

\section{Seismic Acquisition}

The Mule field (figure 1-1) was identified in 1990 as a seismic anomaly indicating a carbonate buildup in the Desert Creek zone (figure 3-11). The Mule No. 31-K-1 (N) discovery well (SE1/4SW1/4 section 31, T. 41 S., R. 24 E., SLBL) was deviated about 1,140 feet (347 m) south-southeast, avoiding topographic problems and a highway, to encounter what was thought to be the main part of the buildup (figure 3-9). However, as described earlier, the well encountered mound-flank deposits. The Mule No. 31-M offset well (SW1/4SW1/4 section 31, T. 41 S., R. 24 E., SLBL) encountered a thick mound-core interval.

A new seismic program was permitted and conducted in 1996 over the Mule field area. The additional seismic data were used to determine the extent of the algal mound buildup in the field and the orientations and lengths of any horizontal development drilling. Five miles $(8 \mathrm{~km})$ 
of two-dimensional swath seismic data were generated along northeast-southwest lines across the Mule area (figure 5-1). These seismic data were interpreted and incorporated into the overall interpretation of the southwest Aneth region. The following isochron maps were constructed: Ismay zone to Desert Creek zone (figure 5-2), Desert Creek zone to Akah zone, and Ismay zone to Gothic shale. These maps indicate the Mule field is a lenticular, south- to northeast-trending, linear mound with additional reservoir potential on strike to the northeast of the Mule No. 31-M well. Harken Southwest Corporation, the field operator, determined the most economical way to penetrate a significant portion of this potential mound buildup was to re-enter the Mule No. 31-K-1 (N) well and drill horizontally in a northwest direction.

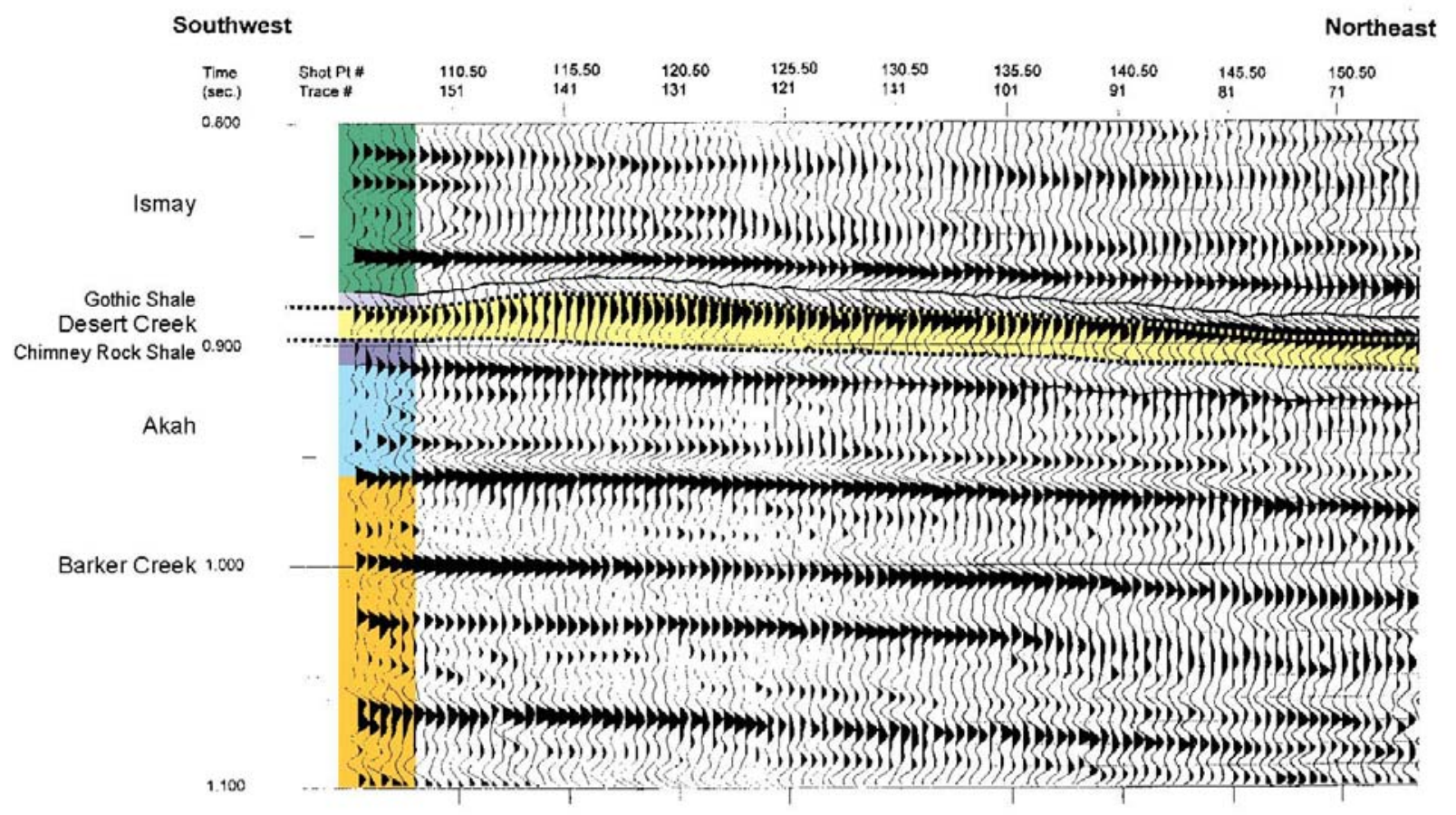

Figure 5-1. Southwest-northeast migrated seismic line (Mule 300) defining the Mule field algal mound buildup. Traces per inch $=20$; inches per second $=10 ; 0.900$ second is approximately 5,850 feet $(1,783 \mathrm{~m})$ (see figure 5-2 for seismic line and shot-point locations).

\section{Horizontal Sidetrack}

The Mule No. $31 \mathrm{~K}-1$ sidetrack was the first horizontal test of a small, algal buildup in the Paradox Basin (figure 5-3). The sidetrack began at a measured depth (MD) of 6,029 feet $(1,838 \mathrm{~m})$ and drilled to a MD of 7,044 feet $(2,147 \mathrm{~m})(5,807$ feet $[1,770 \mathrm{~m}]$ true vertical depth) with a horizontal displacement of 939 feet $(286 \mathrm{~m})$. Well cuttings and the mud $\log$ (no geophysical logs were run) indicate the following (the general interpretation is shown on figure 5-4):

(1) Forty-five vertical feet (14 m) of anhydrite was encountered at the top of the Desert Creek zone or above the supra-mound interval of the buildup facies. This compares to 25 feet $(7.6 \mathrm{~m})$ of anhydrite in the Mule No. 31-M well. 


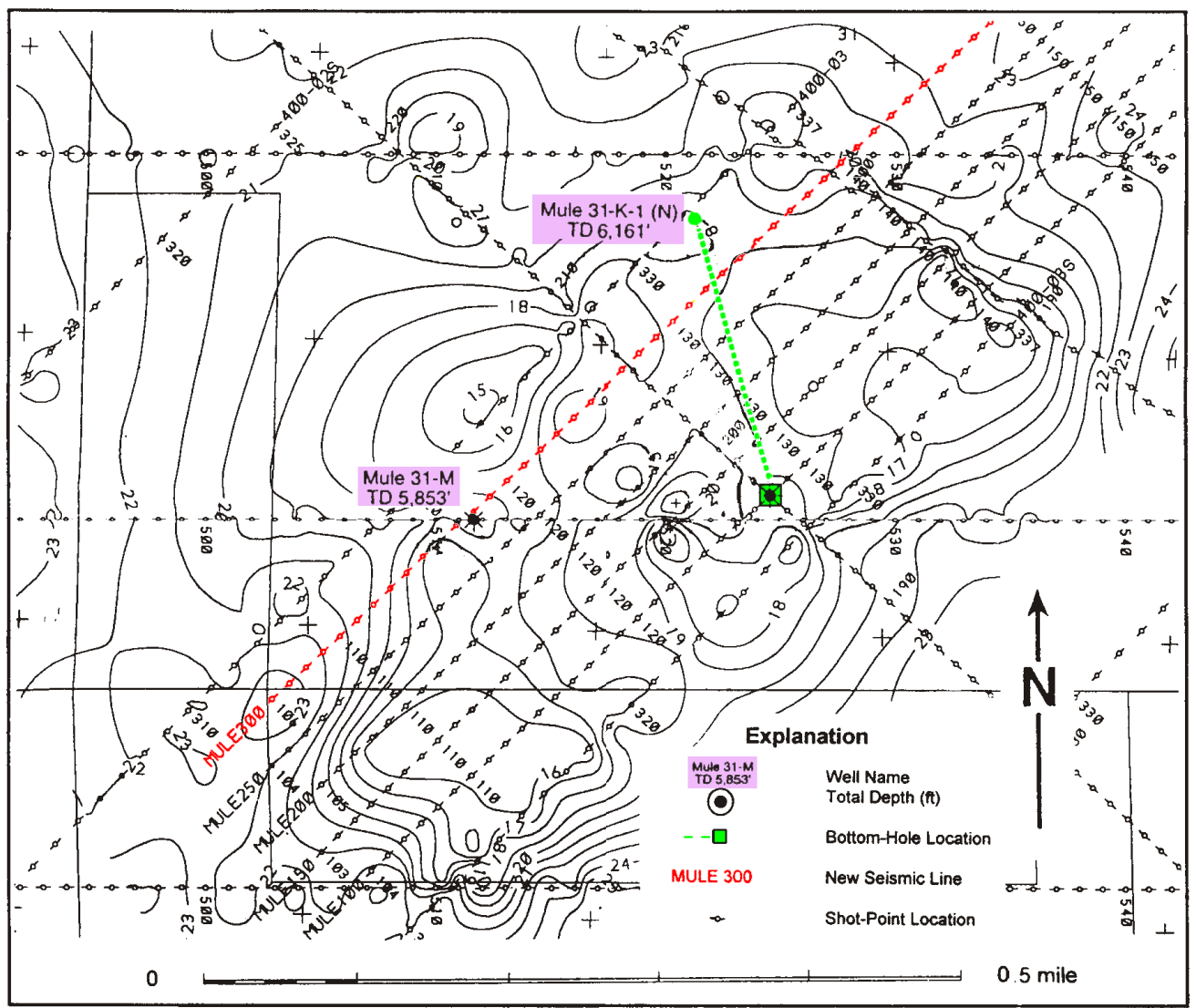

Figure 5-2. Ismay zone to Desert Creek zone (Pennsylvanian Paradox Formation) isochron map, Mule field area (see figure 5-1 for seismic line Mule 300). Contour interval $=1$ millisecond.

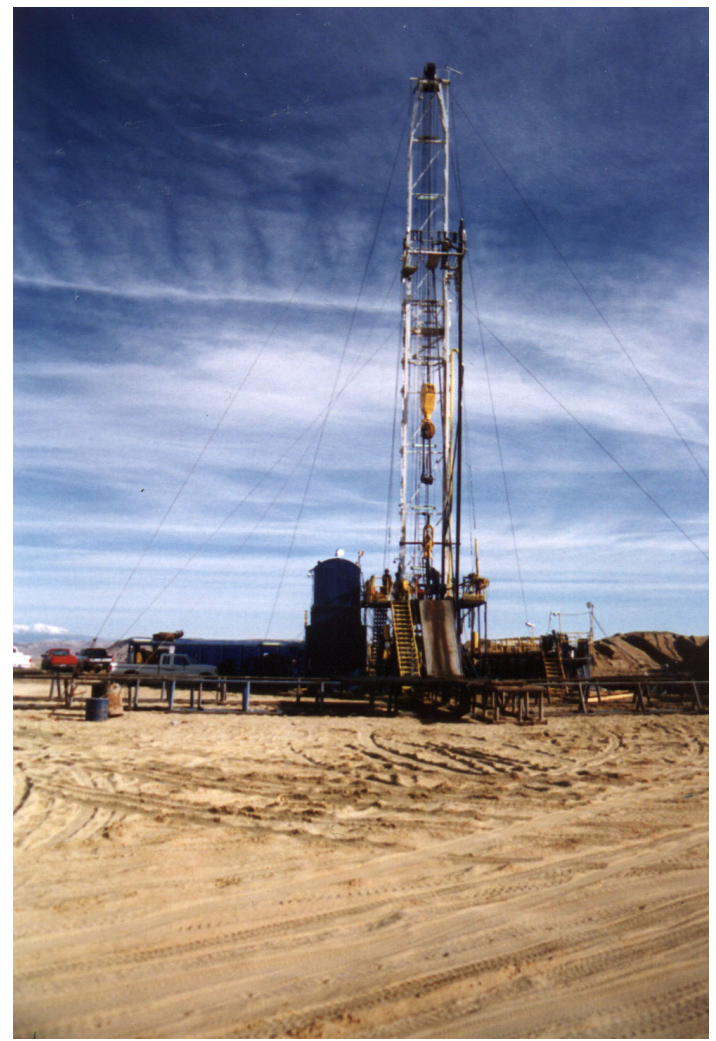

Figure 5-3. Drilling operations for the Mule 31-K-1 horizontal sidetrack well, Navajo Nation, San Juan County, Utah. Photo by R.L. Bon, UGS. 


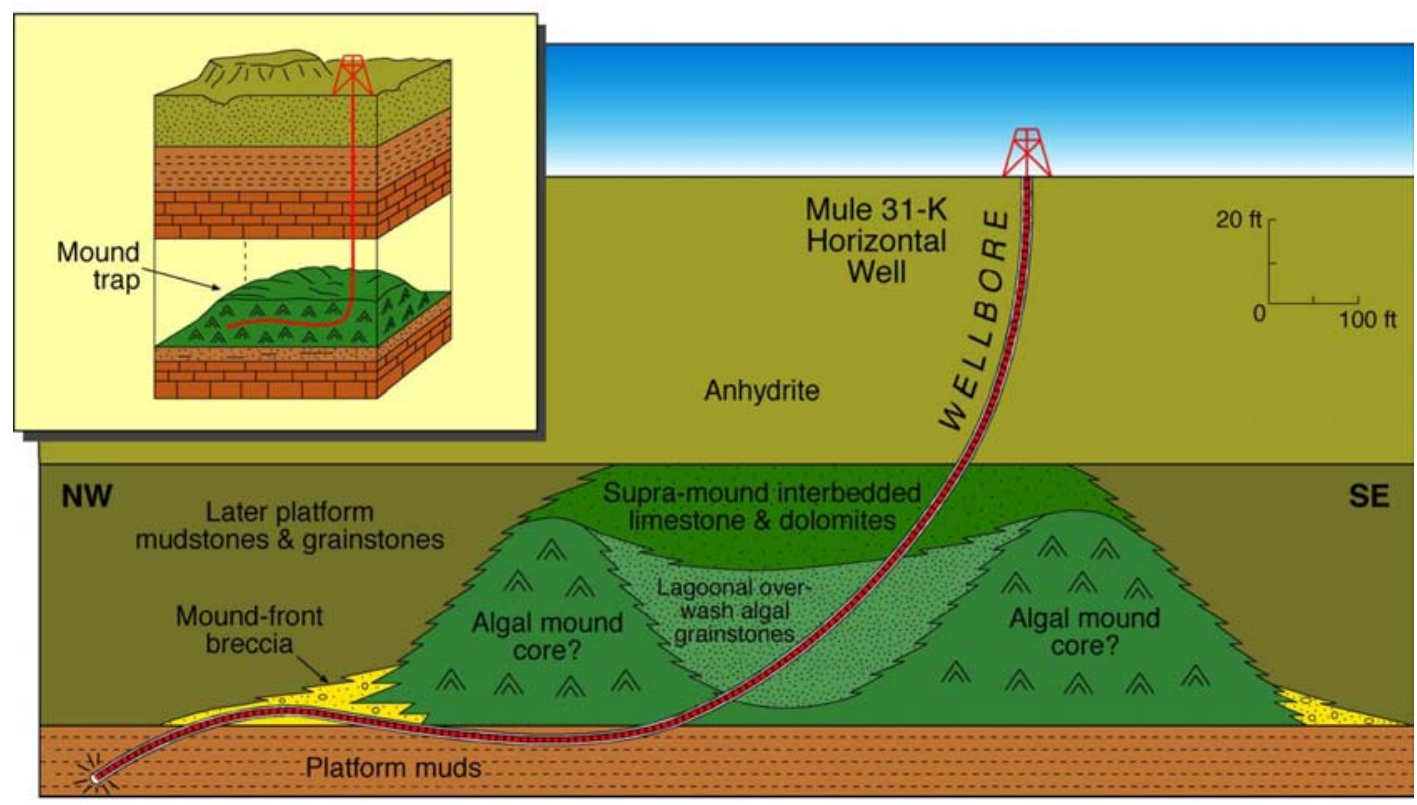

Figure 5-4. Schematic diagram of the facies encountered by the Mule 31-K-1 horizontal sidetrack well.

(2) The horizontal sidetrack encountered a supra-mound interval 21 vertical feet (6.4 $\mathrm{m})$ thick consisting of very finely crystalline to micro-sucrosic dolomite and thin interbedded limestone. At a MD depth of 6,000 feet $(1,829 \mathrm{~m}), 38$ vertical feet $(11.6 \mathrm{~m})$ of algal grainstones were penetrated in what was expected to be the mound-core interval. These rocks may represent overwash deposits into a lagoon associated with the algal buildup. No algal bafflestones were encountered.

(3) At 6,065 feet $(1,849 \mathrm{~m}) \mathrm{MD}$, tight clay-rich packstone, marlstone, dolomite, and thin carbonaceous shale were encountered over a distance of 329 horizontal feet $(100 \mathrm{~m})$. These rocks possibly represent the platform interval, the base upon which algal colonies grew. At a measured depth of 6,171 feet $(1,881 \mathrm{~m})$, the wellbore was directed upward in an attempt to find the mound-core interval. At a MD of 6,395 feet $(1,949 \mathrm{~m})$ the lithology changed to a possible mound-front breccia consisting of packstone with algal and grainstone inclusions. The wellbore was turned downward at a MD of 6,670 feet $(2,033 \mathrm{~m})$ and, after penetrating 500 horizontal feet $(152 \mathrm{~m})$ of "mound-front facies," the wellbore returned to the possible platform interval packstones from a MD of 6,900 feet $(2,103 \mathrm{~m})$ to the end of the horizontal lateral. An alternate interpretation is that the wellbore only penetrated the supramound interval with the mound-core interval below remaining for an additional horizontal test.

The total depth and horizontal length were reached on March 26, 1997. Some zones of intercrystalline porosity in dolomites and black residual oil staining observed in the cuttings lead the operator to attempt a well completion. 


\section{Horizontal Completion}

The Mule No. 31-K-1 horizontal well was completed open hole following treatment with acid and several swab runs. The following intervals were treated with 15 percent HCL: (1) 6,900 to 6,960 feet (2,103-2,121 m) MD - 1,000 gallon (gal [3,785 L]) HCL, (2) 6,700 to 6,900 feet $(2,042-2,103 \mathrm{~m}) \mathrm{MD}-1,000 \mathrm{gal}(3,785 \mathrm{~L}) \mathrm{HCL}$, (3) 6,550 to 6,700 feet $(1,996-2,042 \mathrm{~m})$ MD - 2,000 gal (7,570 L) HCL, (4) 6,430 to 6,550 feet (1,960-1,996 m) MD - 3,000 gal (11,355 L) HCL, (5) 6,100 to 6,430 feet (1,859-1,960 m) MD - 1,000 gal (3,785 L) HCL, and (6) 5,980 to 6,100 feet (1,823-1,859 m) MD - 2,000 gal (7,570 L) HCL. After swabbing for five days, all load water had been recovered with oil recoveries ranging between 4 and 16 percent. Swabbing continued for six more days recovering about $300 \mathrm{bbls}\left(48 \mathrm{~m}^{3}\right)$ of fluid, containing 10 percent oil.

The well was shut in for two months after which the operator decided to conduct swabbing operations again. The result was much different with recoveries between 40 and 60 percent oil during four days of swabbing. The large amounts of water recovered from the first series of swab runs was apparently water lost during drilling operations. The Mule No. 31-K horizontal well finalized at a rate of 149 bbls $\left(24 \mathrm{~m}^{3}\right)$ of oil and 223 bbls $\left(35 \mathrm{~m}^{3}\right)$ of water per day respectively. The first year of production for the well is summarized in figure 5-5. As of January 1, 2002, the well has produced 21,502 BO $\left(3,419 \mathrm{~m}^{3}\right), 34$ MMCFG $\left(0.96\right.$ million $\left.^{3}\right)$, and 9,121 bbls of water (1,450 $\mathrm{m}^{3}$ ) (Utah Division of Oil, Gas and Mining, 2002).

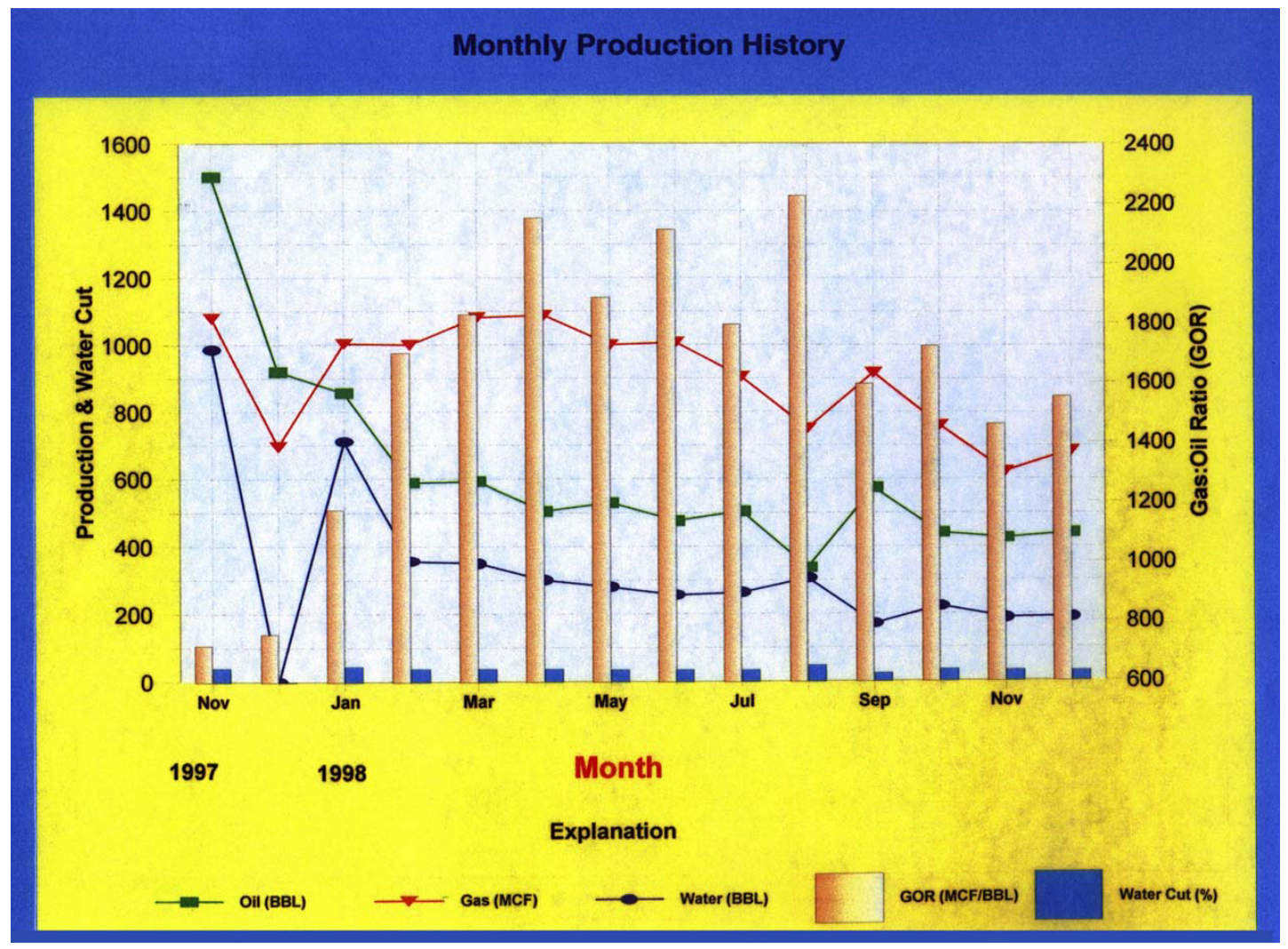

Figure 5-5. First year of production graph for the Mule 31-K-1 horizontal sidetrack well. Production data from Kris Hartmann, Harken Southwest Corporation (written communication, 1998). 


\title{
CHAPTER VI \\ RESERVOIR MODELING OF THE DESERT CREEK ZONE
}

\author{
Douglas M. Lorenz \\ REGA Inc.
}

\begin{abstract}
Anasazi Field
Of the five carbonate buildup fields in the Desert Creek zone originally identified as candidates for detailed study, the Anasazi field was selected for the initial geostatistical modeling and reservoir simulation (figure 1-1). This mound complex had the longest production history (more than seven years) and largest amount of hard data for reservoir characterization (four logged wells, three of which are also cored through the Desert Creek zone), has the most seismic coverage (six, two-dimensional lines), and was considered the most promising candidate for enhanced recovery.

The key to increasing ultimate recovery from the Anasazi field (and similar fields in the basin), is to design either waterflood or $\mathrm{CO}_{2}$-miscible flood projects capable of forcing oil from high-storage-capacity but low-recovery supra-mound units into the high-recovery mound-core units. The results of these statistical models were being used in reservoir simulations to test and design those types of projects.
\end{abstract}

\section{Geometry and General Stratigraphy}

A detailed carbonate isolith map of the Desert Creek zone in the Anasazi area (figure 61) shows two mound buildups of more than 60 feet $(18 \mathrm{~m})$ thick, based on well log and seismic information. Three peripheral dry holes (Navajo No. 4-D [section 5, T. 42 S., R. 24 E., SLBL], Navajo No. D-1 [section 6, T. 42 S., R. 24 E., SLBL], and Navajo No. B-7 [section 32, T. 41 S., R. 24 E., SLBL]) do not penetrate any mound buildup facies in the Desert Creek zone, and serve to define the average non-mound Desert Creek thickness (110 feet [34 m]) in the vicinity of the Anasazi field.

A variety of carbonate facies is encountered in all four Anasazi wells which causes a high degree of spatial heterogeneity in reservoir properties. To adequately represent the effects of this heterogeneity on reservoir behavior, detailed characterizations of these heterogeneous facies and their joint distributions within the reservoir volume must be developed.

In the mound-buildup area, the Desert Creek zone is stratigraphically subdivided into three intervals. The lowest interval, averaging 25 feet $(8 \mathrm{~m})$ in thickness, consists largely of tight dolomudstones, with some slightly enhanced porosity (up to 10 percent) and interbedded dolomitized packstones and wackestones. A middle interval or mound core (30 to 50 feet [9-15 $\mathrm{m}$ ] thick) is comprised almost entirely of phylloid-algal bafflestone. These mound-building limestones exhibit substantial porosity (up to 22 percent locally) and permeability (generally 150 to $300 \mathrm{md}$; locally greater than 1,000 md). Thin dolomudstones, packstones, wackestones, and a few grainstones are found in flanking peripheral areas. The upper interval (55 to 65 feet [17-20 m] thick) contains largely dolomitized mudstones, packstones, wackestones, and grainstones in which each lithotype shows a wide range of secondary pore system alteration from slight (porosity less than 2 percent and permeability less than $0.1 \mathrm{md}$ ) to significant (porosity greater than 24 percent and permeability up to $50 \mathrm{md}$ ). Based on detailed core and $\log$ 


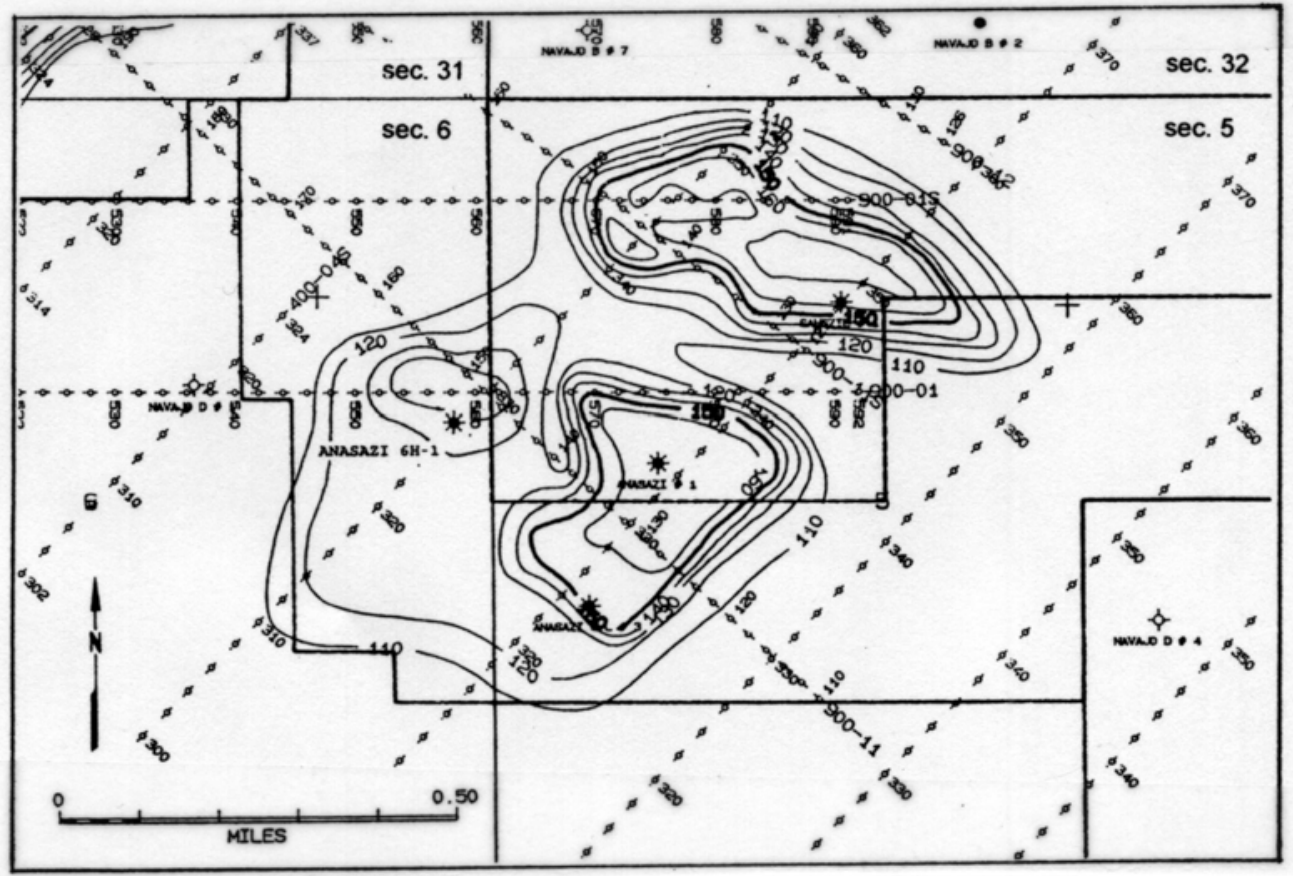

Figure 6-1. Gross Desert Creek isopach based on geophysical well log and seismic data, Anasazi field, sections 5 and $6, T$. 42 S., R. 24 E., Salt Lake Base Line, San Juan County, Utah. Contour interval $=$ 10 feet. Dotted lines are seismic shot points.

interpretations of the Anasazi wells, and on geological studies of nearby, analogous, Pennsylvanian, carbonate-mound buildups (see Chapter IV, Outcrop and Modern Reservoir Analogues), these three successive stratigraphic intervals are identified as distinct timeequivalent sequences, termed the "platform interval," the "mound-core interval," and the "supra-mound interval," respectively. Detailed correlation of flooding surfaces (figure 6-2) demonstrates their lateral continuity within the Anasazi mound complex. The mound-core and supra-mound intervals together constitute the Anasazi reservoir; the platform interval is tight and does not yield commercial hydrocarbons.

\section{Reservoir Architecture}

To represent the vertical and lateral heterogeneity known to be present in the Anasazi reservoir, yet ensure that the well-documented lateral and vertical communication also is realistically modeled, a detailed facies interpretation of the conventional core from three Anasazi wells (Anasazi Nos. 1, 5L-3, and 6H-1) was undertaken. From these results, together with the log interpretations (figure 6-3), conventional core analysis, and geologically inferred lateral facies relationships based on the outcrop studies, a reservoir modeling procedure was designed to incorporate the major facies types as individual architectural entities, each exhibiting internal heterogeneities in reservoir properties but contrasting sharply between the individual lithotypes. Ten architecturally distinct lithotypes were identified in the mound-core interval, eight of which also comprise the supra-mound interval in the Anasazi reservoir (table 6-1). They include the tight mudstones, packstones, wackestones, and grainstones characteristic of the off-mound areas in both intervals (figure 6-4); similar facies exhibiting enhanced porosity resulting from dolomitization and/or leaching found in the buildup areas of the supra-mound interval (and also scattered throughout off-mound areas, figures 6-5 and 6-6); and the porous, highly permeable phylloid-algal bafflestones and associated mound-flank breccias (figure 6-7) which are almost entirely restricted to the buildup areas of the mound-core interval. 


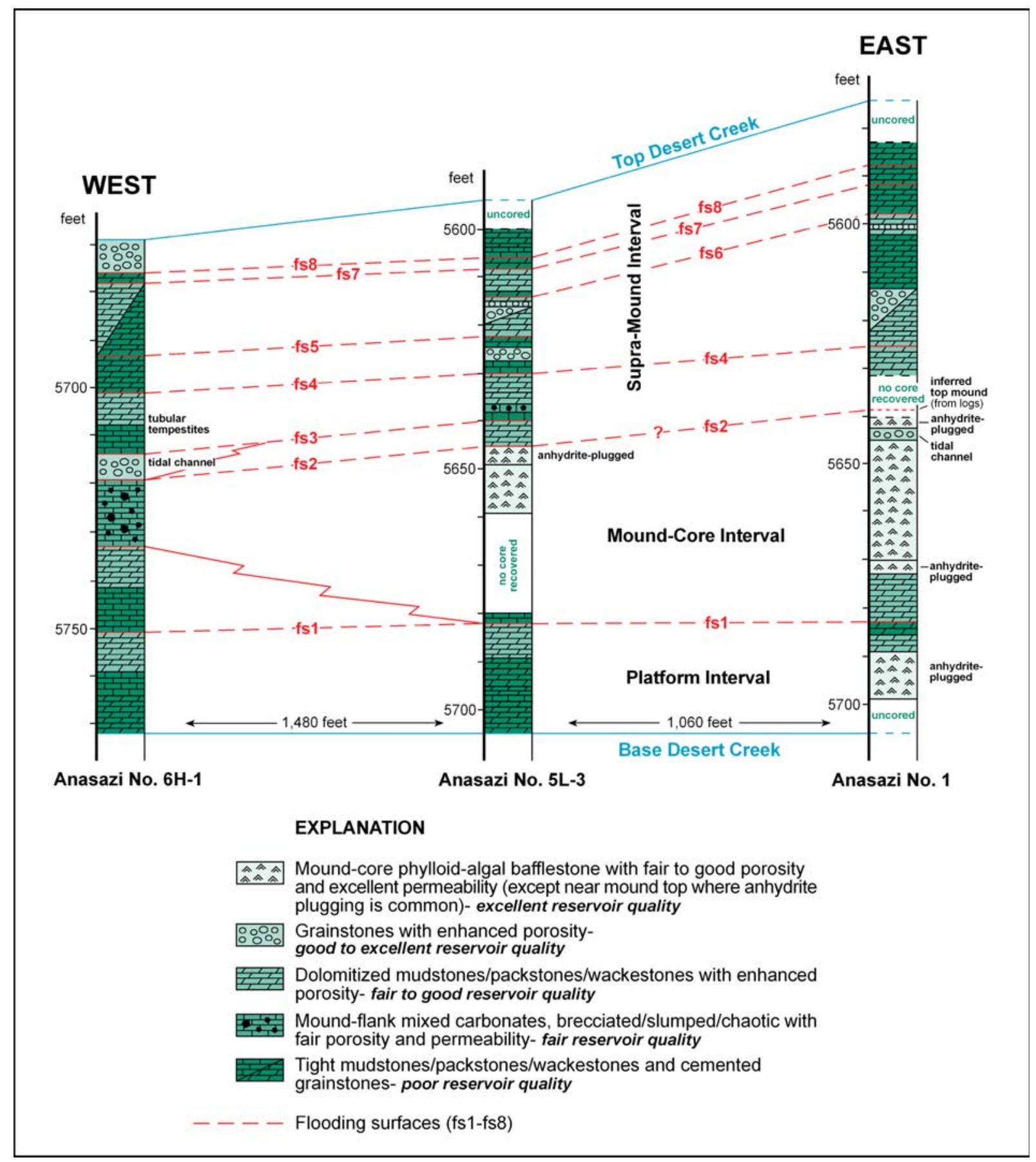

Figure 6-2. Stratigraphic cross section across Anasazi field displaying reservoir lithotypes, flooding surfaces, and facies relations within the Desert Creek platform, mound-core, and supra-mound intervals based on core. 


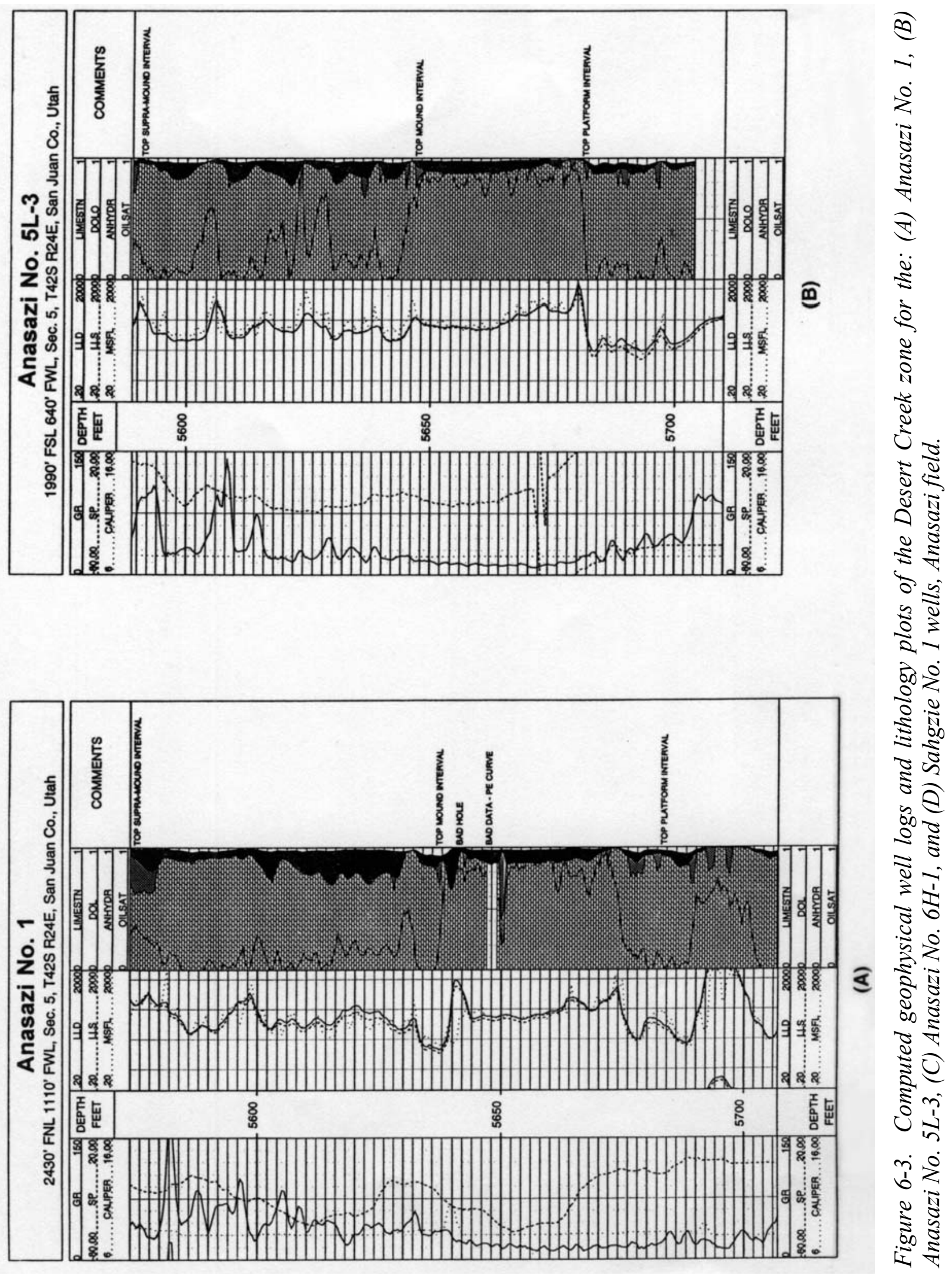



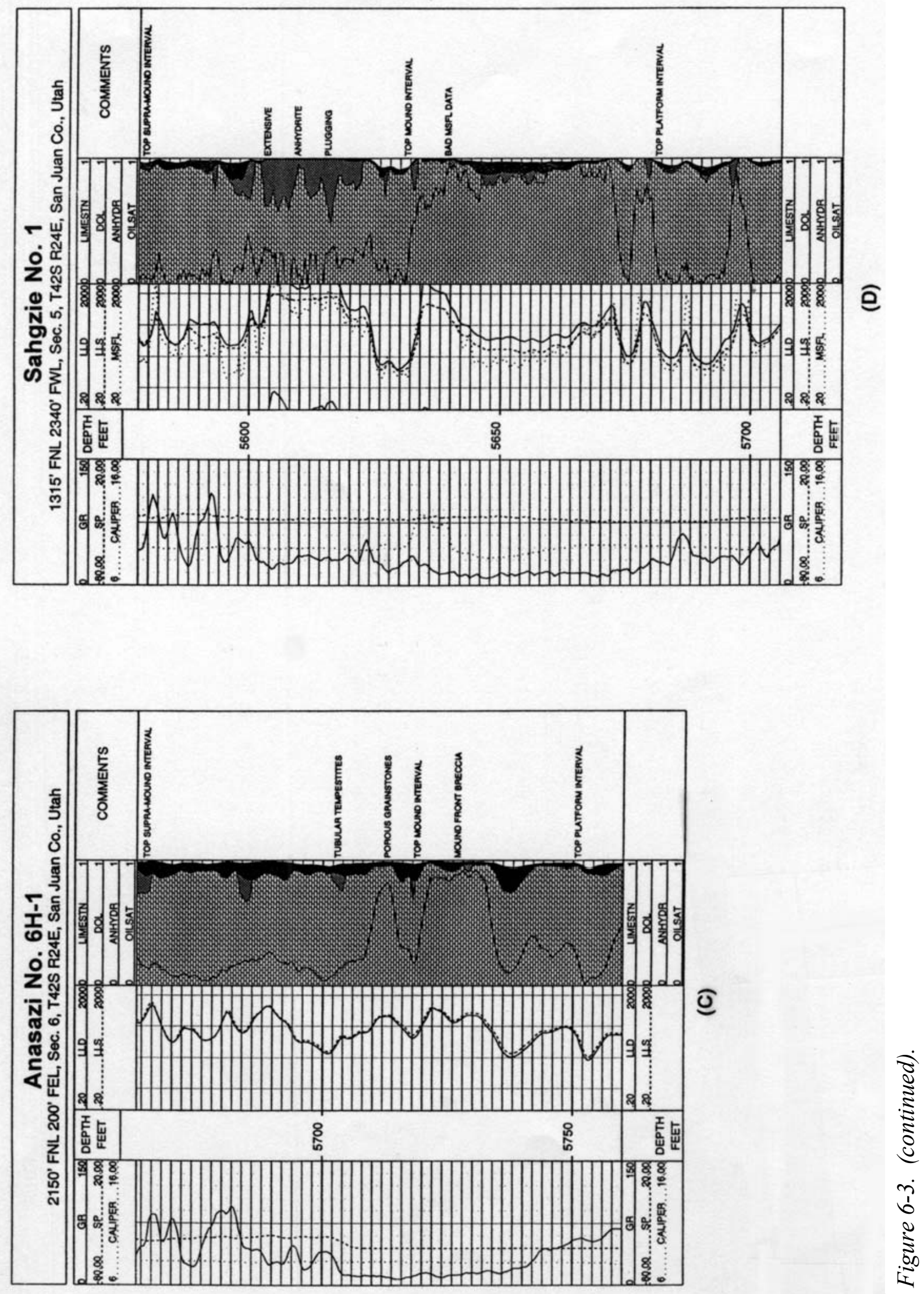


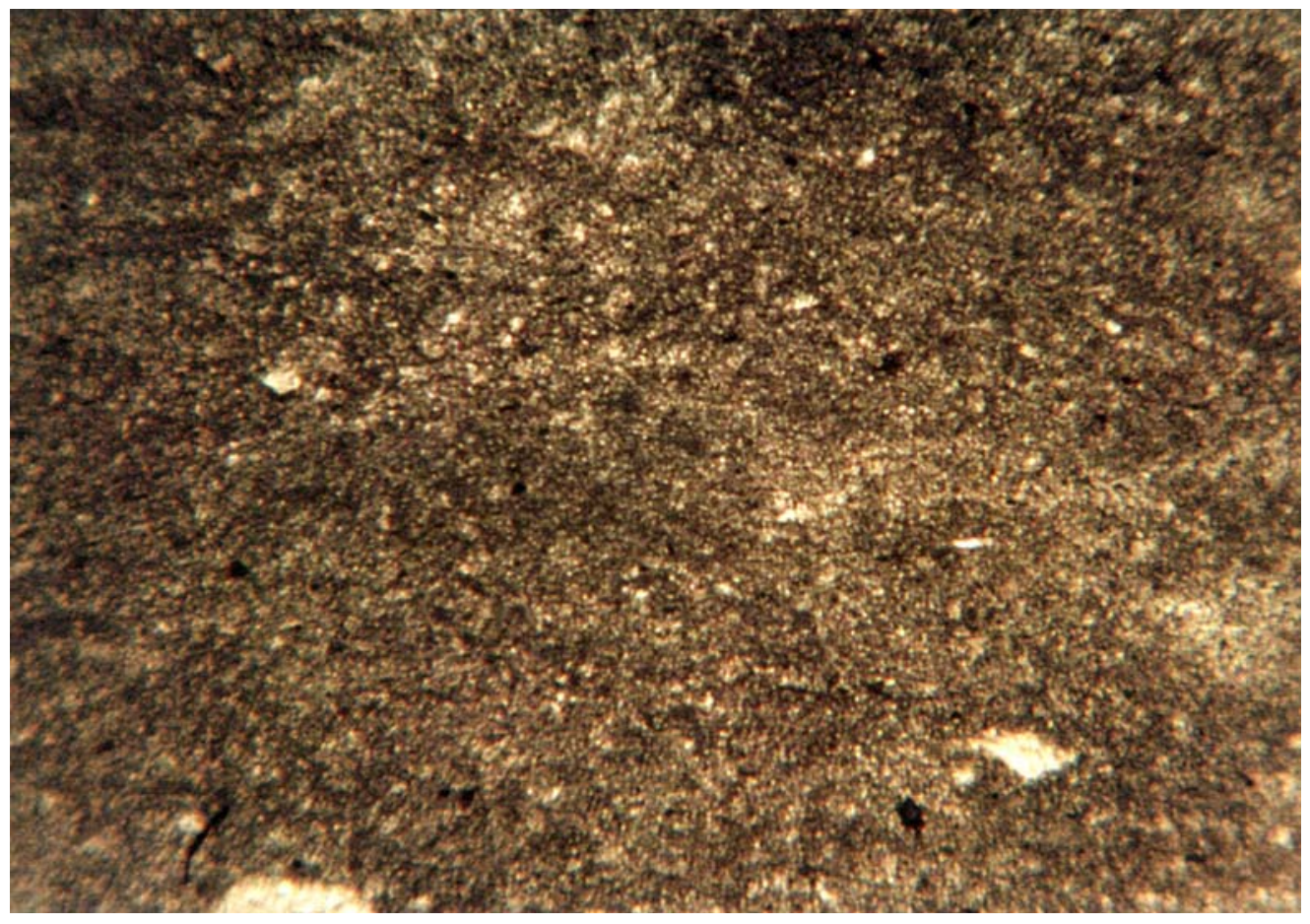

A

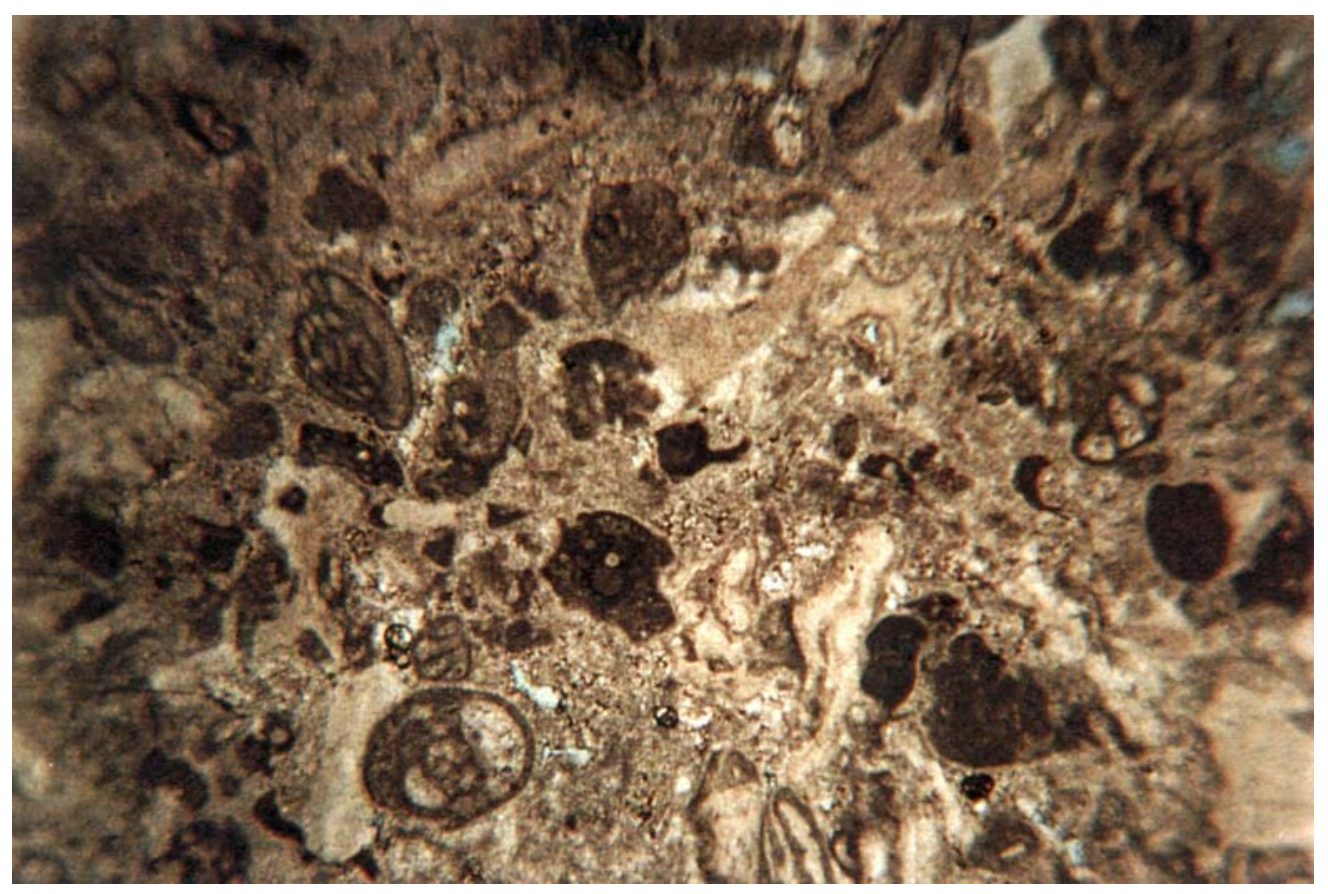

B

Figure 6-4. Photomicrographs of thin sections (plane light view) showing low-quality architectural lithotypes (24x). (A) Low-permeability mudstone from the Anasazi No. 1 well (sample depth = 5,622.6 feet [1,713.7 m]). White objects are recrystallized calcite. (B) Low-permeability grainstone from the Anasazi No. $5 \mathrm{~L}-3$ well (sample depth $=5,629.6$ feet $[1,715.8 \mathrm{~m}]$ ). White areas are pore-filling calcite cement; dark objects are bioclastic fragments. 


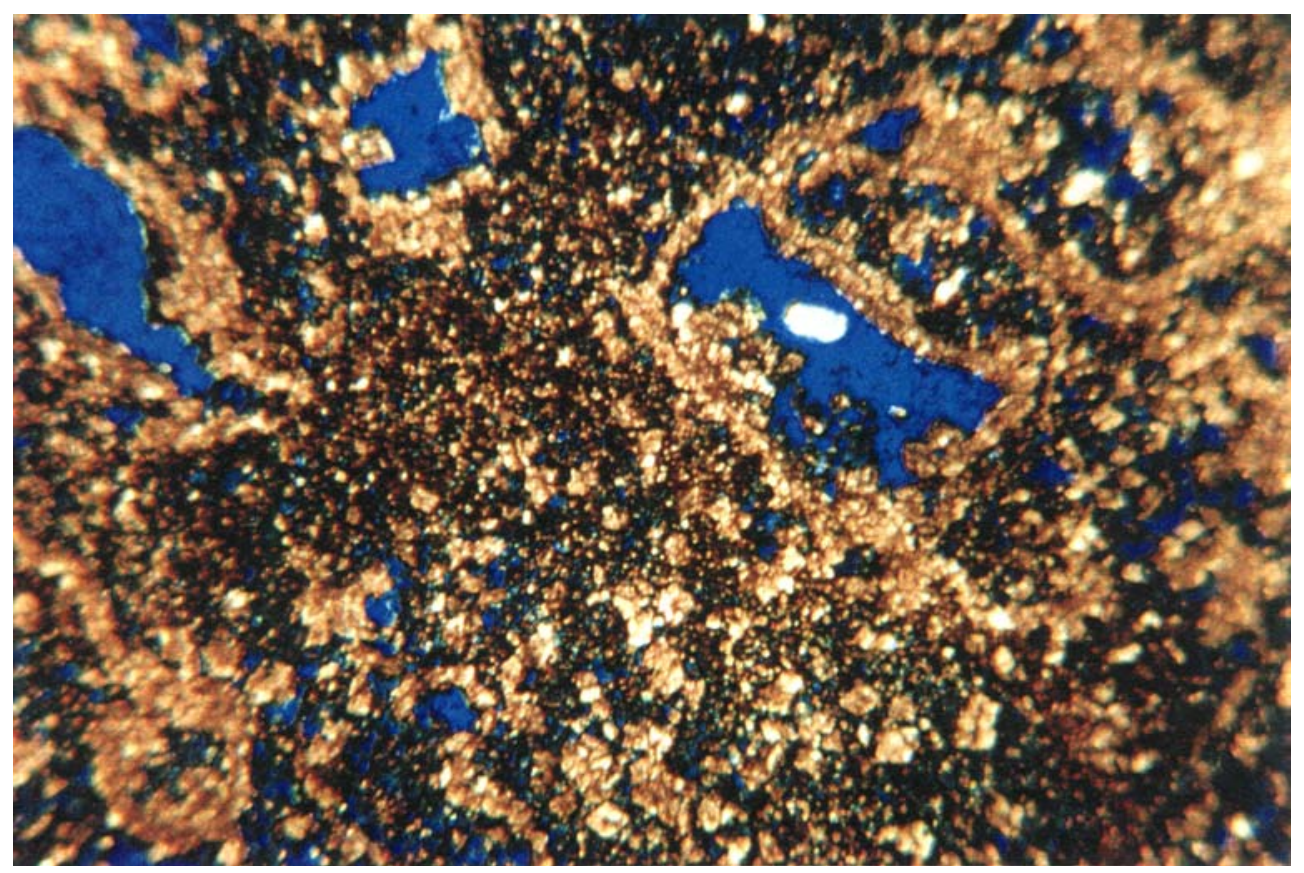

A

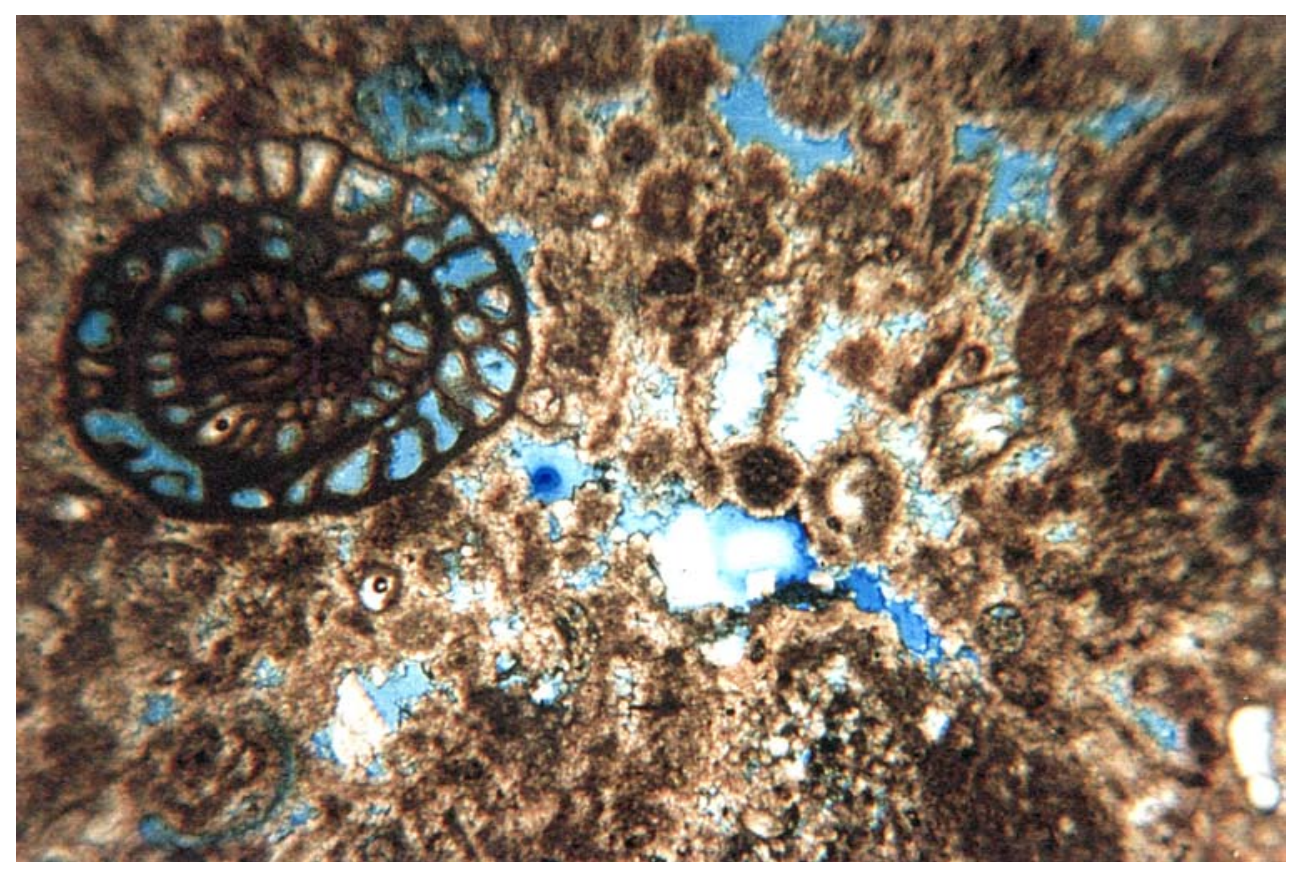

B

Figure 6-5. Photomicrographs of thin sections (plane light view) showing high-quality architectural lithotypes (24x). (A) Dolomitized mudstone, with enhanced porosity, from the Anasazi No. 6H-1 well (sample depth = 5,691.2 feet $[1,734.6 \mathrm{~m}])$. Blue objects are enhanced pores, recrystallized dolomite is white, and interstitial bitumen is black. (B) Grainstone, with enhanced porosity, from the Anasazi No. 5L-3 well (sample depth = 5,616.2 feet $[1,711.7 \mathrm{~m}])$. Pores are uniformly white to light blue; many are lined with cement; dark objects are bioclastic fragments. 


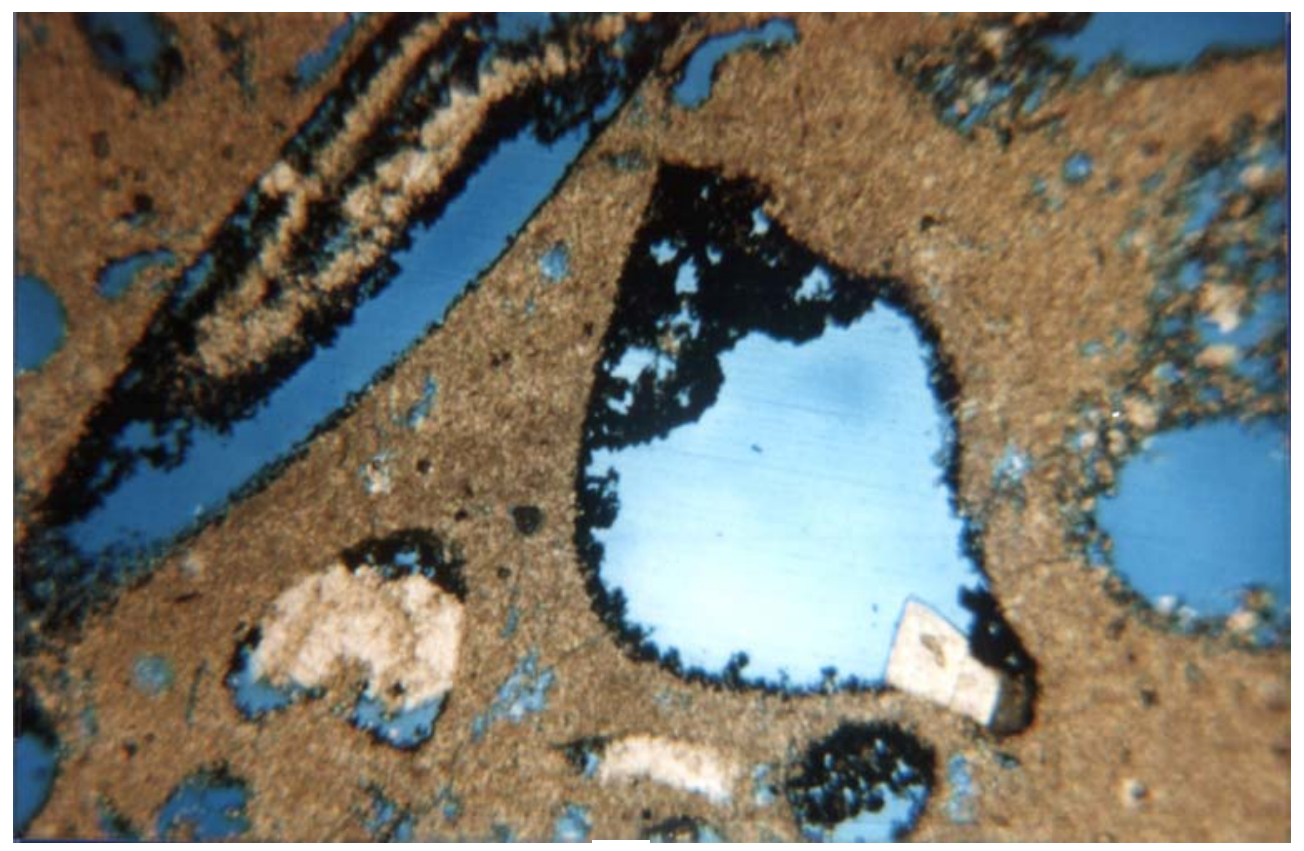

A

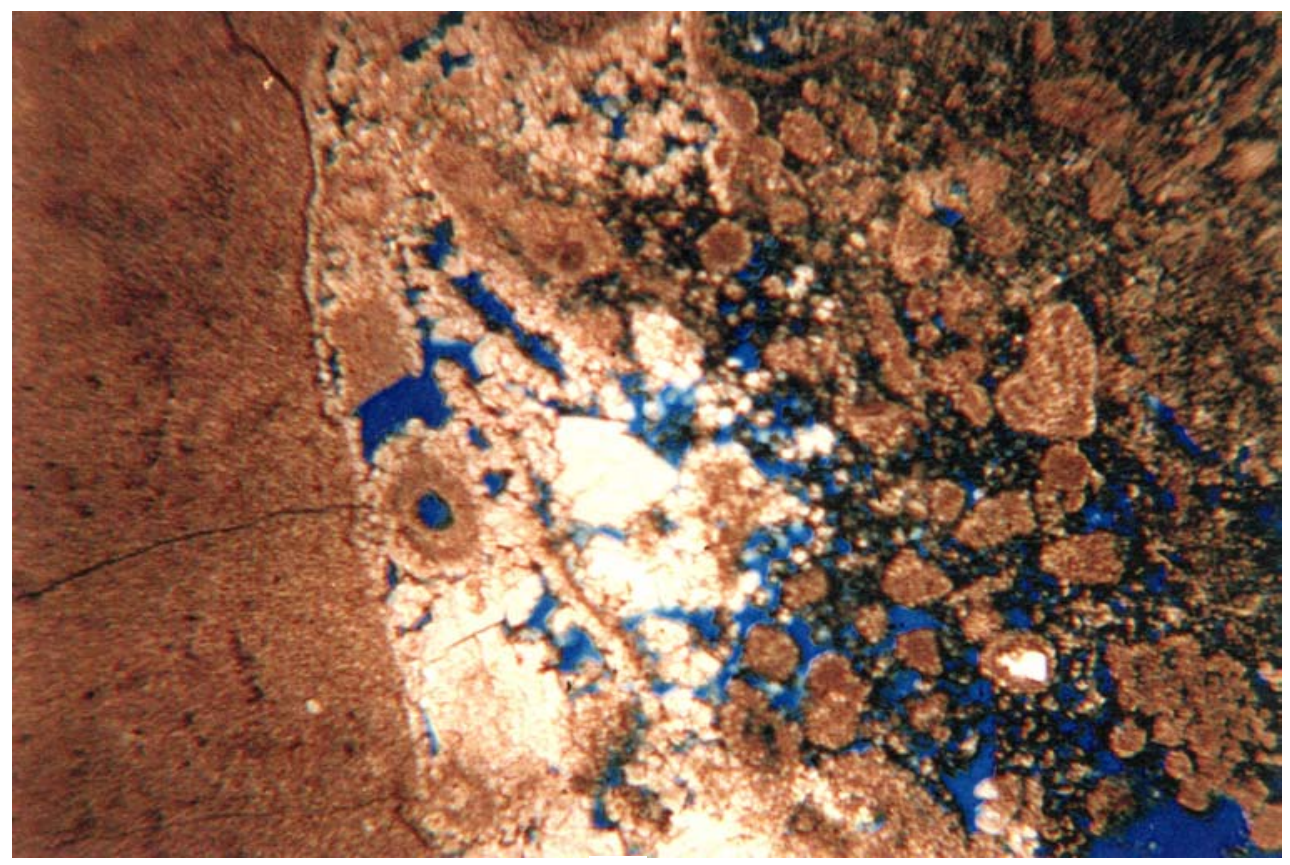

B

Figure 6-6. Photomicrographs of thin sections (plane light view) showing moderate- to high-quality architectural lithotypes. (A) Dolomitized packstone, with enhanced porosity, from the Anasazi No. 1 well (sample depth $=5,621$ feet $[1,713 \mathrm{~m}])(24 x)$. Large, uniform white and blue objects are enhanced pores; pinpoint white and gray areas are microcrystalline dolomite, and black areas are residual bitumen. (B) Tubular tempestite (relict burrow) from the Anasazi No. 6H-1 well (sample depth $=5,706$ feet $[1,739 \mathrm{~m}])(47.5 x)$. The burrow contains small and mid-size pores (white objects) surrounded by undisturbed, tight dolomitized mudstone. 


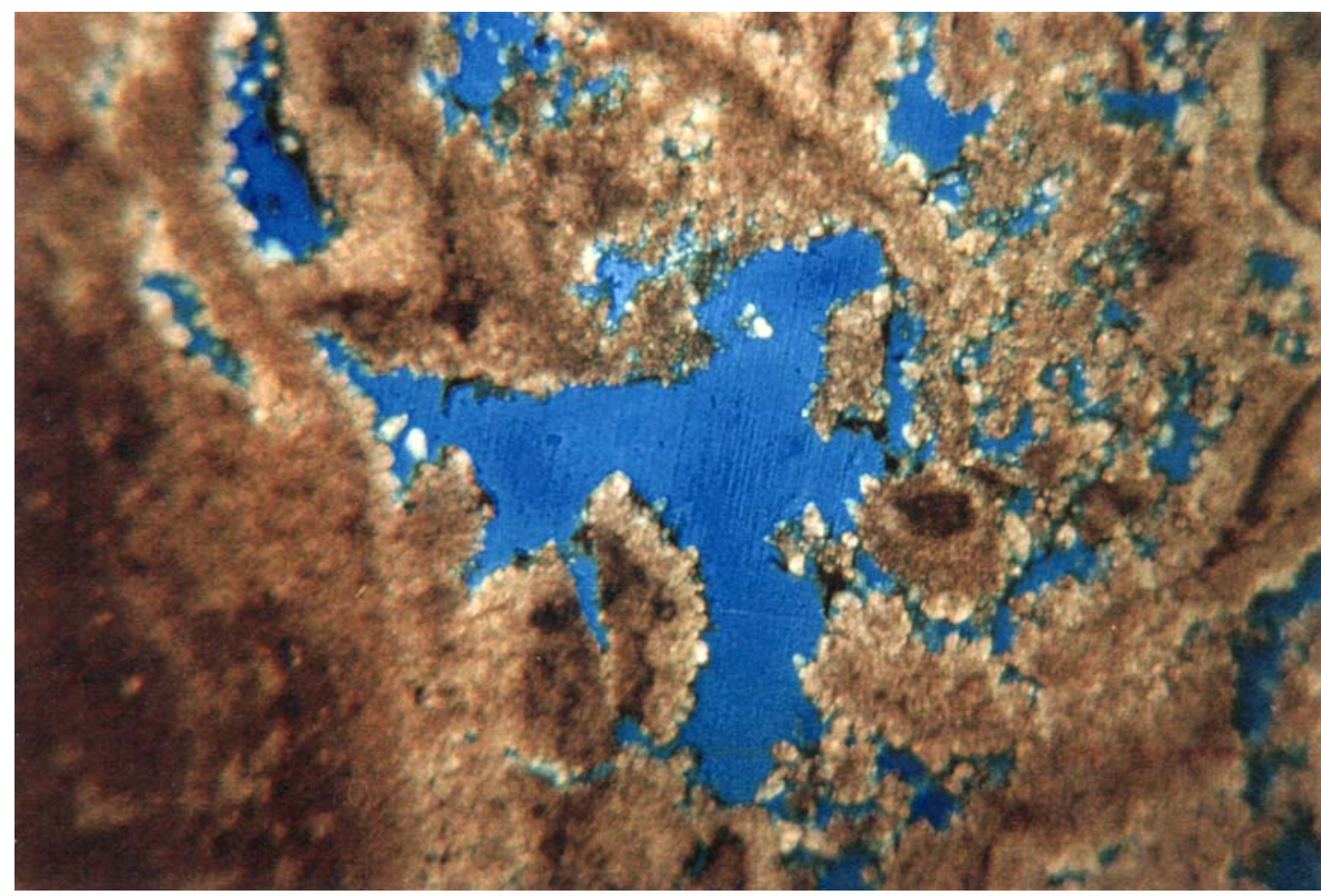

Figure 6-7. Photomicrograph of a thin section (plane light view) showing a phylloidalgal bafflestone from the Anasazi No. 1 well (sample depth = 5,654.3 feet [1,723.3 m]) (24x). Large, irregularly shaped, cement-lined pores (uniformly blue) are bounded by phylloid-algal plates (dark elongate objects).

Table 6-1. Average reservoir properties of architectural lithotypes, Anasazi field.

\begin{tabular}{|l|l|l|c|l|}
\hline \multicolumn{1}{|c|}{ Lithotype } & $\begin{array}{c}\text { Average Bed } \\
\text { Thickness } \\
\text { (ft) }\end{array}$ & $\begin{array}{c}\text { Average } \\
\text { Porosity } \\
(\%)\end{array}$ & $\begin{array}{c}\text { Average } \\
\text { Permeability (md) }\end{array}$ & $\begin{array}{c}\text { Volume } \\
\text { Proportion }\end{array}$ \\
\hline Tight Mudstone & 3.7 & 2 & 0.25 & 0.24 \\
\hline Dolomitized Mudstone & 5.5 & 9 & 1.51 & 0.06 \\
\hline Porous Mudstone & 2.9 & 11 & 2.00 & 0.05 \\
\hline Tight Packstone/Wackestone & 2.4 & 2 & 0.02 & 0.14 \\
\hline Porous Packstone/Wackestone & 3.8 & 10 & 1.80 & 0.05 \\
\hline Tight Grainstone & 2.2 & 2 & 0.15 & 0.07 \\
\hline Porous Grainstone & 3.2 & 15 & 15.00 & 0.08 \\
\hline $\begin{array}{l}\text { Tubular Tempestites in Mudstone/ } \\
\text { Wackestone/Packstone }\end{array}$ & 6.7 & 9 & 8.00 (est) & 0.07 \\
\hline Phylloid Algal Bafflestone & 42.0 & 10 & 150.00 & 0.22 \\
\hline Mound-Flank Breccia & 13.0 & 8 & 30.00 (est) & 0.02 \\
\hline
\end{tabular}




\section{Reservoir Model Geometry}

The overall Desert Creek zone in the Anasazi field is represented by the isopach in figure 6-1, that includes not only the reservoir interval, but also the underlying non-reservoir platform interval and a sequence of overlying anhydrites. However, the aggregate nonreservoir thickness in all four Anasazi wells is remarkably constant, measuring within two feet $(0.6 \mathrm{~m})$ of the average thickness of 62 feet $(19 \mathrm{~m})$. Consequently, an isolith map of the reservoir (mound-core plus supra-mound) intervals can be obtained (figure 6-8) by subtracting 62 feet $(19 \mathrm{~m})$ from the Desert Creek isopach. This isolith map is used in the model to define the upper boundary of the Anasazi reservoir. The base of the reservoir (= top of the platform interval) is approximately co-planar in the four Anasazi wells, and is represented in the model as a surface of uniform slope, dipping at $0.7^{\circ}$ to the southeast. Figure 6-8 also shows the $x-y$ map grid defined in the model, which consists of a 30 X 50 grid block array, with individual block dimensions of 105 feet $(32 \mathrm{~m})$ square.

Based on the observed bedding frequencies, an average layer thickness of two feet $(0.6$ $m)$ in the mound buildup areas was selected for the initial reservoir model. Although the total reservoir thickness varies considerably (figure 6-8), the relative proportions of mound-core and supra-mound interval thicknesses in the four Anasazi wells are all about 0.4 and 0.6, respectively (figure 6-3). Thus, the mound-core and supra-mound intervals are subdivided into 20 and 30 equal-thickness layers, which yield approximately 2-foot $(0.6-\mathrm{m})$ layers within and over the mound buildups, thinning to about half that in the peripheral areas. Consequently, the initial Anasazi model consists of 50 layers, each divided geographically into 1,500 x-y blocks, for a total of 75,000 grid blocks, representing an overall volume of 57.8 million cubic feet (17.6 million $\mathrm{m}^{3}$ ).

\section{Seismic Constraints}

One of the most difficult problems normally encountered in reservoir characterization is the lack of adequate data on patterns of lateral variation in reservoir properties between wells. Lacking hard data from horizontal wells or detailed three-dimensional seismic records, the only recourse is to constrain the model using "soft" information from other sources. Fortunately, data from the six two-dimensional seismic lines over the Anasazi field (figure 6-1) are good quality and can be used to roughly characterize (constrain) lateral variations in average reservoir quality.

Based on two interpreted indices of reservoir quality from the common-depth-point stacked and migrated seismic cross sections, a single index (designated the "Reservoir Quality Index," or RQI), scaled from 0 to 10, was derived and mapped (figure 6-9). This map clearly shows that the best reservoir quality roughly coincides with areas of greatest mound buildup (figure 6-8). However, translation of RQI into equivalent quantitative expressions of standard reservoir properties is somewhat ambiguous. Acoustic properties of rocks are affected by such static reservoir properties as lithology, porosity, and thickness, but not (directly) by flow properties like permeability. Hence, since the original seismic interpretations were designed to complement the isochrons on which the reservoir thicknesses are based (figure 6-8), the RQI is likely to be primarily a function of porosity and lithology. 


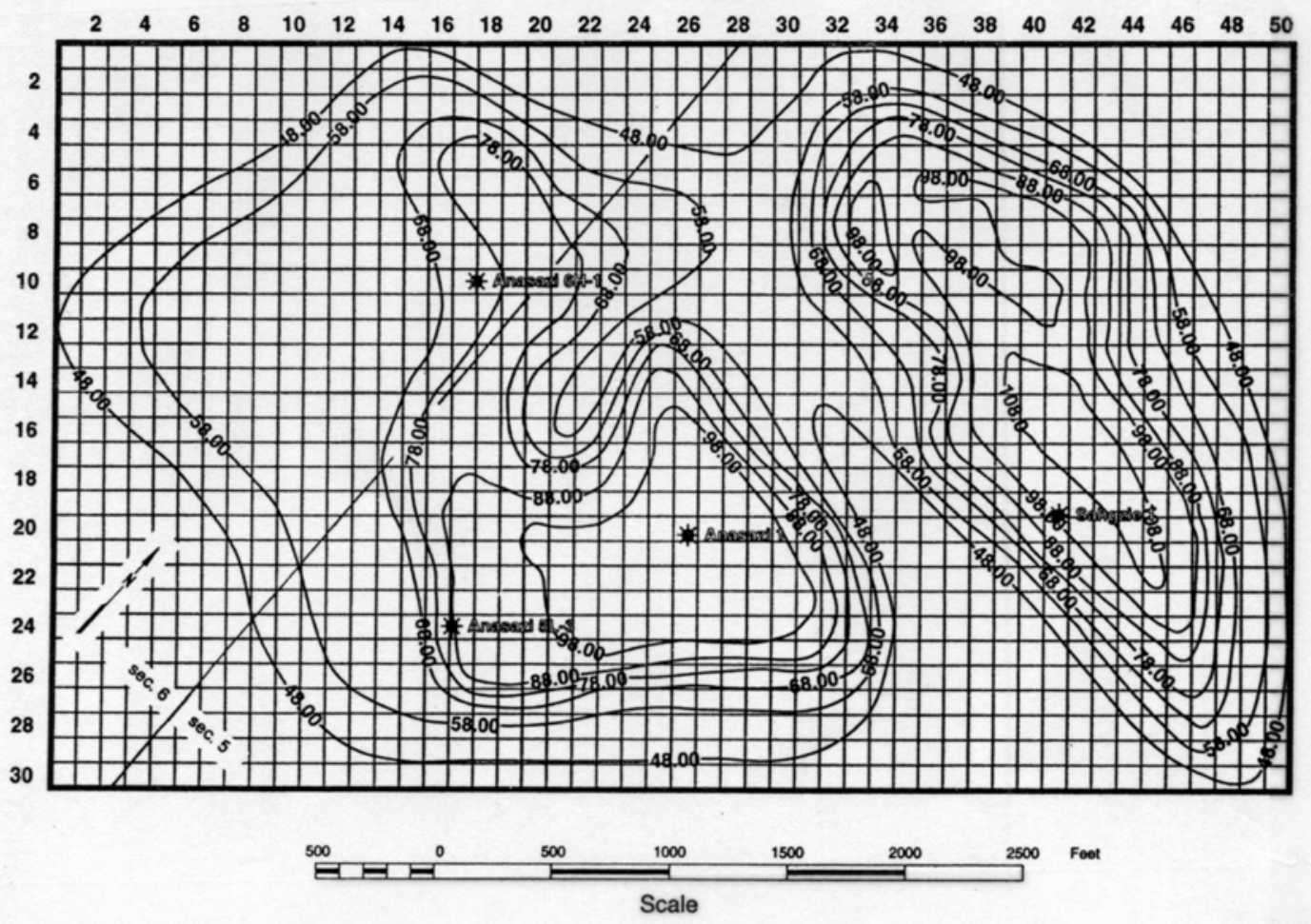

Figure 6-8. Anasazi reservoir gridded isolith map; contour interval $=10$ feet, grid block $=105$ square feet. Note that the geographic orientation of the map is rotated counterclockwise by $40^{\circ}$ relative to figure 6-1.

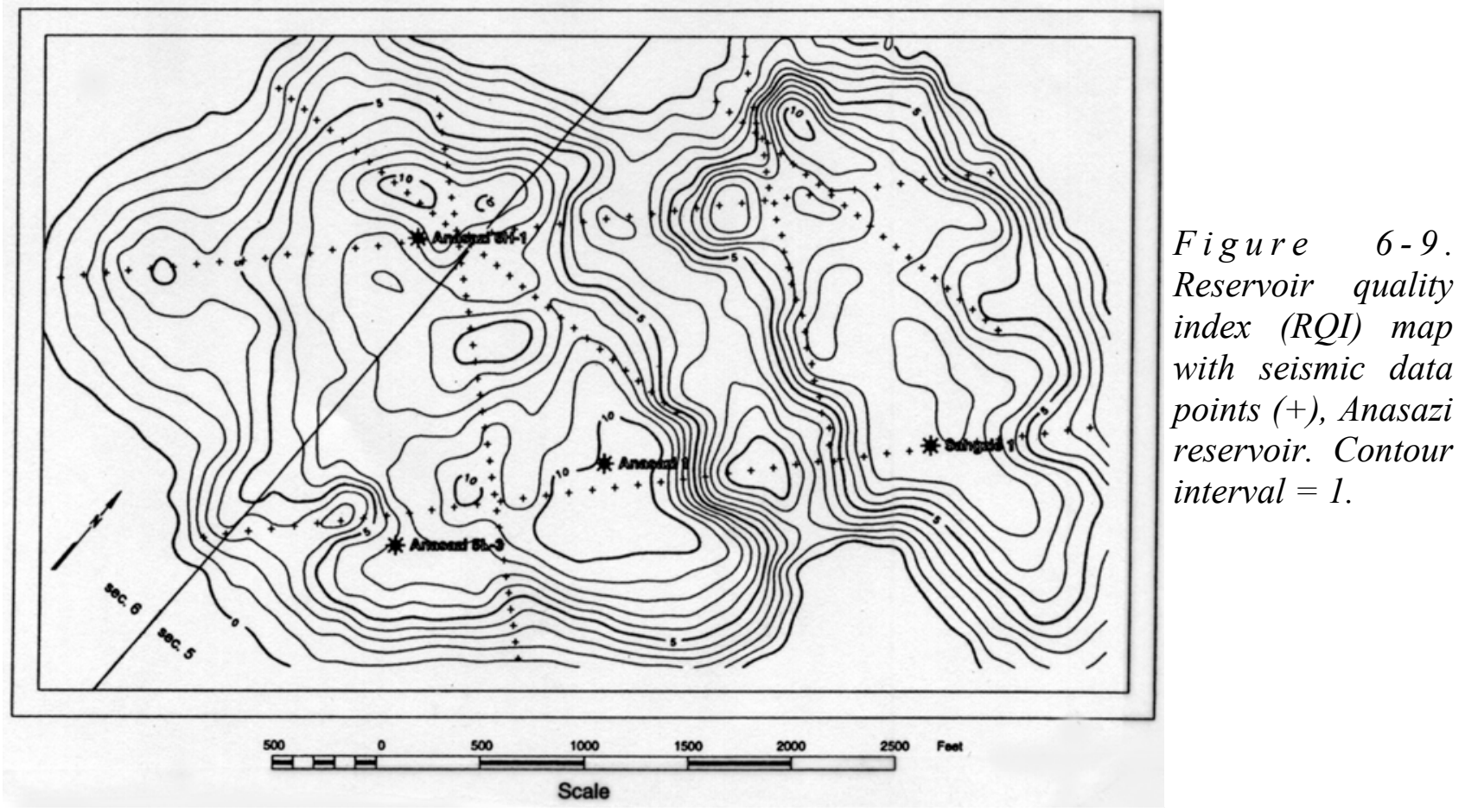


A plot of the RQI and average porosity derived from well logs in the four Anasazi wells (figure 6-10) shows that both lithology and porosity affect RQI. The anomalously low porosity relative to the high RQI in the Sahgzie No. 1 well is chiefly attributable to massive anhydrite plugging in the supra-mound dolomites (figure 6-3D). Because the distribution of anhydrite in the reservoir is unknown, the RQI-to-average porosity transfer function is defined as a separate linear function at each well (figure 6-10), thus fitting the hard data exactly. The common zerointercept at an average porosity of 4 percent corresponds to the average porosity over all nonpay intervals among the four wells. At grid points between the wells, the slope coefficient is defined as an inverse-distance weighted average of the slopes at the four wells (figure 6-10). The resulting map of average reservoir porosity (figure 6-11) will be used as a constraining variable for lateral variation in the reservoir modeling.

\section{Reservoir Model Design}

Although significant vertical and lateral variations in reservoir properties characterize the Anasazi reservoir, these variations can be partially resolved by representing the different lithotypes as distinct architectural components, within each of which the pattern of spatial variation distinctive of that lithotype can be treated individually. The overall modeling strategy was to first emplace the various lithotypes as separate "bodies" or "architectural objects" (a

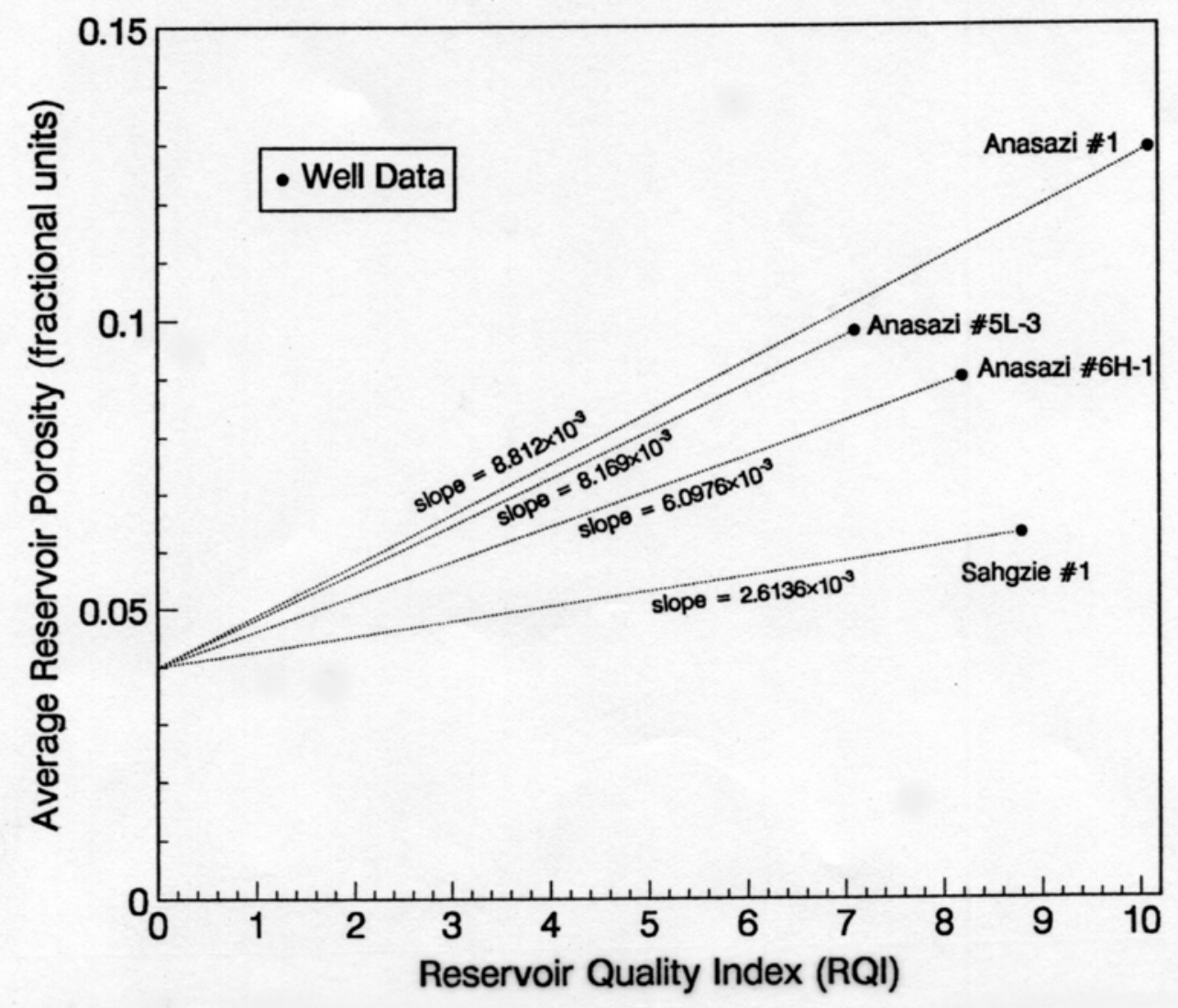

Figure 6-10. Estimation of average porosity from RQI, Anasazi reservoir. 


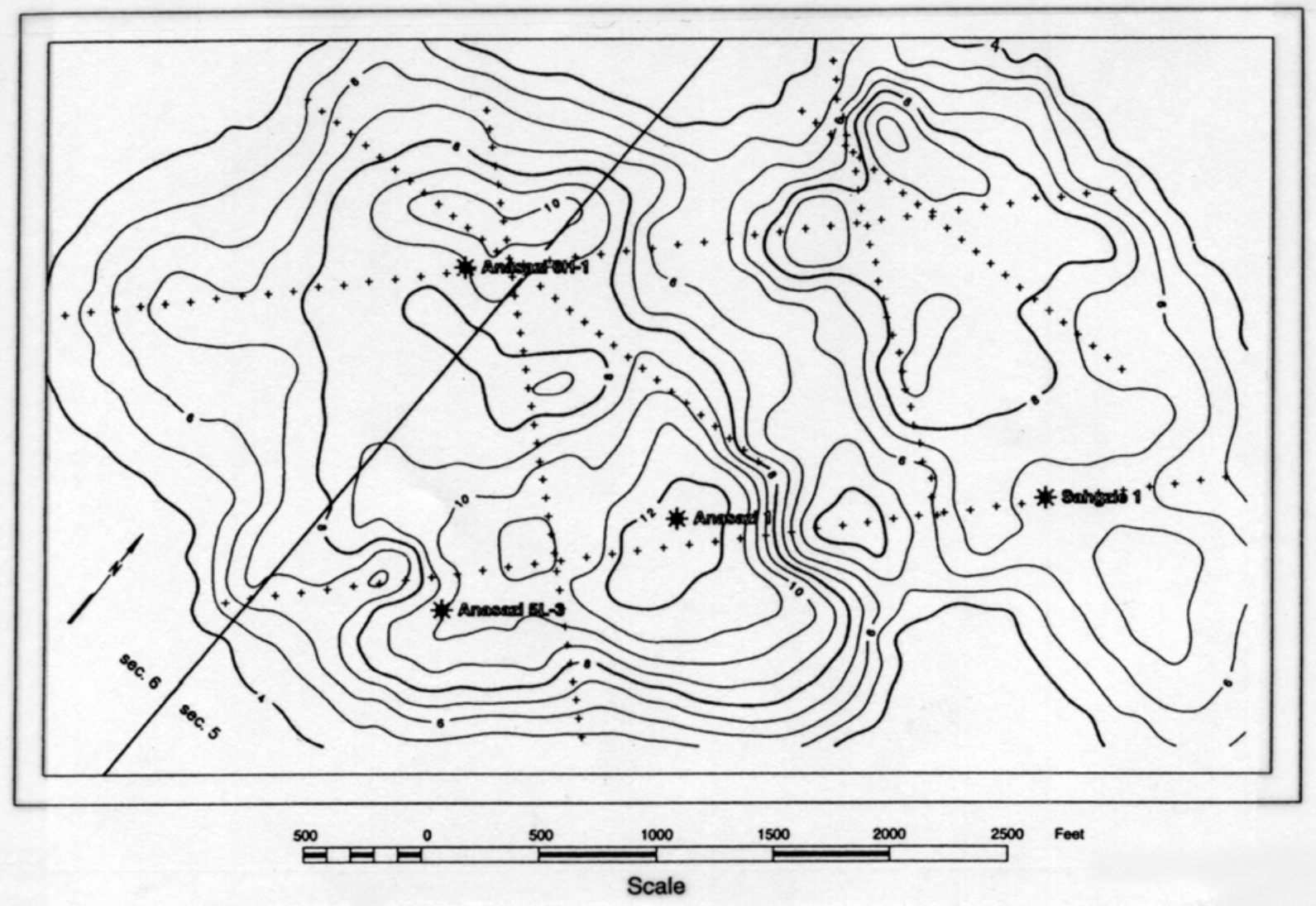

Figure 6-11. Map of average porosity derived from the RQI, Anasazi reservoir. Contour interval $=1$ percent; seismic data points $(+)$.

procedure termed "Boolean Emplacement"), then to rearrange individual grid blocks (under appropriate geological constraints) to improve conformance to the seismic-based average porosity constraint, and finally to generate local patterns of vertical and lateral porosity variation within each lithotype using conventional geostatistical methods (Sequential Gaussian Simulation). Permeability was generated from the modeled porosity using crossplot transfer functions developed from core data. At all stages of model development, the hard reservoir property data from the wells themselves was rigorously honored.

The data required to carry out the modeling procedures outlined above were obtained from a number of different sources. Information on architectural lithotypes, their averages and ranges of reservoir properties, stratigraphic distribution/succession, porosity/permeability relationships and layering/interface properties was based on logs and cores from the Anasazi wells. Geometric properties of the various architectural elements (for example packstone/ wackestone patches, tidal-channel grainstones, and mound-flank breccias) were obtained from the outcrop investigations. The average porosity constraint on lateral spatial variation was based on seismic interpretation. Inferred patterns of vertical variation within each lithotype were based on well logs and cores; patterns of lateral variation were developed from the outcrop studies and published information on Aneth field and its analogues (Best and others, 1995). 


\section{Geostatistical Models}

An initial set of ten geostatistical, equally probable representations of lithologic and reservoir properties in the Anasazi reservoir complex was generated. Based on borehole data and production tests from four wells, interpretations of the six two-dimensional seismic sections, well and field production data, and studies of geologically similar outcrop analogues, an extensive array of both hard and soft data constraints was developed and applied throughout the modeling process.

Reservoir model generation followed a five-stage procedure specifically designed for this project:

1. Monte Carlo generation of a 5 million-point, joint-probability distribution function (pdf) of the ten carbonate lithotype volumes identified in the Anasazi reservoir.

2. Using a random sample from this volume distribution, an initial model of reservoir architecture was obtained by stochastic emplacement of the various lithotype bodies within the reservoir volume. The sizes, shapes, orientations, and spatial distributions of these simple geometric bodies were constrained by observed data from wells, outcrops, and field analogues of modern carbonate facies.

3. Porosity values were then randomly assigned to each of these 75,000 individual lithotype blocks, constrained by the porosity pdf's developed for each lithotype from log and conventional core data. These porosity blocks were stochastically rearranged within the reservoir by simple gridblock exchange, using simulated annealing procedures to fit the vertically averaged reservoir porosity to the constraining porosity map based on the seismic-derived "reservoir quality index" (RQI). A secondary objective function, based on the vertical and lateral spatial covariance exhibited by porosity within the individual lithotypes in the Anasazi wells and in previous studies, also was fit to the model.

4. Horizontal and vertical permeability were estimated from the resulting porosities using randomized transfer functions developed from the Anasazi core data.

5. To accommodate typical computer workstation constraints, the 50-layer geostatistical reservoir models, (figures 6-12 and 6-13) were rescaled to 15 layers (figures 6-14 and 6-15). Although most major reservoir features were preserved (for example phylloid-algal limestones [bafflestones] in the mound-core interval [shown as uniformly dark-colored bodies in the illustrations] and thin, continuous and porous grainstones of the supra-mound interval [shown as light-to-medium colors] draped across the top of the mound core), some spatial continuity was altered in the rescaling process.

Of the ten equally probable geostatistical realizations of the reservoir model generated, one was selected for conducting the history matching phase of the reservoir simulation. Additional minor adjustments of the original model constraints were made in response to differences between the simulated reservoir behavior and observed production performance. 


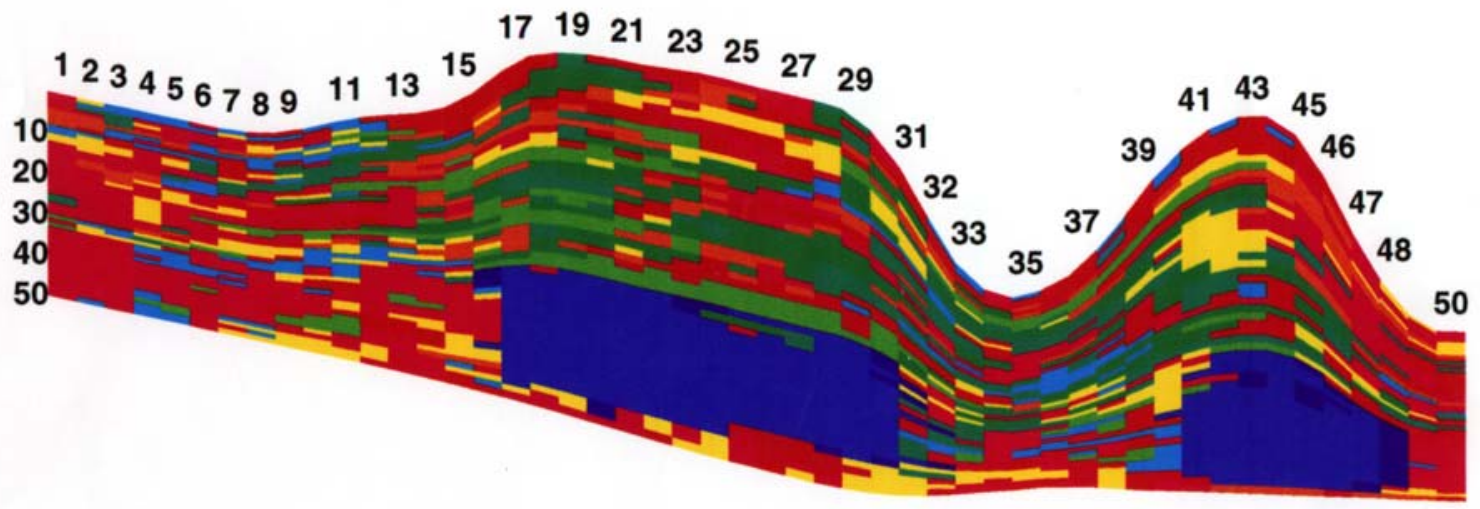

$1.0 \quad$ ROCK TYPES - SPATIAL VARIATION 10.0

FRONT XZ PLANE FOR $Y=20$

Figure 6-12. Cross section, through the Anasazi No. 1 well, of the 50-layer geostatistical Anasazi reservoir simulation model displaying the spatial distribution of lithotypes. Phylloid-algal limestones (bafflestones) in the mound-core interval are shown as uniformly dark-colored bodies. Thin, porous grainstones of the supra-mound interval draped across the top of the mound core are shown as light-to medium-colored bodies.

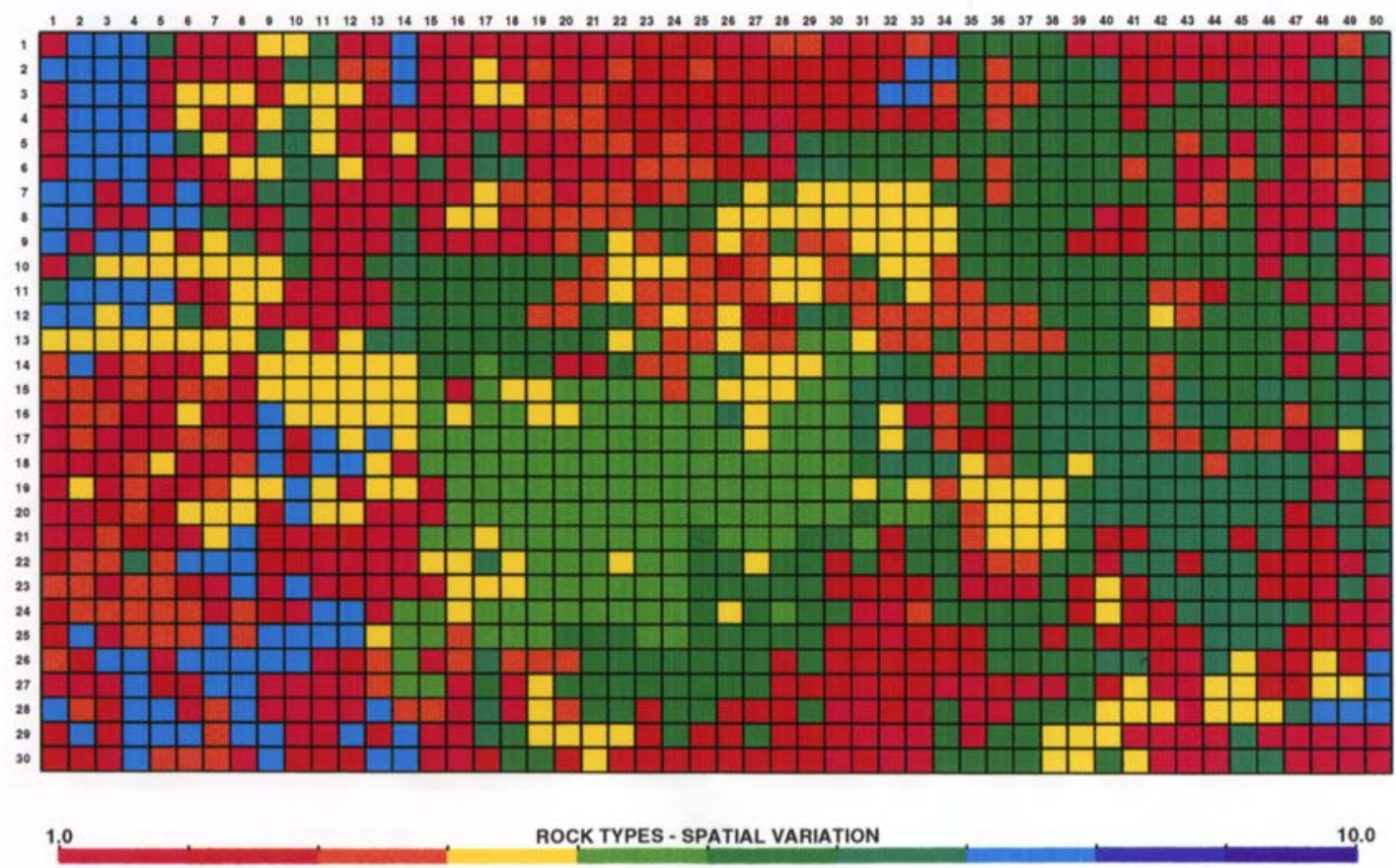

FRONT XY PLANE FOR $Z=30$

Figure 6-13. Spatial distribution of lithotypes at layer 30 from the 50-layer geostatistical Anasazi reservoir simulation model. 


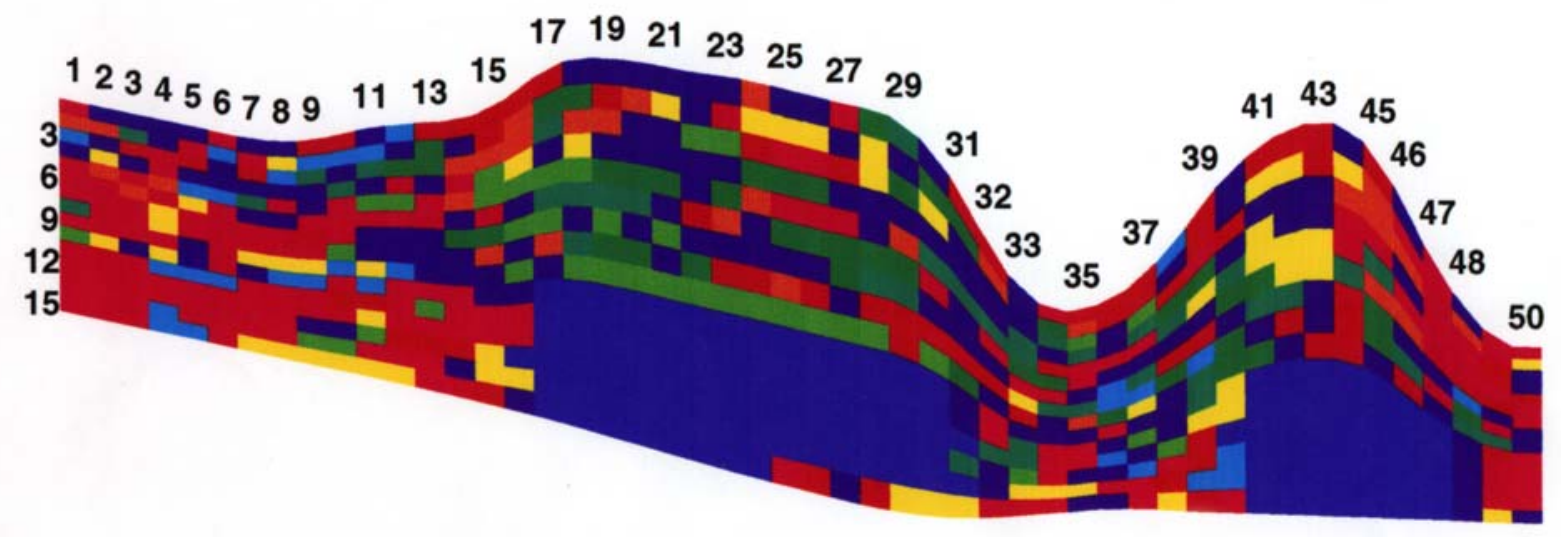

ROCK TYPES - SPATIAL VARIATION

10.0

\section{FRONT XZ PLANE FOR Y $=20$}

Figure 6-14. Cross section, through the Anasazi No. 1 well, of the 15-layer geostatistical Anasazi reservoir simulation model displaying the spatial distribution of lithotypes.

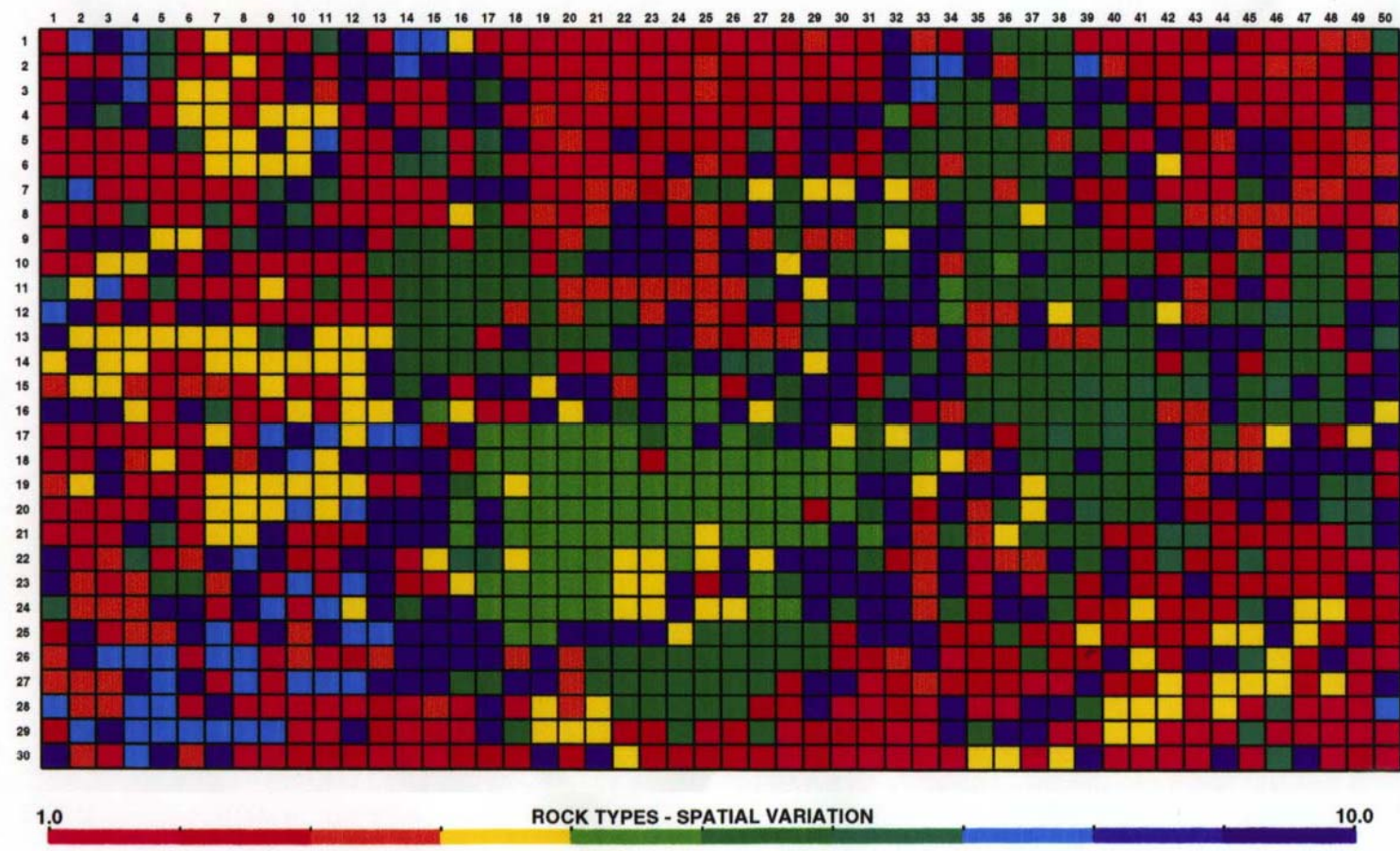

FRONT XY PLANE FOR Z $=9$

Figure 6-15. Spatial distribution of lithotypes at layer nine from the 15-layer geostatistical Anasazi reservoir simulation model.

When this process was completed, additional realizations were generated to represent the full range of possible configurations of internal architecture and distribution of reservoir properties, consistent with known reservoir production behavior. This final model was implemented in the predictive phases in the Anasazi reservoir performance simulation studies. 
Architectural modeling: The internal architecture of the reservoir between the wells was modeled using a marked-point (Boolean) process for emplacement of the 10 constituent lithotypes. This process was constrained by both the relative volumetric percentages of the various lithotypes observed in the wells and outcrops, and the average porosity map obtained from seismic interpretation. Simple rectangular geometries sufficed to represent the individual lithotype bodies, dimensions for which were described by triangular probability distributions. Fifteen geostatistical layers, each consisting of a 30 by 50 block grid (1,500 blocks per layer or a total of 22,500 blocks for the 15 layers), were used for reservoir modeling and flow simulation. Each grid block measures 105 feet square $\left(32 \mathrm{~m}^{2}\right)$ and varies between 3.5 and 7 feet (1-2 $\mathrm{m})$ in thickness. Emplacement sequences were established (for example cementation/ dissolution following emplacement of the unaltered lithotype) and the relative lithotype proportions varied stochastically.

Porosity modeling: The pair-wise, block-exchange process for simulating reservoir porosity between the Anasazi wells was carried out using a stochastic relaxation technique known as "simulated annealing." The method postulates an objective function computed from the model data prior to each proposed block exchange. This function is compared with a target value to determine whether the exchange would result in a closer match. If so, the exchange is made and the objective function updated. Even if the match would deteriorate slightly, the exchange can be accepted with a (specified) finite probability. As the process proceeds, this probability of accepting a slightly degraded porosity model declines.

The objective function for fitting the Anasazi reservoir porosity model consisted of the sum of two weighted components: (1) local spatial variation, and (2) global average reservoir porosity, estimated from the seismic reservoir-quality index. Local spatial variation of porosity was measured by horizontal and vertical variogram models based on data from analogous carbonate mound outcrops in the Ismay zone of the Paradox Formation along the San Juan River, Utah and the four Anasazi wells (Chidsey, Brinton, and Eby, 1996; Chidsey, Eby, and Lorenz, 1996).

Porosity was initially assigned randomly to each gridblock, the value selected from a probability distribution developed for each lithotype based on log, core, and outcrop data. Fitting to the variograms and average porosity constraints was achieved by block exchange, moderated by imposed requirements for maintaining architectural continuity of the previously emplaced lithotype bodies. Although the sizes, shapes, and geometric configurations of the individual architectural bodies were allowed to change, the total number of contiguous bodies was not. Thus, although the detailed geometries of the original simple lithotype units changed dramatically, the overall statistical properties of lithotype distribution were retained.

Several features of the geostatistical models are noteworthy. First, the mound-core and supra-mound intervals are clearly distinguished by the continuous development of the highly permeable phylloid-algal limestone in the mound-core interval, contrasted with the heterogeneous, less permeable but more porous mixed lithotypes draped over the core in the supra-mound interval. Second, much of the off-mound area was occupied by the three types of carbonate mudstone, while most of the supra-mound interval directly above the mound core consists of non-mud lithotypes. This is in keeping with lithotype distributions in the Anasazi wells and in the lower Ismay outcrops. Finally, although much of the inter-mound area contains either fine-grained, tight mudrocks or cemented skeletal grainstones, several layers of more porous and permeable grainstones, or enhanced porosity lithotypes, extend between the mound 
areas, both in the mound-core and supra-mound intervals. These "sheets" of better quality reservoir rock provide the communication between the mound-buildup areas required to allow the equalization of reservoir pressure observed during field development.

Fifteen-layer simulation model: Sensitivity studies were conducted which indicated that most of the variation in effective reservoir properties could be retained with careful scaling of porosity and permeability. Lithotypes were assigned to each of the 15-layer gridblocks according the dominant lithotype. Where no single lithotype predominated, the block was assigned to one of two new lithotype categories termed "poor quality" and "good quality" mixed lithologies. Porosity was volume-averaged for the 15-layer model, and effective permeability was computed by solution of the pressure equation using the VIP simulator. Distribution of lithotypes, porosity, and permeability for a typical realization of the final 15layer model are illustrated in the block diagrams (figures 6-16 through 6-18). Two, modeled, injector wells and the three producing wells (Anasazi No. 1, Anasazi No. 5L-3, and Sahgzie No. 1) are also shown.

\section{Runway Field}

The Desert Creek carbonate-mound buildup reservoir at Runway field (figure 1-1) was selected for a follow-up study to the completed Anasazi field reservoir assessment, both for comparison with those results, and also as a more promising candidate for a Phase II pilot demonstration due to the closer proximity of Runway to potential sources of injectable $\mathrm{CO}_{2}$. The pipeline that provides $\mathrm{CO}_{2}$ for the Greater Aneth field $\mathrm{CO}_{2}$ flooding program is 0.5 miles $(0.8 \mathrm{~km})$ southeast of Runway field. The Runway mound complex also had a long production history (more than seven years), a large amount of hard data for reservoir characterization (three logged wells, two of which are also cored through the Desert Creek zone), and had considerable seismic coverage. The reservoir also is more gas rich than the other project fields, and consists of both phylloid-algal and bryozoan buildup facies (Chidsey, Eby, and Lorenz, 1996).

\section{Geometry and General Stratigraphy}

The detailed, combined, structure/isopach map of the Desert Creek zone in the Runway area (figure 3-10) shows a Desert Creek mound buildup more than 50 feet $(15 \mathrm{~m})$ thick, based on well log and seismic information. Runway field is somewhat larger (193 acres [78 ha]) than Anasazi (165 acres [67 ha]) with a thicker average net pay (72 feet $(22 \mathrm{~m})$ and 57 feet $(17 \mathrm{~m})$, respectively) but lower average net pay porosity (11.9 percent and 14.1 percent, respectively) (Chidsey and others, 1996a, b). Three, previously drilled, dry holes nearby provide off-mound thickness, lithology, and porosity data.

The reservoir consists of a combination of bryozoan-buildup and phylloid-algal-buildup intervals. A variety of carbonate facies is encountered in all three Runway wells that cause a high degree of spatial heterogeneity in reservoir properties. Conventional cores from Runway field contain 15 to 19 lithologic units (figure 3-5). Some units exhibit partial to complete dolomitization; late anhydrite plugging is also present. Pore types in these rocks include moldic, intercrystalline, and vuggy. At least three flooding surfaces are present and are likely barriers or baffles to fluid flow. Extensive karstification and solution-collapse brecciation has occurred in some of the middle to upper units. 


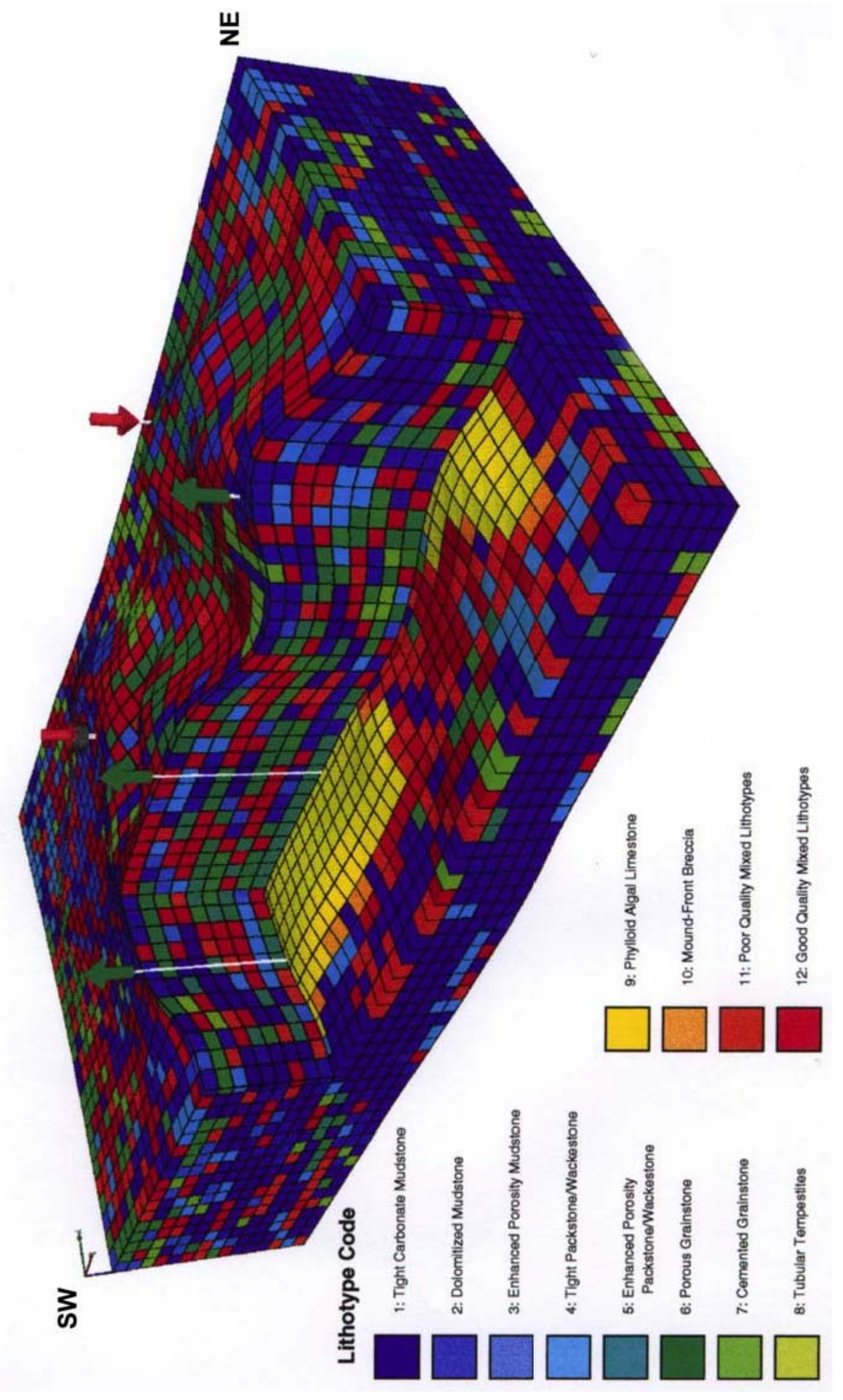

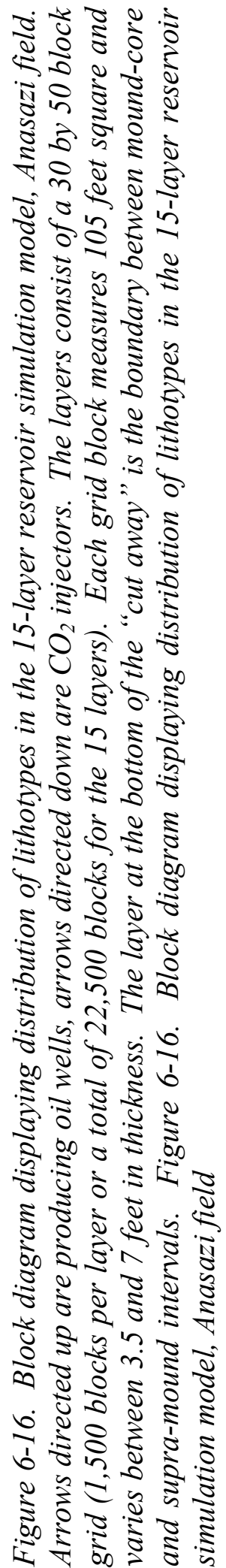



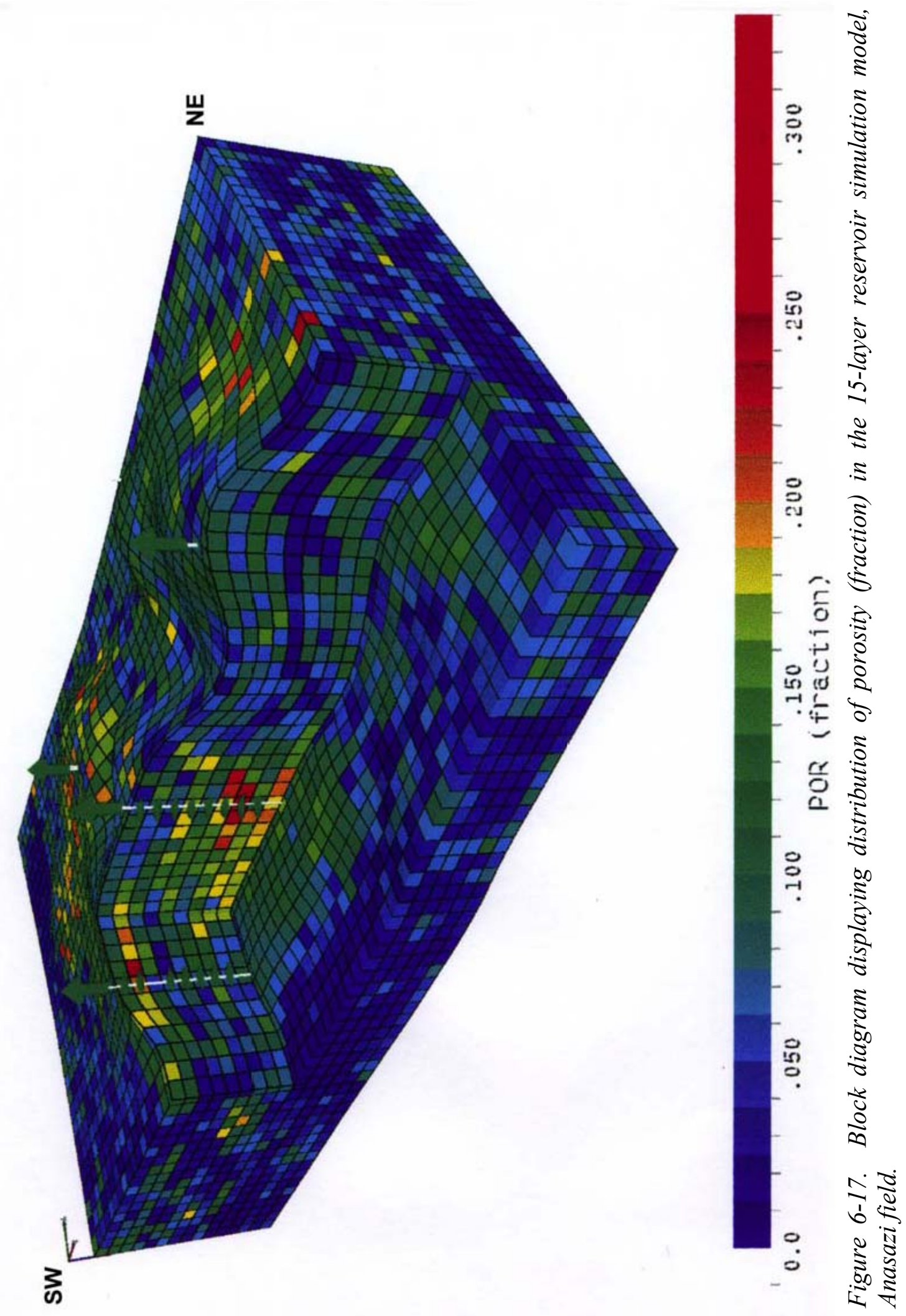

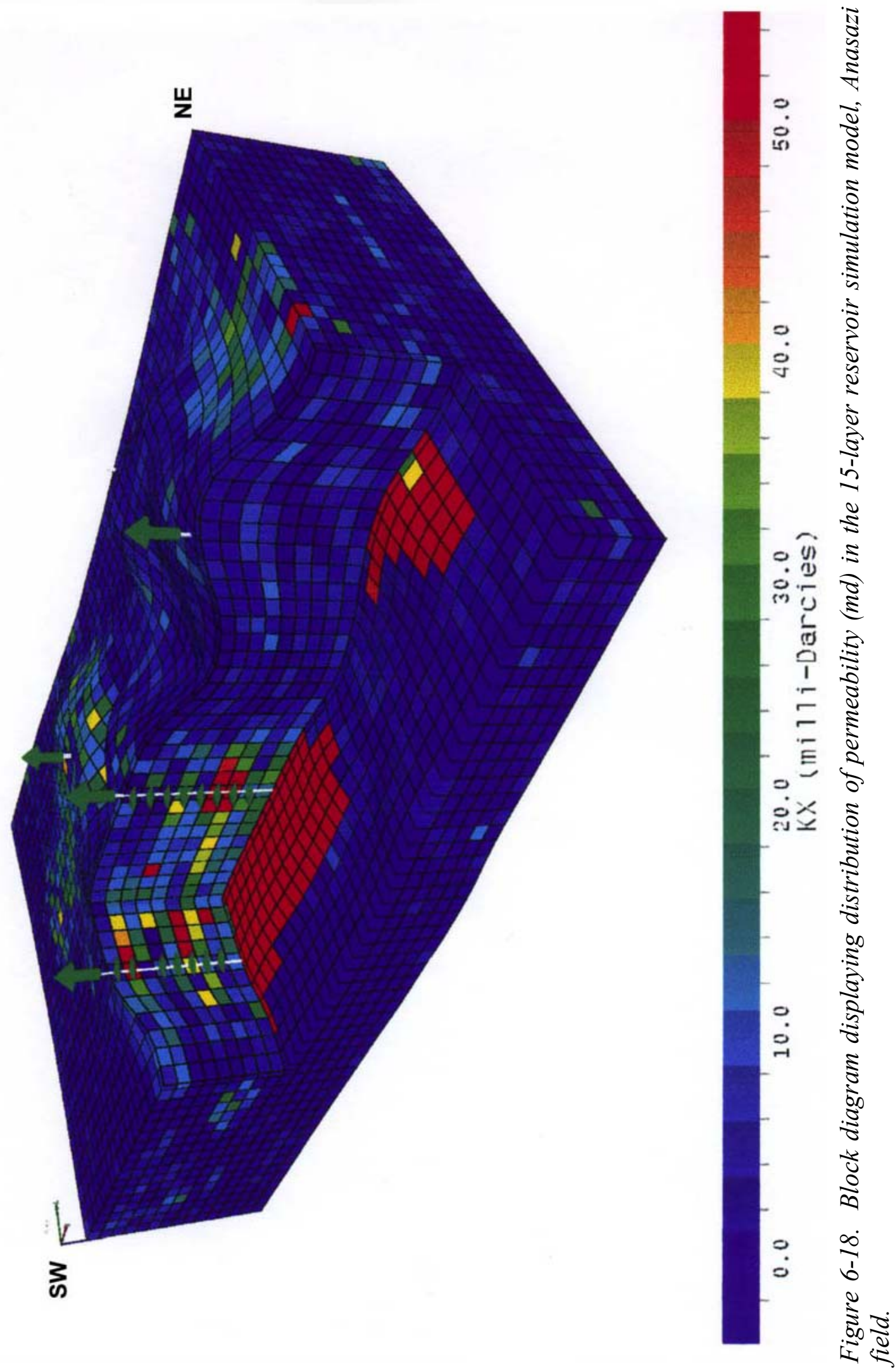
The principal Desert Creek reservoir lithotypes in the bryozoan-dominated interval are bindstones and framestones. The principal reservoir lithotypes in the phylloid-algal-mound interval are porous lime bafflestones with some grainstones. Both carbonate buildups are interbedded with low-permeability wackestones and mudstones. Dolomitization has enhanced the reservoir potential of several lithotypes.

\section{Reservoir Architecture}

The three-fold subdivision of the Anasazi carbonate-mound buildup into platform, mound-core, and supra-mound intervals is also present at Runway, although the carbonate lithotypes are somewhat different. At least three distinct mound-building episodes (first by phylloid algae, followed by fenestrate bryozoa, and phylloid algae again) are represented in the Runway reservoir. Primary carbonate stratigraphy is less heterogeneous at Runway than at Anasazi, although the supra-mound interval in the thickest parts of the mound have undergone a great deal of secondary solution collapse brecciation, as seen in core from the Runway No. 10E-2 well.

As at Anasazi field, significant heterogeneity in both the lithotypes and the reservoir properties at Runway field requires development of a multi-stage procedure for incorporating the variation observed in conventional cores from the field into the reservoir geostatistical model. Geostatistical modeling of the Runway reservoir incorporates unit thicknesses, flooding surfaces, and lithotypes observed in the core. The significant spatial heterogeneity exhibited by both the lithotypes and the Desert Creek reservoir properties at Runway field required development of a multi-stage procedure for incorporating the variation observed from outcrop analogues into the reservoir model. Based on detailed examination of the cores and log data, and field observations from the Lower Ismay outcrop analogues, it was determined that a 50layer geostatistical model would adequately capture the lithologic variability in the platform, mound-core, and supra-mound intervals (Chidsey, Eby, and Lorenz, 1996; Chidsey, Brinton, Eby, and Hartmann, 1996; Chidsey and others, 1996a). Observed lithologic, porosity, and permeability data from the three Runway wells were incorporated into the layering at the well locations. These model "conditioning" data were fixed throughout the subsequent modeling process.

Although the mound-core interval of the Runway field's Desert Creek reservoir is predominantly phylloid-algal and bryozoan limestones, the overlying supra-mound dolomites and limestones exhibit a variety of lithotypes. A series of ten distinct lithotypes was identified within the Desert Creek reservoir. These lithotypes include carbonate mudstones, packstones/ wackestones, grainstones, mound-building algal and bryozoan limestones, and solution collapse breccias. Several lithotypes are characterized by enhanced porosity and/or dolomitization.

\section{Reservoir Modeling Geometry}

Although three-dimensional seismic data have not been acquired over Runway field, two sets of closely spaced swath lines have provided the data for defining the geometry and average porosity of the Desert Creek carbonate-mound reservoir with greater confidence than was possible at Anasazi. The carbonate-mound buildup isolith map (figure 6-19) was obtained by time-depth conversion on the top and base of the Desert Creek zone, and tied to the three Runway wells plus six other wells in the vicinity. The thickness of the smoothly varying 
anhydrite at the top of the Desert Creek was subtracted to produce the carbonate reservoir isolith map. Average porosity (figure 6-20) was obtained from the seismic amplitude data. The porosity grid was also tied to the well data used in the isolith map and thickness effects were deleted. Figures 6-19 and 6-20 clearly depict the Runway carbonate-mound buildup, with the best reservoir quality (as represented by average porosity) closely corresponding to the buildup areas.

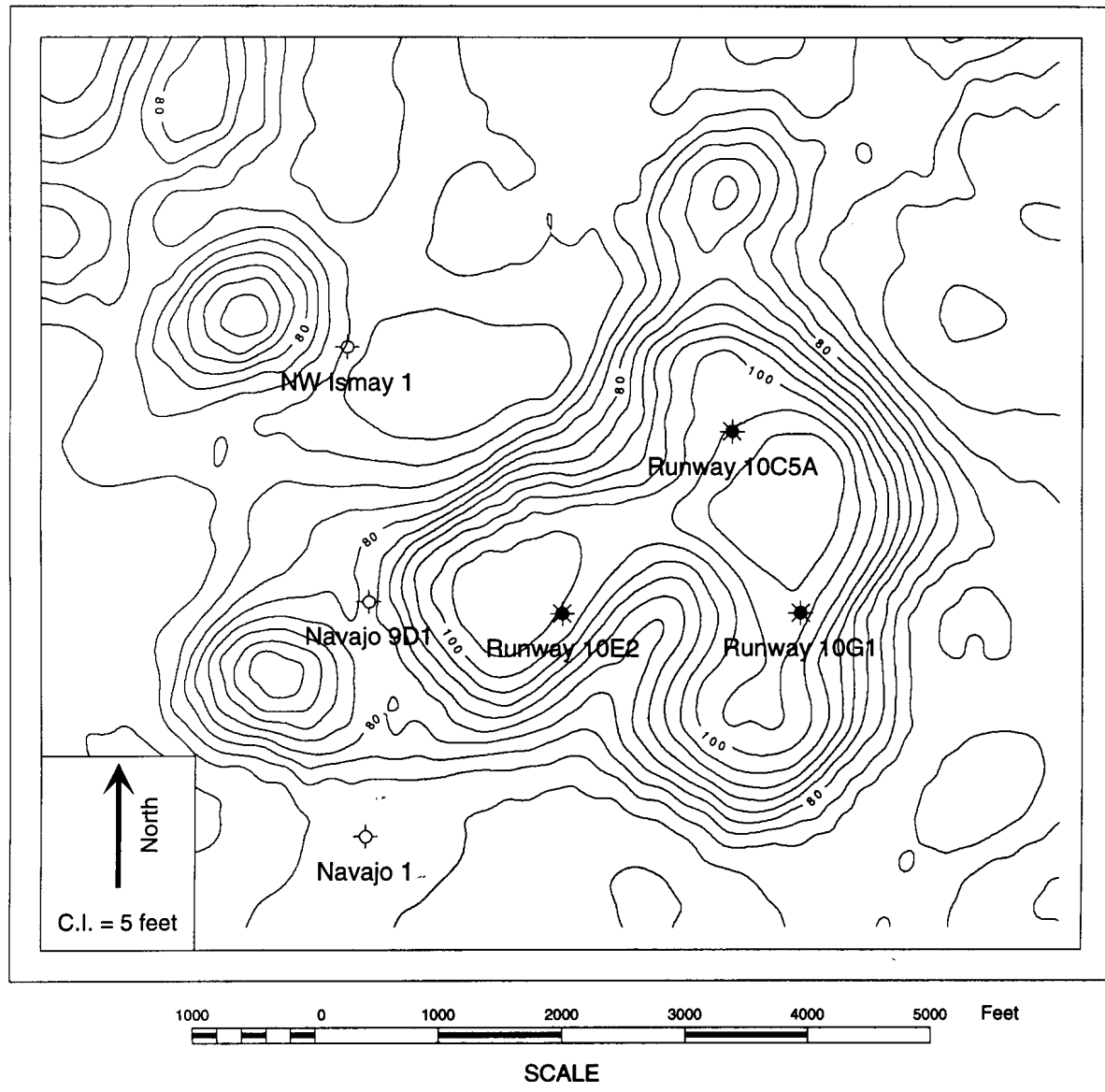

Figure 6-19. Carbonate isolith map of the Desert Creek reservoir, Runway field.

The size and shape of the mound-buildup area, the inferred areal extent of lithotype architectural bodies known to be present in the reservoir, and the constraints imposed by numerical modeling provided the framework for defining the areal grid for the Runway reservoir characterization and simulation model (figure 6-21). This model consists of 36 rows and 42 columns of grid cells, each measuring 180 feet square $\left(55 \mathrm{~m}^{2}\right)$ (figure 6-21). The $42 \times 36$ areal grid just spans the reservoir buildup, encompassing an area of 1,125 acres (455 ha). As at Anasazi, the Desert Creek carbonate interval was subdivided into 50 equal-thickness layers, ranging from 1.3 feet $(0.4 \mathrm{~m})$ thick in the off-mound areas to 2.3 feet $(0.7 \mathrm{~m})$ in the thickest part of the mound. Because one well (Runway No. 10-G-1) also produces from the upper Ismay zone of the Paradox Formation, two additional layers are included in the model, one 60-foot (18-m) layer for the Ismay carbonate reservoir, and a 115-foot (35-m) inactive layer representing the average non-reservoir interval between the top of the Desert Creek carbonates and the base of the upper Ismay over Runway field. 


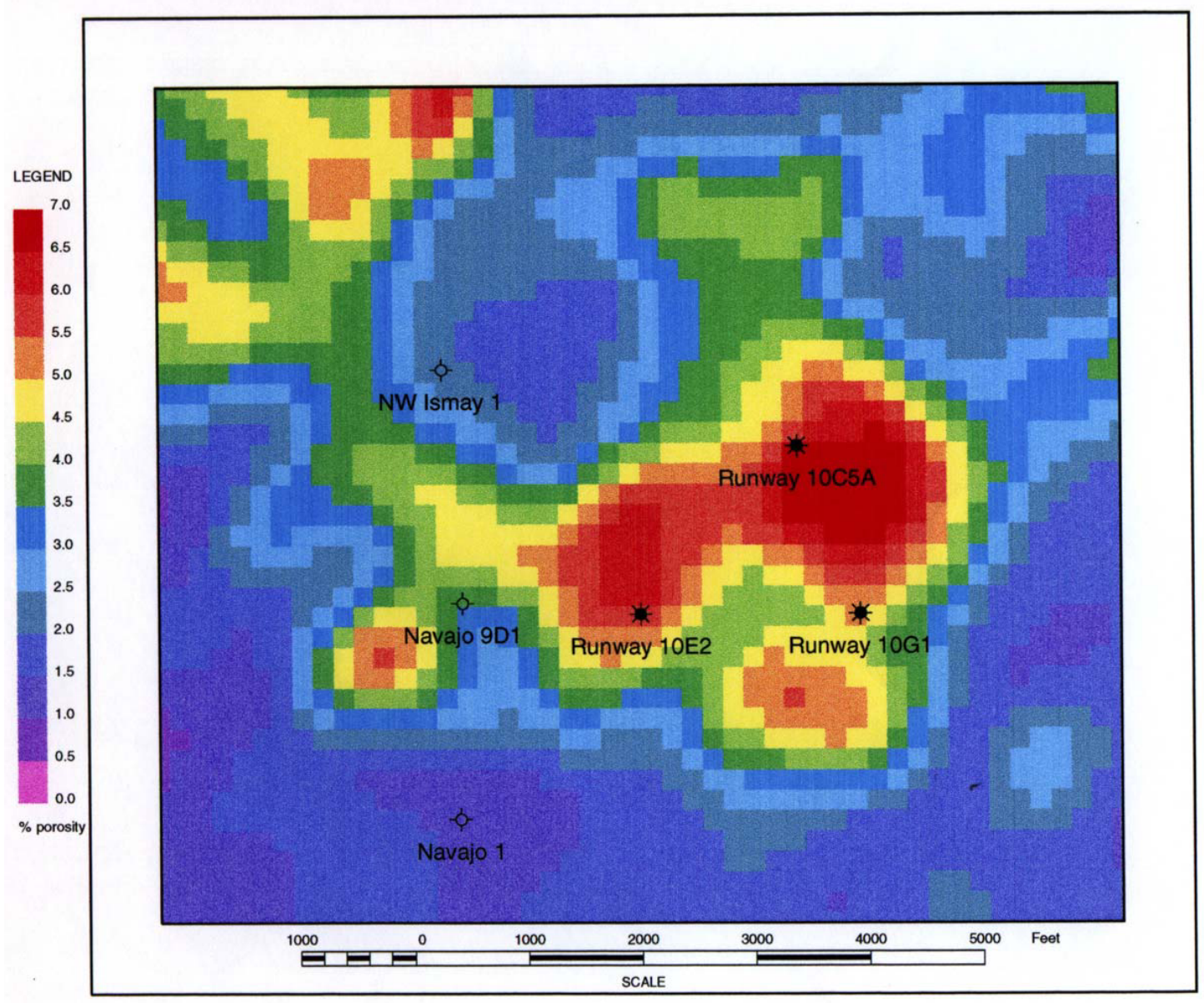

Figure 6-20. Average porosity grid of the Desert Creek reservoir, Runway field.

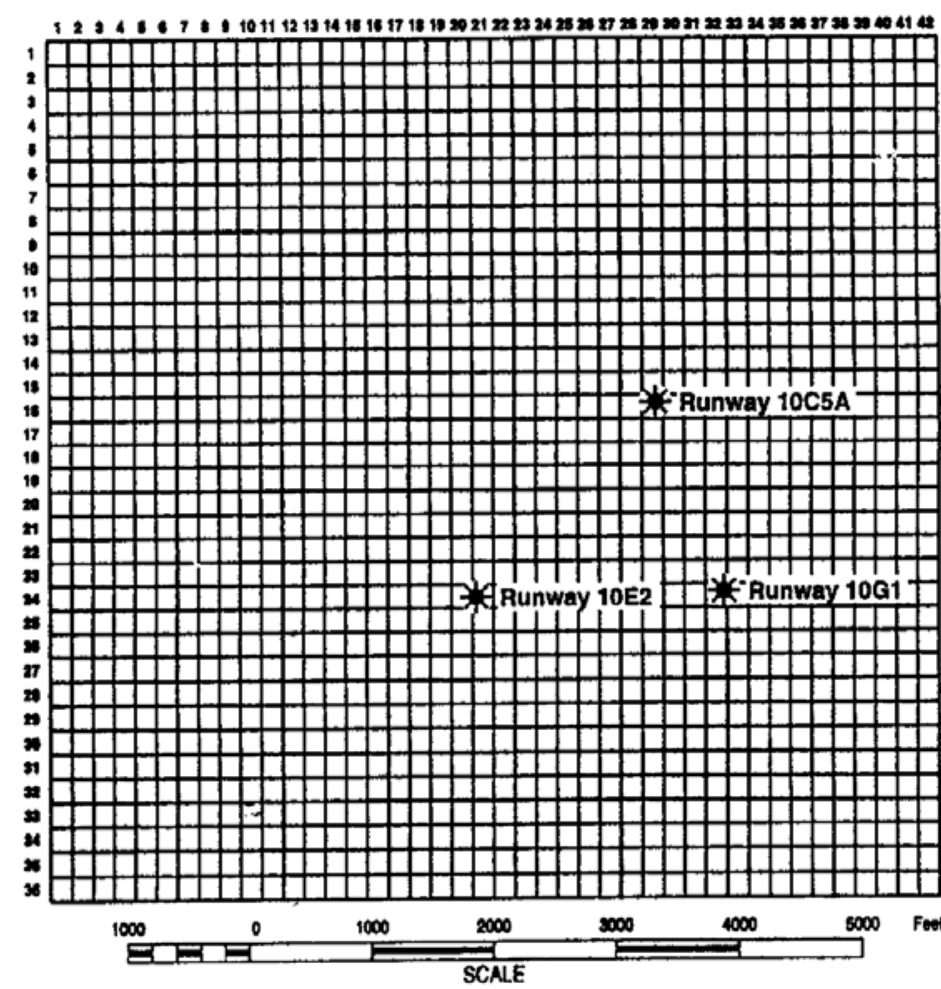

Figure 6-21. Runway field simulation grid and well locations. 


\section{Reservoir Model Design}

The internal architecture of the Desert Creek reservoir was modeled between the wells using a marked-point (Boolean) process for emplacement of the ten constituent lithotypes (figure 6-22). In the mound-core interval, the phylloid-algal and bryozoan limestones were emplaced deterministically, corresponding to the seismic buildup isolith. These reservoir partitions were then populated with porosities, using layer-averaged statistical distributions obtained from the well log and core data. The spatial distribution of porosity was fitted to the average porosity grid (figure 6-20). The initial architectural model was modified by pair-wise exchange of gridblocks to fit porosity constraints of both local spatial variation and overall (global) average porosity distribution grid derived from seismic amplitudes (figure 6-23). The pair-wise, block-exchange process for simulating Desert Creek reservoir porosity between the Runway wells was carried out using the well-known stochastic relaxation technique, "simulated annealing."
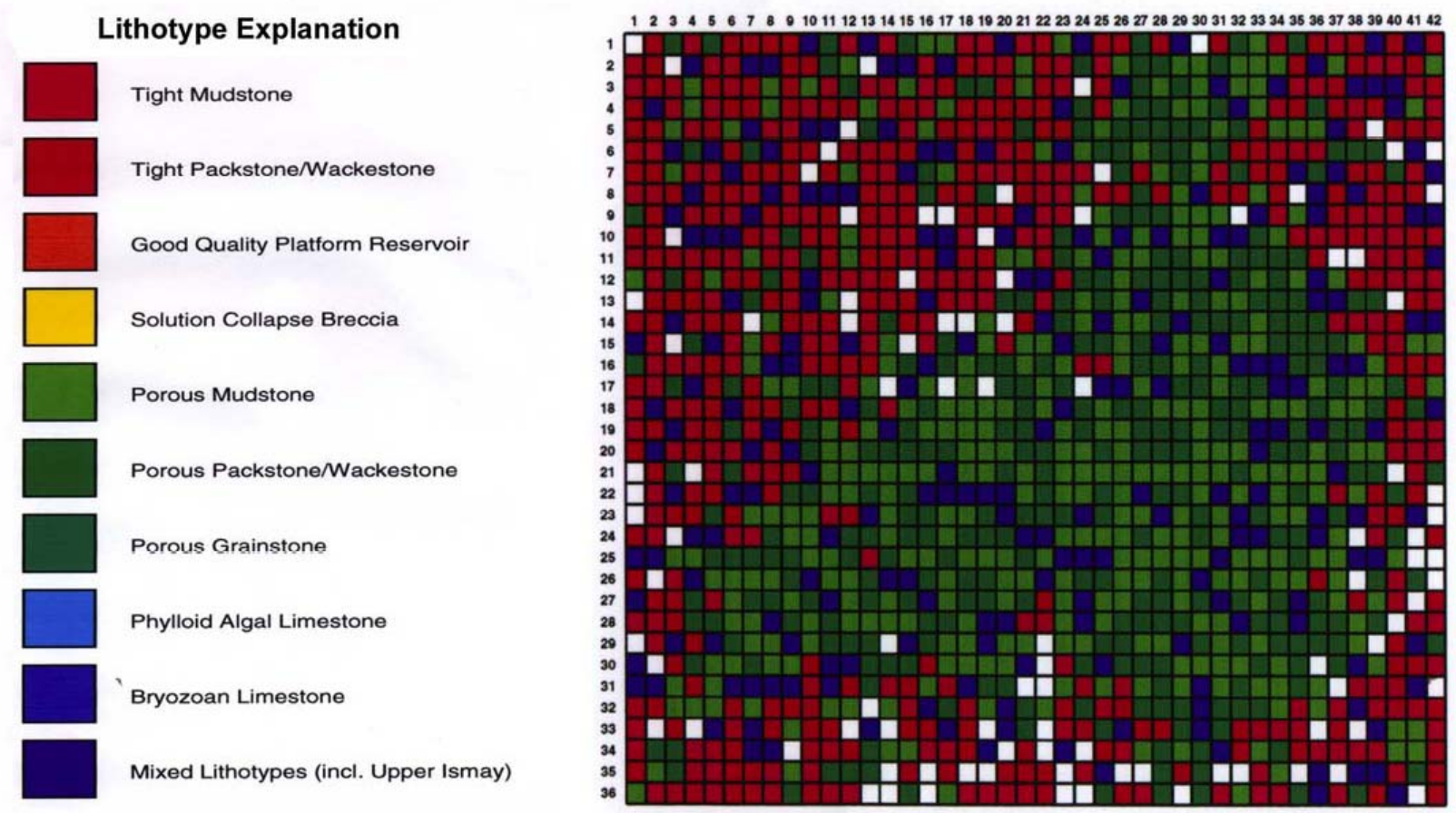

Figure 6-22. Spatial distribution of lithotypes at Layer 4 (supra-mound interval) from the 17layer geostatistical Runway reservoir simulation model.

A total of 50 equally probable realizations of this hybrid model were generated, and horizontal and vertical permeabilities estimated using porosity/permeability correlations from core data. These 50 cases were ranked according to a statistical measure of reservoir connectivity. A subset of three or four realizations representing the predominant types of connectivity was selected, the Desert Creek interval vertically up-scaled to 10 layers, and short simulation sensitivity runs carried out to evaluate the impact of heterogeneity on reservoir behavior. The case most representative of the observed reservoir heterogeneity and connectivity was selected for conducting the flow-simulation history match and reservoir performance predictions. 


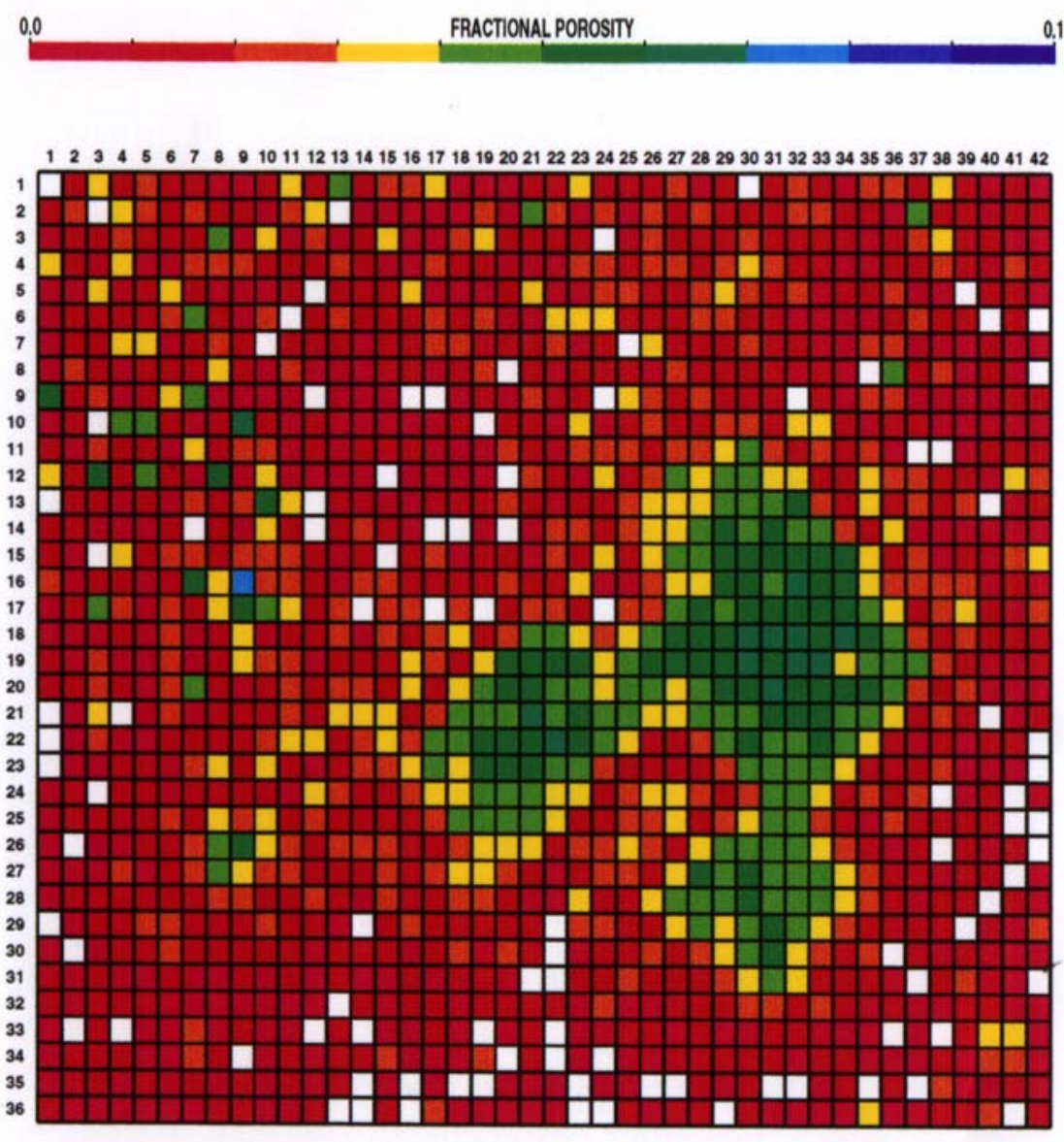

Figure 6-23. Spatial distribution of porosity (fractional) at Layer 4 from the 17-layer geostatistical Runway reservoir simulation model.

\section{Geostatistical Models}

A total of 20 preliminary geostatistical models were generated for sensitivity studies of the impact of reservoir continuity on production performance. Several features of the 50-layer geostatistical models are noteworthy. First, the platform, mound-core, and supra-mound intervals are clearly distinguished; the continuously developed, highly permeable phylloid-algal and bryozoan limestones in the mound core contrast sharply with the heterogeneous, less permeable but more porous mixed lithotypes in the underlying platform interval and the overlying supra-mound interval (figure 6-24). Second, much of the off-mound area is occupied by carbonate mudstone, while most of the supra-mound interval directly above the mound core consists of non-mud lithotypes. This is in keeping with lithotype distributions in the Runway wells and in the lower Ismay outcrops. In contrast to the previously studied Desert Creek carbonate mound reservoir at Anasazi field (figure 1-1), the best quality supra-mound lithotype (porous grainstone) bodies are largely restricted to the mound area, and do not extend far out into the adjacent off-mound areas as detrital "aprons." This is consistent with the generally deeper-water environment inferred from the presence of bryozoan limestones at Runway field (Chidsey, Eby, and Lorenz, 1996). 


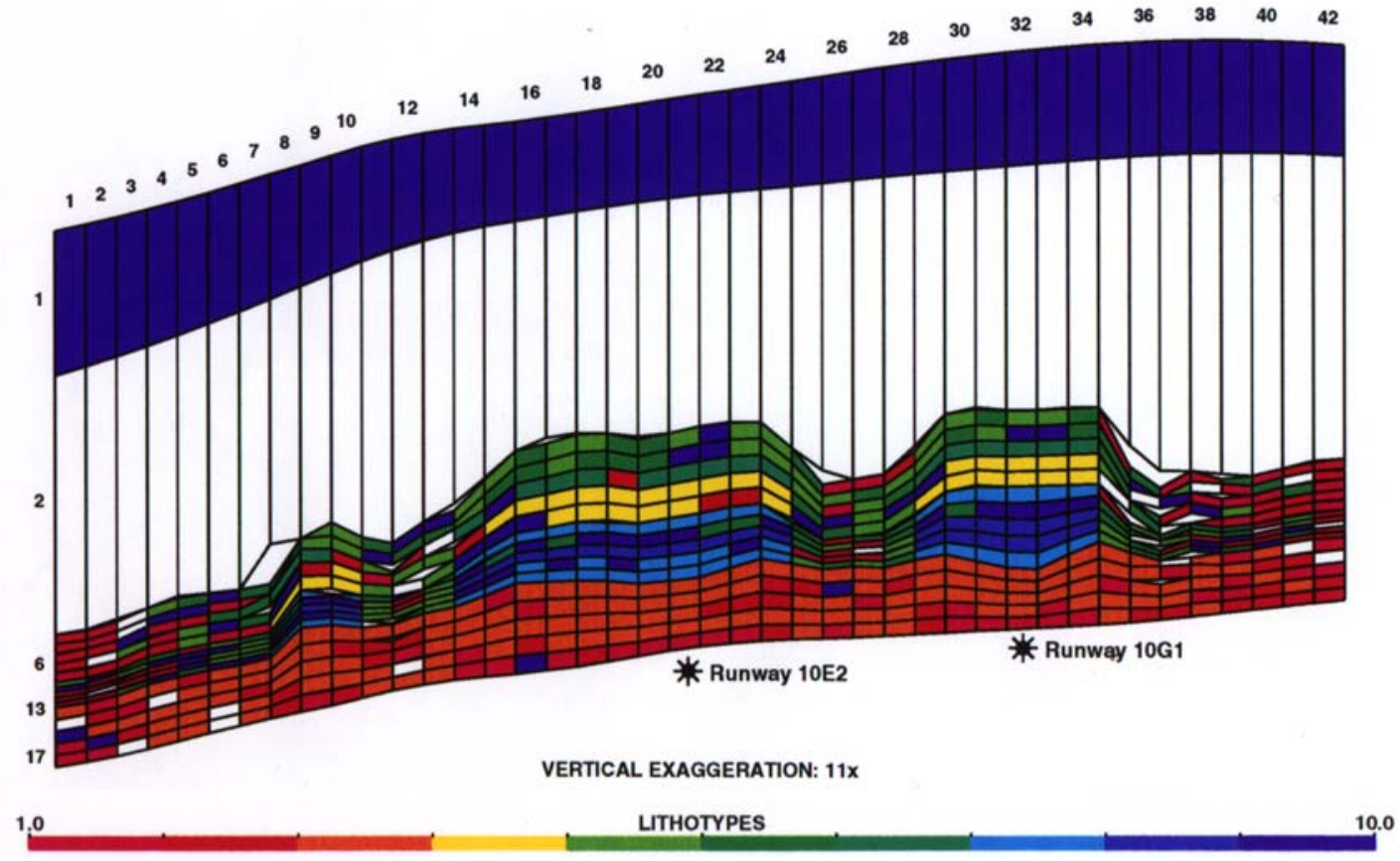

Figure 6-24. East-west cross section, through the Runway Nos. 10E-2 and 10G-1 wells, of the 17-layer geostatistical Runway reservoir simulation model displaying the spatial distribution of lithotypes in the Desert Creek and Ismay zones. See figure 6-22 for explanation of lithotypes.

Finally, because of computer flow-simulation runtime limitations, the number of layers in the Desert Creek reservoir model was reduced from 50 to 15 . Sensitivity studies indicated that most of the variation in effective properties could be retained with careful scaling of porosity and permeability. Lithotypes were assigned to each of the 15-layer gridblocks according to the dominant lithotype in the corresponding 3.5 layers of the parent 50-layer geostatistical model. Porosity was volume-averaged for the 15-layer model, and effective permeability was computed by solution of the pressure equation using the field-scale reservoir simulator.

In addition to the Desert Creek carbonate mound reservoir, the lower dolomite in the upper Ismay is perforated and under production in the Runway No. 10G-1 well. This separate upper Ismay reservoir is isolated from the Desert Creek reservoir by as much as 115 feet (35.1 $\mathrm{m}$ ) of non-producing section comprised of the Desert Creek anhydrite, Gothic shale, lower Ismay carbonates, and Hovenweep shale. In the final Runway reservoir model, the upper Ismay reservoir is designated as Layer 1, and the intervening interval isolating the Desert Creek and upper Ismay reservoirs is Layer 2; thus, the final model consists of a total of 17 layers. 


\title{
CHAPTER VII \\ ENGINEERING RESERVOIR CHARACTERIZATION OF THE CARBONATE RESERVOIR IN THE DESERT CREEK ZONE
}

\author{
W.E. Culham \\ REGA Inc.
}

\section{Introduction}

Before reservoir simulation studies could be conducted using the statistical models for Anasazi and Runway fields, additional engineering data were required. These data were compiled through two principal tasks:

1. review of existing field data including re-evaluation of well-test data, and

2. reservoir fluid and rock characterization via an extensive laboratory program.

The results of these tasks are summarized in the following sections. Raw data (compositional analyses of oil and gas, and swelling tests) can be found in the appendices of Chidsey (1997).

\section{Review of Existing Field Data and Re-evaluation of Well Test Data}

\section{Basic Reservoir Engineering Analysis of the Five Project Fields}

Basic reservoir parameters for the Anasazi, Blue Hogan, Heron North, Mule, and Runway fields were compiled from the following sources: (1) geophysical well logs, (2) core analyses, (3) compressibility tests on carbonates from the Anasazi Nos. 1 and 6H-1 wells, (4) pressure-volume-temperature (PVT) tests, (5) oil and gas analyses, (6) reservoir mapping, and (7) monthly production reports from the Utah Division of Oil, Gas and Mining. The results are summarized on tables 7-1 and 7-2. Production histories were also plotted for each field. These plots include monthly oil, gas, and water production, and number of producing wells (figure 7$1)$.

This information was merged with geological characterization data and incorporated into reservoir statistical models and simulations. Utilizing the results, sweep efficiencies for various secondary/tertiary recovery methods, and the ultimate enhanced recovery were estimated for all five fields.

\section{Field Data Review}

Basic field information reviewed for this study also a review of special core tests (such as relative permeability data) and fluid characterization studies on associated Paradox Basin reservoirs.

Historic production data for individual wells in the field were reformatted into data files for use during simulation work to provide a basis for comparing actual historic well/field performance versus simulated data to facilitate the history matching. 
Table 7-1. Petrophysical properties and pressure data for project fields.

\begin{tabular}{|c|c|c|c|c|c|c|c|c|c|c|c|}
\hline \multirow[t]{2}{*}{ Field } & \multirow[t]{2}{*}{$\begin{array}{c}\text { Average } \\
\text { Porosity } \\
(\%)\end{array}$} & \multirow[t]{2}{*}{$\begin{array}{c}\text { Average } \\
\text { Permeability } \\
\text { (md) }\end{array}$} & \multicolumn{2}{|c|}{$\begin{array}{l}\text { Pore Volume } \\
\text { Compressibility } \\
\text { (Cpu 10-6/ psi) }\end{array}$} & \multicolumn{2}{|c|}{$\begin{array}{l}\text { Reservoir } \\
\text { Pressure }\end{array}$} & \multirow[t]{2}{*}{$\begin{array}{c}\text { Water } \\
\text { Saturation } \\
(\%)\end{array}$} & \multirow{2}{*}{$\begin{array}{c}\text { Initial } \\
\text { Gas-Oil } \\
\text { Ratio } \\
\text { (scf/STB) }\end{array}$} & \multirow{2}{*}{$\begin{array}{l}\text { Initial Formation } \\
\text { Volume } \\
\text { Factor (reservoir } \\
\text { bbls/STB) }\end{array}$} & \multirow{2}{*}{$\begin{array}{l}\text { Bubble } \\
\text { Point } \\
\text { Pressure } \\
\text { (psig) }\end{array}$} & \multirow[t]{2}{*}{$\begin{array}{c}\text { Type of } \\
\text { Drive }\end{array}$} \\
\hline & & & Limestone & Dolomite & $\begin{array}{l}\text { Initial } \\
\text { (psig) }\end{array}$ & \begin{tabular}{|c}
$\begin{array}{c}\text { Present } \\
\text { (psi) }\end{array}$ \\
\end{tabular} & & & & & \\
\hline Anasazi & 14.1 & $\begin{array}{c}190 \text { for mound } \\
\text { core } \\
2 \text { for supra- } \\
\text { mound }\end{array}$ & 2.3329 & 3.1849 & 1,945 & $200-300$ & 15 & $364: 1$ & 1.199 & 1,023 & $\begin{array}{c}\text { Gas } \\
\text { Expansion }\end{array}$ \\
\hline $\begin{array}{c}\text { Blue } \\
\text { Hogan }\end{array}$ & 9.1 & $\begin{array}{c}190 \text { for mound } \\
\text { core } \\
2 \text { for supra- } \\
\text { mound }\end{array}$ & 2.3329 & 3.1849 & 1,800 & $200-300$ & 15 & $487: 1$ & 1.260 & 1,590 & $\begin{array}{c}\text { Gas } \\
\text { Expansion }\end{array}$ \\
\hline $\begin{array}{l}\text { Heron } \\
\text { North }\end{array}$ & 15 & 17.7 & ND & ND & 1,934 & $200-300$ & 15 & 644:1 & 1.328 & 1,922 & $\begin{array}{c}\text { Gas } \\
\text { Expansion }\end{array}$ \\
\hline Mule & 13 & $\begin{array}{c}190 \text { for mound } \\
\text { core } \\
2 \text { for supra- } \\
\text { mound }\end{array}$ & 2.3329 & 3.1849 & 2,050 & $200-300$ & 15 & $478: 1$ & 1.240 & 1,478 & $\begin{array}{c}\text { Gas } \\
\text { Expansion }\end{array}$ \\
\hline Runway & 11.9 & 17.3 & ND & ND & 2,162 & $200-300$ & 15 & $967: 1$ & 1.511 & 2,141 & $\begin{array}{c}\text { Gas } \\
\text { Expansion }\end{array}$ \\
\hline
\end{tabular}

$\mathrm{ND}=$ No Data

Table 7-2. Oil, gas, and water properties for project fields.

\begin{tabular}{|c|c|c|c|c|c|c|}
\hline Field & $\begin{array}{c}\text { Bottom-hole } \\
\text { Temperature } \\
\left({ }^{\circ} \text { F) }\right.\end{array}$ & $\begin{array}{c}\text { Resistivity of } \\
\text { Water } \\
(\text { ohm-m @ BHT) }\end{array}$ & $\begin{array}{c}\text { Oil Gravity } \\
\left({ }^{\circ} \mathbf{A P I}\right)\end{array}$ & $\begin{array}{c}\text { Oil Viscosity } \\
\text { (cP @ initial } \\
\text { reservoir conditions) }\end{array}$ & $\begin{array}{c}\text { Gas Heating } \\
\text { Value (Btu/ft }{ }^{3} \text { ) }\end{array}$ & $\begin{array}{c}\text { Gas Specific } \\
\text { Gravity (decimal } \\
\text { fraction) }\end{array}$ \\
\hline Anasazi & $138^{\circ}$ @ 5,777' & 0.035 & 41 & 0.951 & $1,400.3$ & 0.8080 \\
\hline Blue Hogan & $128^{\circ} @ 5,613^{\prime}$ & 0.035 & 40.6 & 0.811 & $1,497.0$ & 0.8992 \\
\hline Heron North & $126^{\circ} @$ @ 5,752' & 0.035 & 44.0 & 0.475 & $1,321.0$ & 0.8335 \\
\hline Mule & $128^{\circ} @ 5,804^{\prime}$ & 0.035 & 44.0 & ND & $1,539.0$ & 0.8890 \\
\hline Runway & $126^{\circ} @$ @ 6,203' & 0.070 & 40.5 & 0.314 & $1,356.5$ & 0.7790 \\
\hline
\end{tabular}

ND $=$ No Data

Review of relative permeability data (only one study involving cores from Runway and Anasazi was available) provided the basis for assessing the validity of existing data based on new comprehension wettability and relative permeability measurements (discussed later).

The review of the fluid properties studies provided the basis for identifying appropriate data sets to incorporate into equation of state which was further tuned by employing newly derived fluid property data. This review identified basic "black oil" pressure-volumetemperature (PVT) studies from seven different reservoirs (Anasazi, Mule, Blue Hogan, Brown Hogan, Heron North, Runway, and Jack fields [figure 1-1]) that were available for analysis. A review of compositions, bubble point pressures, and solution gas-oil ratios identified only the Jack field as being appropriate to integrate with existing Anasazi and Runway data and the newly generated fluid characterization information. As discussed below, the data sets whave been integrated with the newly generated data to "tune" an equation of state for use in the compositional simulation work. 

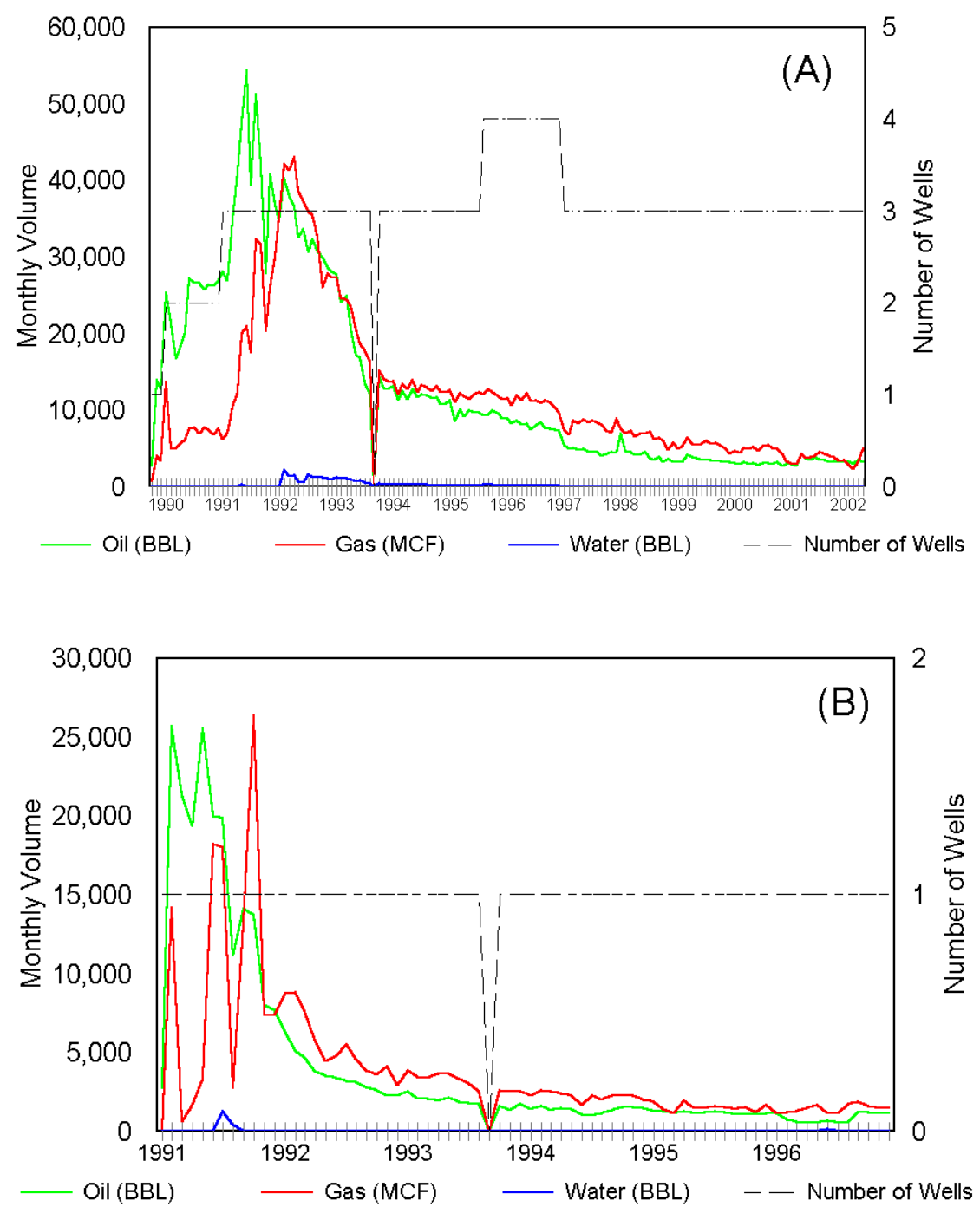

Figure 7-1. Annual production graphs as of January 1, 2002 for the (A) Anasazi, (B) Blue Hogan, (C) Heron North, (D) Mule, and Runway (E) fields, San Juan County, Utah, Navajo Nation. Production data from the Utah Division of Oil, Gas and Mining, 2002. 

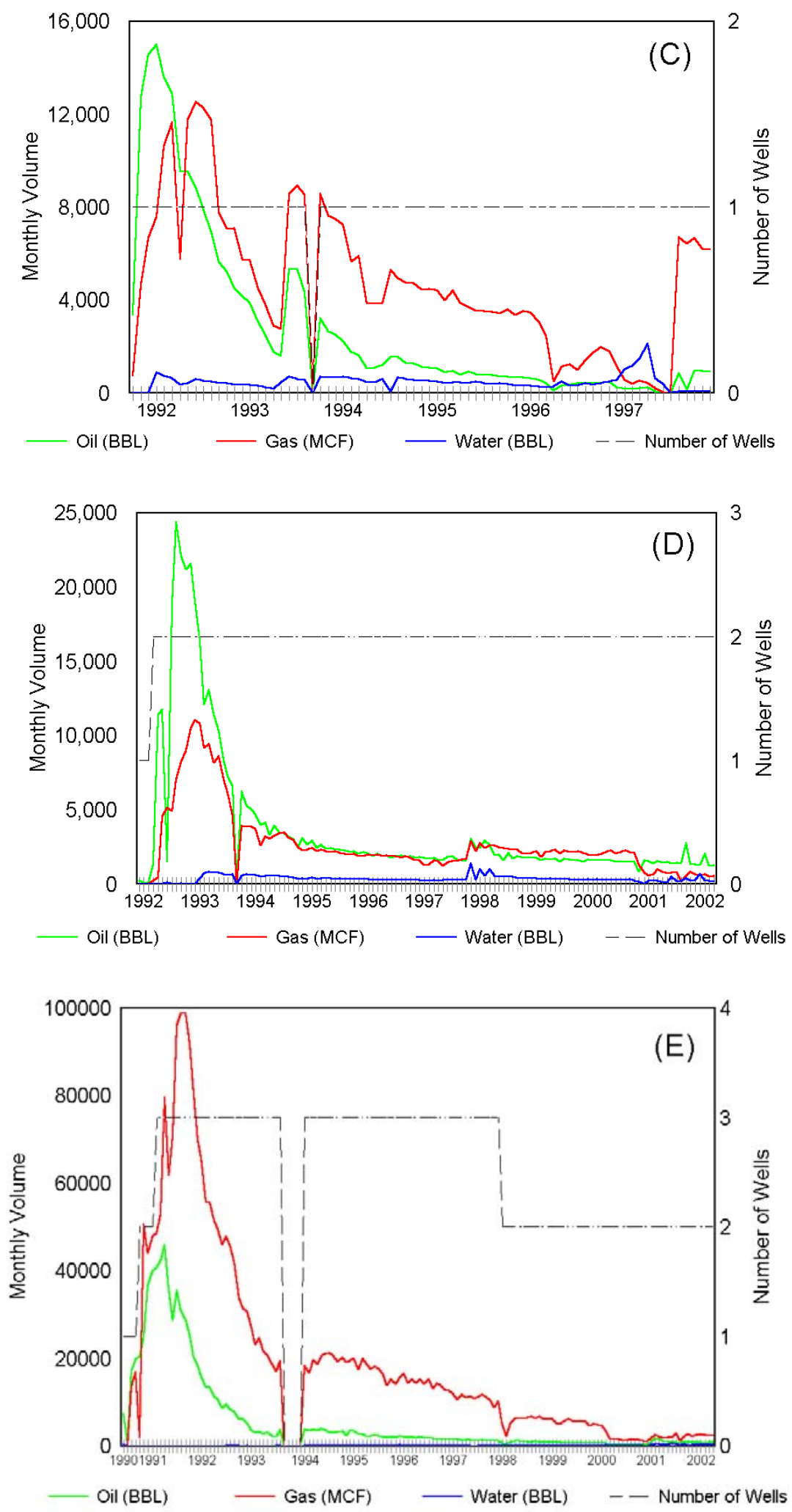

Figure 7-1 (continued) 


\section{Well Test Data Re-Evaluation}

Well-test data can provide key insight into the nature of reservoir heterogeneities, and also provide "large scale" quantitative data on actual reservoir properties such as storage and transmissibilities. Because of the complex geologic nature of Paradox Basin target reservoirs, a re-evaluation of past transient well tests was done to determine if the test data were adequate to provide a quantitative assessment of the two, key, oil-producing facies (supra-mound and mound-core intervals [referred to in this and the next section as dolomite and limestone respectively]) from case-study reservoirs. Although a number of well tests have been conducted in all of the target reservoirs, only the initial well tests, which were conducted under liquid saturated conditions (above bubble point) were determined to provide quantitative reservoir property information. A list of well tests re-evaluated in detail include:

\section{Reservoir Well}

Brown Hogan No. 1A-2

Blue Hogan No. 1J-1

Mule No. 31-M

Sahgzie No. 1

Sahgzie No. 1

Anasazi No. 1

Anasazi No. 1

Anasazi No. 1

Anasazi No. 1

\section{Test Date}

April 1991

February 1991

March 1992

July 1991

November 1989

January 1990

February 1990

January 1992

August 1993

To facilitate subsequent discussion, the following dual-property (porosity), well-test parameters for the model type employed in the analysis are summarized below.

Dual-porosity model:

Eq. 1

$$
\omega=\frac{\left(\phi c_{t} h\right)_{f}}{\left(\phi c_{t} h\right)_{f}+\left(\phi c_{t} h\right)_{m}}
$$

Eq. 2

$$
\lambda=\alpha r_{w}^{2} \frac{k_{m}}{k_{f}}
$$

Eq. 3

$$
\omega_{1}+\omega_{2}=1.0
$$

Eq. 4

$$
\alpha=12 / h^{2} \text { slab }
$$

Eq. 5

$$
\alpha=15 r_{s}^{2} \text { spherical }
$$

Eq. 6

$$
c_{t}=s_{w} c_{w}+s_{o} c_{o}+(1-\phi) c_{r}
$$


Fluid exchange between matrix and fracture:

- $\quad$ pseudo steady state

$$
k_{f}>100 k_{m}
$$

- $\quad$ one-dimensional transient

- $\quad$ three-dimensional transient

$$
\} \quad k_{f}>10 k_{m}
$$

Two-layer model:

Eq. 7

$$
\omega=\frac{\left(\phi c_{t} h\right)_{1}}{\left(\phi c_{t} h\right)_{1}+\left(\phi c_{t} h\right)_{2}}
$$

Eq. 8

$$
\lambda=\frac{2_{w}^{r} k_{v}}{\left[(k h)_{1}+(k h)_{2}\right]\left[h_{1}+h_{2}\right]}
$$

Eq. 9

$$
\omega_{1}+\omega_{2}=1.0
$$

Variables used in the above equations are defined as:

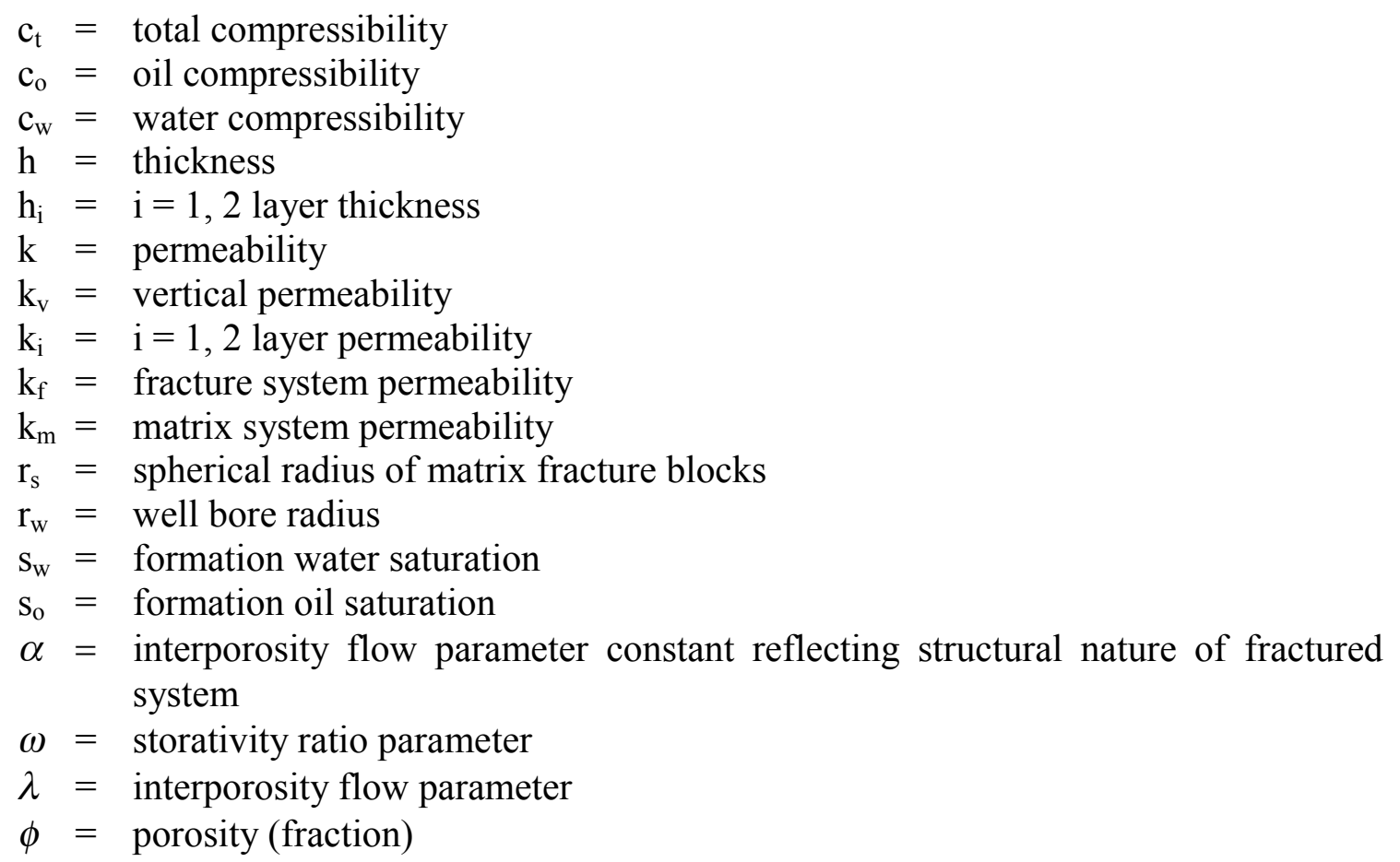

The parameter " $\omega$ " is simply the ratio of storage $\left(\phi c_{t} h\right)$ in one porosity unit to the total storage. The parameter " $\lambda$ " provides a measure of interporosity flow or fluid communication as governed by the absolute permeability thickness product (or effective permeability thickness) of the porous and permeable units in the model. 
The geologic review of the producing formation was used to establish basic guidelines in selecting the dual-property model. This model is different from the classical definition for dual-porosity and layered systems. The conventional definition for a dual-porosity/dualpermeability system is based on one dominant rock type or facies that exhibits a characteristic primary (or matrix) porosity and permeability. This single rock type is also fractured. Thus, a secondary (fracture) porosity and permeability system is present which is substantially different than the primary system. In the case of the Desert Creek zone, two dominant lithofacies are present (supra-mound dolomite and mound-core algal bafflestone [limestone]). These two lithofacies represent, in a generic sense, a dual-property system. Each rock type represents a single layer in a two-layer model; one layer represents the limestone and the other the dolomite, each with their own characteristic reservoir properties. In reality the limestone layer is comprised of a number of interconnected limestone units "sampled" by the well test and the dolomite layer represents the composite behavior of possibly several interconnected dolomite units. The observed well test response is governed by the interaction of the limestone facies with the dolomite facies. This type of response is consistent with data available in Bourdet (1985), which shows that behavior of multi-layer systems or heterogeneous systems, characterized by high contrasts in rock properties among layers or units of the heterogeneous system, can be modeled by using two elements (that is two layers). Multi-layer systems or heterogeneous systems with two dominant sets of properties behave like conventional two-layer systems with cross flow between layers (or units).

Unfortunately, of all the tests analyzed, only one provided enough detailed information to allow a meaningful "dual-porosity" interpretation. The purpose of all early well tests was to provide information on production performance and perhaps skin factors, so insufficient data was gathered for quantitative dual-porosity interpretations. Pressure data in early well tests was measured infrequently, and the duration of most tests was too short. The single test that could be quantitatively analyzed with a "dual-porosity" model was the Anasazi No. 1, January 1990 test.

Figures 7-2 to 7-4 present the match between measured data ( + symbol) and well test interpretation results (solid line) using a two-layer model with cross flow employing the parameters listed on each figure. A good match was obtained and indicates that the main limestone producing unit (mound-core interval) can be characterized as having a permeability of $194 \mathrm{md}$ and the dolomite (supra-mound interval) a much lower permeability of $1.21 \mathrm{md}$. The storativity ratio " $\omega$ " indicates that roughly 3.5 percent of the storage of the combined system is contained in the limestone unit. This two-layer approach, with a similar range of properties, was employed in mechanistic simulation studies (discussed later in Chapter 8, Mechanistic Reservoir Simulation Studies) and supports this well test interpretation.

All well tests conducted on Runway wells have been analyzed using contemporary well test analysis technology. In general, each interval test from all three Runway wells behaved like a homogeneous system utilizing either fully penetrating and/or partial penetrating well models. The one exception was the zone 4 test from the Runway No. 10C-5A well. This required the use of a two-layer model to match observed data. Figures 7-5 and 7-6 illustrate the excellent agreement between field data and model predictions for the zone 2 test from the Runway No. 10-E-2 well. Reservoir parameters used for the model are shown on the figures. All other tests had similar quality matches. 


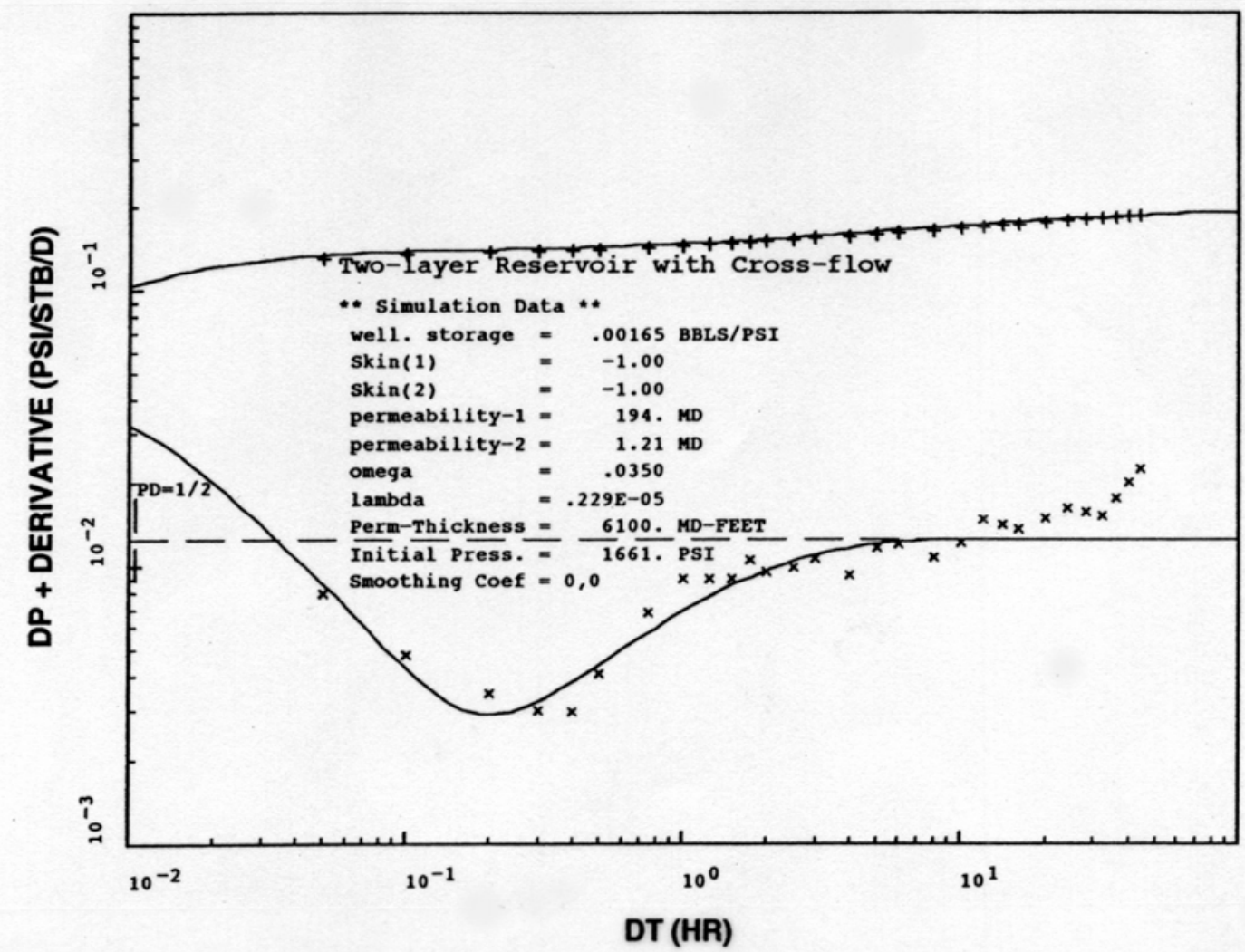

Figure 7-2. Anasazi No. 1 well test (1991) displaying pressure difference and pressure derivative match.

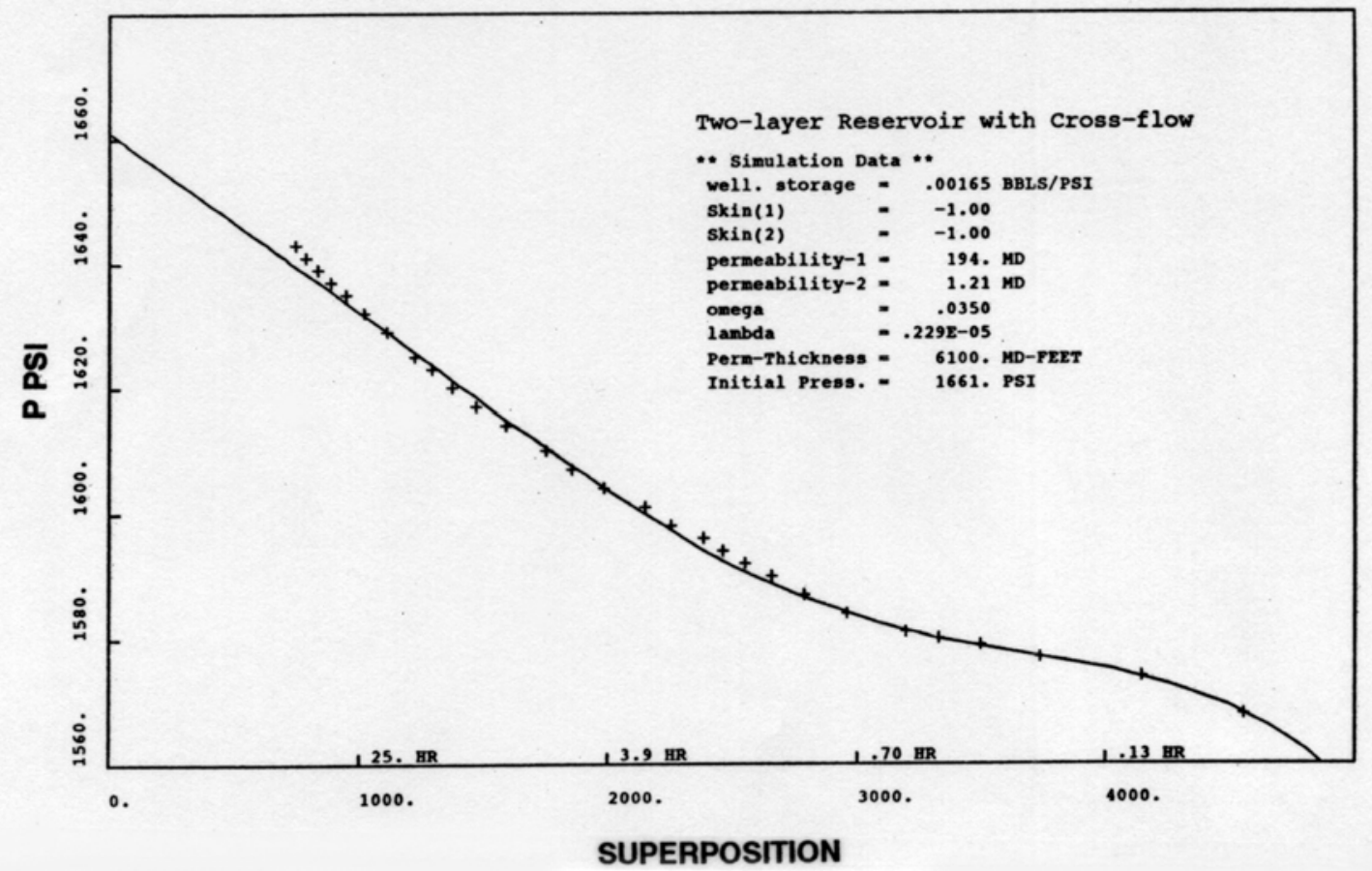

Figure 7-3. Anasazi No. 1 well test (1991) displaying superposition time vs. pressure match. 

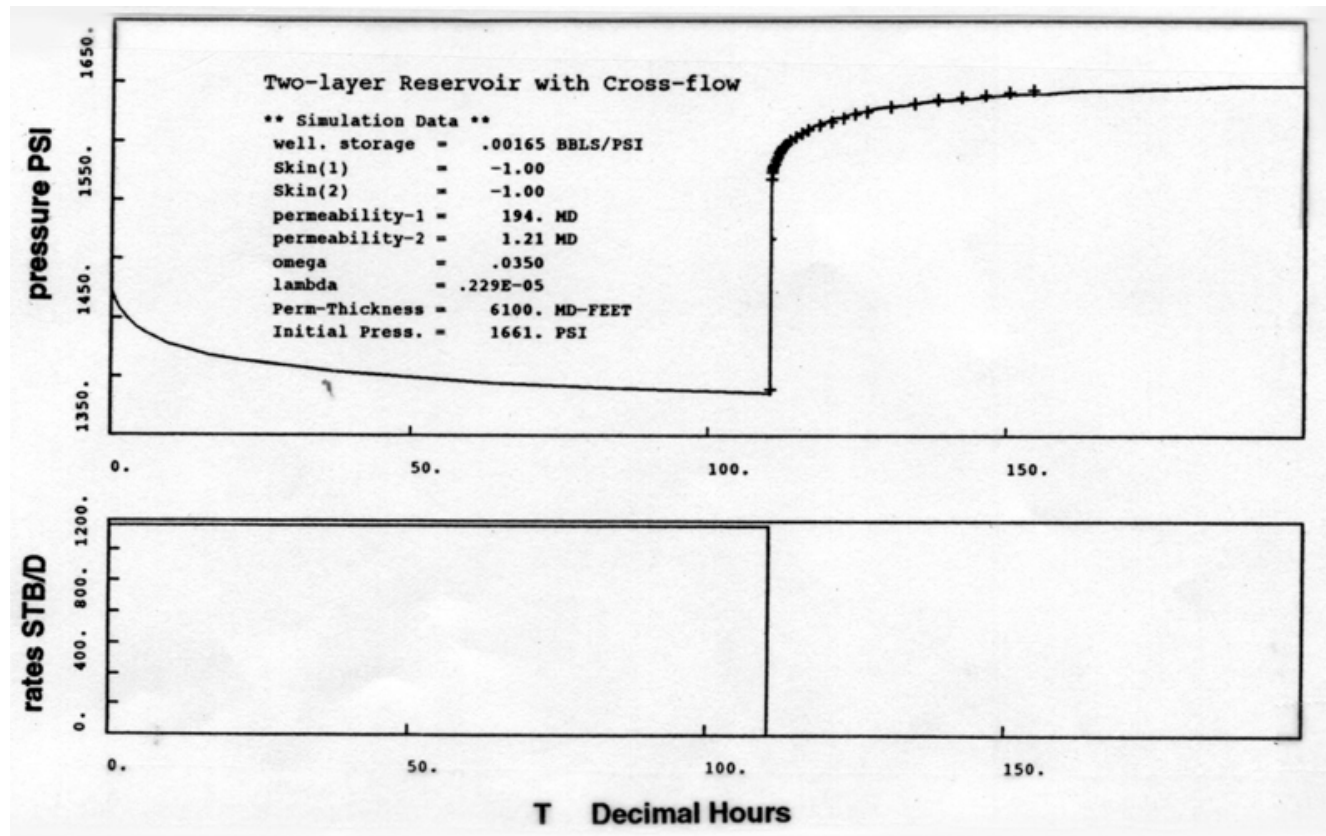

Figure 7-4. Anasazi No. 1 well test (1991) displaying pressure vs. time match.

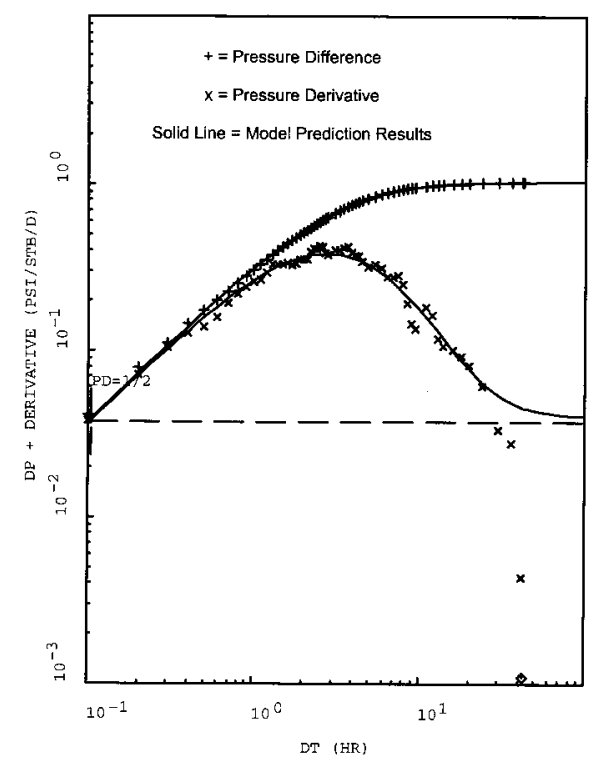

Partial Penetration Well

* * Simulation Data **

well. storage $=154 \mathrm{BBLS} / \mathrm{PS}$

$\operatorname{skin}($ perf.) $=.750$

Dermeability $=32.0 \mathrm{MD}$

$=.0500$

EfE. Thickness $=30.0 \mathrm{FEET}$

$\mathrm{Zp} /$ Heff $\quad=.410$

Perm-rimickness $=960$. MD-PEET

Initial press $=2013 . \mathrm{BaI}$

Smoothing coes $=0.0$. Bar

Figure 7-5. Runway No. 10-E-2 well, zone 2 test pressure derivative and pressure difference match, Runway field. 


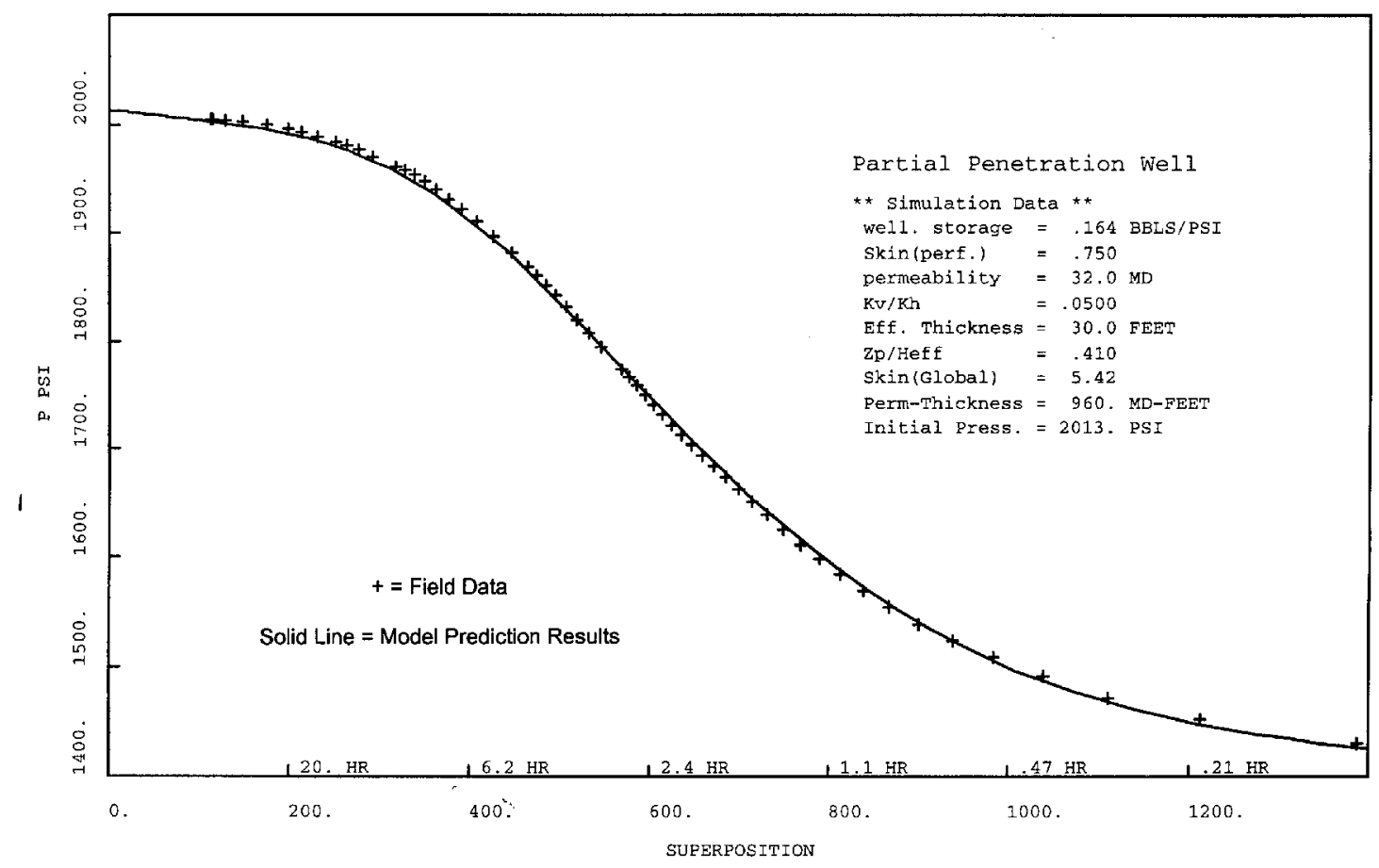

Figure 7-6. Runway No. 10-E-2 well, zone 2 test superposition plot match, Runway field.

\section{Fluid Characterization}

Two recovery processes were evaluated to determine which has the greater recovery potential. The first was the waterflood, which used fluid properties suitable for black oil reservoir studies. The second recovery process was $\mathrm{CO}_{2}$ gas injection. Since $\mathrm{CO}_{2}$ processes require compositional based data, more comprehensive fluid property data was needed. As discussed above, a compositional approach was taken, even in the black oil cases. Existing black oil data, however, was used to help in equation of state calibration activities. Review of existing PVT studies indicated an inadequate data set for compositional simulation and $\mathrm{CO}_{2}$ process evaluation. Thus, the following laboratory work, described below, was carried out. Assessment of the $\mathrm{CO}_{2}$ process required calibration of an equation of state using the following laboratory work for tuning. The laboratory work included:

1. extended (plus 30 carbon molecule $[\mathrm{C} 30+]$ ) compositional analysis on a recombined fluid sample,

2. a two-stage separator test, including a stock-tank condition, and

3. swelling tests employing four concentrations of $\mathrm{CO}_{2}$ with measurements of twophase relative volumes at eight pressures for each mixture. Saturated liquid density and viscosity measurements for each mixture. Swelling tests used four discrete additions of injection gas $\mathrm{CO}_{2}$ that is added to the recombined reservoir oil. 
A discussion and presentation of the results of the fluid composition work (extracted from D.B. Robinson Research Ltd. (1995) follows.

\section{Sample Preparation and Compositional Analysis}

The following Anasazi fluid samples were taken for study purposes:

- $\quad$ three separator oil cylinders (1 gal [3.8 L] each) labeled Anasazi 5L-3 field, cylinder nos. W4635, W8301, and W3A8302,

- $\quad$ three separator gas cylinders (one $500 \mathrm{~cm}^{3}$ and two $300 \mathrm{~cm}^{3}$ ) labeled Anasazi $5 \mathrm{~L}-3$ field, and

- $\quad$ three dead oil containers (1 gal [3.8 L] each) labeled as follows:

- Anasazi 5L-3

- $\quad$ Anasazi $6 \mathrm{H}-1$ limestone perforation (5,723 to 5,730 feet [1,744-1,746 m])

- Anasazi 6H-1 dolomite perforation (5,680 to 5,694 feet [1,731-1,735 m]).

Note that one of the three separator oil cylinders, namely W3A8302, was not properly filled during transferring; thereby, the corresponding fluid was not analyzed. Compositional analyses were conducted on separator oils, separator gases, and dead oils.

Separator oils: The separator oils were initially equilibrated at 1,000 pounds per square inch gauge (psig $[6,895 \mathrm{kpa}])$ and $73^{\circ} \mathrm{F}\left(23^{\circ} \mathrm{C}\right)$ (that is at single phase conditions). The separator conditions for these samples were reported to be $35 \mathrm{psig}(241 \mathrm{kpa})$ and $85^{\circ} \mathrm{F}\left(29^{\circ} \mathrm{C}\right)$. Next, samples of the separator oils were analyzed for their $\mathrm{C} 30+$ composition by the flash procedure. Accordingly, an accurately measured volume of each fluid was isobarically $(1,000 \mathrm{psig})$ displaced into a pycnometer where its density and mass were evaluated. The pycnometer was then connected to a gas-oil ratio (GOR) single-stage flash apparatus where the fluid was flashed to ambient pressure and temperature conditions. Subsequently, the evolved gas phase was circulated through the residual liquid for a period of time to achieve equilibrium between phases. Following circulation, the volume of equilibrium vapor and the mass of liquid remaining in the pycnometer were measured. The vapor phase was resolved to $\mathrm{C} 5$ by gas chromatography $(\mathrm{GC})$ while the vapor $\mathrm{C} 5+$ fraction and the residual liquids were analyzed to $\mathrm{C} 30+$ also with the GC. From the measured composition and total mass of each phase, the composition of the original live fluid was calculated by a mass balance (the $\mathrm{C} 30+$ compositions of the two separator oils analyzed are listed in tables B.1 and B.2, Appendix B, Chidsey, 1997). Both separator oil samples are fairly representative of one another for they have similar compositions, densities, and GORs.

Separator gases: Separator gases from the $300 \mathrm{~cm}^{3}$ cylinders (cylinder nos. 5EK088 and 6EK087) were analyzed for composition using GC analysis (the results are listed in tables B.3 and B.4, Appendix B, Chidsey, 1997). Both gases have essentially the same compositions within accepted GC precision. 
Dead oil: The dead oil samples received were heated in their respective containers to $120^{\circ} \mathrm{F}$ $\left(49^{\circ} \mathrm{C}\right)$ and then agitated to homogenize them. Thereafter, a hot sample of each dead oil was dissolved in carbon disulfide and analyzed for composition using liquid GC analysis. The measured $\mathrm{C} 30+$ liquid compositions are plotted in figure 7-7 (and presented in table B.5, Appendix B, Chidsey, 1997 [for ease of comparison, the corresponding results for the flashed separator oils are also included in this same table]).

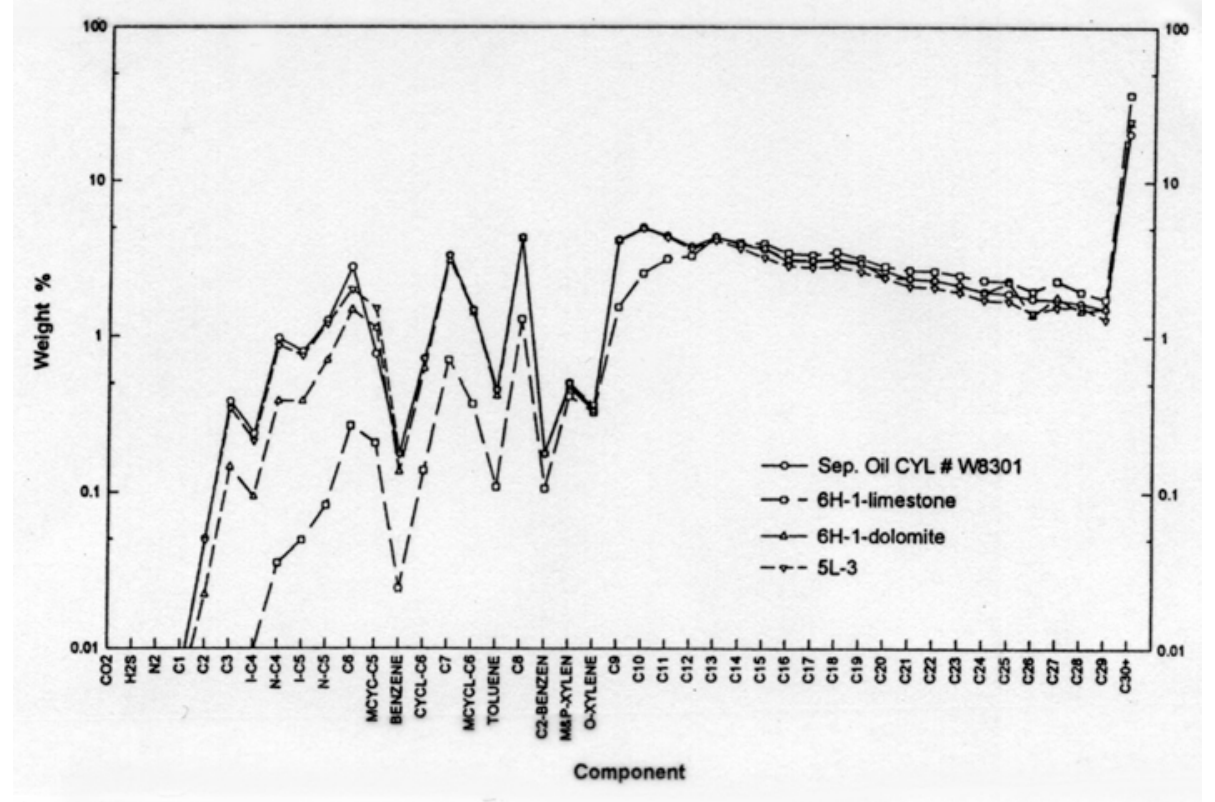

Figure 7-7. Comparison of the (C30+) weight-percent composition measured for the flashed separator oil (cylinder W8301) and dead oil samples (6H-1-limestone, 6H-1-dolomite, and 5L-3).

Before discussing these results, it is important to note that only the Anaaszi No. 5L-3 well dead oil was flashed/collected directly from the separator. Both the Anasazi No. $6 \mathrm{H}-1$ well dolomite and the Anasazi No. 6H-1 well limestone samples were collected during swab test operations and stored on site and thus, because of the nature of the containers, were subject to light end losses.

The dead oils have relatively higher $\mathrm{C} 30+$ fractions than the corresponding dead oils flashed from the separator oils (cylinder nos. W4635 and W8301). More importantly, the Anasazi No. 6H-1 well limestone dead oil is observed to differ significantly in composition from the rest of the oil samples. The thermal histories, of the limestone and dolomite samples caused most of the light ends to evaporate.

\section{Fluid Recombination and Swelling Tests}

Fluid recombination: Separator oil and gas samples (synthetic) were recombined at a separator GOR of 1,208 standard cubic feet per stock tank barrel (scf $/$ STB $\left[242 \mathrm{~m}^{3}\right.$ of gas $/ \mathrm{m}^{3}$ of oil]). Details of the recombination are available in D.B. Robinson Research Ltd. (1995). The composition of the recombined sample is presented in Chidsey, 1997, Appendix B, table B.6. 
Swelling tests: Preliminary simulation studies of the Anasazi field indicated that if the field was re-pressured the existing free gas phase would be forced into solution in the oil and the remaining liquid would exhibit a bubble point of approximately 2,050 pounds per square in absolute (psia [14,135 kpa]). This was selected as a reasonable starting point, from a fluid compositional standpoint, for $\mathrm{CO}_{2}$ swelling tests for future equation-of-state calibration work. Thus, the recombined fluid (see table B.6, Appendix B in Chidsey, 1997) was used to prepare a fluid sample exhibiting a 2,050 psia $(14,135 \mathrm{kpa})$ bubble point at a reservoir temperature of $130^{\circ} \mathrm{F}\left(54^{\circ} \mathrm{C}\right)$. Details of the sample preparation are contained in D.B. Robinson Research Ltd. (1995). The composition of this mixture is presented in Chidsey, 1997, Appendix B, table B.7.

Using the reservoir fluid with a bubble point of 2,050 psia $(14,135 \mathrm{kpa})$, swelling tests employing 20, 40, 60, and 75 mole percent $\mathrm{CO}_{2}$ were conducted. Laboratory measurements consisted of determining a number of pressure-volume (PV) data points for each mixture and also measuring the density and viscosity of each saturated liquid mixture. A sufficient number of PV measurements in the single phase and two phase region were made for each mixture to allow determination of the bubble point or dew point of each mixture. Results of these tests are presented in Chidsey, 1997, Appendix C, tables C.1 through C.10. A summary of the swelling tests is presented in table 7-3.

Table 7-3. Swelling test data for the Anasazi No. $5 \mathrm{~L}-3$ oil at $130^{\circ} \mathrm{F}\left(54^{\circ} \mathrm{C}\right)$.

\begin{tabular}{|c|c|c|c|c|c|c|c|}
\hline \multirow{2}{*}{$\begin{array}{c}\mathrm{CO}_{2} \\
\text { Concentration } \\
(\mathrm{Mole} \%)\end{array}$} & \multicolumn{2}{|c|}{$\begin{array}{c}\text { Saturation Pressure } \\
\text { (psia) }\end{array}$} & \multirow{2}{*}{$\begin{array}{l}\text { Vsat } \\
\left(\mathrm{cm}^{3}\right)\end{array}$} & \multirow{2}{*}{$\begin{array}{l}\text { Bulk } \\
\text { Density } \\
\left(\mathrm{g} / \mathrm{cm}^{3}\right)\end{array}$} & \multirow{2}{*}{$\begin{array}{l}\text { Molar Volume } \\
\left(\mathrm{cm}^{3} / \mathrm{mol}\right)\end{array}$} & \multirow{2}{*}{$\begin{array}{l}\text { Swelling } \\
\text { Factor** } \\
\left(\mathrm{cm}^{3} / \mathrm{cm}^{3}\right)\end{array}$} & \multirow[t]{2}{*}{ (cP) } \\
\hline & Measured & Predicted $^{*}$ & & & & & \\
\hline 00.0 & $2,050 \dagger$ & 2,050 & 59.61 & 0.664 & 129.12 & 1.000 & \begin{tabular}{|l|}
0.464 \\
\end{tabular} \\
\hline 20.0 & $2,294 \dagger$ & 2,254 & 65.83 & 0.678 & 114.14 & 1.104 & 0.349 \\
\hline 40.0 & $2,585 \dagger$ & \begin{tabular}{|l|}
2,586 \\
\end{tabular} & 72.45 & 0.697 & 99.63 & 1.215 & \begin{tabular}{|l|}
0.270 \\
\end{tabular} \\
\hline 60.0 & $3,176 \dagger$ & \begin{tabular}{|l}
3,729 \\
\end{tabular} & 73.55 & 0.725 & 83.72 & 1.234 & \begin{tabular}{|l|}
0.215 \\
\end{tabular} \\
\hline 75.0 & $5,800 \ddagger$ & & 78.20 & 0.805 & 67.63 & 1.312 & 0.210 \\
\hline
\end{tabular}

† Graphically

$\ddagger$ Visually

* Predicted by Robinson's EQUI-90

** Swelling Factor $=\mathrm{V}_{\text {sat }}$ (of $\mathrm{CO}_{2}+$ oil mixture) $/ \mathrm{V}_{\text {sat }}$ (virgin oil)

where $\mathrm{V}_{\text {sat }}($ virgin oil $)=59.61 \mathrm{~cm}^{3}$

\section{Separator Tests}

A two-stage separator test was conducted. The first stage involved flashing recombined fluid at 3,014 psia and $70^{\circ} \mathrm{F}\left(20,782 \mathrm{kpa}\right.$ and $\left.21^{\circ} \mathrm{C}\right)$ to $35 \mathrm{psia}$ and $85^{\circ} \mathrm{F}\left(241 \mathrm{kpa}\right.$ and $\left.2^{\circ} \mathrm{C}\right)$. The second stage involved a flash to 0.0 psig and $60^{\circ} \mathrm{F}\left(16^{\circ} \mathrm{C}\right)$. Separator data are presented in tables 7-4 and 7-5 (the gas compositional data are presented in table B.8, Appendix B, Chidsey, 1997). 
Table 7-4. Separator test volumetric data.

Initial volume $=31.00 \mathrm{~cm}^{3}$ at $3,014 \mathrm{psia}(20,782 \mathrm{kpa})$ and $70^{\circ} \mathrm{F}\left(21^{\circ} \mathrm{C}\right)$

1st Stage Flash $35 \mathrm{psig}(241 \mathrm{kpa})$ and $85^{\circ} \mathrm{F}\left(29^{\circ} \mathrm{C}\right)$

\begin{tabular}{|l|l|l|l|}
\hline & \multicolumn{1}{|c|}{ Volume $\left(\mathbf{c m}^{3}\right)$} & \multicolumn{1}{c|}{ Density $\left(\mathbf{g} / \mathbf{c m}^{3}\right)$} & \multicolumn{1}{c|}{$\mathbf{M W} \mathbf{~ ( g / g m o l})^{*}$} \\
\hline Vapor & $1,248.16$ & 0.0037 & 26.19 \\
\hline Liquid & 19.72 & 0.7922 & \\
\hline
\end{tabular}

Initial volume $=24.97 \mathrm{~cm}^{3}$ at $35 \mathrm{psia}(241 \mathrm{kpa})$ and $85^{\circ} \mathrm{F}\left(29^{\circ} \mathrm{C}\right)$

2nd Stage Flash 0 psig $(0 \mathrm{kpa})$ and $60^{\circ} \mathrm{F}\left(16^{\circ} \mathrm{C}\right)$

\begin{tabular}{|c|l|l|l|c|}
\hline & \multicolumn{1}{|c|}{ Volume $\left(\mathbf{c m}^{3}\right)$} & Density $\left(\mathbf{g} / \mathbf{c m}^{3}\right)$ & Gravity $\left(\mathbf{A P I}{ }^{\circ}\right)$ & MW $(\mathbf{g} / \mathbf{g m o l})^{*}$ \\
\hline Vapor & 98.16 & 0.0014 & & 39.14 \\
\hline Liquid & 24.76 & 0.8103 & 43.13 & \\
\hline
\end{tabular}

${ }^{*} \mathrm{MW}=$ molecular weight

Table 7-5. Separator test-produced GOR.

\begin{tabular}{|c|l|l|}
\hline Stage & \multicolumn{2}{|c|}{ per stage } \\
& \multicolumn{1}{|c|}{ GOR (scf/STB) } \\
cumulative \\
\hline 1st Stage Flash & $1,197.4$ & $1,197.4$ \\
\hline 2nd Stage Flash & 20.4 & $1,217.8$ \\
\hline Total & $1,217.8$ & $1,217.8$ \\
\hline
\end{tabular}

\section{Summary}

Detailed compositional analysis, separator tests, and swelling tests involving four concentrations of $\mathrm{CO}_{2}$ were completed. Swelling factors exceeded 30 percent and oil viscosity was reduced by more than a factor of 2.0. This new fluid property data, in combination with existing basic black oil PVT data of the original reservoir fluid, provides the basis for calibrating or tuning an equation of state. The equation-of-state parameters were be used in the compositional reservoir simulation study to evaluate implementation of a $\mathrm{CO}_{2}$ flood in typical Paradox Basin reservoirs in the Desert Creek zone.

\section{Rock Characterization}

One of the key data sets required for reservoir recovery process evaluation via simulation is relative permeability data. Although an extensive core inventory exists for the Paradox Basin reservoirs in the Desert Creek zone, all cores are in an unpreserved state. With the drilling of the Anasazi No. 6H-1 well in 1995, an opportunity existed to obtain a fresh core and preserve the core. Preserved cores can be used to conduct wettability and relative permeability measurements employing various core preparation procedures. Analysis of the resulting data from these measurements can provide guidelines for core preparation in future relative permeability work and provide a valid data set for future reservoir simulation studies. Representative samples from the preserved Anasazi No. 6H-1 core were taken based on computerized axial tomography scans of the core, and used for a suite of capillary pressure, wettability, and relative permeability measurements. 
Since a representative Desert Creek limestone interval was not present in the Anasazi No. 6H-1 well, the tests were performed on samples from the dolomite interval. Once the proper core preparation procedures were identified, unpreserved core material from another Anasazi well could be used for future limestone relative permeability. In addition to the tests discussed above, samples from the Anasazi No. 6H-1 (dolomite) and Anasazi No. 1 (limestone) wells were used for rock compressibility measurements. Because an important part of the production life of the Paradox Basin reservoirs in the Desert Creek zone involved liquid expansion and no compressibility data existed, it was important to obtain representative data to use in reservoir performance modeling.

All these tests (except limestone relative permeability) results are summarized in the following sections, using extracted material from Westport Technology Center International (1995) and TerraTek, Inc. (1995) reports.

\section{Computerized Axial Tomography}

Whole core intervals were scanned using computerized axial tomography (CAT) techniques to ensure that permeability measurements are based on comparable pore systems. The three most homogeneous intervals were selected for additional analysis. Upon further examination and CAT scans, one interval $(5,691$ feet $[1,735 \mathrm{~m}])$ appeared as the most homogeneous and contained the highest porosity. Four transverse plugs were taken from this interval for detailed CAT scans, and porosity and relative permeability measurements (figure 78). A variety of features were observed using these techniques including anhydrite-filled vugs, both micro-vuggy and intercrystalline porosity, patches of bitumen-filled pores, and areas of nonporous carbonate mudstone.

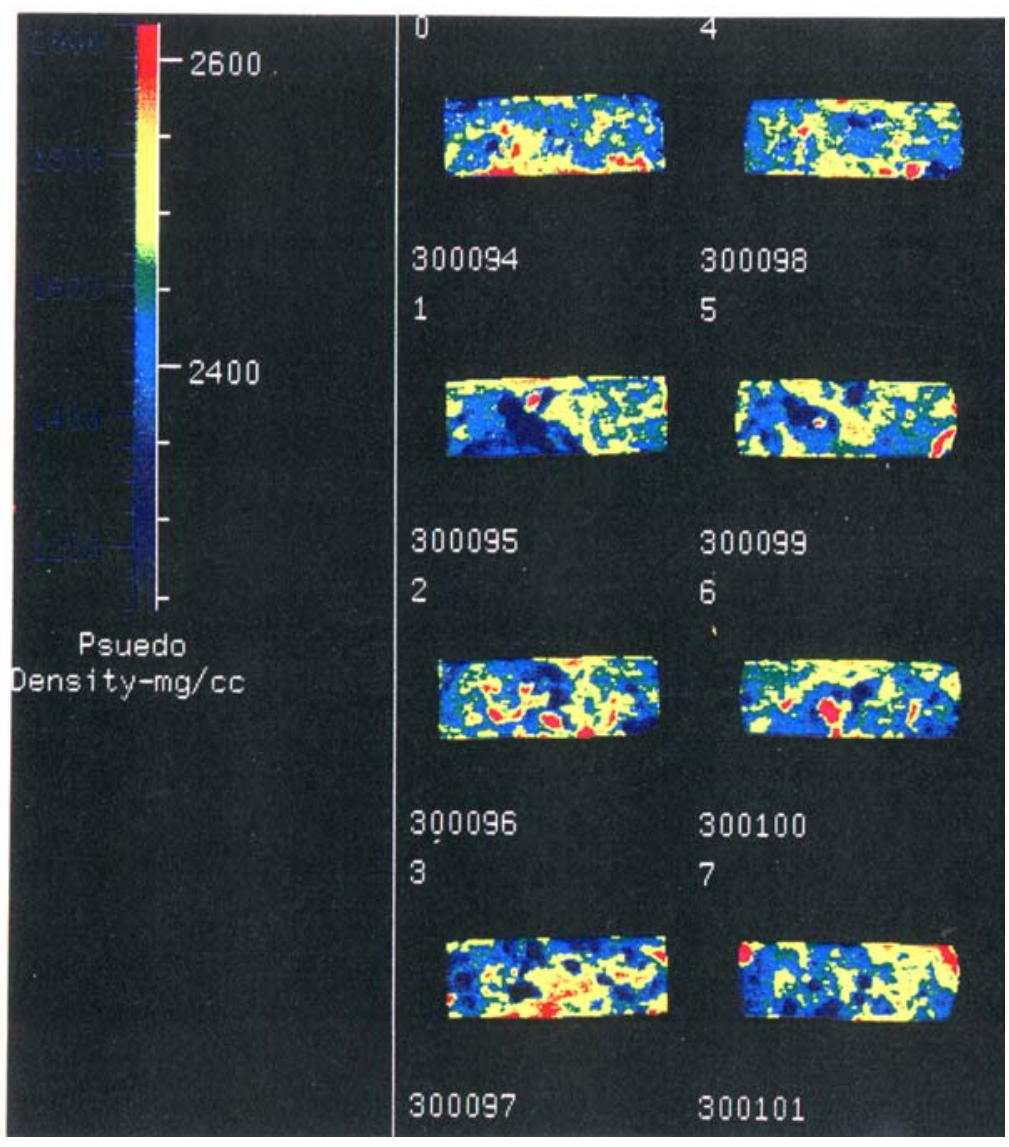

Figure 7-8. A set of CAT scans of two mutually perpendicular longitudinalaxial sections of each of the four core plugs taken from the Anasazi No. 6H-1 well to assess heterogeneity and select the most consistent intervals for measuring porosity and relative permeability in the Anasazi reservoir. The relative shades indicate pseudo density ( $\mathrm{mg} / \mathrm{cc})$; the reference numbers pertain to the CAT scan locations on the core. 


\section{Relative Permeability Measurements}

Relative permeability work consisted of determining oil-brine and gas-oil capillary pressure data employing ultra centrifuge technology. These tests were conducted at reservoir temperature $\left(130^{\circ} \mathrm{F}\left[54^{\circ} \mathrm{C}\right]\right)$. Ultra centrifuge data were used to determine core-plug wettability and relative permeability values. In Runway field, these data were used to determine relative permeability data for the bryozoan bindstone/framestone facies.

Restored-state core plugs were used for the experimental study. The data indicate a mixed wettability condition with a slightly stronger water-wetting tendency than previously found for the supra-mound interval (upper part of the carbonate buildup) samples from the Anasazi No. 6H-1 well. An oil/gas imbibition experiment provided data on the value of the trapped gas saturation. A value of 11.2 percent was determined from the experiment.

Capillary pressure data generation, using high-pressure mercury injection $(>50,000$ pounds per square inch [psi]) was completed on the end pieces of the core samples used to develop relative permeability data for the dolomite and limestone productive facies from the Anasazi reservoir. The tests were conducted to compare reservoir properties of samples used for the relative permeability measurements to previously measured properties on core from the Anasazi No. 5L-3 well. Capillary pressure and pore-size-distribution data of samples from the Anasazi Nos. 1 and 6H-1 wells were comparable to similar measurements taken on core samples from the Anasazi No. 5L-1 well. Pore-size distribution plots are shown in figure 7-9.

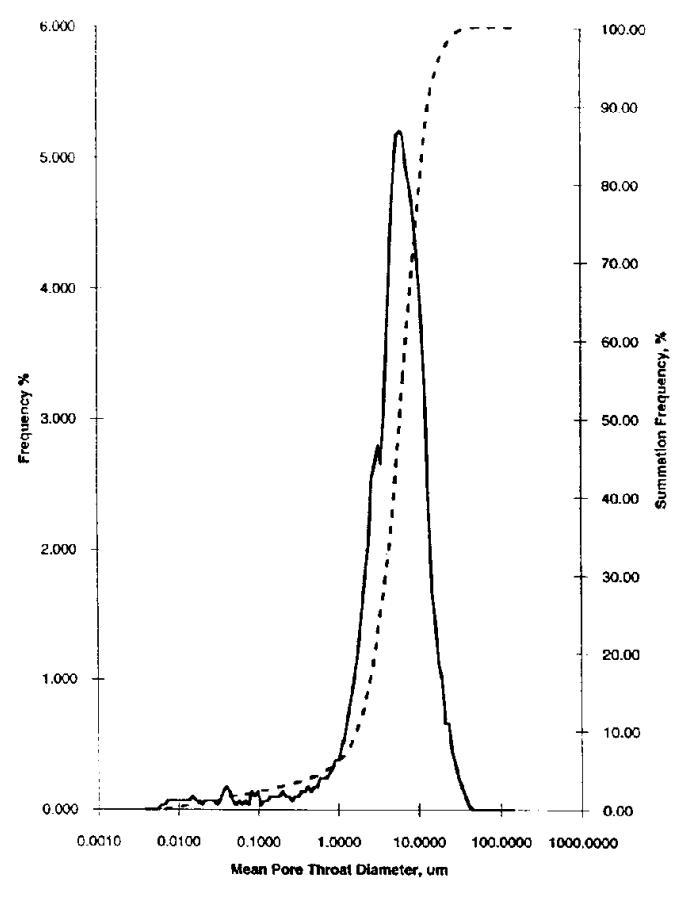

(A)

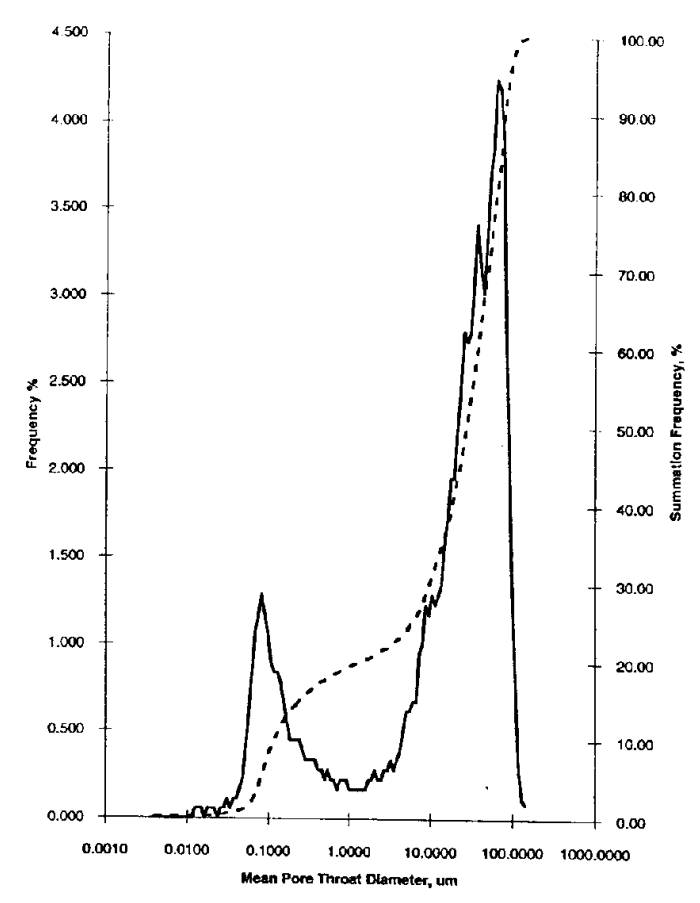

(B)

Figure 7-9. Pore-size distribution plots for Anasazi field. (A) Supra-mound interval (dolomite) facies, Anasazi No. 6H-1 well. (B) Mound-core interval (limestone) facies, Anasazi No. 1 well. 
Fluid measurements: The brine used in these experiments was a synthetic formation brine. The water analysis was for a sample collected on July 28, 1995 from the Sahgzie No. 1 well separator. The sample was filtered through a 0.45 micron filter (see table $7-6$ ) after mixing. The original brine was a saturated solution at ambient temperatures and was diluted to 3/4 strength to prevent salt precipitation during the temperature cycling the samples were subjected to in the course of the testing.

Table 7-6. Brine composition.

\begin{tabular}{|l|l|}
\hline \multicolumn{1}{|c|}{ Brine } & \multicolumn{1}{|c|}{ Wt \% } \\
\hline Sodium Chloride $(\mathrm{NaCl})$ & 9.10 \\
\hline Calcium Chloride $\left(\mathrm{CaCl}_{2} .2 \mathrm{H}_{2} \mathrm{O}\right)$ & 6.00 \\
\hline Magnesium Chloride $\left(\mathrm{MgCl}_{2} .6 \mathrm{H}_{2} \mathrm{O}\right)$ & 2.00 \\
\hline Potassium Chloride $(\mathrm{KCl})$ & 0.23 \\
\hline
\end{tabular}

The crude oil was obtained from the surface separator for Anasazi No. 5L-3 well in August 1995 and used after filtering through a 0.45 micron filter at $73^{\circ} \mathrm{F}\left(23^{\circ} \mathrm{C}\right)$. Fluid properties were measured from $73^{\circ} \mathrm{F}$ to $135^{\circ} \mathrm{F}\left(23-57^{\circ} \mathrm{C}\right)$ since fluid saturations had to be measured at ambient conditions and the experiments conducted at $130^{\circ} \mathrm{F}\left(54^{\circ} \mathrm{C}\right)$. Data are provided for the oil properties in table 7-7. The surface and interfacial tension measurements were made using a ring pull tensiometer and thus, are nonequilibrium measurements.

Table 7-7. Fluid properties.

\begin{tabular}{|c|l|l|l|l|l|}
\hline Fluid & \multicolumn{1}{|c|}{ Temp $\left({ }^{\circ} \mathbf{F}\right)$} & Density $\left(\mathbf{g} / \mathbf{c m}^{3}\right)$ & Viscosity (cP) & $\begin{array}{c}\text { Interfacial Tension } \\
\text { (dynes/cm) }\end{array}$ & $\begin{array}{c}\text { Surface Tension } \\
\text { (dynes/cm) }\end{array}$ \\
\hline Brine & 75.000 & 1.1930 & 1.975 & 17.200 & \\
\hline Brine & 130.000 & 1.1791 & 1.005 & 15.600 & \\
\hline Crude Oil & 75.000 & 0.8229 & 4.730 & & 26.800 \\
\hline Crude Oil & 130.000 & 0.8014 & 2.580 & & 25.500 \\
\hline
\end{tabular}

Experimental procedures: Collected data were analyzed using techniques by Hirasaki and others (1990). The capillary pressure data were analyzed using a constrained Hassler-Brunner modeling technique. The relative permeability experiment was an unsteady state displacement in which only the displaced phase permeability can be analyzed. The data were corrected for capillary hold-up, invading phase mobility, and speed ramp-up effects then fitted to a bimodal Corey model to account for mobility shock production.

Resaturation and $\mathbf{K}_{\text {ew }}$ measurements: Because of the saturated condition of the reservoir brine, all samples were flushed with the lower salinity brine in an attempt to remove any precipitated salts from the materials. Samples 1a, 1b, 2, and $4 \mathrm{a}$ had "as received" flowing permeabilities measured using this brine. Core 2 was then cleaned using a sequential, solvent, flow-cleaning procedure and cut into samples $2 \mathrm{a}$ and $2 \mathrm{~b}$. Core $1 \mathrm{a}$ was then flow cleaned using the same solvent-cleaning technique. Cores $1 \mathrm{a}$ and $2 \mathrm{~b}$ were then brine saturated under 500 psi $(3,448 \mathrm{kpa})$ back pressure and effective water permeability $\left(\mathrm{K}_{\mathrm{ew}}\right)$ values measured at 100 percent brine saturation. 
Initial oil/brine drainage experiment and aging: An initial oil/brine drainage capillary pressure experiment was conducted on cores $1 \mathrm{~b}$ and $2 \mathrm{~b}$ to establish a high initial oil saturation for the aging process. Aging was accomplished for 14 days at $130^{\circ} \mathrm{F}\left(54^{\circ} \mathrm{C}\right)$. Near the end of the aging process, an oil/brine drainage capillary pressure experiment was conducted on core 1a to establish a high initial oil saturation without the aging of the other cores.

Brine/oil imbibition capillary pressure test: Initial flowing oil permeabilities were measured and then an imbibition capillary pressure experiment was conducted for use in wettability determination. A comparison of the data is given in figure 7-10. The curve shapes indicate an oil wetting condition since the oil saturation continues to decrease with increased capillary pressure until a value below 5 percent remaining oil is achieved near 100 psi (690 kpa). Comparisons of the core entry values using the Leverett " $\mathrm{J}$ " function seen in figure 7-10B indicate a slightly stronger oil wetting condition in the preserved and restored cores over the cleaned but unrestored core.

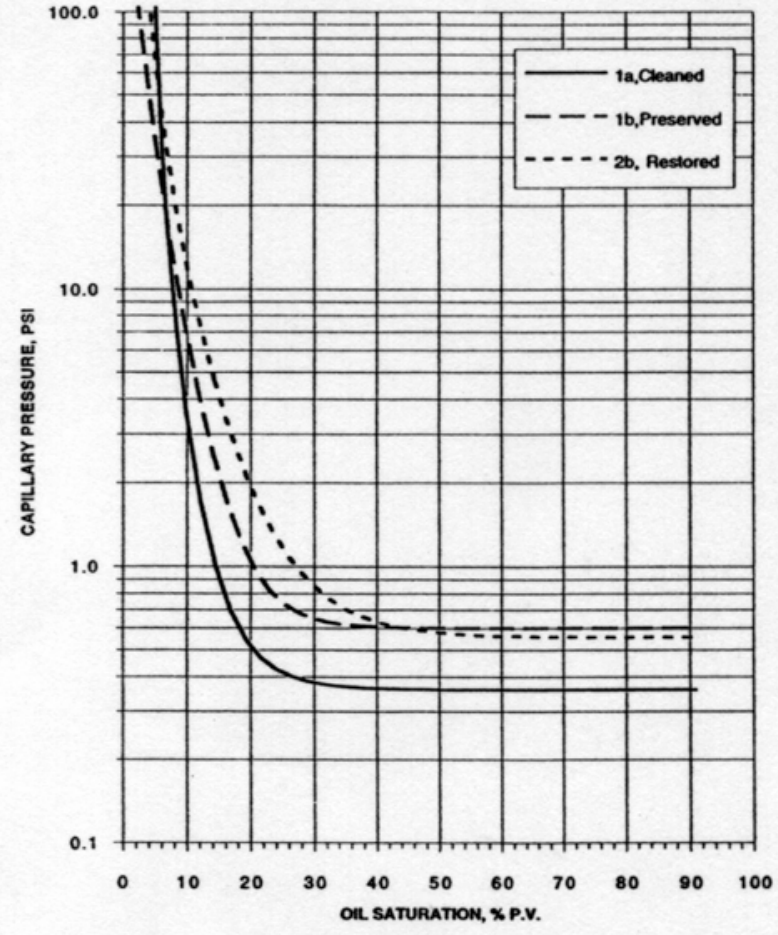

(A)

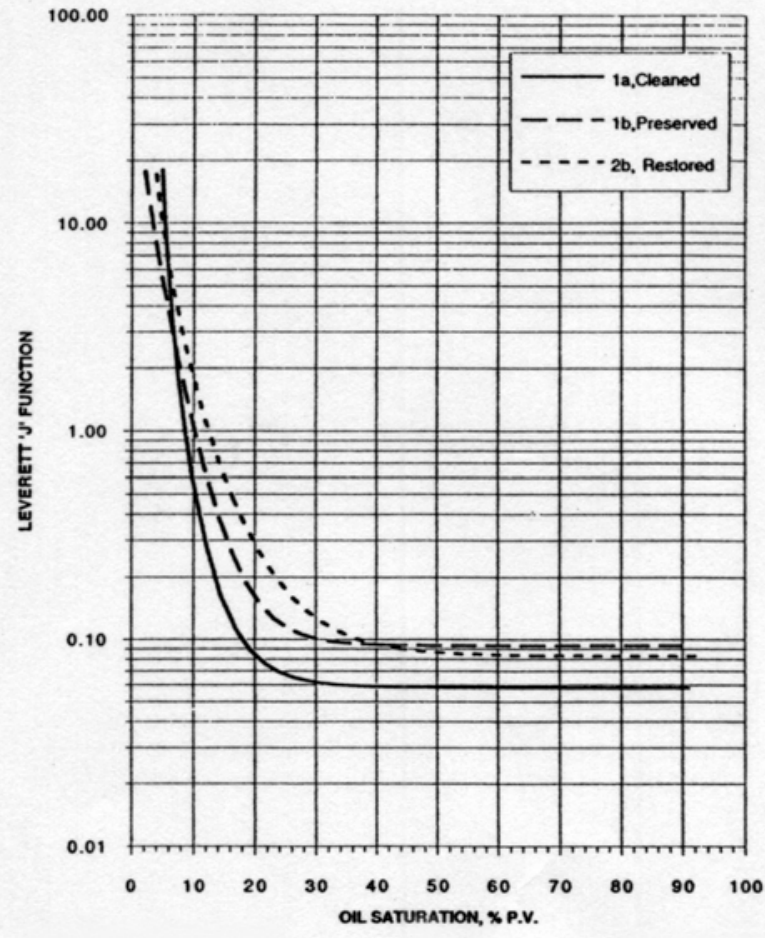

(B)

Figure 7-10. Brine - oil primary imbibition capillary pressure curves from elevated temperature, automated centrifuge data for Anasazi No. 6H-1 well. (A) capillary pressure, psi, and (B) capillary pressure curve, Leverett's J Function.

$\underline{K}_{\text {ew }}$ measurements and oil/brine secondary drainage test: The samples were mounted in flow cells with an overburden pressure of $1,000 \mathrm{psi}(6,895 \mathrm{kpa})$ and heated to $130^{\circ} \mathrm{F}\left(54^{\circ} \mathrm{C}\right)$. Brine was then introduced and a fluid pressure of 500 psi $(3,448 \mathrm{kpa})$ maintained while the $\mathrm{K}_{\mathrm{ew}}$ at residual oil saturation $\left(\mathrm{S}_{\mathrm{or}}\right)$ measurements were taken. The samples were cooled while maintaining the $500 \mathrm{psi}(3,448 \mathrm{kpa})$ fluid pressure. The samples were then placed in the 
centrifuge drainage cells. The cells were heated to $130^{\circ} \mathrm{F}\left(54^{\circ} \mathrm{C}\right)$ and a multi-speed experiment was conducted to determine the secondary drainage capillary pressure curves presented in figure 7-11. The Leverett "J" function curves indicate stronger water wetting in core 1a, with the preserved core $1 \mathrm{~b}$ having the least water wetting condition.

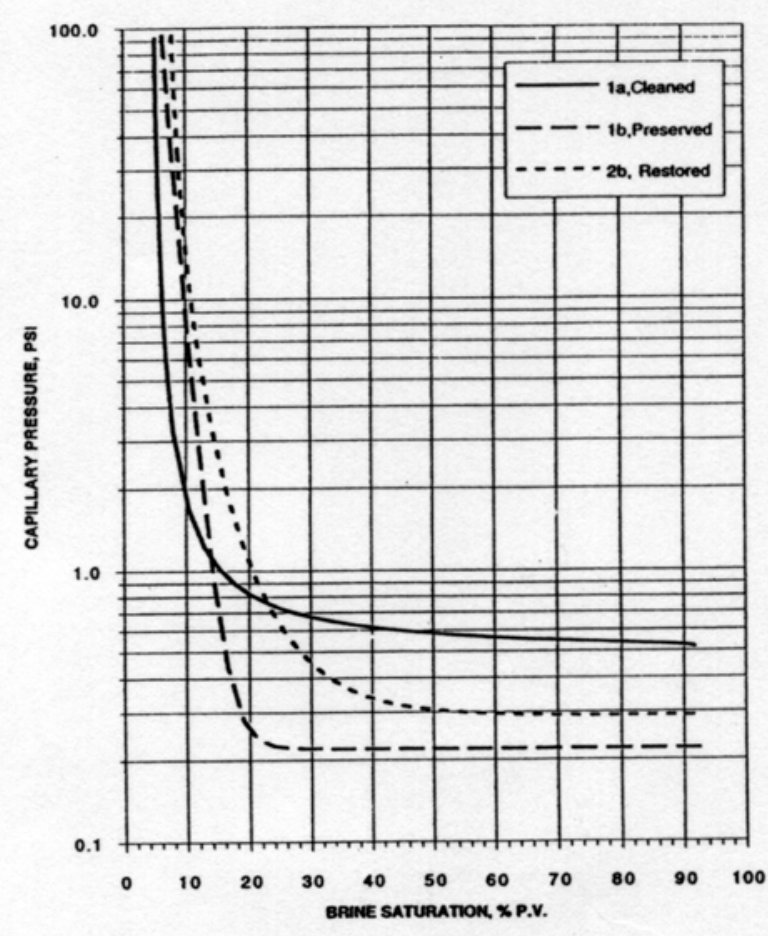

(A)

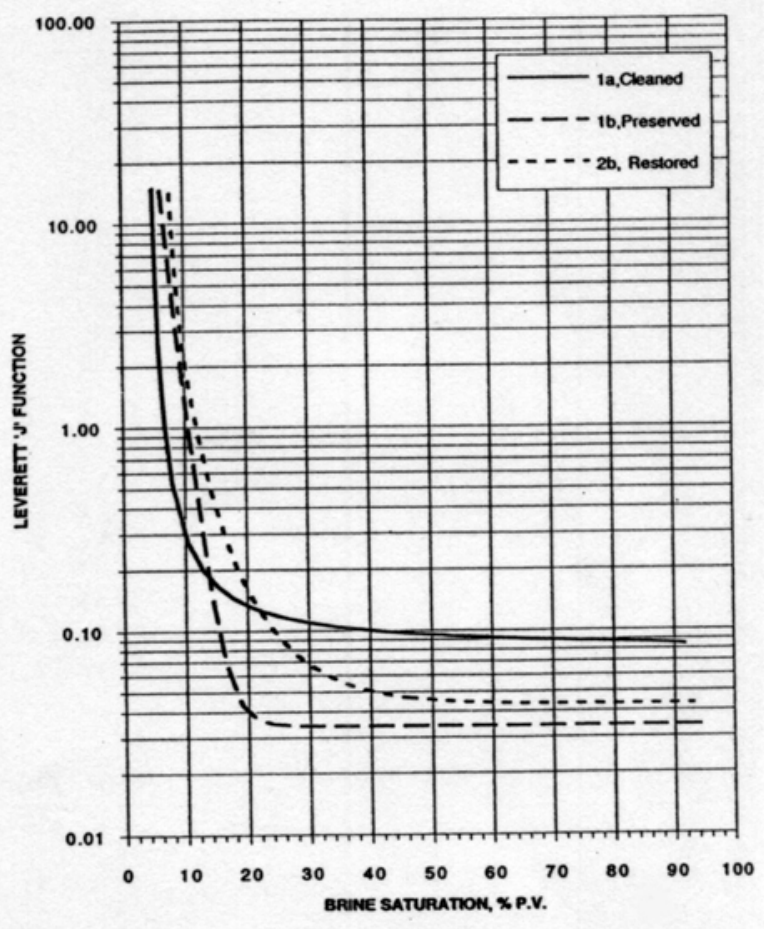

(B)

Figure 7-11. Oil - brine secondary drainage capillary pressure curves from elevated temperature, automated centrifuge data for Anasazi No. 6H-1 well. (A) capillary pressure, psi, and (B) capillary pressure curve, Leverett's J Function.

Brine/oil imbibition relative permeability test: Initial flowing oil permeabilities were measured and then an imbibition capillary pressure experiment was conducted for use in wettability determination. A comparison of the data is given in figure 7-12. The initial permeabilities were fixed to the measured initial flowing permeabilities and the data were history matched to produce the curves. The final oil saturation to which the curves are plotted is the final average saturation in the cores. This explains why the saturations are not as low as the capillary pressure final saturations, which are the saturations calculated at the inflow end of the core.

Oil/brine drainage relative permeability test: Initial flowing brine permeabilities were measured and then a drainage capillary pressure experiment was conducted for use in wettability determination (figure 7-13). A comparison of the data is given in figure 7-12. The initial permeabilities were fixed to the measured flowing permeabilities and the data were history matched to produce the curves. The final oil saturations to which the curves are plotted are the final average saturation in the cores. This explains why the saturations are not as low as the capillary pressure final saturations, which are the saturations calculated at the inflow end of the core. 


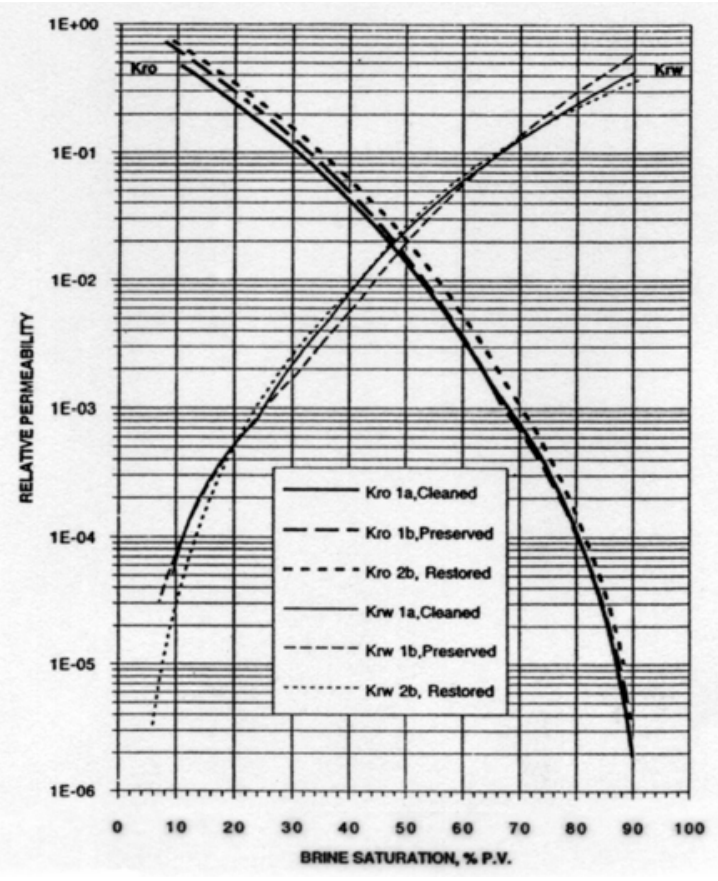

Figure 7-12. Oil - brine relative permeability curves from elevated temperature, automated centrifuge data for Anasazi No. 6H-1 well.

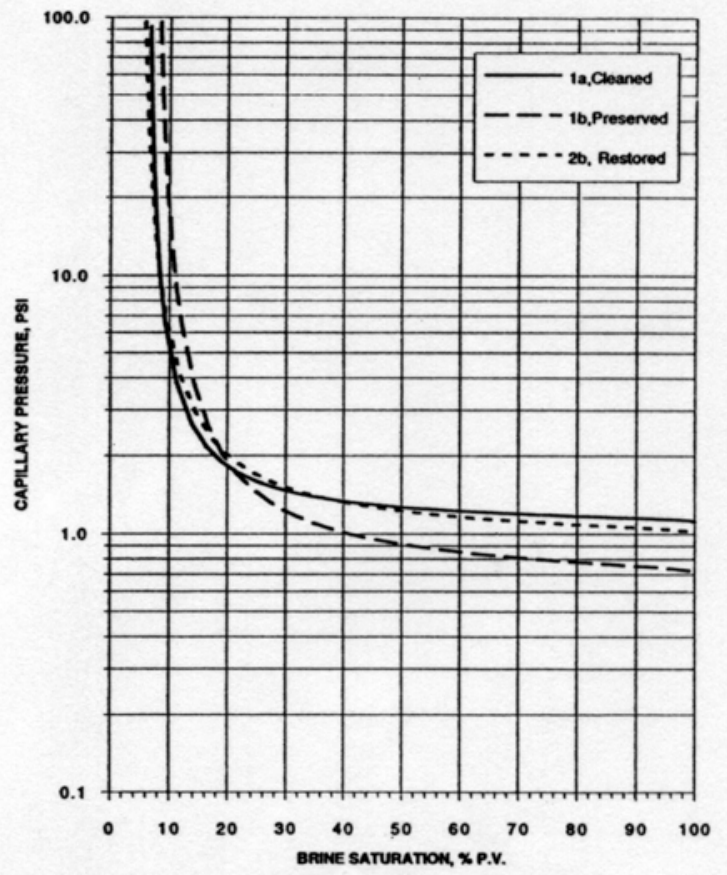

(A)

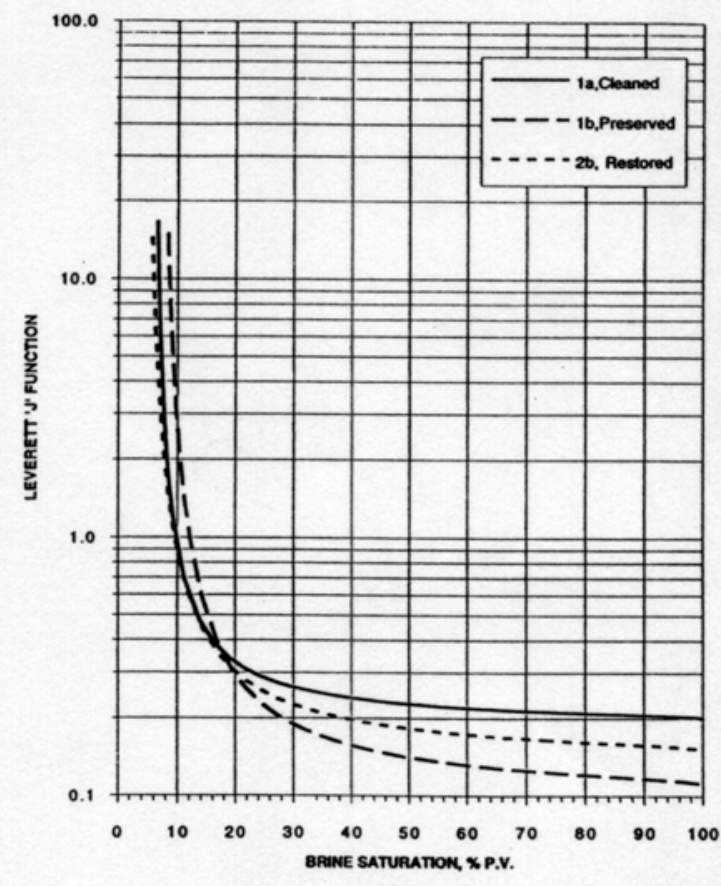

(B)

Figure 7-13. Oil - brine primary drainage capillary pressure curve from elevated temperature, automated centrifuge data for Anasazi No. 6H-1 well. (A) capillary pressure, psi, and (B) capillary pressure curve, Leverett's J Function. 
Gas/oil capillary pressure and relative permeability experiment: A gas/oil drainage capillary pressure experiment was conducted. The data presented in figure 7-14 indicate the expected oil wetting in the presence of gas. The $S_{\text {or }}$ value between 0.8 and 2.5 percent is reflective of the lack of trapping sites in the core material. The slightly higher capillary entry pressure, when compared to the oil/brine system, may be indicative of the non-equilibrium tension measurements used. The samples were mounted in flow cells with an overburden pressure of $1,000 \mathrm{psi}(6,895 \mathrm{kpa})$ and heated to $130^{\circ} \mathrm{F}\left(54^{\circ} \mathrm{C}\right)$. Oil was then introduced and a fluid pressure of $500 \mathrm{psi}(3,448 \mathrm{kpa})$ maintained during resaturation and the effective oil permeability at irreducible water saturation $\left(\mathrm{K}_{\mathrm{eo}}\right.$ at $\left.\mathrm{S}_{\mathrm{wr}}\right)$ measurements taken. The samples were cooled while maintaining the $500 \mathrm{psi}(3,448 \mathrm{kpa})$ fluid pressure. The samples were then placed in the centrifuge drainage cells. The cells were heated to $130^{\circ} \mathrm{F}\left(54^{\circ} \mathrm{C}\right)$ and a single speed experiment was conducted to determine the gas/oil drainage relative permeability curves to oil presented in figure 7-15. The curves agree quite well to values of about $5 \times 10^{-4}$, at which point the cleaned core begins to deviate, due at least in part to the inability of the bimodal model to fit the production data. At the conclusion of the experiment, gas permeability at $\mathrm{S}_{\mathrm{or}}$ and $\mathrm{S}_{\mathrm{wr}}$ was measured and is presented in table 7-8.

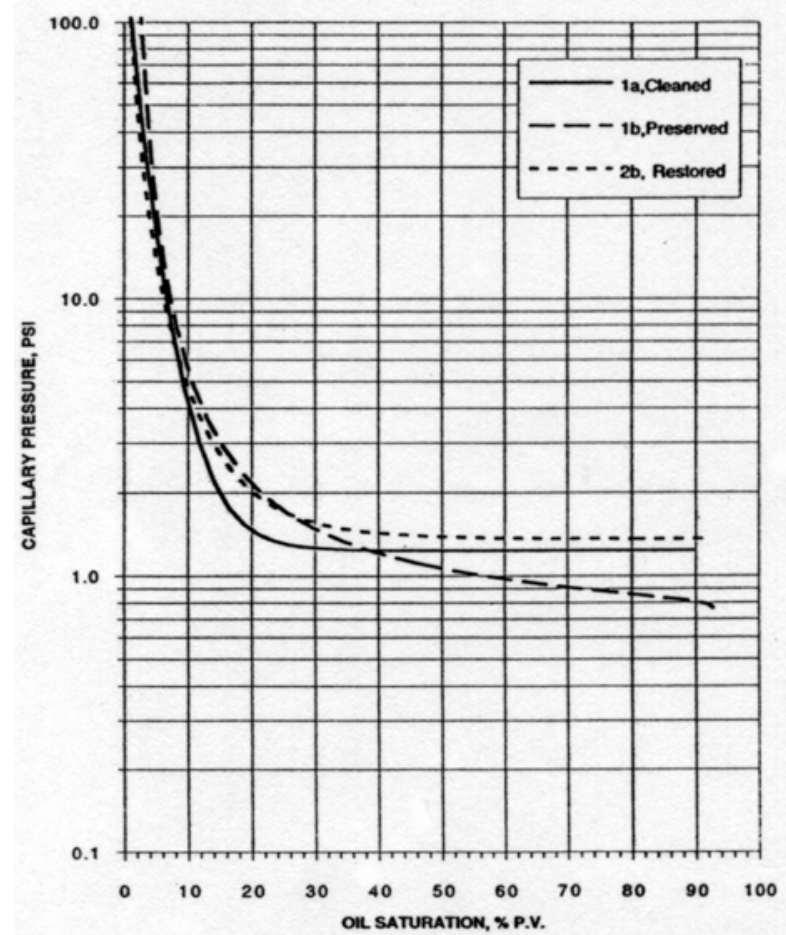

(A)

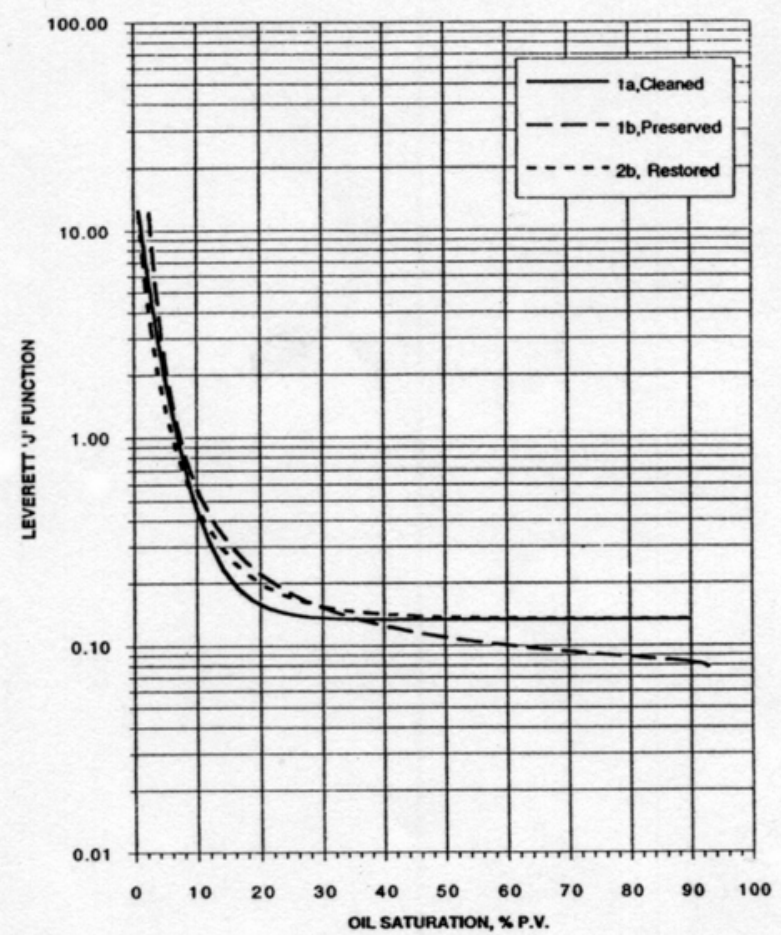

(B)

Figure 7-14. Gas - oil drainage capillary pressure curve from elevated temperature, automated centrifuge data for Anasazi No. 6H-1 well. (A) capillary pressure, psi, and (B) capillary pressure curve, Leverett's J Function. 
Figure 7-15. Gas - oil relative permeability curves from elevated temperature, automated centrifuge data for Anasazi No. 6H-1 well.

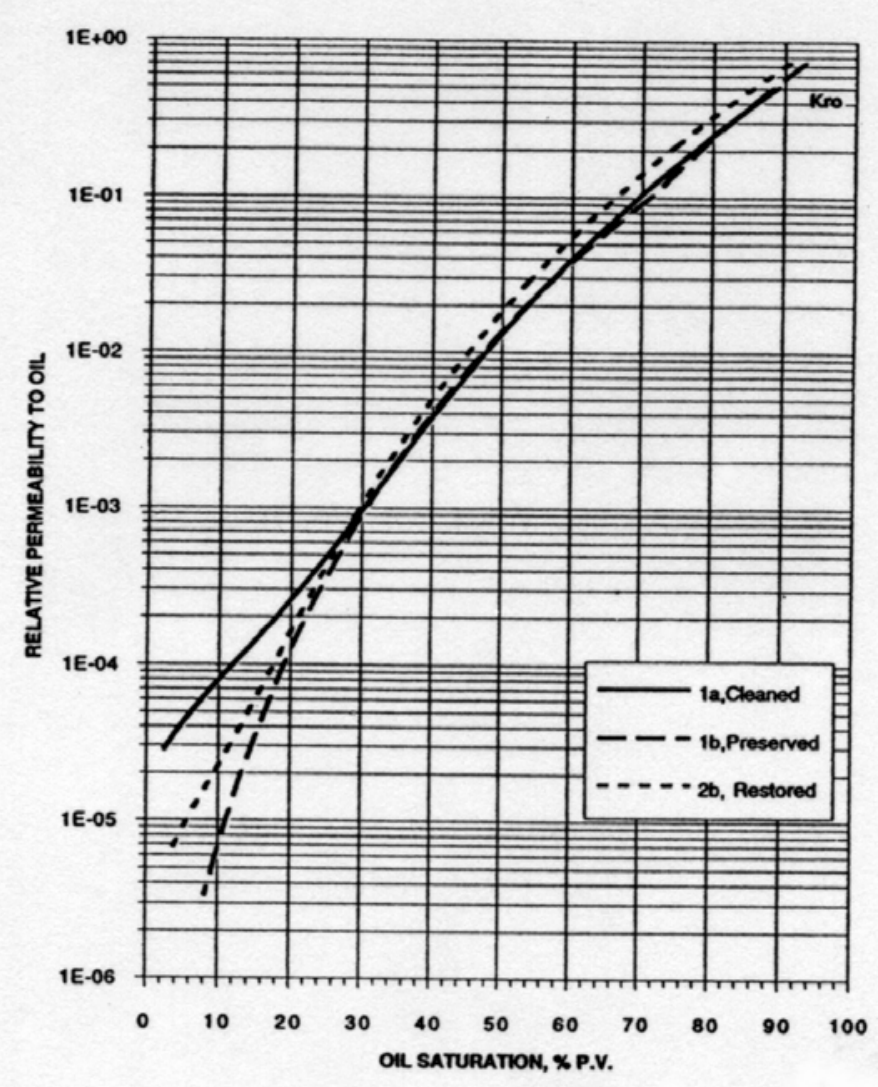

Table 7-8. Permeability and porosity data summary for the Anasazi No. 6H-1.

\begin{tabular}{|c|c|c|c|c|c|c|}
\hline Test No. & Core 1a & Core 1b & Core 2 & Core 2a & Core $\mathbf{2 b}$ & Core $4 a$ \\
\hline Depth (ft) & 5691.210 & 5691.210 & 5691.460 & 5691.460 & 5691.460 & 5691.800 \\
\hline \multicolumn{7}{|c|}{ Initial Core Properties at 500 psi NCS } \\
\hline Length $(\mathrm{cm})$ & 4.097 & 4.252 & 9.073 & 4.470 & 4.257 & 4.262 \\
\hline Average Area $\left(\mathrm{cm}^{2}\right)$ & 11.158 & 11.159 & 11.187 & 11.194 & 11.194 & 11.153 \\
\hline Bulk Volume (cc) & 45.716 & 47.447 & 101.502 & 50.044 & 47.652 & 47.534 \\
\hline Gas Pore Volume (cc) & 8.221 & 8.273 & 17.715 & 8.070 & 9.054 & 7.454 \\
\hline Grain Volume (cc) & 37.495 & 39.174 & 83.787 & 41.974 & 38.598 & 40.080 \\
\hline Gas Porosity (\% Bulk volume) & 17.982 & 17.436 & 17.453 & 16.125 & 19.000 & 15.681 \\
\hline Grain Density (gm/cc) & 2.849 & 2.840 & 2.826 & 2.821 & 2.825 & 2.771 \\
\hline Gas Permeability $\quad(\mathrm{md})$ & 30.000 & 26.400 & 15.100 & 13.600 & 26.700 & 3.800 \\
\hline Oil Permeability No. 1 (md) & 12.950 & 20.710 & & & 18.420 & \\
\hline
\end{tabular}


Table 7-8. (continued)

\begin{tabular}{|c|c|c|c|c|c|c|}
\hline Test No. & Core 1a & Core $1 \mathrm{~b}$ & Core 2 & Core $2 \mathrm{a}$ & Core $\mathbf{2 b}$ & Core $4 a$ \\
\hline \multicolumn{7}{|l|}{ Core Properties at 2,000 psi NCS } \\
\hline Length $(\mathrm{cm})$ & 4.097 & 4.252 & 9.073 & 4.470 & 4.257 & 4.262 \\
\hline Average Area $\left(\mathrm{cm}^{2}\right)$ & 11.125 & 11.106 & 11.148 & 11.150 & 11.160 & 11.111 \\
\hline Bulk Volume (cc) & 45.578 & 47.224 & 101.149 & 49.847 & 47.509 & 47.355 \\
\hline Gas Pore Volume (cc) & 8.083 & 8.050 & 17.362 & 7.873 & 8.911 & 7.275 \\
\hline Gas Porosity (\% Bulk volume) & 17.735 & 17.046 & 17.165 & 15.794 & 18.756 & 15.362 \\
\hline Gas Permeability $\quad(\mathrm{md})$ & 26.500 & 23.100 & 13.200 & 12.300 & 24.400 & 2.900 \\
\hline $\begin{array}{l}\text { Brine Permeability } \\
\text { (as received ) (md) }\end{array}$ & 10.400 & 8.300 & 4.300 & & & 1.000 \\
\hline $\begin{array}{l}\text { Brine Permeability } \\
\text { (at cleaning) (md) }\end{array}$ & 20.200 & & & & 13.800 & \\
\hline \multicolumn{7}{|l|}{ Centrifuge Values* $^{*}$} \\
\hline $\begin{array}{l}\text { Initial Residual Water Saturation } \\
\left(\mathrm{S}_{\mathrm{wri}}\right) \text { (in } \mathrm{S}_{\mathrm{w}} \% \text { Pore volume) }\end{array}$ & 8.990 & 10.240 & & & 7.950 & \\
\hline $\mathrm{K}_{\mathrm{eo}} @ \mathrm{~S}_{\mathrm{wri}}(\mathrm{md})$ & 12.950 & 20.710 & & & 18.420 & \\
\hline $\begin{array}{l}\text { Residual Oil Saturation }\left(\mathrm{S}_{\circ \mathrm{r}}\right) \text { (in } \mathrm{S}_{\circ} \\
\% \text { Pore volume) }\end{array}$ & 6.010 & 5.480 & & & 6.860 & \\
\hline $\begin{array}{l}\text { Water Saturation @ } \mathrm{S}_{\text {or }}\left(\mathrm{S}_{\mathrm{w}} @ \mathrm{~S}_{\mathrm{or}}\right) \\
\text { (in } \mathrm{S}_{\mathrm{w}} \% \text { Pore volume) }\end{array}$ & 93.990 & 94.520 & & & 93.140 & \\
\hline $\mathrm{K}_{\mathrm{ew}} @ \mathrm{~S}_{\mathrm{or}}(\mathrm{md})$ & 16.400 & 16.800 & & & 10.900 & \\
\hline $\begin{array}{l}\text { Residual Water Saturation }\left(\mathrm{S}_{\mathrm{wrf}}\right) \text { (in } \\
\mathrm{S}_{\mathrm{o}} \% \text { Pore volume) }\end{array}$ & 10.790 & 7.910 & & & 9.300 & \\
\hline $\mathrm{K}_{\mathrm{eo}} @ \mathrm{~S}_{\mathrm{wrf}}(\mathrm{md})$ & 9.400 & 18.900 & & & 14.5 & \\
\hline $\begin{array}{l}\text { Residual Oil Saturation } \mathrm{S}_{\text {or }} \text { (in } \\
\mathrm{S}_{0} \% \text { Pore volume) }\end{array}$ & 10.100 & 10.400 & & & 11.700 & \\
\hline $\begin{array}{l}\text { Water Saturation @ } \mathrm{S}_{\mathrm{or}}\left(\mathrm{S}_{\mathrm{w}} @ \mathrm{~S}_{\mathrm{or}}\right) \\
\text { (in } \mathrm{S}_{\mathrm{w}} \% \text { Pore volume) }\end{array}$ & 89.990 & 89.600 & & & 90.720 & \\
\hline $\mathrm{K}_{\mathrm{ew}} @ \mathrm{~S}_{\mathrm{or}}(\mathrm{md})$ & 12.700 & 15.100 & & & 9.860 & \\
\hline $\begin{array}{l}\text { Final Residual Water Saturation } \\
\left(\mathrm{S}_{\mathrm{wr}}\right)\left(\text { in } \mathrm{S}_{\mathrm{w}} \% \text { Pore volume) }\right.\end{array}$ & 9.490 & 7.180 & & & 5.920 & \\
\hline $\mathrm{K}_{\mathrm{eo}} @ \mathrm{~S}_{\mathrm{wrf}}(\mathrm{md})$ & 15.220 & 19.180 & & & 19.370 & \\
\hline $\begin{array}{l}\text { Residual Oil Saturation ( } \mathrm{S}_{\text {or }} \text { ) } \\
\text { (in } \mathrm{S}_{\circ} \% \text { Pore volume) }\end{array}$ & 2.410 & 8.220 & & & 3.220 & \\
\hline $\mathrm{K}_{\mathrm{eg}}{ }^{* *} @ \mathrm{~S}_{\mathrm{or}}(\mathrm{md})$ & 25.700 & 25.900 & & & 22.300 & \\
\hline Final Brine $100 \%$ saturated $(\mathrm{md})$ & 23.700 & 13.400 & & & 14.200 & \\
\hline
\end{tabular}

${ }^{*}$ Centrifuge cores

$$
\begin{aligned}
& 1 \mathrm{a}-\text { cleaned } \\
& 1 \mathrm{~b} \text { - preserved } \\
& 2 \mathrm{~b} \text { - restored }
\end{aligned}
$$

${ }^{*}$ Effective gas permeability

Final saturation determination via Dean-Stark: A Dean-Stark extraction was performed on the core material to determine the final oil and brine saturations, and to check the weightdetermined values used in the study. The material was then cleaned using a sequential-solventflow cleaning procedure using: (1) a 3 percent potassium chloride brine to remove the precipitated salts from the extraction, and (2) toluene and methanol flushes to properly clean the material. 
Gas property measurements: Gas permeability and porosity measurements were made on the cleaned core material at 500 and 2,000 psi (3,448 and 13,790 kpa) net confining stress. The data are presented in table 7-8.

Saturation and $\mathbf{K}_{\mathbf{w}}$ : The dry cores were weighed, evacuated, and degassed brine was introduced. The core holders were then pressurized to $2,000 \mathrm{psi}(13,790 \mathrm{kpa})$ and held for 16 hours at $73^{\circ} \mathrm{F}\left(23^{\circ} \mathrm{C}\right)$. The cores were removed from the cells and weighed. They were then placed in flow permeability cells with an overburden pressure of $1,000 \mathrm{psi}(6,895 \mathrm{kpa})$ and a fluid pressure of $500 \mathrm{psi}(3,448 \mathrm{kpa})$. Flow was established and when stabilized the absolute permeability of the water-saturated rock $\left(\mathrm{K}_{\mathrm{w}}\right)$ measurement was made (see table 7-8).

Primary drainage capillary pressure measurements: After the flowing permeability measurements, the samples were mounted in the centrifuge drainage cells, surrounded with crude oil, and heated to $130^{\circ} \mathrm{F}\left(54^{\circ} \mathrm{C}\right)$. Thirteen centrifuge speed steps were used to define the capillary pressure curves. Each speed was maintained for eight hours before moving on to the next speed. The final average saturations were then extrapolated to infinite time using the production data and a Corey exponent of 2.5 for the extrapolation. The resultant average saturation curve was then converted to the capillary pressure curve at the inflow end of the core using a constrained Hassler-Brunner fit. The samples were cooled to $73^{\circ} \mathrm{F}\left(23^{\circ} \mathrm{C}\right)$ and weighed for saturation determinations. The resulting curves are seen in figure 7-13, and indicate a stronger water wetting nature than the secondary drainage curves seen in figure 7-11. This is evident from the higher Leverett "J" function entry pressure for the primary drainage curves. There appears to be a slight lowering in the entry pressure of the restored-state core, and an even lower value for the preserved core. This effect could be due to a surface oil adsorption which is time dependent, and which requires stronger solvent cleaning than was accomplished using toluene and methanol.

U.S. Bureau of Mines and Amott wettability indices: Both the U.S. Bureau of Mines (USBM) and Amott wettability indices were determined from the primary waterflood and secondary oil flood capillary pressure experiments. The USBM index is the ratio of the areas under the two capillary pressure curves. The areas were calculated to a common pressure of 90 psi $(620 \mathrm{kpa})$. The results ranged in value from -0.33 to -0.49 . These values are commonly classified as mixed wet values with a slightly stronger oil than water wetting. The Amott results were the ratio of the production during the first speed step of the centrifuge divided by the total production during the experiment. This value is an upper limit for the "spontaneous" imbibition value since a slight amount of pressure was actually applied to the cores to produce the initial fluid. The values indicate no spontaneous water production and 6 to 25 percent spontaneous oil production. This spontaneous oil production was at an applied pressure of 0.6 psi $(4.1 \mathrm{kpa})$, while the water production values occurred at about $0.2 \mathrm{psi}(1.4 \mathrm{kpa})$ due to the difference in holder and sample configuration during the two experiments. If a spontaneous value for the oil production is calculated by extrapolating the curves to $0.2 \mathrm{psi}(1.4 \mathrm{kpa})$, the values all become zero as in the water production case. This would be consistent with the USBM results of mixed wettability. The higher entry pressure for the oil curves when compared to the water entry pressures on the preserved and restored cores supports this favorable oil wetting as well. 
Bond number versus $\mathbf{S}_{\text {or }} \underline{\mathbf{S}}_{\mathbf{i}}:$ Figure 7-16 shows the relationship between the residual oil saturation to initial oil saturation $\left(\mathrm{S}_{\mathrm{or}} / \mathrm{S}_{\mathrm{oi}}\right)$ values and the Bond number for the waterflood capillary pressure experiments. The vertical lines are an artifact of the capillary entry pressure for the experiments. The remainder of the curves from about $10^{-7}$ to $10^{-5}$ on figure 7-16 show a film drainage mechanism common to thinning of oil films with increased pressure. The low residuals between 2 to 6 percent reflect the lack of trapping mentioned earlier.

Summary: Centrifuge tests were performed on three core plugs to provide oil-brine and gas-oil capillary pressure, and oil-brine and gas-oil relative permeability curves. The samples were prepared in three ways: core 1a was cleaned but not aged, core $1 \mathrm{~b}$ was preserved, and core $2 \mathrm{~b}$ was cleaned and aged to restore wettability. The tests were performed at $130^{\circ} \mathrm{F}\left(54^{\circ} \mathrm{C}\right)$ with a confining pressure of about 200 psi $(1,379 \mathrm{kpa})$ provided by shrinkable teflon jackets.

The data indicate a mixed wetting

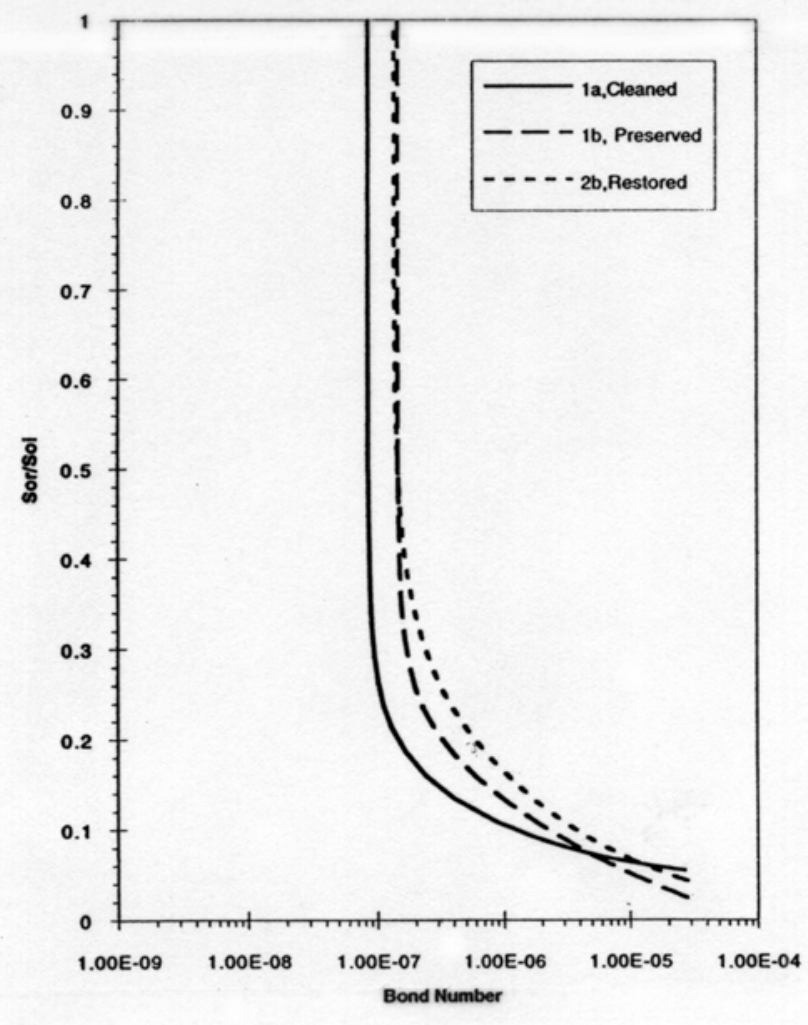

Figure 7-16. Bond number vs. $S_{\text {or }} / S_{\text {oi }}$ curves from elevated temperature, automated centrifuge data for Anasazi No. 6H-1 well.

condition typical of carbonate systems with a slightly stronger oil wetting tendency in the preserved core, and a nearly neutral wetting for the cleaned and unrestored core, with the restored core falling between the others. The dominant feature of the cores is the lack of trapping sites, yielding very low residuals in both the oil and brine phases. This feature overwhelms the slight differences in the wetting states of the core preparation techniques and yields capillary pressure and relative permeability curves that compare quite well.

\section{Rock Compressibility Measurements}

Compressibility testing was conducted on two carbonate samples obtained from the Anasazi Nos. 1 and $6 \mathrm{H}-1$ wells. The core material consisted of one sample of unpreserved limestone exhibiting vugular porosity from the Anasazi No. 1 well, and one unpreserved microporous dolomite sample from the Anasazi No. 6H-1 well.

Compressibility of a porous medium is defined as the relative volume change due to a unit change in applied stress. Three types of compressibilities were determined for both carbonate samples: (1) bulk compressibility $\left(\mathrm{C}_{b}\right),(2)$ the solid (grain) compressibility $\left(\mathrm{C}_{g}\right)$, and (3) the pore volume compressibility $\left(\mathrm{C}_{p}\right)$. The bulk compressibility represents the relative changes in bulk volume of the medium; the grain compressibility represents the relative volumetric change of the solid portion of the medium; and the pore volume compressibility represents the relative change in pore volume. The sample depth, pre-test bulk density, 
effective grain density, and effective porosity for both samples are presented in table 7-9. In addition to the compressibility determinations, each specimen was loaded under triaxial conditions for determination of quasi-static elastic moduli and Poisson's ratio. The results of this work are summarized in tables 7-10 through 7-13.

Table 7-9. Pre-test sample conditions and physical properties for selected samples from the Anasazi Nos. 1 and $6 H-1$ wells.

\begin{tabular}{|c|c|c|c|c|c|c|c|c|}
\hline \multirow[b]{2}{*}{$\begin{array}{c}\text { Sample } \\
\text { Depth (ft) }\end{array}$} & \multirow[b]{2}{*}{$\begin{array}{l}\text { Rock } \\
\text { Type }\end{array}$} & \multirow[b]{2}{*}{$\begin{array}{l}\text { Length } \\
\text { (in) }\end{array}$} & \multirow[b]{2}{*}{$\begin{array}{l}\text { Diameter } \\
\text { (in) }\end{array}$} & \multicolumn{3}{|c|}{ Pre-Test Density $(\mathrm{gm} / \mathrm{cm} 3)$} & \multirow[b]{2}{*}{$\begin{array}{l}\text { Porosity* } \\
\text { (\%) }\end{array}$} & \multirow[b]{2}{*}{$\begin{array}{l}\text { Permeability } \\
\text { to Gas (md) }\end{array}$} \\
\hline & & & & $\begin{array}{c}\text { Saturated } \\
\text { Bulk }\end{array}$ & $\begin{array}{c}\text { Dry } \\
\text { Bulk }\end{array}$ & Grain & & \\
\hline $\begin{array}{c}5,648.5- \\
5,648.9\end{array}$ & $\begin{array}{c}\text { Limestone } \\
\text { (Anasazi No. } 1 \\
\text { Well) }\end{array}$ & 3.724 & 1.998 & 2.390 & 2.244 & 2.698 & 16.83 & 51.45 \\
\hline $\begin{array}{c}5,692.0- \\
5,692.4\end{array}$ & $\begin{array}{c}\text { Dolomite } \\
\text { (Anasazi No. 6H-1 } \\
\text { Well) }\end{array}$ & 3.881 & 1.997 & 2.588 & 2.487 & 2.814 & 11.62 & 0.65 \\
\hline
\end{tabular}

${ }^{*}$ Effective grain density and porosity determined - reflects only interconnected pore space

Simulated in-situ conditions were used for the compressibility and triaxial compression tests. The testing scenario was based on an approximate average horizontal stress gradient of 0.65 pounds per square inch per foot $(\mathrm{psi} / \mathrm{ft}[15 \mathrm{kpa} / \mathrm{m}])$, a reservoir pore pressure of 2,000 $\mathrm{psi}$ $(13,790 \mathrm{kpa})$, and a vertical stress gradient of $1 \mathrm{psi} / \mathrm{ft}(23 \mathrm{kpa} / \mathrm{m})$ (overburden stress). The target in-situ pressures for this test program are shown in table 7-10.

Table 7-10. Target pressures for simulated in-situ conditions.

\begin{tabular}{|c|c|c|c|c|c|}
\hline Rock Type & $\begin{array}{c}\text { Depth } \\
\text { (ft) }\end{array}$ & $\begin{array}{c}\text { Target Confining } \\
\text { Pressure (psi) }\end{array}$ & $\begin{array}{c}\text { Target Pore } \\
\text { Pressure (psi) }\end{array}$ & $\begin{array}{c}\text { Target Stress } \\
\text { Difference (psi) }\end{array}$ & $\begin{array}{c}\text { Axial Stress } \\
\text { (psi) }\end{array}$ \\
\hline Limestone & $5,648.5-.9$ & 3,670 & 2,000 & 1,980 & 5,650 \\
\hline Dolomite & $4,592.0-.4$ & 3,700 & 2,000 & 1,990 & 5,690 \\
\hline
\end{tabular}

TerraTek, Inc. (1995) presented details on sample preparation and testing conditions. Table 7-11 presents the compressibility and Biot's coefficient under hydrostatic stress conditions. Table 7-12 presents the quasi-static mechanical properties determined from the triaxial compression segment of the compressibility tests. Table 7-13 presents the compressibilities determined under uniaxial strain conditions. Both the bulk compressibility (defined under uniaxial strain boundary conditions as the axial compaction coefficient $\left[\mathrm{C}^{u}{ }_{b p}\right]$ ) and pore volume compressibilities $\left(\mathrm{C}_{p p}^{u}\right)$ are provided in table $7-13$. The pore pressure range from which the compressibilities were calculated and are also included in table 7-13. 
Table 7-11. Compressibilities determined from hydrostatic compression for samples from the Anasazi Nos. 1 and 6H-1 wells.

\begin{tabular}{|c|c|c|c|c|c|c|}
\hline \begin{tabular}{|c} 
Sample \\
Depth (ft)
\end{tabular} & Rock Type & $\begin{array}{c}\text { Stress Range } \\
\text { (psi) }\end{array}$ & $\begin{array}{c}\text { Grain } \\
\text { Compressibility } \\
\left(10^{-8} \mathrm{psi}^{-1}\right)\end{array}$ & \begin{tabular}{|c|} 
Bulk \\
Compressibility \\
$\left(10^{-6} \mathrm{psi}^{-1}\right)$
\end{tabular} & $\begin{array}{c}\text { Pore Volume } \\
\text { Compressibility } \\
\left(10^{-5} \mathrm{ps}^{-1}\right)\end{array}$ & $\begin{array}{c}\text { Biot's } \\
\text { Constant }\end{array}$ \\
\hline \multirow{4}{*}{$\begin{array}{l}5,648.5- \\
5,648.9\end{array}$} & \multirow{4}{*}{$\begin{array}{c}\text { Limestone } \\
\text { (Anasazi No. } 1 \\
\text { Well) }\end{array}$} & 60 to 320 & & 21.593 & 12.830 & 0.998 \\
\hline & & 525 to 1,956 & 5.1203 & & & \\
\hline & & 2,243 to 2,807 & & 4.0396 & 2.4002 & 0.987 \\
\hline & & 3,083 to 3,636 & & 1.7226 & 1.0235 & 0.970 \\
\hline \multirow{4}{*}{$\begin{array}{l}5,692.0- \\
5,692.4\end{array}$} & \multirow{4}{*}{$\begin{array}{c}\text { Dolomite } \\
\text { (Anasazi } \\
\text { No. } 6 \mathrm{H}-1 \\
\text { Well) }\end{array}$} & 75 to 315 & & 1.6797 & 1.4468 & 0.994 \\
\hline & & 547 to 1,805 & 1.0400 & & & \\
\hline & & 2,368 to 2,910 & & \begin{tabular}{|l|}
1.7074 \\
\end{tabular} & 1.4706 & 0.994 \\
\hline & & 3,050 to 3,690 & & 1.2950 & 1.1154 & 0.992 \\
\hline
\end{tabular}

Table 7-12. Quasi-static mechanical properties determined from triaxial compression for samples from the Anasazi Nos. 1 and $6 \mathrm{H}-1$ wells.

\begin{tabular}{|c|c|c|c|c|c|c|}
\hline \multirow{2}{*}{$\begin{array}{l}\text { Sample } \\
\text { Depth (ft) }\end{array}$} & \multirow[t]{2}{*}{ Rock Type } & \multirow{2}{*}{\multicolumn{2}{|c|}{$\begin{array}{l}\text { Axial Stress Difference Range for } \\
\text { Properties Calculations (psi) }\end{array}$}} & \multicolumn{3}{|c|}{ Triaxial Compression Moduli $\left(10^{6} \mathrm{psi}\right)$} \\
\hline & & & & Young's & Bulk & Shear \\
\hline $5,648.5-.9$ & Limestone & 610 to 1,390 & 0.20 & 2.37 & 1.30 & 0.99 \\
\hline $5,692.0-.4$ & Dolomite & 605 to 1,390 & 0.15 & 3.21 & \begin{tabular}{|l|}
1.51 \\
\end{tabular} & 1.40 \\
\hline
\end{tabular}

Table 7-13. Parameters determined during uniaxial strain/pore pressure drawdown segment.

\begin{tabular}{|c|c|c|l|l|}
\hline $\begin{array}{c}\text { Sample } \\
\text { Depth (ft) }\end{array}$ & Rock Type & $\begin{array}{c}\text { Pore Pressure } \\
\text { Stress Range (psi) }\end{array}$ & $\begin{array}{c}\text { Compaction Coefficient } \\
\left(\mathbf{C}_{\mathrm{b}}{ }^{\mathrm{u}} \mathbf{1 0}^{-7} / \mathbf{p s i}\right)\end{array}$ & $\begin{array}{c}\text { Pore Volume Compressibility } \\
\left(\mathbf{C}_{\mathrm{p}}{ }^{\mathrm{u}} \mathbf{1 0}^{-6} / \mathbf{p s i}\right)\end{array}$ \\
\hline $5,648.5-.9$ & Limestone & 1,935 to 300 & 3.9263 & 2.3329 \\
\hline $5,692.0-.4$ & Dolomite & 1,915 to 275 & 3.6977 & 3.1849 \\
\hline
\end{tabular}




\title{
CHAPTER VIII \\ MECHANISTIC RESERVOIR SIMULATION STUDIES
}

\author{
W.E. Culham \\ REGA Inc.
}

\section{Introduction}

Two processes, with appropriate variations, were evaluated (from a standpoint of oil recovery and economics) for implementing in a field pilot or demonstration project in Anasazi or Runway fields. The first is the waterflood, which can use fluid properties suitable for black oil reservoir studies. The second recovery process is $\mathrm{CO}_{2}$-gas injection. Since $\mathrm{CO}_{2}$ processes require composition data, more comprehensive fluid-property data was needed. Prior to evaluation of the two processes it was necessary to model and history match the primary production phase of the Anasazi and Runway reservoirs. Thus, the following general class of simulation studies was performed:

1. primary depletion (history match),

2. waterflood, and

3. $\mathrm{CO}_{2}$ flood.

A compositional simulation approach was used to model all three processes. A compositional approach properly accounts for oil vaporization (high API gravity oils) during primary depletion and will provide the correct oil compositions to subsequently assess $\mathrm{CO}_{2}$ flooding potential. A black oil approach could have been used for the waterflood study, but again, potential compositional changes and their impact on resaturation of the oil with gas during fill up would be most rigorously accounted for in a compositional approach. Thus, compositional simulation was selected for all process evaluations.

Prediction case runs were conducted to: (1) assess the additional oil recovery that would be obtained by injecting $\mathrm{CO}_{2}$, (2) investigate the optimum number of injection wells, their locations, and their configuration (vertical versus horizontal), (3) evaluate reservoir operating pressure (controls miscibility), (4) investigate produced gas re-injection to reduce $\mathrm{CO}_{2}$ utilization and cost, and (5) use of water injection instead of $\mathrm{CO}_{2}$.

\section{One- and Two-Dimensional Compositional Simulation Studies}

To provide some initial insight into the basic production mechanisms of the Anasazi and Runway reservoirs, some simple one- and two-dimensional compositional simulation studies were conducted prior to developing final reservoir description models and the final threedimensional simulation studies. In addition to gaining insight into possible production mechanisms, the simulation studies were used to estimate a fluid bubble-point pressure that might be realized if the reservoirs were re-pressured after producing the current volumes of oil and gas. This bubble-point data was used for preparing fluid samples for $\mathrm{CO}_{2}$ swelling tests discussed in the previous chapter. 


\section{Model Description}

The bulk volume of the reservoir required to roughly match observed pressureproduction conditions was established with a series of one-dimensional simulation runs that adjusted reservoir bulk volume until a reasonable match of observed production data (GOR) was obtained. This volume was used to guide the overall volume of the two-dimensional model (2,500 feet X 2,500 feet X 100 feet [762 m X 762 m X 30 m] - Anasazi reservoir units only).

The geologic model was a simplistic two-unit model consisting of a dolomite unit and a limestone unit. The homogeneous units were assigned an average thickness of 70 feet $(21 \mathrm{~m})$ and 30 feet $(9 \mathrm{~m})$ for the dolomite and limestone units respectively. Several simulation runs were used to arrive at an overall vertical to horizontal permeability $\left(\mathrm{k}_{\mathrm{v}} / \mathrm{k}_{\mathrm{h}}\right)$ ratio of 0.02 . This gave the best GOR match of ratios investigated. The dolomite unit was assigned a uniform lateral permeability of 10.0 md and a vertical permeability of 0.2 md using the $\mathrm{k}_{\mathrm{v}} / \mathrm{k}_{\mathrm{h}}=0.02$. The limestone unit, at the base of the Desert Creek zone, was assigned a uniform lateral permeability of $200 \mathrm{md}$ and a vertical permeability of $4.0 \mathrm{md}$. The average uniform porosities assigned to the dolomite and limestone units were 10.4 percent and 9.0 percent respectively. An initial oil saturation of 0.85 and an initial irreducible water saturation of 0.15 were used. The initial pressure was set to 2,260 psia $(15,583 \mathrm{kpa})$. The numerical grid for the model consisted of $200 \mathrm{x}$-direction blocks, one y-direction block, and $20 \mathrm{z}$-direction blocks. The dolomite and limestone geologic units were assigned 10 layers (made up of $200 \mathrm{x}$-direction blocks, one y-direction block, and $10 \mathrm{z}$-direction blocks).

\section{Fluid Properties and Production Data}

An equation of state was calibrated using black oil PVT data from the Anasazi reservoir and the Jack reservoir (figure 1-1) fluid properties study was used to provide C7+ characterization. A nine pseudo-component representation of the fluid was developed which provided a good match of volumetric, fluid-property data available from the Anasazi reservoir fluid study. The calibrated equation of state was used in the compositional simulations to conduct the simple mechanistic reservoir studies.

As discussed earlier, the actual well by well, and thus field production data, were organized in data files formatted for comparison with simulation production results. The actual historic monthly production data were used as input to the simulations during the history match phases.

\section{Stimulation Study Procedure}

The simplistic two-dimensional models and compositional simulation were used to history match the production performance of the Anasazi reservoir through March 1995. The main parameters investigated were the overall vertical to lateral permeability ratio, and the degree of communication between the dolomite and limestone units. A qualitative match rather than a detailed match was used for assessing the results. 


\section{Study Results}

The first notable result was that to provide a reasonable match of reservoir response, particularly during the liquid expansion phase of production, an initial oil-in-place value of 8.2 million stock tank barrels (MMSTB [1.3 million $\mathrm{m} 3]$ ) was needed. This compares to an approximate volumetric value of 5.3 $\operatorname{MMSTB}\left(0.8\right.$ million $\left.\mathrm{m}^{3}\right)$. The oil in place needed to support the correct modeling of primary depletion thus exceeds volumetric data by over 3.0 MMSTB $\left(0.5\right.$ million $\left.\mathrm{m}^{3}\right)$. Full three-dimensional studies were used later to identify the reason for this difference.

Simulation results for the $\mathrm{k}_{\mathrm{v}} / \mathrm{k}_{\mathrm{h}}=0.02$ case results for the Anasazi reservoir are presented in figures 8-1 and 8-2. Figure 8-1A presents field oil production for the Anasazi reservoir versus time. These data were used as input to the model via single-well, monthly, oilrate specifications. Figures 8-1B and 8-1C present the simulation production and the observed, field-gas production rate and the GOR (predicted values represented by solid lines and historic data by + symbols). The match between predicted and observed data is considered reasonable, given the simplicity of the two-dimensional geologic model, for understanding basic reservoir production mechanisms. The initial constant GOR period, representing the liquid expansion portions of the depletion, is well matched. The rate of GOR increase and ultimate leveling off reflects fluid migration between the dolomite/limestone intervals and gas segregation via gravity facies. The gas segregation after 1,461 days of production clearly shows in figure 8-2. This figure shows higher gas saturation buildups at the top of the dolomite (layer 1) and top of the limestone (layer 11).

Figure 8-1D illustrates the average reservoir pressure decline to the current expected value of 400 to $500 \mathrm{psi}(2,758-3,448 \mathrm{kpa})$. Figures $8-1 \mathrm{E}$ and $8-1 \mathrm{~F}$ present oil production and oil in place from, and in, the two geologic units respectively. Figure 8-1E shows that over 90 percent of the production comes from the limestone interval. However, figure $8-1 \mathrm{~F}$ illustrates that despite the major portion of production being from the limestone interval, there is not a corresponding decrease in the oil in place in the limestone interval. This behavior clearly supports the gravity drainage of oil from the upper dolomite interval into the lower limestone interval, from which the producing well's major share of production rises (figure 8-1E). This qualitative assessment prompted further analysis, and since the simulator provides data that summarizes the flow of oil between the dolomite and limestone intervals, it was possible to determine the ratio of this flow to the limestone production. Figure 8-3 shows the various fluid rates (in bbls of oil per month [BOPM]) used in the analysis, where $\mathrm{q}_{\mathrm{d}}$ and $\mathrm{q}_{1}$ are dolomite and limestone production respectively at the well, and $\mathrm{q}_{\mathrm{v}}$ is vertical flow from the dolomite interval (supra-mound) to the limestone interval (mound core). Table 8-1 provides specific data on the relation of gravity-drained oil into the limestone interval versus actual limestone interval production.

These data, specifically $\mathrm{q}_{\mathrm{v}} / \mathrm{q}_{1}$, show that after June 1993, the production rate from the limestone interval approximately equals the volume of oil draining from the dolomite interval into the limestone interval. This type of production behavior is clearly evident in figure 8-1A. After the relatively rapid production rate decline, the production rate becomes constant at about 300 BOPD. This corresponds to the time identified in table 8-1 when $\mathrm{q}_{\mathrm{v}}$ approximately equals $\mathrm{q}_{\mathrm{l}}$, and is interpreted as representing the slower gravity drainage replenishment of the limestone interval. The impact of production from the dolomite interval, $\mathrm{q}_{\mathrm{d}}$, is minimal since it represents a small fraction of the total production. Additional simulation runs projected a 22 percent recovery factor under primary depletion (through the year 2020). 


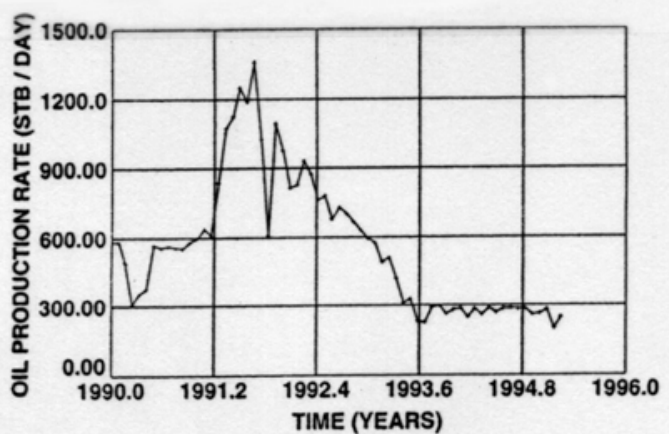

(A)

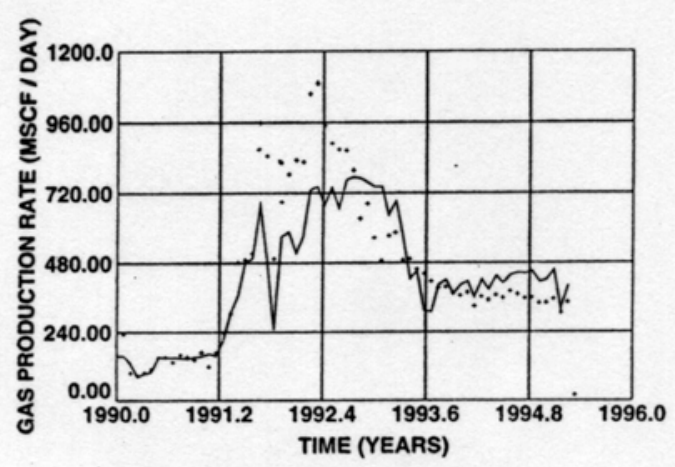

(B)

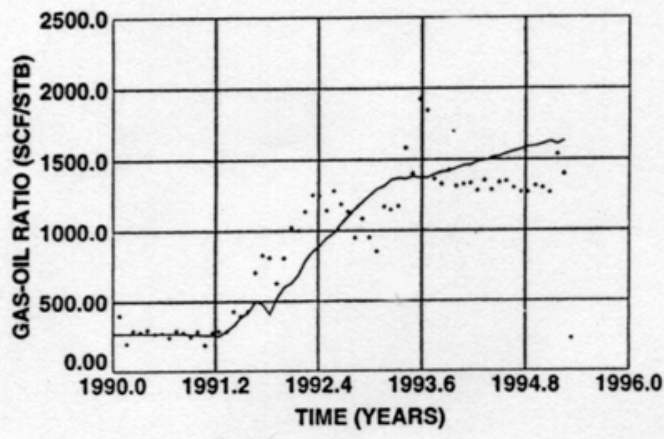

(C)

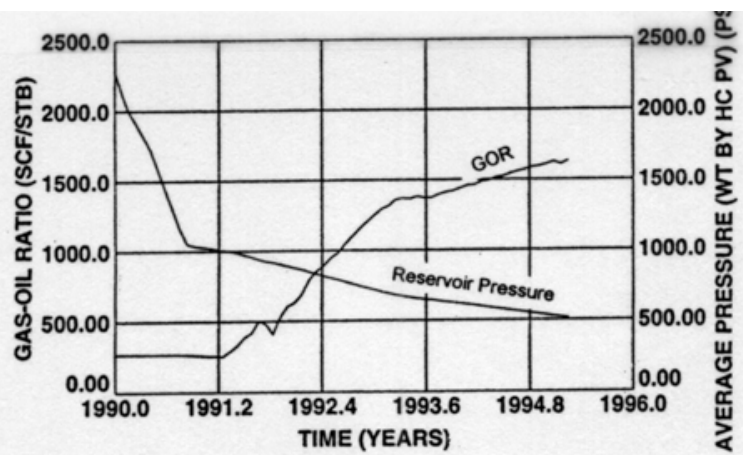

(D)

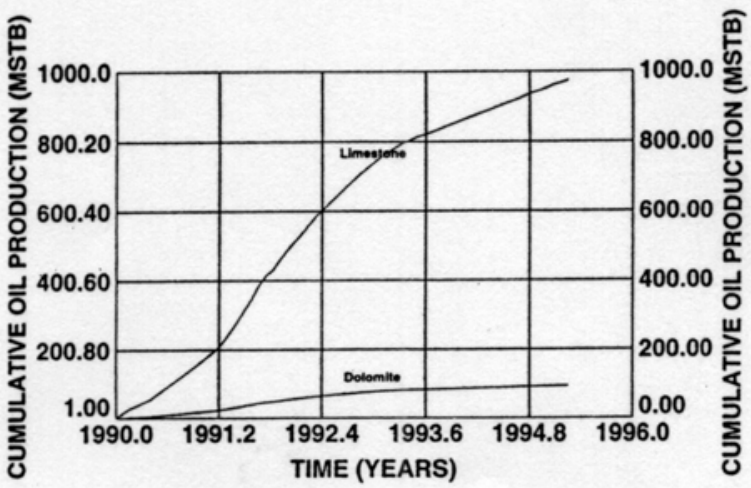

(E)

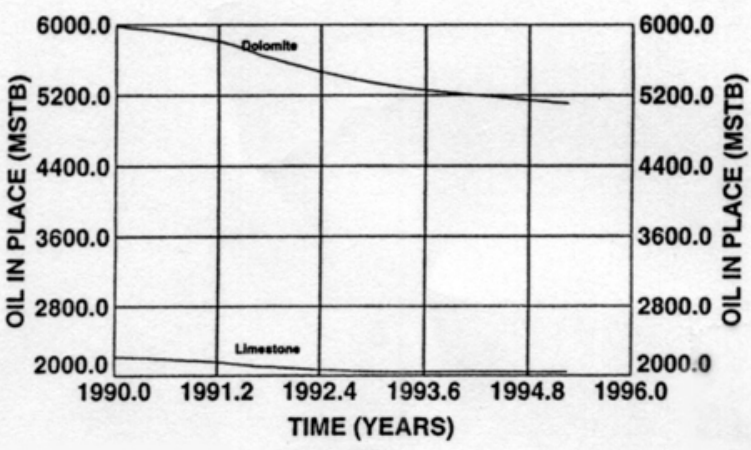

(F)

Figure 8-1. Results of two-dimensional reservoir simulation of the Anasazi field $\left(k_{\sqrt{ }} / k_{h}\right.$ ratio $=$ 0.02 ). (A) historic oil production rate vs. time, (B) predicted (solid line) and actual (+ symbol) gas production data vs. time, (C) predicted (solid line) and actual (+ symbol) GORs vs. time, (D) predicted GOR and reservoir pressure vs. time, (E) predicted limestone and dolomite oil production vs. time, and $(F)$ predicted limestone and dolomite oil-in-place variation with time. 


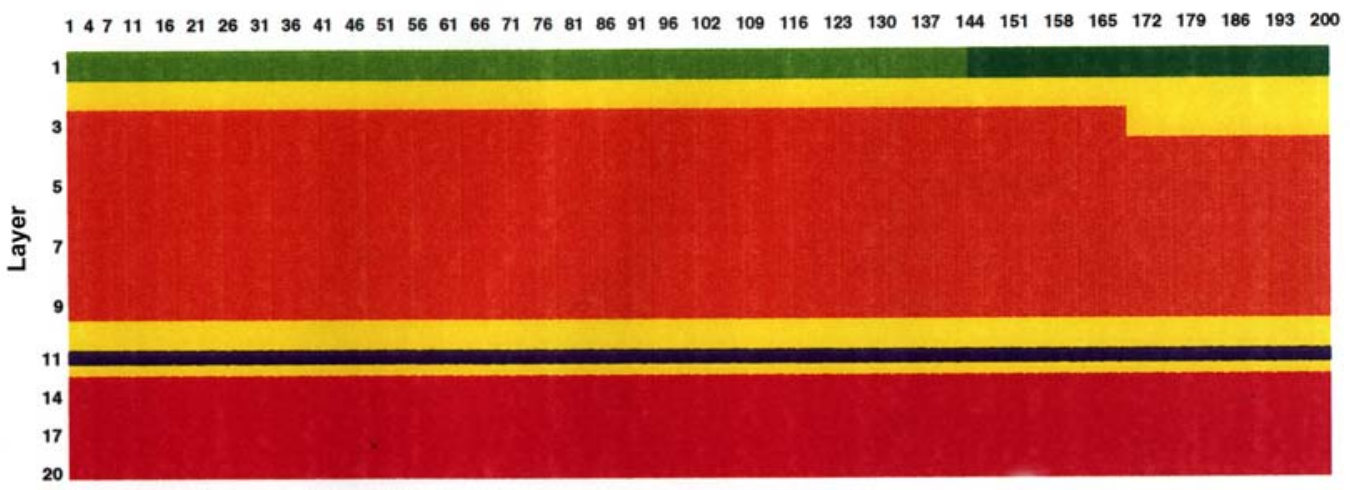

Distance

SHUT-IN : PRODUCER

FRONT XZ PLANE FOR $Y=1$

0.0

GAS SATURATION (FRACTION)

Figure 8-2. Two-dimensional reservoir simulation of the Anasazi field showing gas saturation for XZ plane after 1,461 days of production on January 1, 1994.

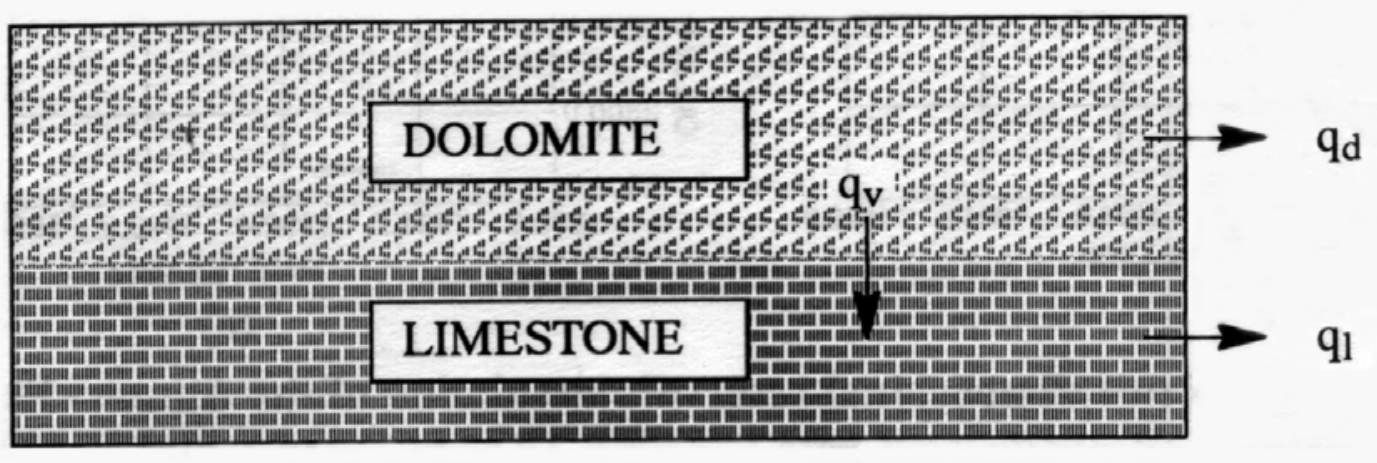

Figure 8-3. Schematic reservoir simulator model of the Anasazi reservoir. Arrows indicate fluid-flow directions.

Table 8-1. Analysis of gravity drainage behavior.

\begin{tabular}{|c|l|l|l|l|}
\hline Month Ending & \multicolumn{4}{|c|}{ Fluid Rates } \\
\hline & \multicolumn{1}{|c|}{$\mathbf{q}_{\mathrm{d}}$ : BOPM } & \multicolumn{1}{|c|}{$\mathbf{q}_{\mathbf{q}}:$ BOPM } & $\mathbf{Q}_{\mathbf{v}}:$ BOPM & $\mathbf{q}_{\mathbf{v}} / \mathbf{q}_{\mathbf{l}}$ \\
\hline $1 / 31 / 90$ & $1,889.70$ & $16,121.30$ & $11,069.10$ & 0.687 \\
\hline $6 / 30 / 90$ & $1,787.00$ & $15,222.90$ & $10,553.60$ & 0.693 \\
\hline $1 / 31 / 91$ & $2,101.50$ & $17,642.00$ & $12,515.90$ & 0.709 \\
\hline $6 / 30 / 91$ & $3,826.00$ & $33,645.90$ & $24,458.20$ & 0.727 \\
\hline $1 / 31 / 92$ & $2,196.00$ & $23,041.20$ & $19,755.10$ & 0.857 \\
\hline $6 / 30 / 92$ & $1,910.30$ & $21,461.60$ & $17,970.10$ & 0.837 \\
\hline $1 / 31 / 93$ & $1,333.20$ & $16,462.20$ & $14,003.10$ & 0.851 \\
\hline $6 / 30 / 93$ & 683.70 & $9,127.00$ & $9,310.00$ & 1.020 \\
\hline $1 / 31 / 94$ & 585.60 & $8,250.40$ & $8,089.40$ & 0.981 \\
\hline $6 / 30 / 94$ & 515.90 & $7,555.30$ & $7,323.70$ & 0.969 \\
\hline $1 / 31 / 95$ & 529.00 & $8,153.00$ & $7,241.10$ & 0.888 \\
\hline
\end{tabular}




\section{Development of an Equation of State}

One of the first steps in conducting compositional simulation studies of the Anasazi and Runway reservoirs was the calibration, or tuning, of an equation of state to provide a means of calculating, or predicting, the complex phase behavior associated with $\mathrm{CO}_{2}$-displacement processes. A Peng-Robinson equation of state was tuned using all the experimental fluid property data available on the Anasazi reservoir. This included the original black-oil PVT fluid study and the $\mathrm{CO}_{2}$-swelling test data. Two fluid characterizations employing 11 and 13 pseudocomponents were successfully used in the calibration work. Both characterizations, using equation of state parameters derived from the tuning work, were used to reliably match all experimental data. Also, the calibrated equation of state was used to conduct a series of multiple contact experiments designed to approximately model a $\mathrm{CO}_{2}$-displacement process. Results of this work provided insight into the conditions (compositions and pressures) required to develop miscibility.

Well test analysis of various Paradox Basin wells was finalized with the completion of analysis work on the Big Sky No. 6E well (NW1/4SW1/4 section 6, T. 42 S., R. 25 E., SLBL). The test was successfully interpreted using a homogeneous model, which is consistent with production data since only the supra-mound interval is present and should behave as a singleporosity system. To successfully analyze other wells (for example the Anasazi No. 1), a dualproperty model was required to represent the fluid communication between the supra-mound and mound-core intervals. Figures 8-4 and 8-5 illustrate the quality of the match (computed responses are represented by solid lines and measured pressure data by the + symbol) and the reservoir parameters required to achieve this match.

Employing fluid property data (represented via a tuned equation of state) and rock

property data, one-, two-, and three-dimensional models were successfully developed to simulate both primary depletion and $\mathrm{CO}_{2}$-displacement processes. Optimum numerical solution procedures were also determined to reduce computer time required for both one- and threedimensional simulation runs. A series of one-dimensional, $\mathrm{CO}_{2}$-displacement tests for various reservoir-operating pressures were conducted using the original Anasazi reservoir fluid composition. These tests indicated that miscibility would be developed between 2,500 and 3,000 psi (17,238 and 20,685 Kpa). Three plots (figure 8-6) which show the variation of composition of both liquid and vapor phases as a function of time for a selected cell in the onedimensional model, illustrate the development of miscibility (3,000 pounds per square inch absolute [psia], 20,685 Kpa) or near miscibility (2,500 psia [17,238 Kpa).

\section{Reservoir Simulation: Anasazi Field}

The reservoir analysis for the Anasazi field required a field-scale reservoir simulator. Enhanced recovery through $\mathrm{CO}_{2}$-flooding and waterflooding were evaluated using a compositional simulation. Variations in carbonate lithotypes, porosity, and permeability were incorporated into the simulation in order to accurately predict reservoir response (Lorenz and others, 1997). History matches were made, by tying to previous production and reservoir pressure history, so that future reservoir performance could be confidently predicted. 

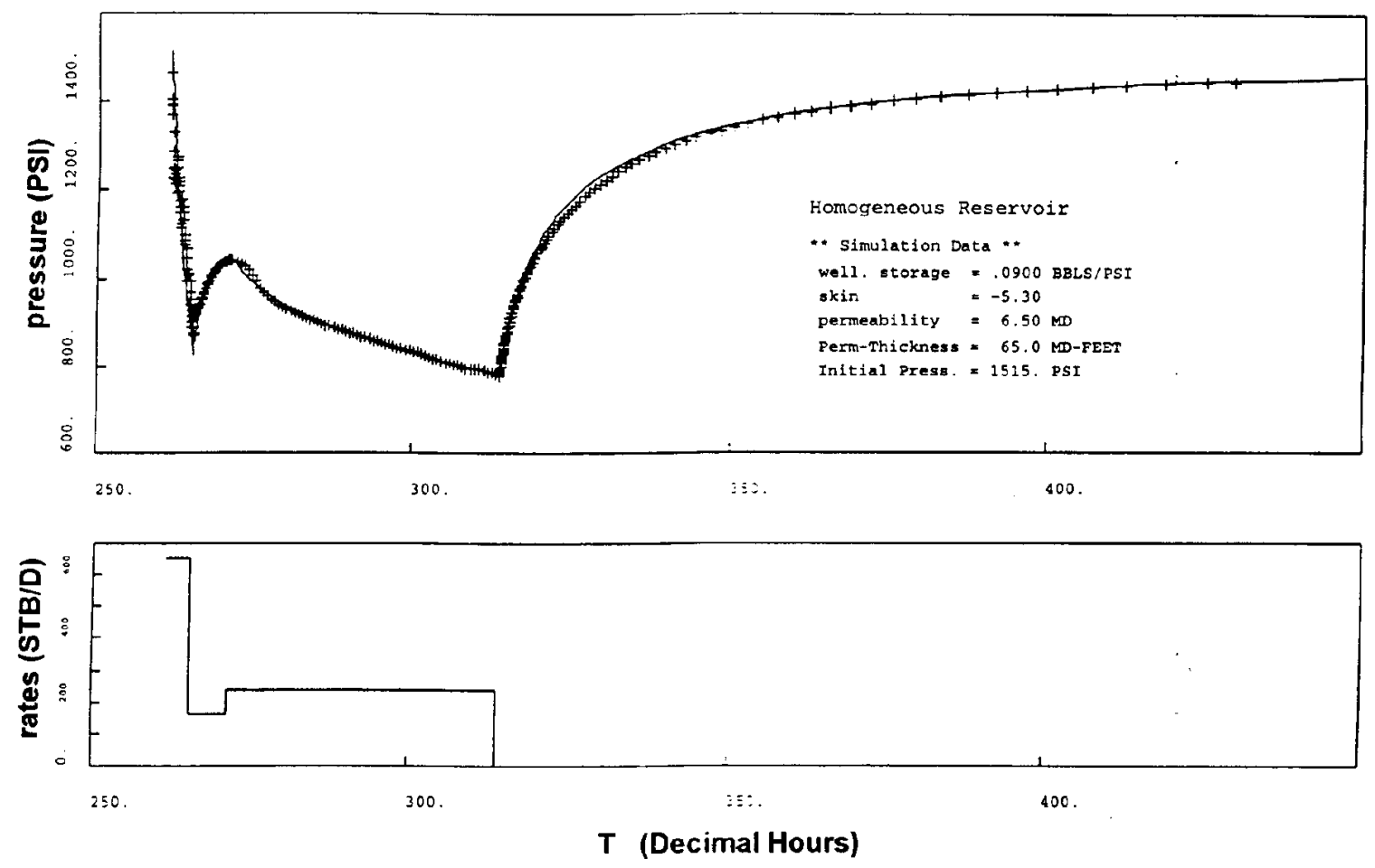

Figure 8-4. Well-flow buildup test analysis of the Big Sky No. 6 E well near Clay Hill field (see figure 1-1) displaying pressure vs. time match.

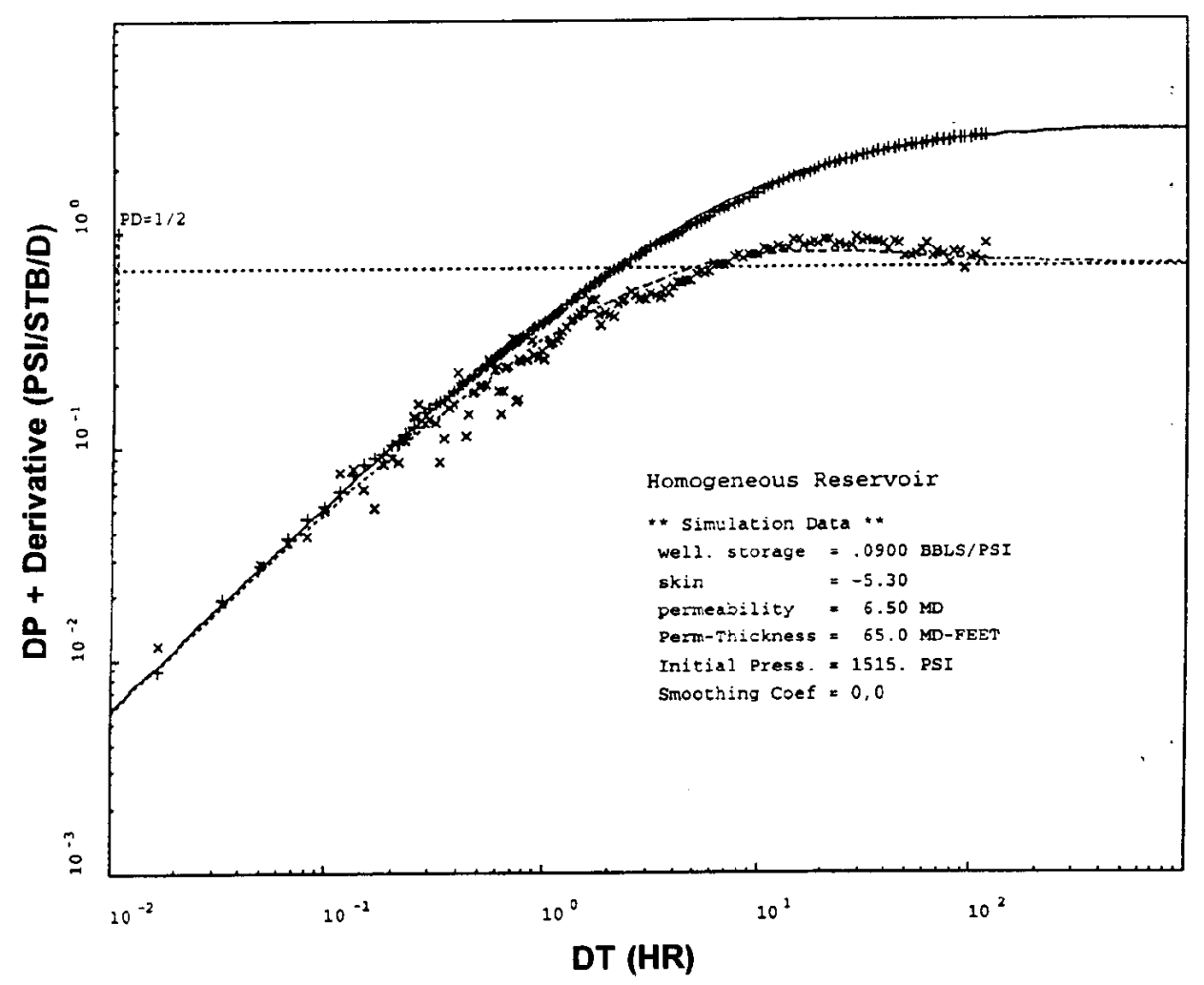

Figure 8-5. Well-flow buildup test analysis of the Big Sky No. 6E well displaying pressure difference and pressure derivative match. 

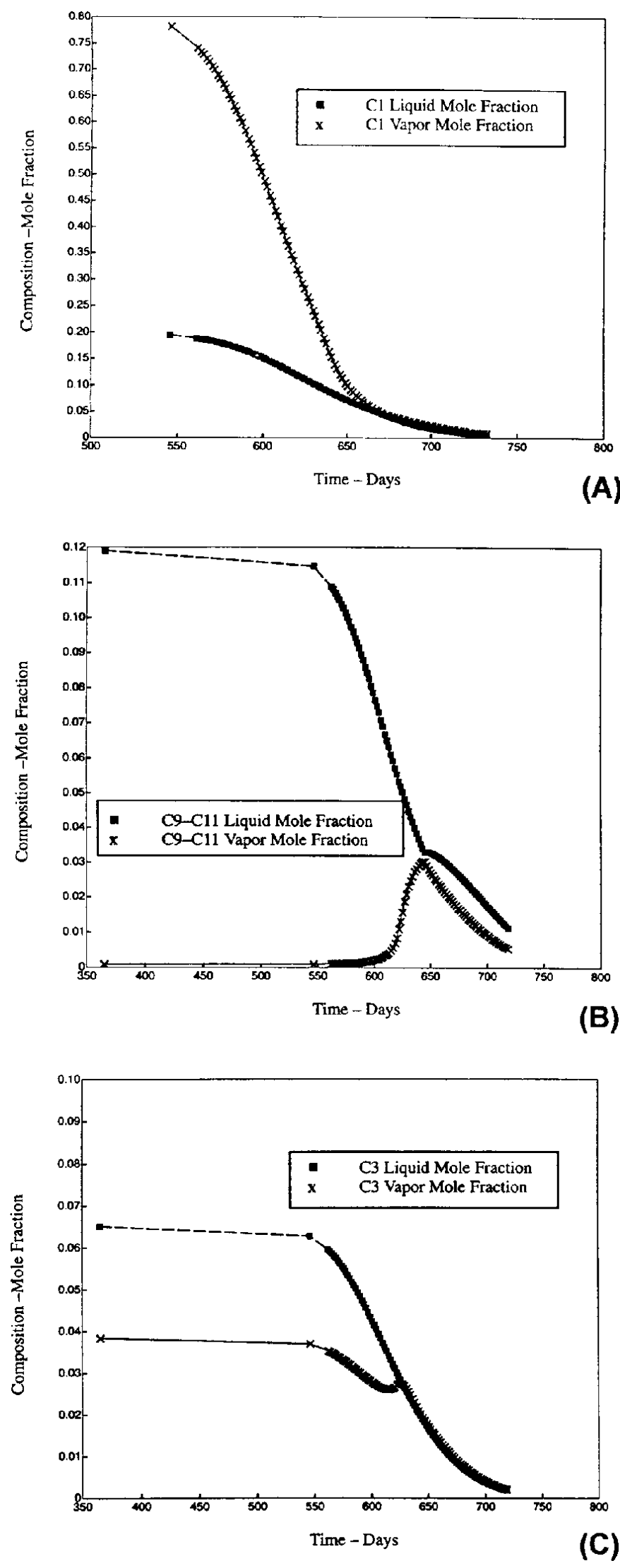

(B)

(C)
Figure 8-6. Variation of composition (mole fraction) of both liquid and vapor phases as a function of time (days) for selected cell in the onedimensional model. (A) $\mathrm{CO}_{2}$ displacement at 3,000 psia; composition versus time for cell 202. (B) $\mathrm{CO}_{2}$ displacement at 2,500 psia; composition versus time for cell 217 component $\mathrm{C} 9$ through $\mathrm{C11}$. (C) $\mathrm{CO}_{2}$ displacement at 2,500 psia; composition versus time for cell 217 component $C 3$. 


\section{History Matching}

The history matching of the primary production phase of Anasazi field was based on one of the geostatistical realizations of the reservoir geologic model. History matching involves the input of historical well/field oil production data with the predicted gas production and reservoir pressure being matched to well/field observed data. Because of the geometric and lithologic complexity of the Anasazi reservoir, a substantial history matching effort was required. A large number of reservoir parameters and reservoir parameter combinations were investigated to match historical gas production and well-to-well and reservoir-to-reservoir (northeast to southwest buildup lobes [figure 3-6]) interaction present during the primary reservoir production phase. Reservoir and fluid properties investigated include many different combinations of these variables:

1. reservoir size/volume,

2. reservoir permeability (both horizontal and vertical) and porosity and their distribution areally as well as between the two principal reservoir facies,

3. gas relative permeability,

4. solution gas content of the original reservoir fluid,

5. rock compressibility,

6. volume of different reservoir facies,

7. transmissibility between the principal mound-core (limestone) and supra-mound (dolomite) intervals, and

8. the use of reservoir unit barriers or transmissibility reduction areas.

No local (near the wellbore) changes were employed to match production. Reservoir description changes on a regional basis were used to match the reservoir-wide fluid movement occurring within the system that in turn controlled local well behavior. Figures 8-7 and 8-8 present oil and gas production data from one of the history match runs. Simulation data are represented by solid curves, and the actual field production by discrete points. Figure 8-9 presents the gas saturation distribution in the reservoir for this run at December 31, 1996. Notice the segregation and accumulation of gas in the upper supra-mound interval while the lower mound-core interval remains oil saturated. Figure 8-10 presents the pressure distribution for the same time point in the simulation. Note the depressurization of the southwest and northeast lobes with the off-flank areas at higher pressure. The key reservoir description changes required to achieve this match are presented below.

1. A substantial reduction of the pore volume of the producing element of the northeast lobe of the buildup. This was accomplished by partitioning the north and south areas of the mound. 


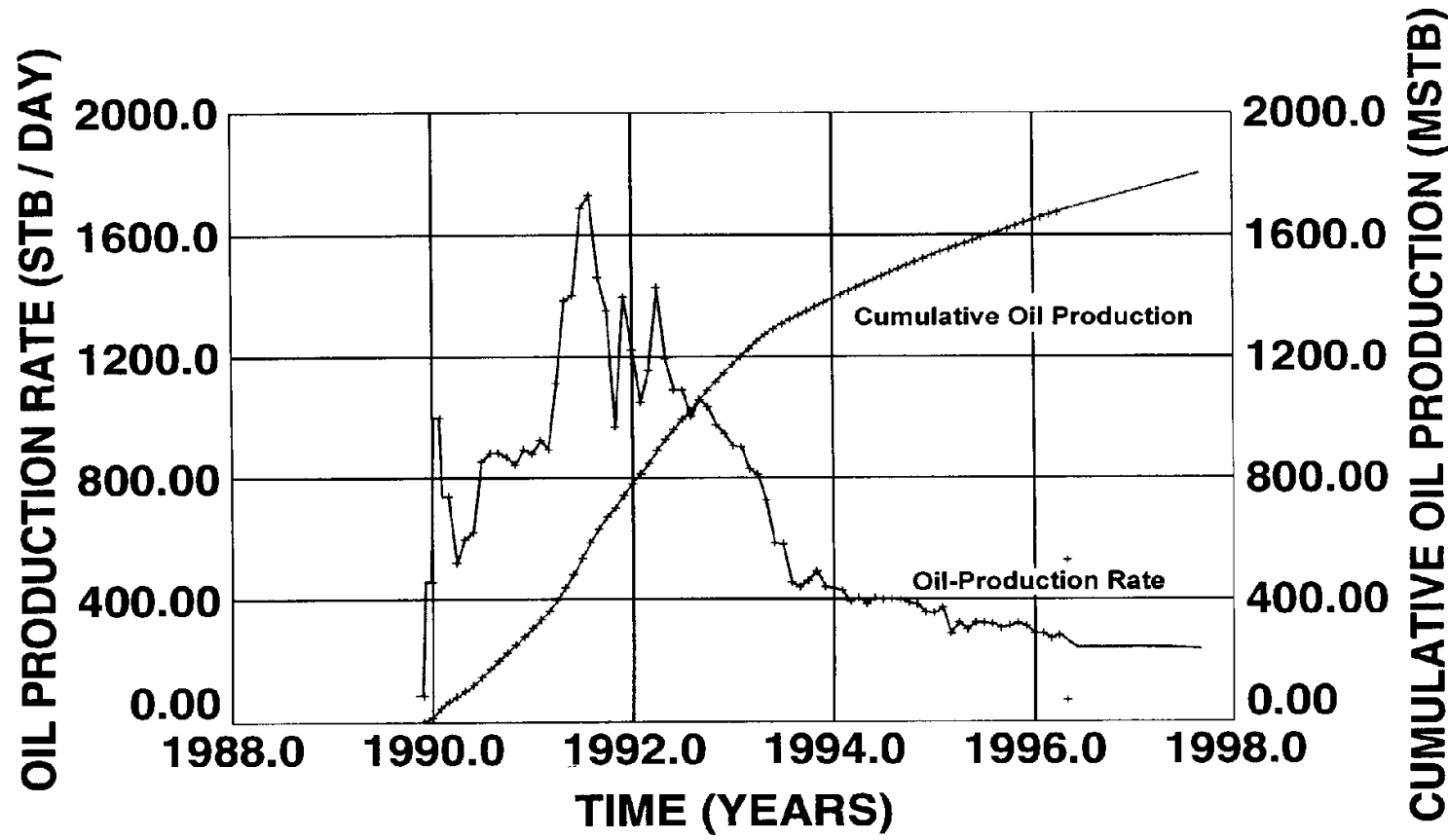

Figure 8-7. Anasazi field oil production rate and cumulative oil production vs. time from history match runs of the two-dimensional reservoir simulation. Simulation data is represented by solid curves and the actual field production by discrete points.

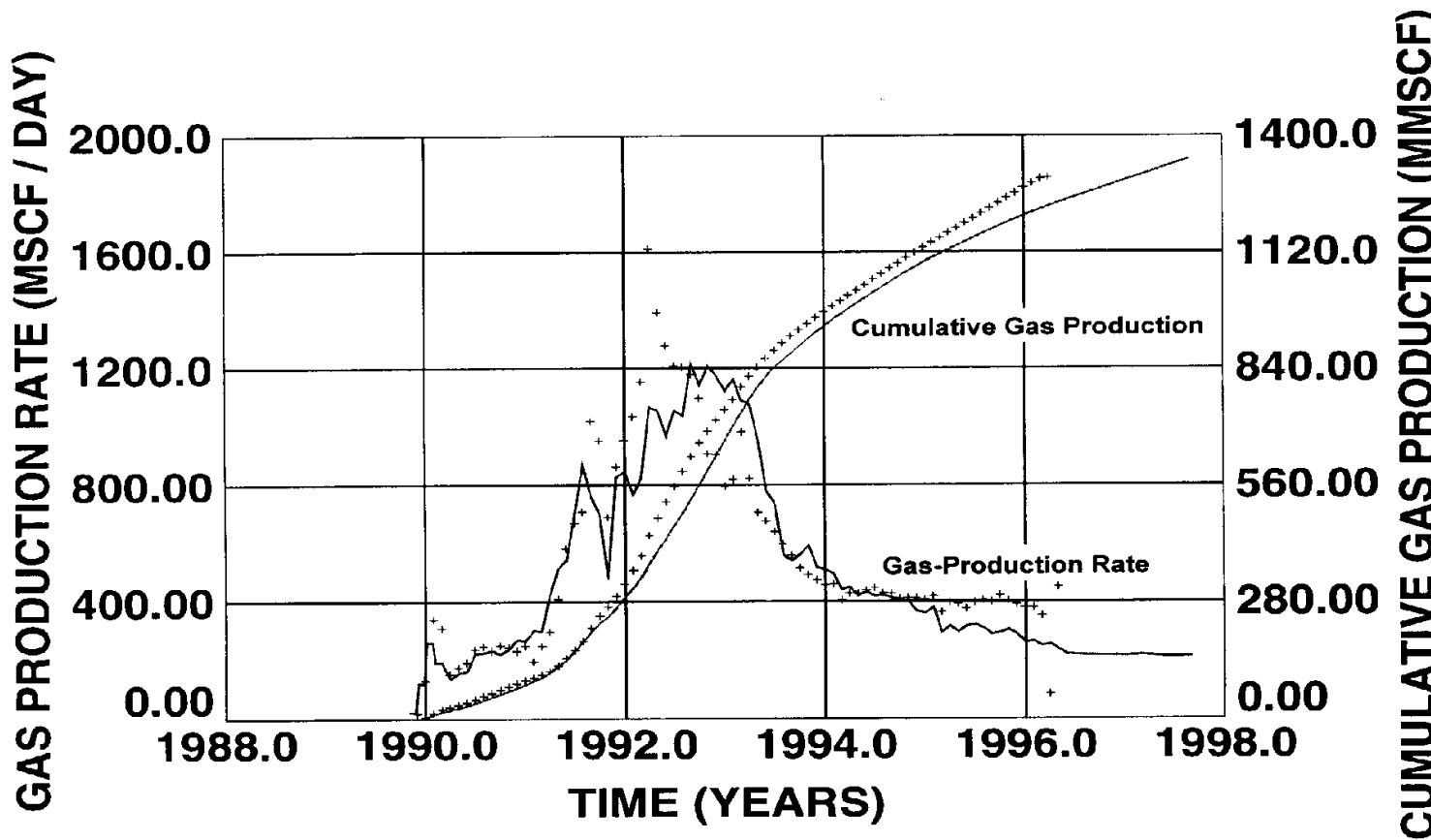

Figure 8-8. Anasazi field gas production rate and predicted cumulative gas production vs. time from history match runs of the two-dimensional reservoir simulation. Simulation data is represented by solid curves and the actual field production by discrete points. 


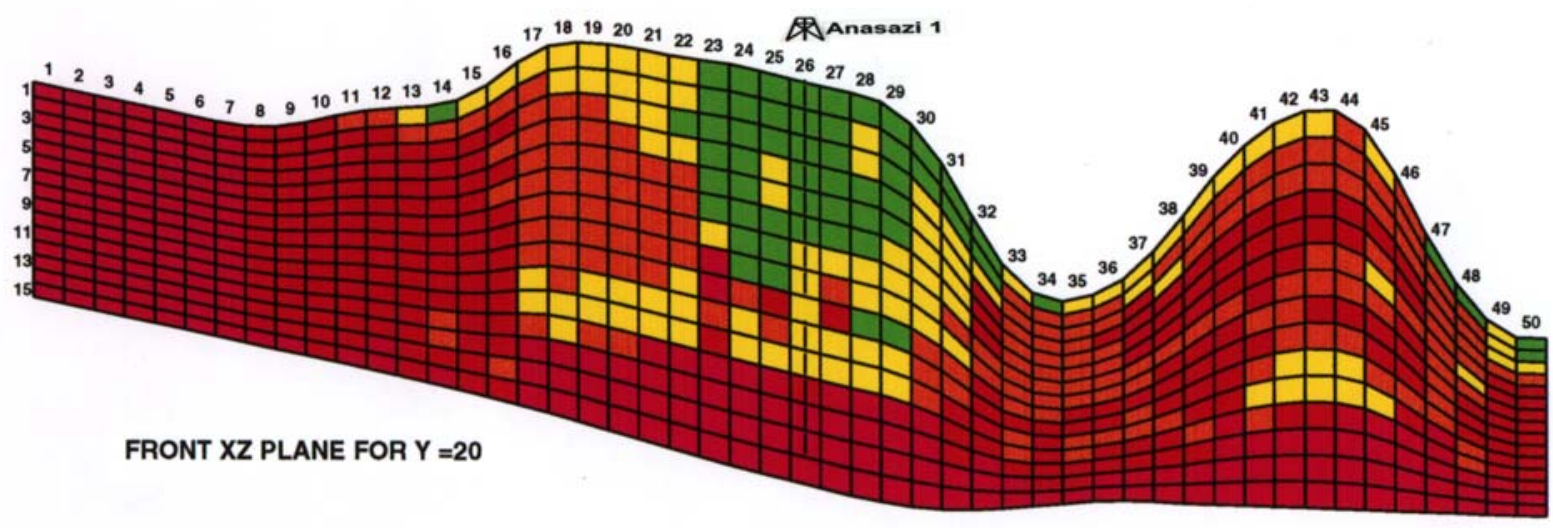

0.0

Figure 8-9. Cross section, through the Anasazi No. 1 well, of the Anasazi reservoir gridsystem model illustrating gas saturation distribution as of December 31, 1996. The model uses 15 stratigraphic layers (z axis) and 50 cells (x axis).

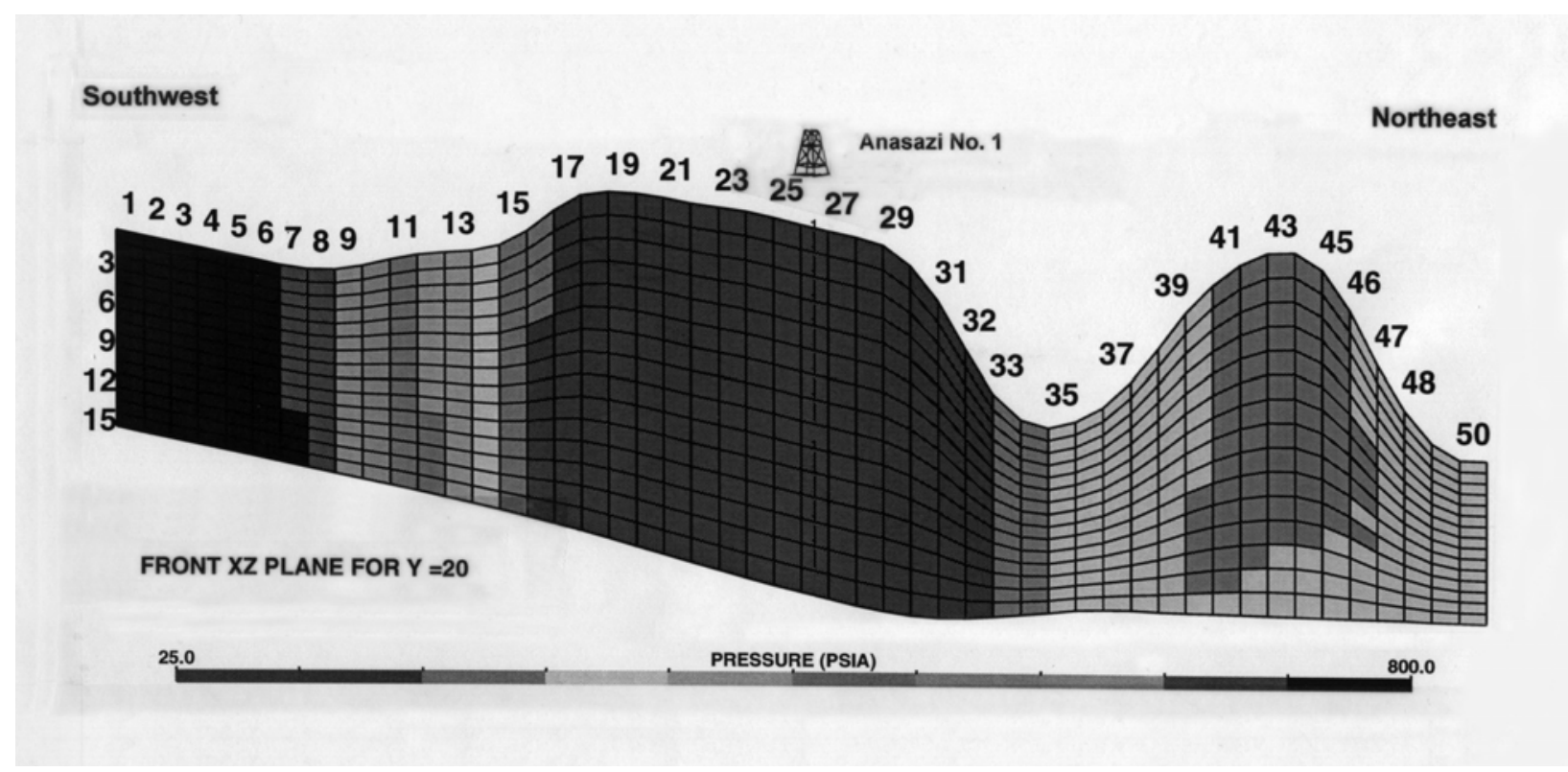

Figure 8-10. Cross section, through the Anasazi No. 1 well, of the Anasazi reservoir gridsystem model illustrating reservoir pressure distribution as of December 31, 1996. 
2. Partial isolation of the drainage volumes associated with the Anasazi No. 1 and Anasazi No. 5L-3 wells (see figure 3-6 for well locations). This was accomplished by the introduction of a transmissibility reduction approximately midway between the two wells.

3. A reservoir volume expansion south and west of the Anasazi No. 5L-3 well.

4. A reduction in vertical permeability of the supra-mound interval overlying the reservoir mound-core interval in the southwest lobe of the buildup.

5. A reduction of the initial solution gas-oil ratio from that reported in the initial reservoir fluid sample analysis. This was required to better match the field observed producing gas-oil ratio prior to the reservoir pressure decreasing below the bubble point pressure (liquid expansion phase of the primary production period).

\section{Reservoir Performance Prediction Studies Using $\mathrm{CO}_{2}$ Injection}

Compositional simulation was used to history match the past production performance of the Anasazi field, and predict the performance of continued primary depletion and various $\mathrm{CO}_{2}$ floods. The simulation study employed a stochastically generated reservoir description employing 12 different facies. The reservoir fluid was characterized via an 11-pseudocomponent equation of state calibrated using $\mathrm{CO}_{2}$ swelling tests conducted on Anasazi crude oil and the original black-oil PVT data. The past production performance was history matched using production history data from the wells in the field. Key history match variables included individual well and field gas production rates, and periodically measured reservoir pressure values. Once the simulator was calibrated by obtaining a suitable match of production data, it was used to predict the performance of the reservoir under continued primary production and $\mathrm{CO}_{2}$-flood operations.

Various $\mathrm{CO}_{2}$-flood operating conditions, injection well placement, and configurations were investigated. Carbon dioxide-flood performance predictions for several different operating conditions and well configurations were completed. Figure 8-11 compares primary depletion performance versus $\mathrm{CO}_{2}$ flooding. For this example, the incremental oil recovery over primary production at January 1, 2011 is about 2.0 MMSTB $\left(318,000 \mathrm{~m}^{3}\right)$. Figure 8-12 illustrates the predicted oil saturation at the start of $\mathrm{CO}_{2}$ injection. Six years of primary production has generated a variable free-gas saturation, 0 to 40 percent, as well as producing 1.75 MMSTB $\left(278,250 \mathrm{~m}^{3}\right)$ of oil. The simulator predicts extensive gas segregation into the supra-mound interval.

The oil saturation after 10 years of $\mathrm{CO}_{2}$ injection via two injector wells, one located in the southwest lobe and the other in the northeast lobe of the buildup, is shown in figure 8-13. The figure illustrates two important points: (1) reservoir pressurization redissolves all the free hydrocarbon gas present at the start of injection, returning the majority of the reservoir to initial oil saturation values, and (2) the volume of the reservoir contacted by the injected $\mathrm{CO}_{2}$ shows a near zero residual oil saturation. This displaced oil is produced via existing producers. Both the supra-mound and mound-core intervals have been swept by $\mathrm{CO}_{2}$. The liquid phase, mole fraction of $\mathrm{CO}_{2}$ indicates extensive contact of reservoir volume by $\mathrm{CO}_{2}$. At the operating 


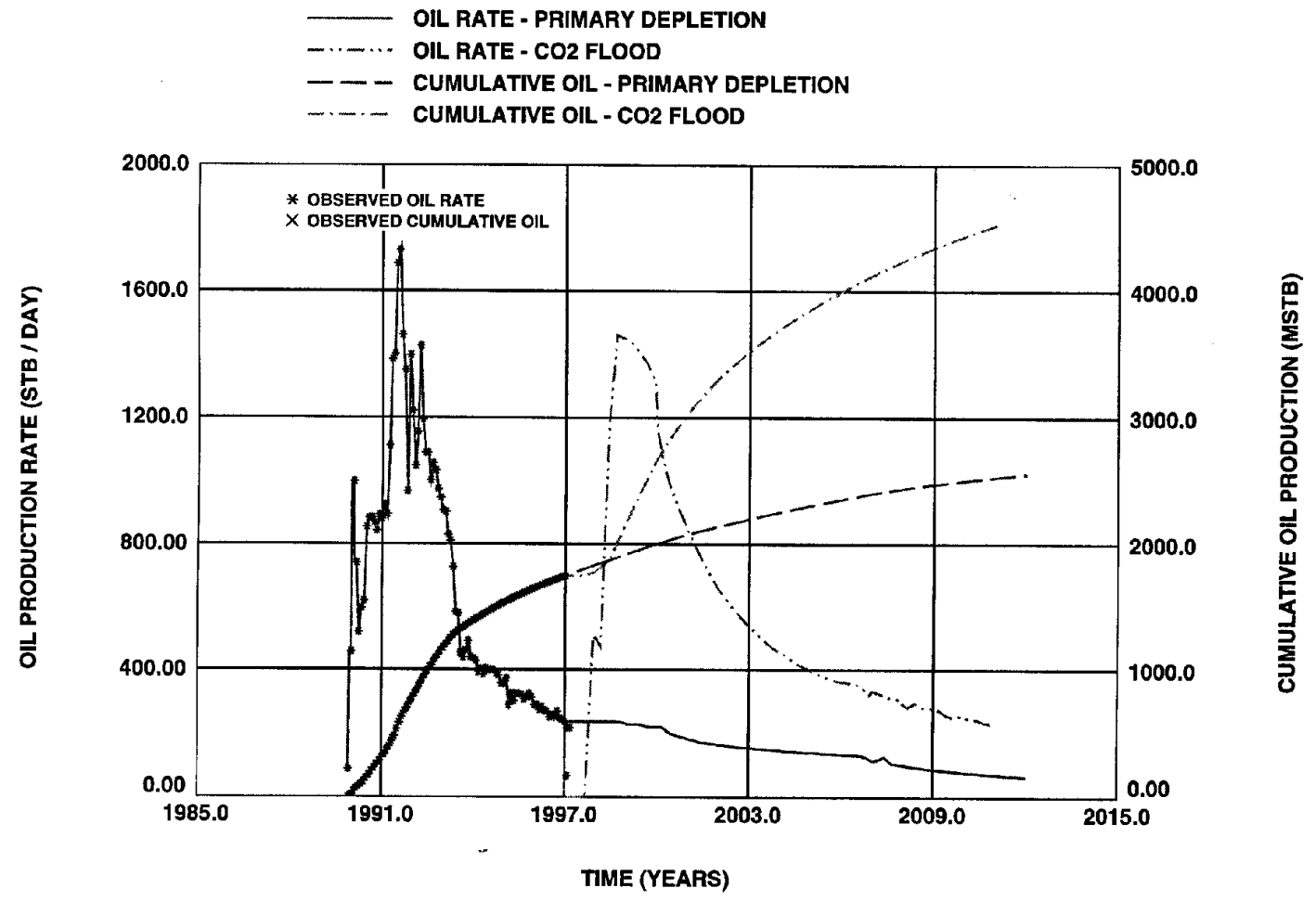

Figure 8-11. Anasazi field oil-production rate and cumulative oil production comparing primary depletion and $\mathrm{CO}_{2}$ flooding vs. time.

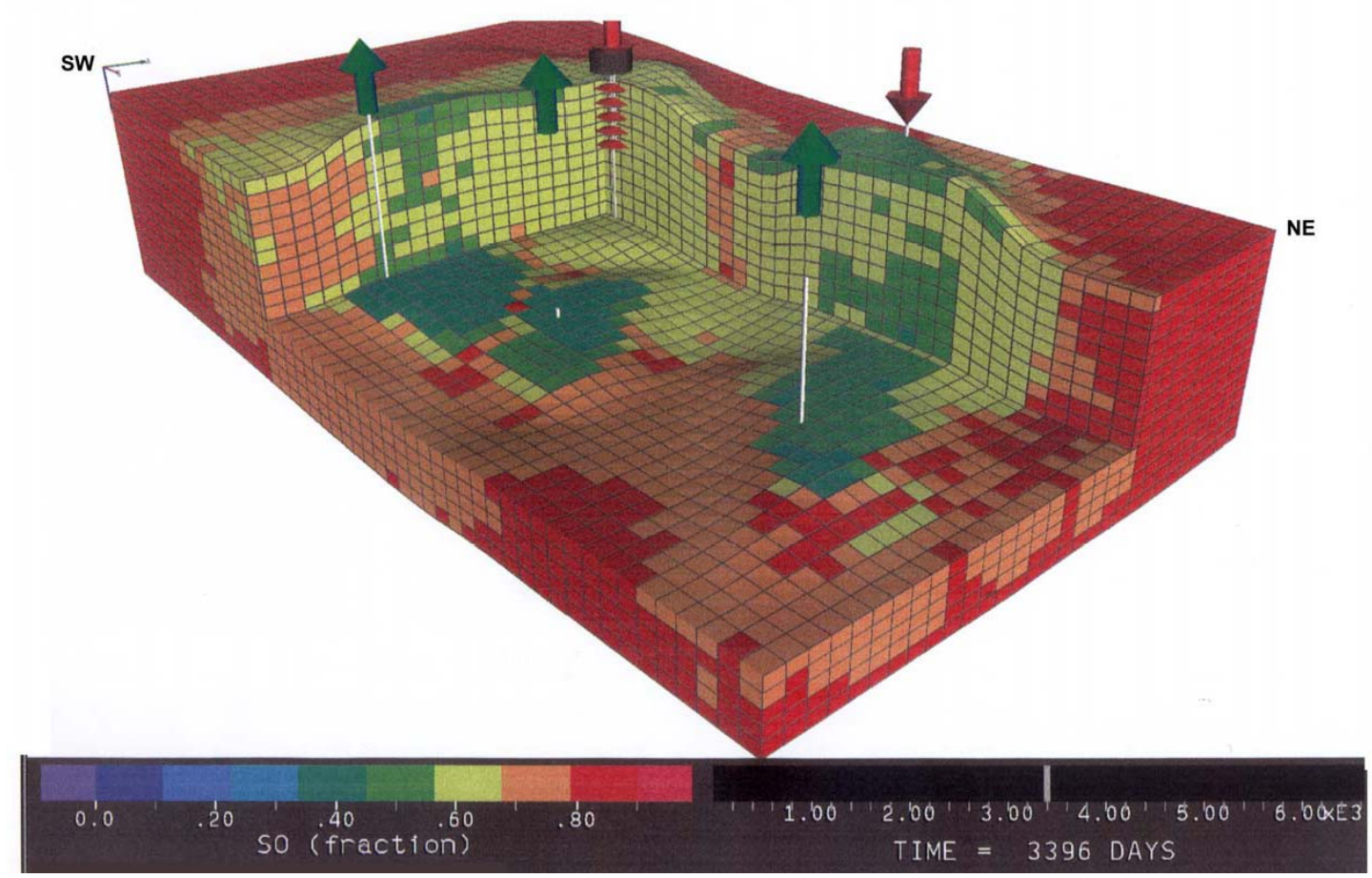

Figure 8-12. Block diagram displaying reservoir oil saturation at the start of $\mathrm{CO}_{2}$ injection (January 1, 1997). Shown is a "cut away" through one of the proposed $\mathrm{CO}_{2}$ injectors at the Anasazi No. 6H-1 well location and the Anasazi No. $5 \mathrm{~L}-3$ well location. 


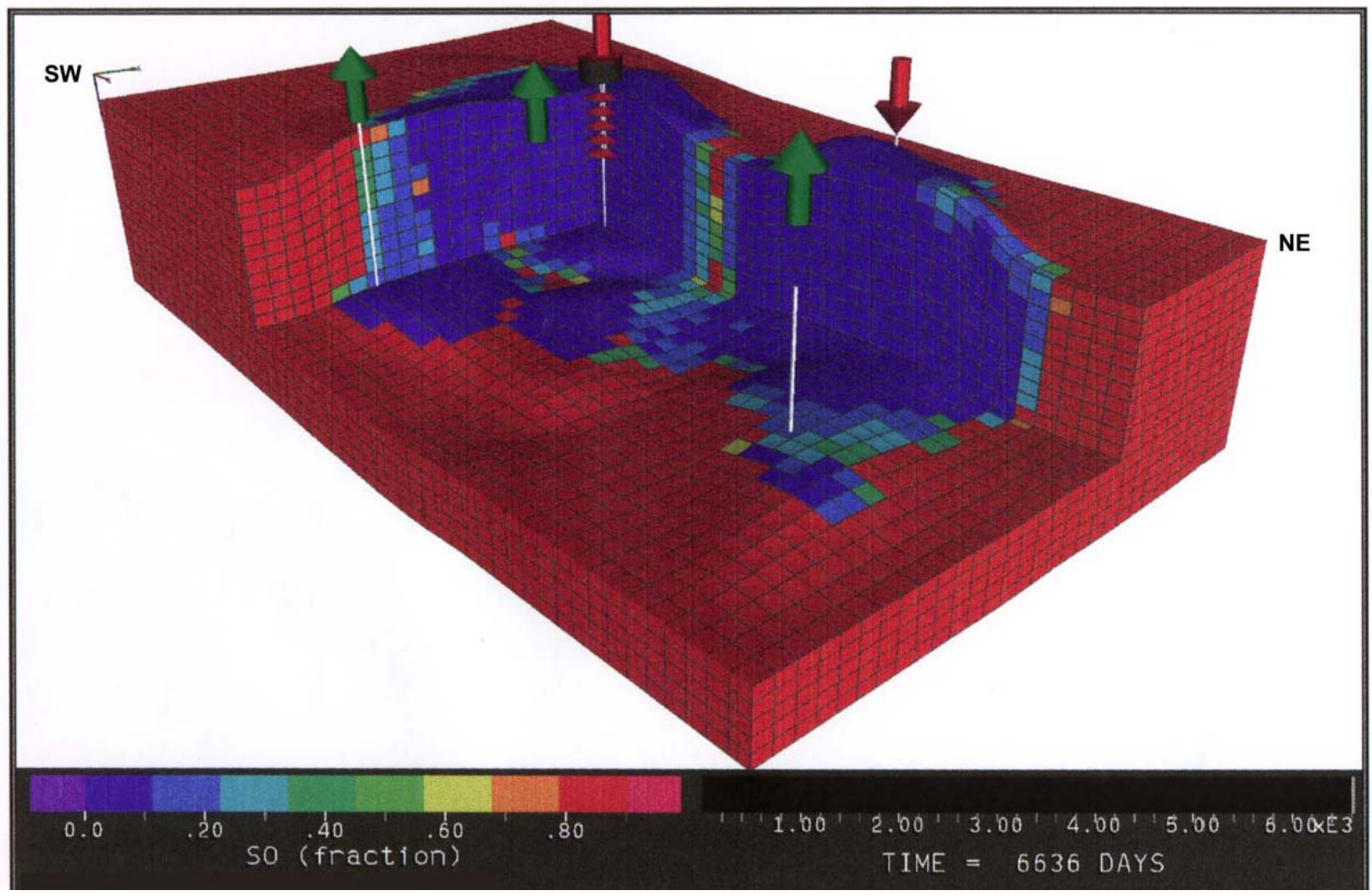

Figure 8-13. Block diagram displaying reservoir oil saturation after 10 years of $\mathrm{CO}_{2}$ injection (January 1, 2008).

pressure level of 2,000 to 3,000 psi (13,790-20,685 Kpa), $\mathrm{CO}_{2}$ and hydrocarbons are at, or near, miscible conditions. Thus, the oil displacement will be essentially complete (low residual oil saturation values).

Upon completion of the history match of the primary production phase of the Anasazi field, a series of $\mathrm{CO}_{2}$-flood cases were completed. This series of cases accomplished the following:

- identified the required $\mathrm{CO}_{2}$-flood, operating pressure to obtain process miscibility,

- $\quad$ identified the optimum location for two $\mathrm{CO}_{2}$ injector wells based on the current reservoir description,

- $\quad$ quantified the reservoir performance and economic impact of removing hydrocarbon gases from the produced gas stream and re-injection of $\mathrm{CO}_{2}$ versus re-injection of unprocessed produced gas $\left(\mathrm{CO}_{2}\right.$ plus hydrocarbon components),

- $\quad$ evaluated the use of horizontal injection wells versus vertical ones, and

- $\quad$ quantified the performance of a process combining $\mathrm{CO}_{2}$ injection followed by reservoir blow down. 
Figure 8-14 compares oil recovery through the year 2012 from continued primary production to recovery via continuous $\mathrm{CO}_{2}$ injection. The incremental oil recovery for the $\mathrm{CO}_{2}$ flood versus primary production is approximately $2.5 \mathrm{MMSTB}\left(397,500 \mathrm{~m}^{3}\right)$ of oil. Recovery of this additional oil required purchase of $12.0 \mathrm{BCF}\left(0.34\right.$ billion $\left.\mathrm{m}^{3}\right)$ of $\mathrm{CO}_{2}$ plus injection of produced gas.

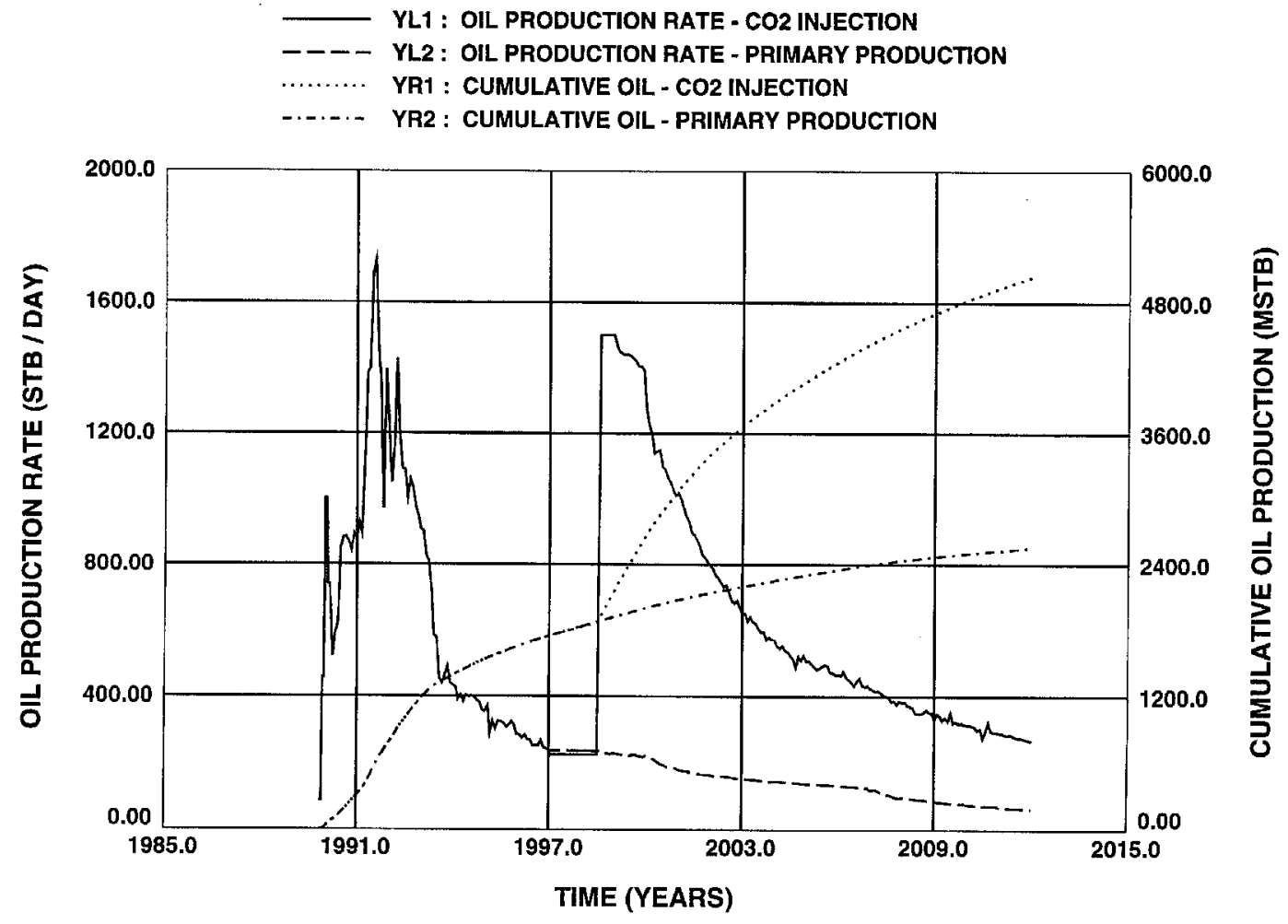

Figure 8-14. Oil recovery - primary versus continuous $\mathrm{CO}_{2}$ injection, Anasazi field.

Two additional simulation prediction cases (A and $B$ ) serve as the basis for the economic assessment of $\mathrm{CO}_{2}$ flooding (see Chapter IX, Economic Assessments of $\mathrm{CO}_{2}$ Floods and Recommendations). The principal operating parameters and simulation-related data used for these simulation cases were:

- $\quad \mathrm{CO}_{2}$ injection starts on January 1, 2000 (the simulation studies were conducted in 1997 and designed for a field demonstration which was to have begun in the year 2000).

- $\quad$ Simulation case A uses an injection rate of 2.0 million standard cubic feet of gas per day (MMSCFGPD [56,640 $\left.\mathrm{m}^{3} / \mathrm{d}\right]$ )/well and case $\mathrm{B}$ uses an injection rate of 4.0 MMSCFGPD $\left(113,280 \mathrm{~m}^{3} / \mathrm{d}\right) /$ well. Injection was simulated through one well in each of the two mound lobes (figure 3-6). 
- $\quad$ Production wells Anasazi No. 1, Anasazi No. 5L-3, and Sahgzie No. 1 (figure 36) were allowed to produce at the rate in effect on January 1, 2000 during reservoir fill-up.

- $\quad$ Produced gas was recycled to reduce $\mathrm{CO}_{2}$ make-up gas purchases. Thus, no conditioning was employed.

- $\quad \mathrm{CO}_{2}$ injection was continuous from the start of injection until January 1, 2012.

Table 8-2 summarizes relevant production/injection data for simulation prediction cases $\mathrm{A}$ and $\mathrm{B}$. The data show that for case A, the incremental oil recovery above primary was 951,000 bbls $\left(151,209 \mathrm{~m}^{3}\right)$ at January 1,2012 . This required injection of 17.5 billion standard cubic feet (BSCF [0.5 billion $\left.\mathrm{m}^{3}\right]$ ) of $\mathrm{CO}_{2}$ and produced gas, and purchase of $10.1 \mathrm{BSCF}(0.29$ billion $\mathrm{m}^{3}$ ) of $\mathrm{CO}_{2}$. Simulation prediction results indicate that a $\mathrm{CO}_{2}$ injection rate of 2.0 MMSCFGPD $\left(56,640 \mathrm{~m}^{3} / \mathrm{d}\right) /$ well would not be sufficient to meet ongoing production needs of the operator and generate acceptable economic returns. It would however, increase recovery by close to 1.0 MMSTB $\left(159,000 \mathrm{~m}^{3}\right)$ of oil over predicted primary recovery at January 1, 2012.

Table 8-2. Production/injection data for $\mathrm{CO}_{2}$ flood, Anasazi field.

\begin{tabular}{|c|c|c|c|c|c|c|}
\hline Case & $\begin{array}{l}\text { Cum Oil } \\
\text { (MSTB) }\end{array}$ & $\begin{array}{c}\text { Cum Gas } \\
\text { (BSCF) }\end{array}$ & $\begin{array}{l}\text { Incremental over } \\
\text { Primary (MSTB) }\end{array}$ & $\begin{array}{l}\text { Total Gas Inj. } \\
\text { (BSCF) }\end{array}$ & $\begin{array}{c}\text { Total } \mathrm{CO}_{2} \\
\text { Purchase } \\
\text { (BSCF) }\end{array}$ & \begin{tabular}{|c|} 
Total Gas \\
Recycled \\
(BSCF) \\
\end{tabular} \\
\hline \multicolumn{7}{|c|}{ Production / Injection at January 1, 2003} \\
\hline A & 2116 & 1.7 & -78 & 4.4 & 4.2 & 0.2 \\
\hline B & 2293 & 2.6 & 99 & 8.8 & 7.8 & 1.0 \\
\hline \multicolumn{7}{|c|}{ Production / Injection at January 1, 2006} \\
\hline A & 2385 & 2.4 & -7 & 8.8 & 8.0 & 0.8 \\
\hline B & 3302 & 9.4 & 910 & 17.5 & 9.8 & 7.7 \\
\hline \multicolumn{7}{|c|}{ Production / Injection at January 1, 2012} \\
\hline A & 3505 & 9.1 & 951 & 17.5 & 10.1 & 7.4 \\
\hline B & 4208 & 25.2 & 1654 & 35.0 & 11.5 & 23.5 \\
\hline
\end{tabular}

The data shows that for case $\mathrm{B}$, the incremental oil recovery above primary was $1,654,000 \mathrm{bbls}\left(262,986 \mathrm{~m}^{3}\right)$ at January 1,2012 . This required injection of $35.0 \mathrm{BSCF}(1.0$ billion $\left.\mathrm{m}^{3}\right)$ of $\mathrm{CO}_{2}$ and produced gas, and purchase of $11.5 \mathrm{BSCF}\left(0.33\right.$ billion $\left.\mathrm{m}^{3}\right)$ of $\mathrm{CO}_{2}$. Specifically, using a 4.0 MMSCFGPD $\left(113,280 \mathrm{~m}^{3} / \mathrm{d}\right) /$ well injection rate from two injectors, the $\mathrm{CO}_{2}$ flood will recovery 4.21 MMSTB $\left(669,390 \mathrm{~m}^{3}\right)$. This represents an increase of 1.65 MMSTB $\left(262,350 \mathrm{~m}^{3}\right)$ over predicted primary recovery at January 1,2012 . The projected 4.21 MMSTB $\left(669,390 \mathrm{~m}^{3}\right)$ represents more than 89 percent of the oil in the mound complex and 36.8 percent of the original oil in place in the total modeled system. 


\section{Reservoir Performance Prediction Studies Using Water Injection}

The series of waterflood predictions assessed the placement and completion configuration of injection wells, and the use of horizontal injector wells versus vertical injector wells.

In general, injection of water had a detrimental effect on continued production during reservoir fill up. Waterfloods recovered less oil than primary production through the year 2012. If waterflood operations were carried out past the year 2012, oil recovery could exceed primary, but ultimate recovery was significantly less than $\mathrm{CO}_{2}$ with the additional expense of operating a waterflood for an additional 10 years past the year 2012. Figure 8-15 illustrates one of the waterflood prediction cases versus primary production. At the year 2008 (after 12 years of water injection), oil recovery was approximately 270,000 stock tank barrels (STB [42,930 $\left.\mathrm{m}^{3}\right]$ ) less than primary. At the year 2012 waterflooding, still had recovered less than primary $\left(20,000 \mathrm{STB}\left[3,180 \mathrm{~m}^{3}\right]\right)$ and approximately $2.5 \operatorname{MMSTB}\left(397,500 \mathrm{~m}^{3}\right)$ less than $\mathrm{CO}_{2}$ flooding. The poor performance of waterflooding is attributable to the low injectivity of water, and the water's interference with oil migration into the mound-core interval from from both the supramound interval and off-mound area.
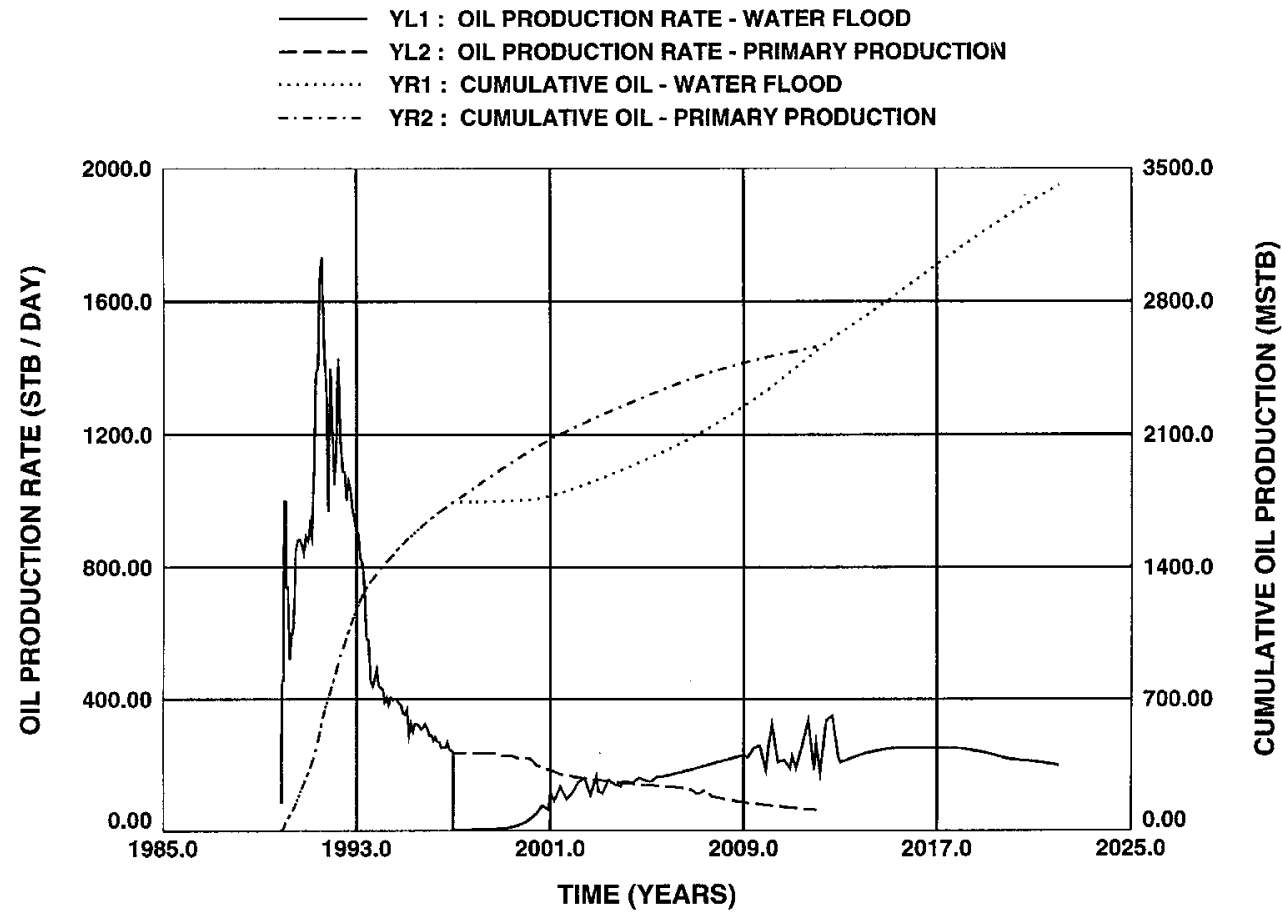

Figure 8-15. Oil recovery - primary versus waterflood, Anasazi field.

\section{Reservoir Simulation: Runway Field}

Compositional simulation was used to history match (model) predicted production to actual past production performance of the Runway field, and to predict the performance of continued primary depletion and various $\mathrm{CO}_{2}$ floods. The simulation study employed a stochastically generated reservoir description with 12 different facies. The reservoir fluid was 
characterized via an 11-pseudo-component equation of state calibrated using $\mathrm{CO}_{2}$-swelling tests conducted on crude oil from Anasazi field and the original black-oil PVT data for Runway field (Lorenz and others, 1998). Gas-oil and water-oil relative permeability, capillary pressure, and rockpore volume compressibility data were generated for the three principal productive facies: phylloid-algal limestone, enhanced-porosity packstones/wackestones, and bryozoan limestone.

\section{History Matching}

The history matching of the primary production phase of Runway field was also based on one of the geostatistical realizations of the reservoir geologic model. Reservoir and fluid properties investigated included many different combinations of the same variables used for Anasazi field. Key history match variables included individual well and field-wide gas production rates, and periodically measured reservoir pressure values. Once the simulator was calibrated by obtaining a suitable match of production data, it was used to predict the performance of the reservoir under continued primary production as well as $\mathrm{CO}_{2}$-flood operations.

\section{Reservoir Performance Prediction Studies Using $\mathrm{CO}_{2}$ Injection}

Carbon-dioxide flood performance predictions for several different operating conditions and well configurations were completed. Figure 8-16 compares primary depletion performance versus $\mathrm{CO}_{2}$ flooding using two horizontal injection wells. For this example, the incremental oil recovery over primary at January 1,2012 is approximately $1.34 \operatorname{MMSTB}\left(0.21\right.$ million $\left.\mathrm{m}^{3}\right)$.

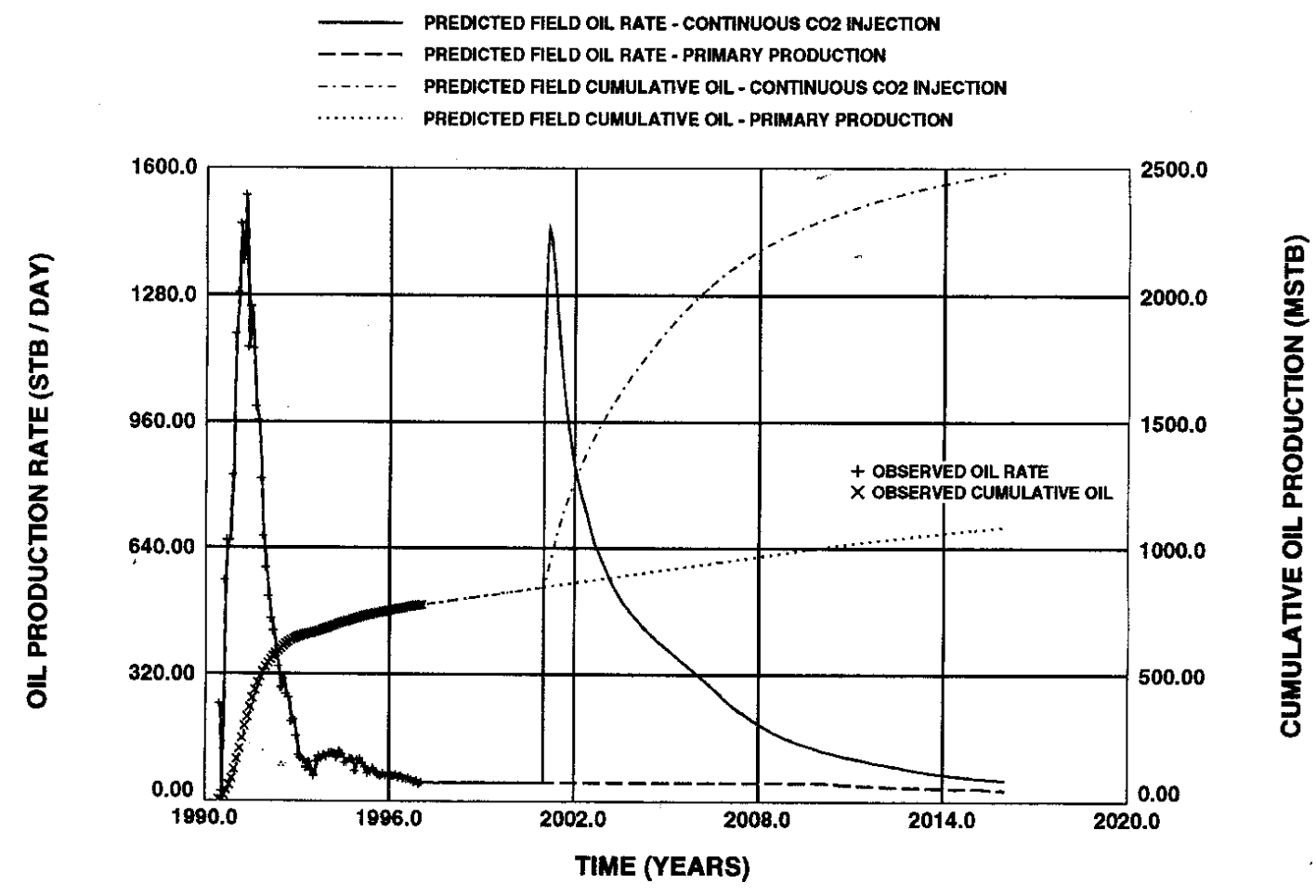

Figure 8-16. Oil recovery - primary depletion versus continuous $\mathrm{CO}_{2}$ flood injection/flood recovery, Runway field. 
Oil and gas saturations were modeled for the start of $\mathrm{CO}_{2}$ injection. Ten years of primary production has generated a variable free gas saturation ( 0 to 40 percent) as well as producing $825,000 \mathrm{STB}\left(131,175 \mathrm{~m}^{3}\right)$ of oil. The simulator model also shows extensive gas segregation into the supra-mound interval.

Figure 8-17 illustrates the oil saturation distribution in the Ismay (upper layer) and Desert Creek (lower layer) zones at the start of $\mathrm{CO}_{2}$ injection, based on a "cut away" through the Runway Nos. 10G-1 and 10E-2 production wells (also see figure 3-10 for well locations). The two injectors (shown in figure 8-17 as three-dimensional arrows pointing downward) are horizontal wells, but the horizontal leg of each well is hidden from view. The upper-most injector is placed along the northwestern flank of the mound, and the lower-most injector is placed along the southeastern flank of the mound. Both injectors were completed in the supramound interval.

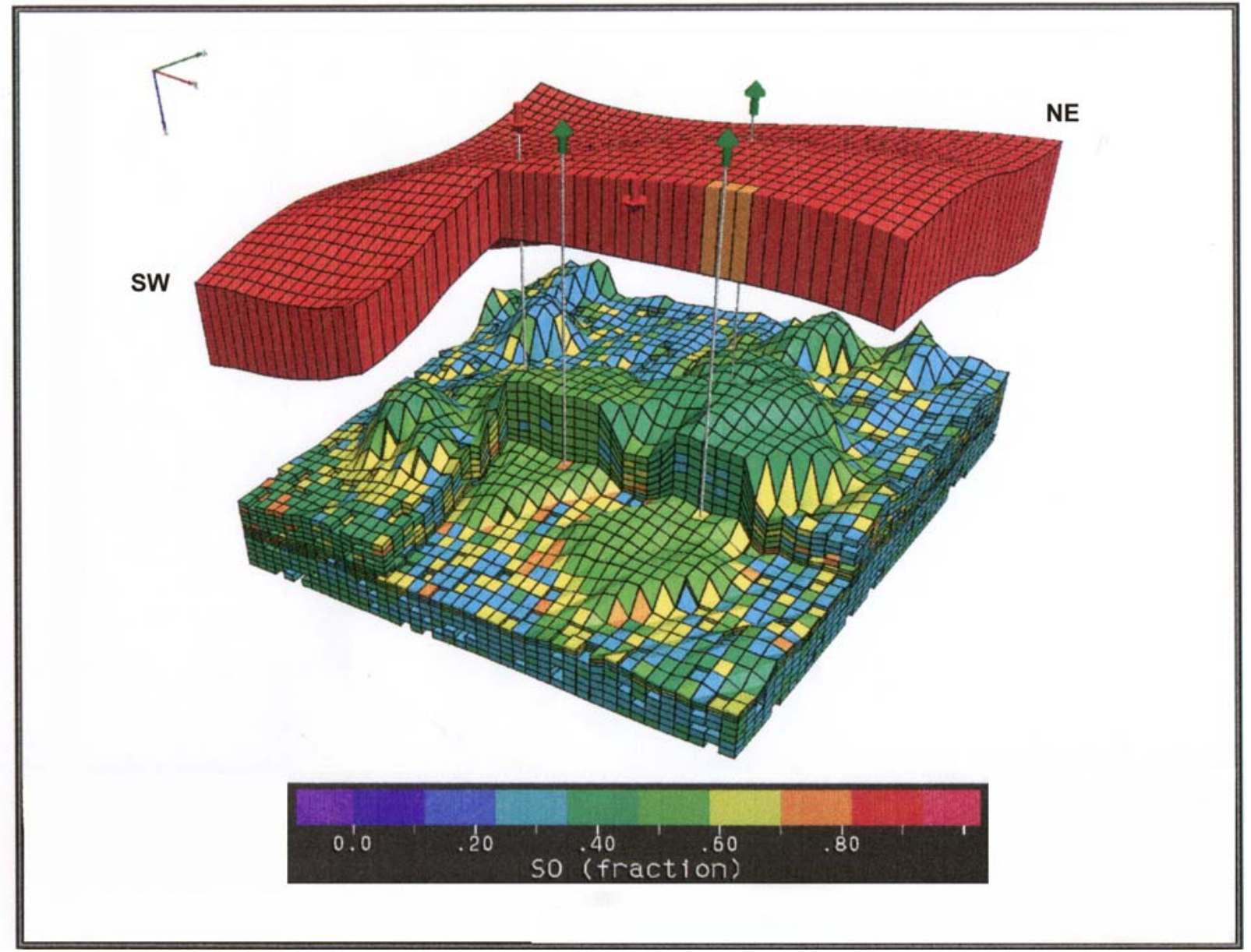

Figure 8-17. Block diagram displaying reservoir oil saturation distribution at the start of $\mathrm{CO}_{2}$ injection. Shown is a "cut away" through one of the proposed horizontal injector wells and the Runway Nos. 10G-1 and 10E-2 production well locations. SO (fraction) is the oil saturation. 
Figure 8-18 illustrates the oil saturation distribution after 4.5 years of $\mathrm{CO}_{2}$ injection using two injectors. The figure shows two important points. First, reservoir pressurization redissolves all free hydrocarbon gas present at the start of injection, returning the majority of the reservoir to initial oil saturation values. Second, the volume of the reservoir contacted by the injected $\mathrm{CO}_{2}$ shows a near-zero, residual oil saturation. This displaced oil is produced via the existing field production wells. Both the supra-mound and mound-core intervals have been swept by $\mathrm{CO}_{2}$, but there is an uncontacted portion of the reservoir between the Runway Nos. 10G-1 and 10C-5A wells. This area will be swept after additional $\mathrm{CO}_{2}$ injection based on the simulation. The study also shows the extensive contact of reservoir volume by $\mathrm{CO}_{2}$ (liquid phase mole fraction of $\left.\mathrm{CO}_{2}\right)$ after 4.5 years of $\mathrm{CO}_{2}$ injection. At a 3,000 psi $(20,790 \mathrm{kpa})$ operating pressure level, $\mathrm{CO}_{2}$ and hydrocarbon are at, or near, miscible conditions. Thus, the oil displacement will be essentially complete (low residual oil saturation values).

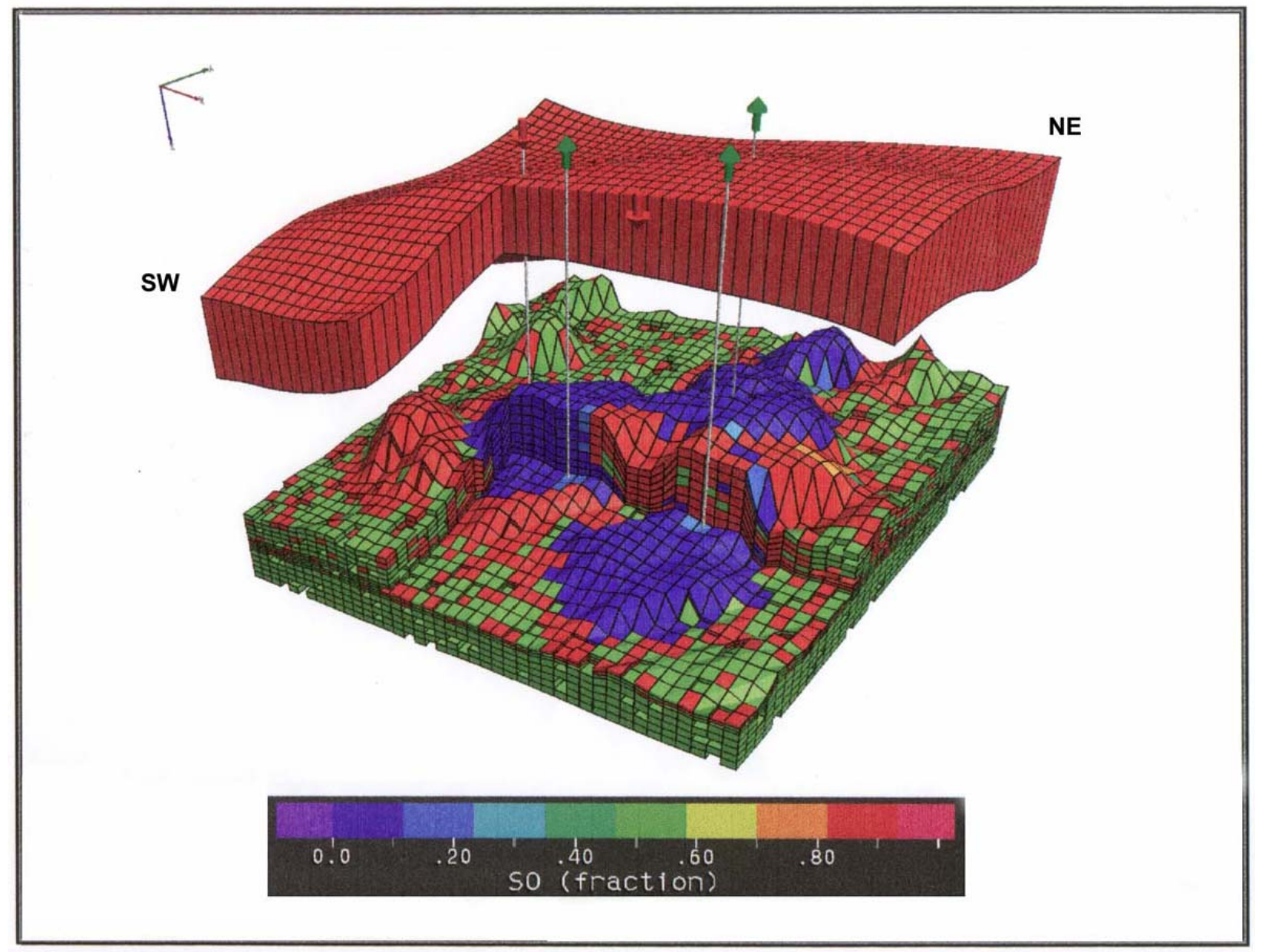

Figure 8-18. Block diagram displaying reservoir oil saturation distribution after 4.5 years of $\mathrm{CO}_{2}$ injection, Runway field. 


\title{
CHAPTER IX \\ ECONOMIC ASSESSMENTS OF RESERVOIR $\mathrm{CO}_{2}$ FLOODS AND RECOMMENDATIONS
}

\author{
William E. Culham and Douglas M. Lorenz \\ REGA Inc.
}

\section{Overview}

The principal objectives of Phase I of the project study were to develop detailed quantitative descriptions of shallow-shelf carbonate buildups (algal mounds) and use these descriptions, coupled with composition simulation, to predict the performance of the reservoirs in the mound complexes for three, different, reservoir-recovery processes. The three processes were: primary depletion, $\mathrm{CO}_{2}$ flooding, and waterflooding. The economic feasibility of implementing one or more recovery processes was also investigated.

The results of the compositional studies conducted for Anasazi and Runway fields indicate that $\mathrm{CO}_{2}$ flooding is the only technically feasible recovery process suitable for these reservoirs. Based on this conclusion, $\mathrm{CO}_{2}$-flood implementation costs were developed. Implementation costs, in conjunction with reservoir performance production and injection predictions, were used in 1998 to complete a suite of economic assessment studies using a startup date in the year 2000. One of the various $\mathrm{CO}_{2}$-implementation options studied provided the best economic return; a continuous $\mathrm{CO}_{2}$-injection case utilizing re-injection of the unprocessed, produced gas, a leased main-injection compressor, and DOE cost share. This option provided a before-tax, net present value (NPV), discounted at 10 percent per year of more than $\$ 12.5$ million and before-tax, rate of return (ROR) of 62 percent on a total investment of $\$ 2.7$ million for Anasazi field. The profitability index (PI) of this particular implementation was determined to be 15 to 1.0. For Runway field, before-tax NPV, discounted at 10 percent per year, would be more than $\$ 3.1$ million, with a before-tax ROR of 30 percent on a total investment of $\$ 2.79$ million. The PI of this particular implementation was determined to be 5.0 to 1.0.

The study results on predicted $\mathrm{CO}_{2}$-flood responses and the associated economics, supported the extension of the overall shallow-shelf carbonate evaluation program to Phase II. Phase II would involve the implementation and completion of a $\mathrm{CO}_{2}$ flood in the Anasazi or Runway reservoirs.

\section{Anasazi Field}

\section{Economic Assessment of $\mathrm{CO}_{2}$ Flood}

Using reservoir-simulation-based performance predictions and current $\mathrm{CO}_{2}$-flood implementation costs, detailed economic assessments were conducted for a number of different $\mathrm{CO}_{2}$-flood options. These sets of studies indicated that:

1. A $\mathrm{CO}_{2}$ flood of the Anasazi reservoir has robust economics. With DOE participation the project would have a ROR of 62 percent, a payout of 35 months, a PI of 15 to 1 , and a discounted (10 percent) NPV in excess of $\$ 12.5$ 
million. Even without DOE participation the economics remain robust with a ROR of 48 percent, a payout of 39 months, a PI of 8 to 1 , and a discounted NPV of over $\$ 11.0$ million. The capital requirements would be $\$ 3.146$ million.

2. Leasing the compressor on a five year contract basis is better economically than purchasing the compressor. Leasing improves the NPV by approximately $\$ 1.0$ million.

3. The benefit from separating $\mathrm{CO}_{2}$ from hydrocarbons in produced gas and using the hydrocarbons for fuel and sales are offset by the large capital investment required for a membrane separation facility. Thus, re-injection of all produced gas without processing is economically more attractive than implementing a $\mathrm{CO}_{2}$ flood with gas processing.

4. The difference between a minimum- and-maximum cost option for installation of flow/injection lines and the $\mathrm{CO}_{2}$ supply is approximately $\$ 1.0$ million; however, the economics are still robust for both cases. With DOE cost sharing, the ROR is 56 percent with a PI of 11.5 to 1.

5. The ROR and PI are not significantly different for a process using blowdown after six years of $\mathrm{CO}_{2}$ injection versus the continuous $\mathrm{CO}_{2}$ injection case. However, the NPV is substantially less with blowdown (approximately $\$ 1.4$ million). The lower NPV is a result of lower oil recovery for the blowdown case $\left(800,000 \mathrm{STB}\left[127,000 \mathrm{~m}^{3}\right]\right.$ less than the continuous injection case).

Production data and injection gas requirements, including $\mathrm{CO}_{2}$ make-up purchases, were used to assess the financial merits of $\mathrm{CO}_{2}$ flood with an $8.0 \mathrm{MMCFGPD}\left(230,000 \mathrm{~m}^{3} / \mathrm{d}\right)$ total injection rate commencing January 1, 2000 (based on the 1998 evaluation). The economic assessment, using two compressor options, was conducted assuming the following conditions: (1) leased compressor (option 1 - \$19,500/option 2 - \$23,500 [same compressor with a different engine]), (2) $\mathrm{CO}_{2}$ supply line construction using the minimum-cost option $(\$ 825,000)$, (3) no gas processing, and (4) cost sharing by DOE. This assessment demonstrated that $\mathrm{CO}_{2}$ flooding with either of the compressor options provides an adequate flood response, an acceptable economic ROR of 32 percent, and a payout of 36 months. A discounted (10 percent) NPV of $\$ 5.9$ million could be realized by implementing a $\mathrm{CO}_{2}$ flood under both proposed conditions.

In summary, if the $\mathrm{CO}_{2}$ flood performs as modeled, it is a financially robust process for increasing the reserves of the Anasazi reservoir; however, the ROR and NPV are very sensitive to oil prices (figures 9-1 and 9-2). The oil price used in the 1998 study was \$20 per STB. Therefore, the plan was to re-run project economics before installation of injection facilities.

\section{Recommendations}

Based on the results of the completed geologic study, reservoir performance predictions, and the associated economic assessment of implementing a $\mathrm{CO}_{2}$ flood in the Anasazi reservoir, the following production scenario was recommended: 


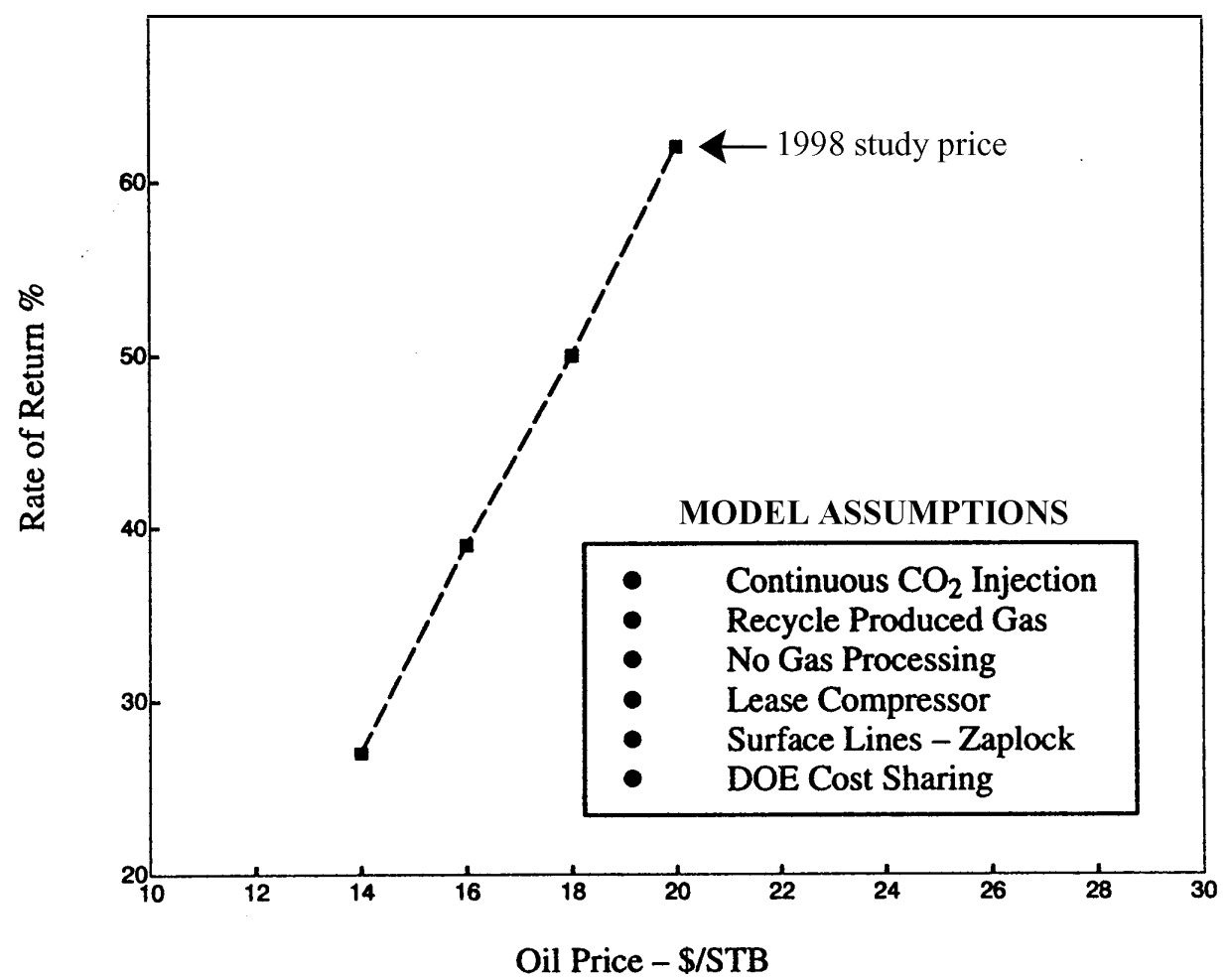

Figure 9-1. Rate of return versus price of oil, Anasazi field $\mathrm{CO}_{2}$ flood at high rate.

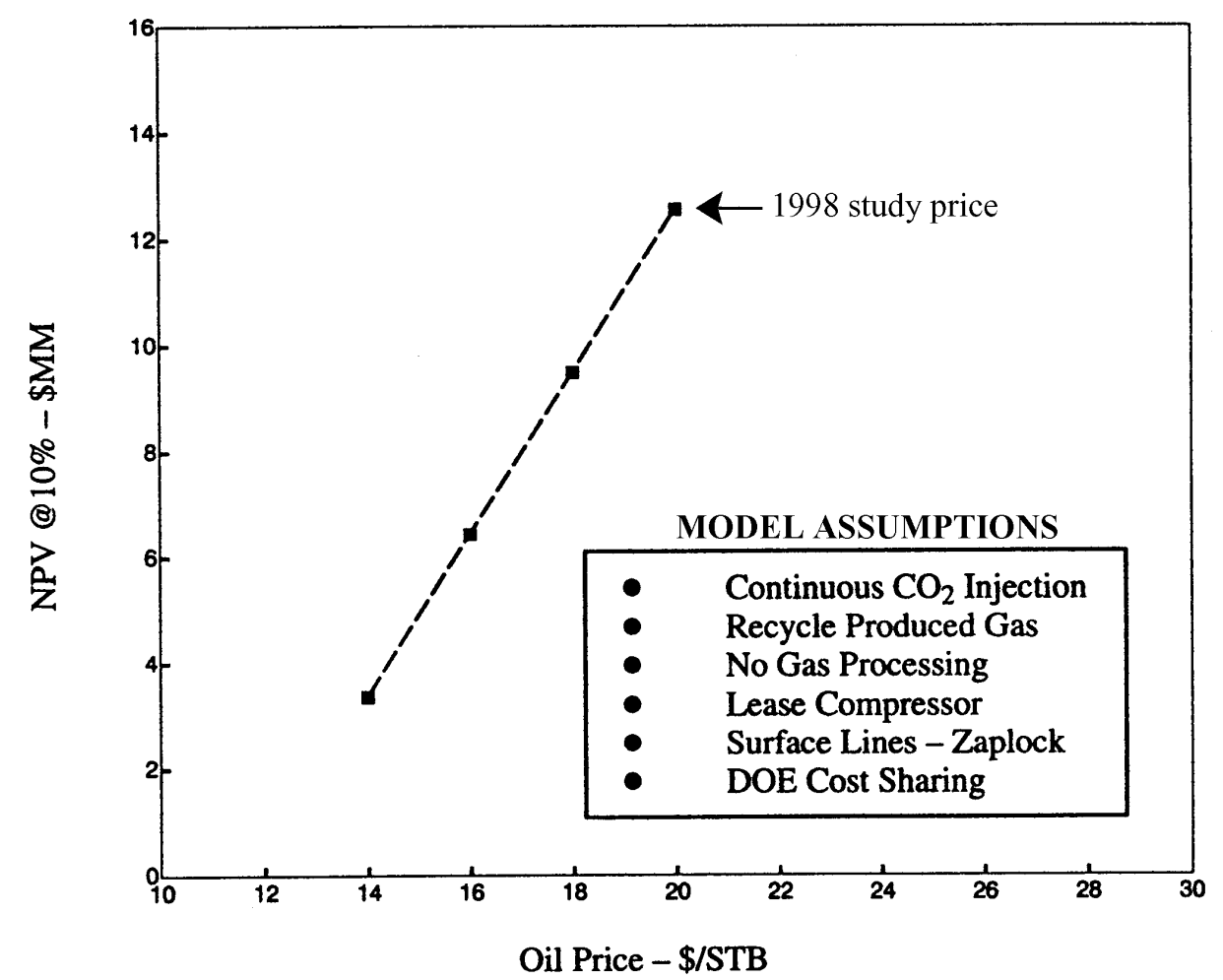

Figure 9-2. Net present value versus price of oil, Anasazi field $\mathrm{CO}_{2}$ flood at high rate. 
1. $\mathrm{A} \mathrm{CO}_{2}$-injection project should be implemented in the Anasazi reservoir.

2. $\mathrm{A} \mathrm{CO}_{2}$ injectivity field test should be conducted on the Anasazi No. $6 \mathrm{H}-1$ well, a project well in the western part of the field, to establish long-term injection rate data before committing to further Phase II work.

3. After the $\mathrm{CO}_{2}$ source is obtained and before injection facilities are installed for Anasazi field, economics should be re-run to see if the project is still economically feasible at current oil prices.

4. The main injection compressor should be leased rather than purchased to provide the most operating flexibility and least financial risk.

5. Produced gas processing is not required for a single field $\mathrm{CO}_{2}$-flood implementation case. It is not required from a reservoir-processing standpoint nor it is justified economically.

6. Horizontal well injectivity should be predicted from the appropriate well-test models after calibration with vertical well-test data.

\section{Runway Field}

\section{Economic Assessment of $\mathrm{CO}_{2}$ Flood}

Using reservoir-simulation-based performance predictions and current $\mathrm{CO}_{2}$-flood implementation costs, detailed economic assessments were conducted for five different $\mathrm{CO}_{2}$ flood options. This set of studies indicated that:

1. $\mathrm{A} \mathrm{CO}_{2}$ flood of the Runway reservoir had acceptable economics. With DOE participation, the project would have a ROR of 30 percent, a payout of 32 months, a PI of 5 to 1 , and a discounted (10 percent) NPV in excess of $\$ 3.1$ million. Even without DOE participation the economics remain acceptable with a ROR of 21 percent, a payout of 39 months, a PI of 2.8 to 1 , and a discounted NPV of almost \$2.0 million. The capital requirements would be \$2.789 million.

2. Based on the Anasazi study, leasing rather than purchasing a compressor was adopted for the Runway evaluation.

3. The difference between a minimum- and maximum-cost options for installation of flow/injection lines and the $\mathrm{CO}_{2}$ supply is approximately $\$ 233,000$; however, the economics are still acceptable. With DOE cost sharing, the ROR is 29 percent with a PI of 4.8 to 1 , and the discounted NPV is $\$ 2.9$ million.

4. Most economic evaluations exhibited negative cash flows in the year 2008, when operating costs exceed revenues. At this point the projects were terminated. However, the reservoir process should have been changed from continuous $\mathrm{CO}_{2}$ 
injection to blowdown and the economics re-run. The additional recovery from blowdown, without the operating costs associated with $\mathrm{CO}_{2}$ injection, would likely improve economic returns.

In summary, if the $\mathrm{CO}_{2}$ flood performs as modeled, it is a financially acceptable process for increasing the reserves of the Runway reservoir. As in Anasazi field, the ROR and NPV are very sensitive to oil prices (figures 9-3 and 9-4). Therefore economics should also be re-run before installation of injection facilities.

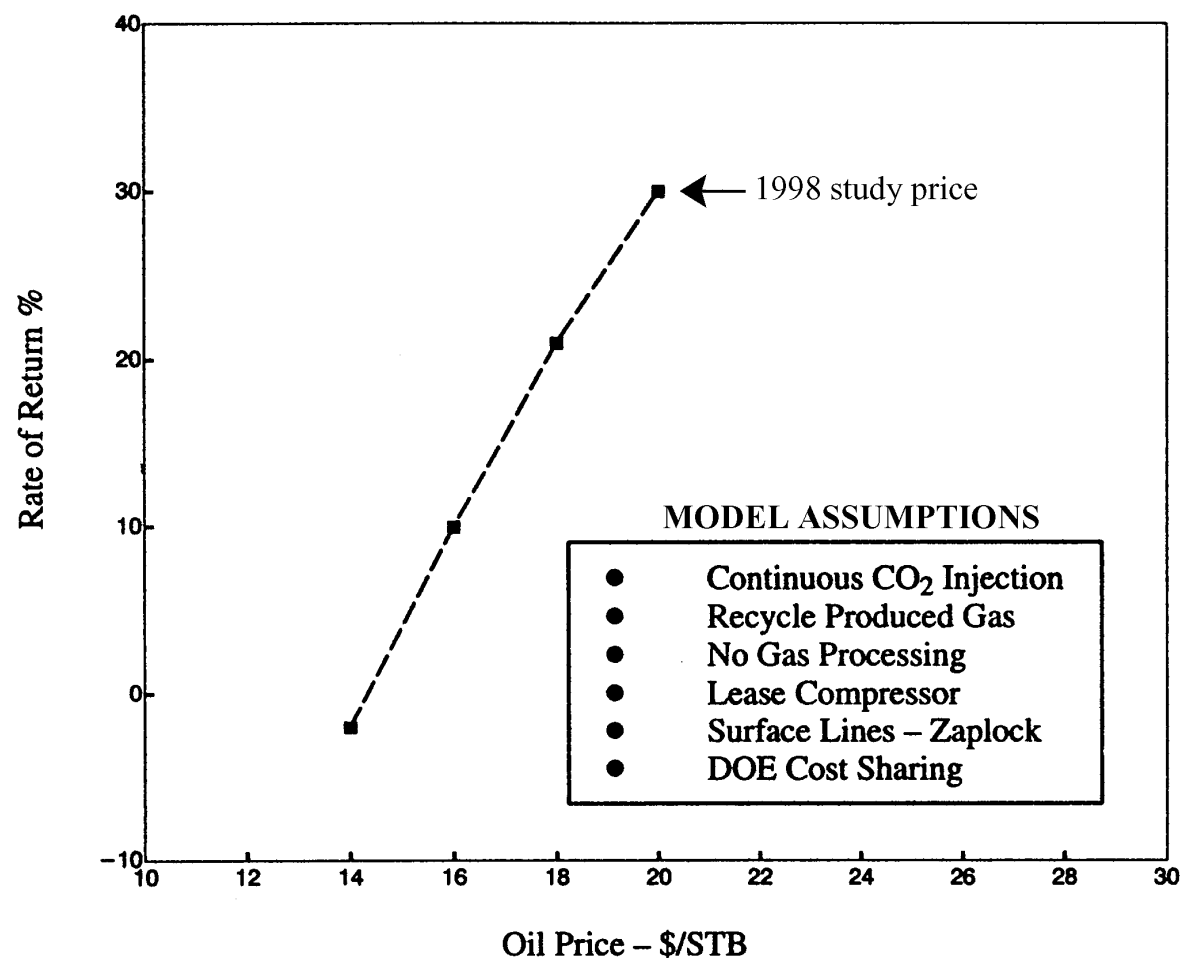

Figure 9-3. Rate of return versus price of oil, Runway field $\mathrm{CO}_{2}$ flood at high rate.

\section{Recommendations}

Based on the results of the completed geologic study, reservoir performance predictions, and economic evaluations using a \$20/STB price of a $\mathrm{CO}_{2}$ flood in Runway field, the following production scenario was recommended.

1. $\mathrm{A} \mathrm{CO}_{2}$-injection project could be implemented in the Runway reservoir.

2. $\quad \mathrm{A} \mathrm{CO}_{2}$ injectivity field test should be conducted on a Runway well to establish long-term injection rate data before committing to further Phase II work.

3. After the $\mathrm{CO}_{2}$ source is obtained and before injection facilities are installed for Runway field, economics should be re-run to see if the project is still economically feasible at current prices. 


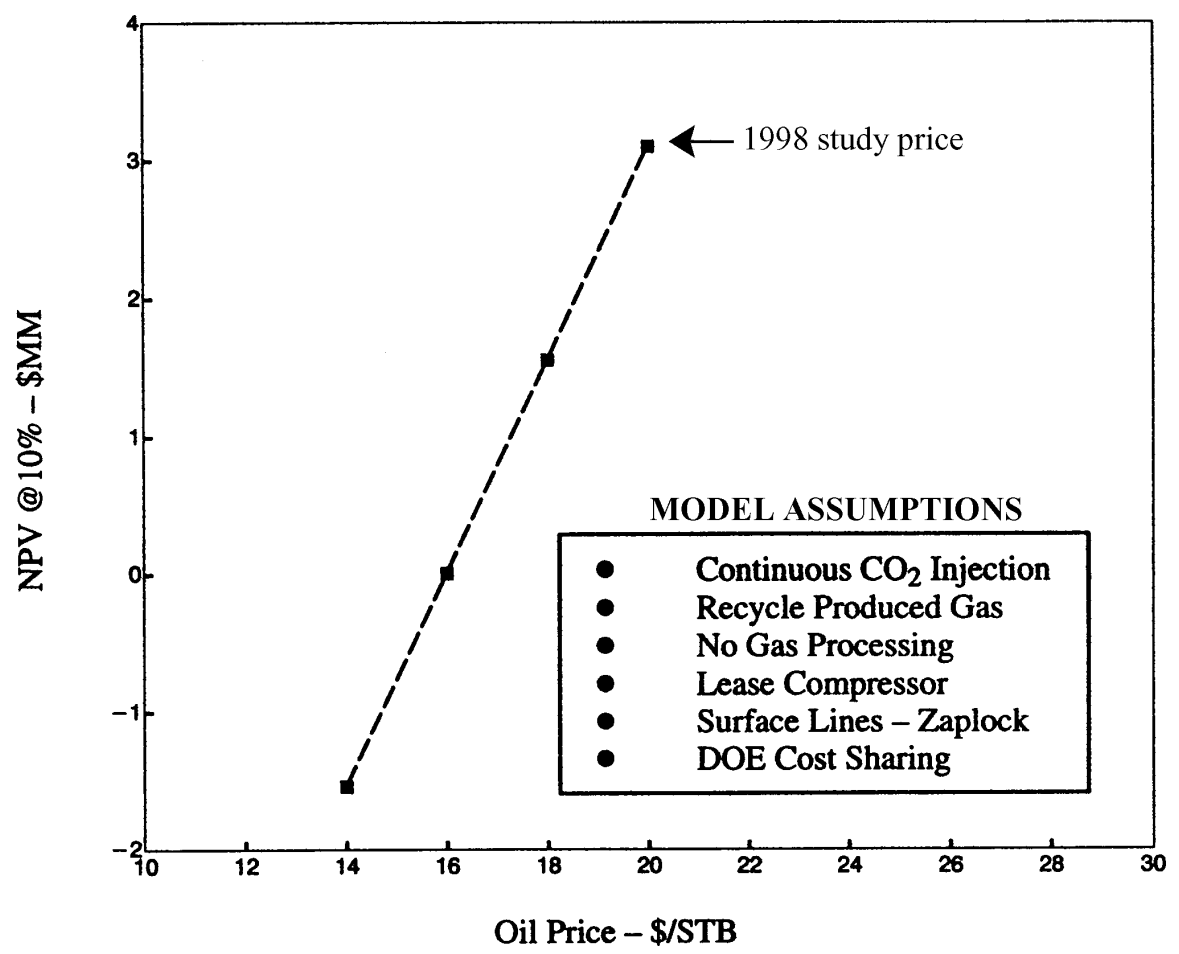

Figure 9-4. Net present value versus price of oil, Runway field $\mathrm{CO}_{2}$ flood at high rate.

4. The main injection compressor should be leased rather than purchased to provide the most operating flexibility and least financial risk.

5. The economic trade off of shutting in producers during reservoir fill-up versus continued production during fill-up should be assessed.

6. Horizontal well injectivity should be predicted from the appropriate well-test models after calibration with vertical well-test data.

7. Additional prediction runs should be completed to assess the economic effect of conversion to blowdown inn 2008 rather than terminating injection and production.

\section{Reserve and Recovery Determinations for Project Fields}

The cumulative production for the five project fields as of January 1, 2002 is summarized on table 3-1. Heron north field is currently shut-in (Utah Division of Oil, Gas and Mining, 2002). Primary recovery and original oil in place (OOIP) (table 9-1) were determined from volumetric reserve calculations, material balance calculations, and decline curve extrapolations, as well as from refined geologic characterization. These volumetric calculations were made by evaluating well logs and reservoir areal extent (as defined by seismic) coupled with reservoir geometry. Material-balance and decline-curve calculations utilized the production and pressure history. Knowing the OOIP and the primary recovery, the amount of 
oil left behind was calculated. Lastly, utilizing the results from the simulation studies of Anasazi and Runway fields, sweep efficiencies for $\mathrm{CO}_{2}$ flooding and the ultimate enhanced recovery were estimated for all project fields (table 9-1). Using the Runway and Anasazi average predicted $\mathrm{CO}_{2}$ flood recovery of remaining oil in place after primary recovery, 71.8 percent, the projected addition to reserves if $\mathrm{CO}_{2}$ flooding is also applied to project fields is over 8.2 MMSTB (1.3 million $\left.\mathrm{m}^{3}\right)$ of oil.

Table 9-1. Reserve and recovery determinations.

\begin{tabular}{|c|c|c|c|c|c|c|}
\hline \multirow{2}{*}{$\begin{array}{c}\text { Project } \\
\text { Field }\end{array}$} & \multirow{2}{*}{$\begin{array}{l}\text { OOIP* } \\
\text { (MSTB) }\end{array}$} & \multicolumn{2}{|c|}{ Primary Recovery } & \multirow{2}{*}{$\begin{array}{l}\text { ROIP** } \\
\text { (MSTB) }\end{array}$} & \multirow{2}{*}{$\begin{array}{c}\mathrm{CO}_{2} \text { Flood } \\
\text { Projected } \\
\text { Recovery } \\
\text { (MSTB) }\end{array}$} & \multirow{2}{*}{$\begin{array}{c}\mathrm{CO}_{2} \text { Flood } \\
\text { Recovery \% } \\
\text { ROIP }\end{array}$} \\
\hline & & Oil (MSTB) & Gas (MCF) & & & \\
\hline Anasazi† & 4,706 & 2,000 & $1,890,000$ & 2,706 & 2,208 & 81.6 \\
\hline Blue Hoga & $2,530 \ddagger$ & 321 & 968,000 & 2,209 & 1,586 & 71.8 \\
\hline Heron Nor & $2,640 \ddagger$ & 216 & $2,650,000$ & 2,424 & 1,740 & 71.8 \\
\hline Mule & $2,000 \ddagger$ & 454 & 288,000 & 1,546 & 1,110 & 71.8 \\
\hline Runway & 3,372 & 825 & $2,830,000$ & 2,547 & 1,577 & 61.9 \\
\hline \multicolumn{7}{|c|}{ * $\quad$ Original oil in place (thousand stock tank barrels [MSTB]), mound-core and supra-mound intervals (includes platform } \\
\hline \multicolumn{7}{|c|}{ Remaining oil in place } \\
\hline $\begin{array}{l}\mathrm{Hi} \\
\mathrm{Es}\end{array}$ & \multicolumn{5}{|c|}{ High rate case starting $\mathrm{CO}_{2}$ flood January 1,2000} & \\
\hline
\end{tabular}

\section{Conclusions}

Phase I (Budget Period I) of the project showed that a $\mathrm{CO}_{2}$ flood was technically superior to a waterflood and was economically feasible. For Anasazi field, an optimized $\mathrm{CO}_{2}$ flood is predicted to recover a total 4.21 MMSTB $\left(0.67\right.$ million $\left.\mathrm{m}^{3}\right)$ of oil. This represents an increase of $1.65 \mathrm{MMSTB}\left(0.26\right.$ million $\left.\mathrm{m}^{3}\right)$ of oil over predicted primary recovery at January 1 , 2012 (based on a $\mathrm{CO}_{2}$ flood start-up date during the year 2000). The projected 4.21 MMSTB of oil production represents in excess of 89 percent of the OOIP in the mound complex and 36.8 percent of the OOIP of the total system modeled. For Runway field, the best $\mathrm{CO}_{2}$ flood is predicted to recover a total of 2.4 MMSTB $\left(0.38\right.$ million $\left.\mathrm{m}^{3}\right)$ of oil. This represents an increase of $1.58 \mathrm{MMSTB}\left(0.25\right.$ million $\left.\mathrm{m}^{3}\right)$ of oil over predicted primary depletion recovery at January 1, 2012 (also based on a $\mathrm{CO}_{2}$ flood start-up date during the year 2000). The projected 2.4 MMSTB of oil production represents 71 percent of the OOIP in the mound complex and 48 percent of the OOIP of the total system modeled, excluding the Ismay zone above the Desert Creek zone.

The UGS recommended continuation of the project into Phase II (Budget Period II) with a field demonstration of the technique on the Anasazi field (and/or Runway field). The field demonstration included: conducting a $\mathrm{CO}_{2}$ injection test(s), obtaining a $\mathrm{CO}_{2}$ source and fuel gas for the compressor, rerunning project economics, drilling a development well(s) (vertically or horizontally), purchasing and installing injection facilities, monitoring field performance, and validation and evaluation of the techniques.

The demonstration would prove (or disprove) $\mathrm{CO}_{2}$-flood viability and thus help determine whether the technique can be applied to the other small carbonate buildup reservoirs in the Paradox Basin. The financial impact of simultaneous or sequential flooding of a series of reservoirs should also be assessed. This would quantify the upside potential of $\mathrm{CO}_{2}$ flooding 
for the entire basin from both a reserves and an economic standpoint. The experience gained in matching historic production and predicting the performance of the Anasazi and Runway reservoirs indicates that the overall mound geometry and internal facies architecture are critical to matching and predicting performance. Thus, each mound will likely require an individual reservoir study to quantify its $\mathrm{CO}_{2}$-flood potential and identify the appropriate implementation strategy for maximum oil recovery. 


\title{
CHAPER X \\ IMPLEMENTATION OF PILOT CO 2 FLOOD DEMONSTRATION
}

\author{
Thomas C. Chidsey, Jr. \\ Utah Geological Survey
}

\section{Plans and Delays}

Results from Budget Period I of this project showed that a $\mathrm{CO}_{2}$ flood was technically superior to a waterflood and was economically feasible on typical, small, shallow-shelf, carbonate-buildup reservoirs in the Paradox Basin. Based on the geologic characterization study, reservoir performance predictions, and the associated economic assessment of implementing a $\mathrm{CO}_{2}$ flood, Anasazi field was selected for the field pilot-flood demonstration. If the $\mathrm{CO}_{2}$ flood performed as predicted, it would be a financially robust process for increasing the reserves of the Anasazi field and similar small fields in the basin.

Budget Period II of the project was intended to involve the implementation of a pilot $\mathrm{CO}_{2}$-flood demonstration on Anasazi field. Obtaining a $\mathrm{CO}_{2}$ source was the key to beginning this demonstration. In December 1999, the UGS requested a three-year, no-cost extension for Budget Period II. At the time of the request, there was only one $\mathrm{CO}_{2}$ source in the area, a pipeline (figure 1-1) which is now owned and operated by ExxonMobil (formerly Mobil Oil Corporation). The $\mathrm{CO}_{2}$ line was operating at full capacity supplying $\mathrm{CO}_{2}$ to wells on the north side of the San Juan River as part of a large $\mathrm{CO}_{2}$ flood of the giant Greater Aneth field. In 2001, about 15.5 BCF of $\mathrm{CO}_{2}$ was injected into the Desert Creek reservoir in the field (Utah Division of Oil, Gas and Mining files). During the year, monthly injection of $\mathrm{CO}_{2}$ averaged 0.4 BCF. Plans to expand the pipeline capacity and extend it south across the river, closer to Anasazi field, were delayed about a year and a half due to low oil prices in 1998 and early 1999, as well as a backlog of higher priority projects by the operators of Greater Aneth field. These factors, combined with uncertainty over the merger of Mobil and Exxon, resulted in a delay in the availability of $\mathrm{CO}_{2}$ to Anasazi field for at least two additional years. Thus, a further extension was granted so that Budget Period II would end August 31, 2005.

In 2001, all project fields (Anasazi, Blue Hogan, Heron North, Mule, and Runway; figure 1-1) operated by the UGS's original industry partner, Harken Energy Corporation, were sold to the Rim Energy Companies of Denver, Colorado. At this time the $\mathrm{CO}_{2}$ pipeline had been extended south of the San Juan River to other parts of Greater Aneth field, and further expansion was in the planning stages. The field demonstration requires three years - one year to implement and two years of monitoring and evaluation. For this phase to be completed by 2005, the demonstration project needed to begin in August 2002. This did not happen because Rim reports that it continues to have difficulty obtaining APDs and approved right-of-ways due to assignability problems with the Navajo Nation, the landowners.

\section{Options and Current Status}

The UGS had a contract with Harken, but has no contract with the current field operator, Rim. Rim verbally expressed interest in performing the demonstration, but made no guarantees and considered 2002 oil prices too low to proceed. They could not predict when, if ever, their problems with the Navajo Nation would be resolved. 
The UGS was left with the following options:

1. continue to extend the project indefinitely in hopes the operator would work things out with the Navajo Nation and would eventually participate in the demonstration project once that occurs,

2. seek out other operators of similar Paradox Basin fields outside of the Navajo Nation who are willing to cost-share the demonstration project, or

3. terminate the project without a field pilot-flood demonstration.

The problem with option 1 is obvious in that an indefinite extension may never achieve anything, and thus the funding designated for the demonstration should be redirected to other projects that have a better chance of completion. The problem with option 2 is that the UGS would not be able to conduct any reservoir characterization, modeling, or $\mathrm{CO}_{2}$ flood simulation on substitute fields outside the Navajo Nation. The project was originally designed to perform such tasks and prove the predictions with the field demonstration. Carbon dioxide sources could also be a problem because there is still only one pipeline in the region (operators would have to drill for $\mathrm{CO}_{2}$ without the benefit of knowing whether a $\mathrm{CO}_{2}$ flood has been successful in similar fields -- the original intent of the project). That leaves option 3, termination of the project.

The UGS and DOE elected to terminate the project without the benefit of the field pilotflood demonstration. The complete reservoir modeling and simulation studies for Anasazi and Runway fields are available from the UGS (Culham and Lorenze, 2002). Most operators in the basin are small independent companies that need to see a successful and economically viable $\mathrm{CO}_{2}$-flood demonstrated on a small field before they will invest in $\mathrm{CO}_{2}$ acquisition, new pipelines, injection wells, and additional field facilities. The research, data compilation, maps, desciptions and analyses, internet web site, and published results of this project (see Appendix) can provide the tools for this to occur in the small reservoirs of the Paradox Basin and other shallow-shelf carbonate deposits. 


\section{REFERENCES}

Baars, D.L., 1966, Pre-Pennsylvanian paleotectonics-key to basin evaluation and petroleum occurrences in Paradox Basin, Utah and Colorado: American Association of Petroleum Geologists Bulletin, v. 50, no. 10, p. 2082-2111 (Ch-2).

Baars, D.L., and Stevenson, G.M., 1982, Subtle stratigraphic traps in Paleozoic rocks of Paradox Basin, in Halbouty, M.T., editor, The deliberate search for the subtle trap: American Association of Petroleum Geologists Memoir 32, p. 131-158 (Ch-2).

Beall, J.L., Gordon, I.T., Gournay, J.P., Kirkland, B.L., and White, J.V., 1996, Analysis of porosity in lower Ismay phylloid algal packstone using high-resolution computed x-ray tomography [abs.]: American Association of Petroleum Geologists Annual Convention, Program with Abstracts, p. A13 (Ch-3).

Bebout, D.G., and Loucks, R.G., 1984, Handbook for logging carbonate rocks: Bureau of Economic Geology, University of Texas at Austin, Handbook 5, 43 p. (Ch-3).

Best, D.A., Wright, F.M., III, Sagar, Rajiv, and Weber, J.J., 1995, Contribution of outcrop data to improve understanding of field performance - rock exposures at Eight Foot Rapids tied to the Aneth field, in Stoudt, E.L., and Harris, P.M., editors, Hydrocarbon reservoir characterization - geologic framework and flow unit modeling: SEPM (Society for Sedimentary Geology) Short Course No. 34, p. 31-50 (Ch-3, Ch-4, Ch-6).

Bourdet, D, 1985, Pressure behavior of layered reservoirs with crossflow: Society of Petroleum Engineers Technical Paper 13628, California Regional Meeting, Bakersfield, CA, p. 405-416 (Ch-7).

Brinton, Lisë, 1986, Deposition and diagenesis of middle Pennsylvanian (Desmoinesian) phylloid algal banks, Paradox Formation, Ismay zone, Ismay field and San Juan Canyon, Paradox Basin, Utah and Colorado: Golden, Colorado School of Mines, unpublished M.S. thesis, 315 p. (Ch-3, Ch-4).

Chidsey, T.C., Jr., 1997, Increased oil production and reserves utilizing secondary/tertiary recovery techniques on small reservoirs in the Paradox Basin, Utah - annual report: U.S. Department of Energy, DOE/BC/14988-8, 117 p. (Ch-2, Ch-3, Ch-7).

Chidsey, T.C., Jr., and Eby, D.E., 1997, Heron North field, Navajo Nation, San Juan County, Utah - a case study for small calcarenite carbonate buildups [abs.]: American Association of Petroleum Geologists Bulletin, v. 81, no. 7, p. 1220 (Ch-2).

---2000a, 320-million-year old limestones that produce oil in southeastern Utah have modern counterparts: Utah Geological Survey, Survey Notes, v. 32, no. 3, p. 10-11 (Ch-4).

---2000b, Facies of the Paradox Formation, southeastern Utah, and modern analogs - tools for exploration and development [abs.]: American Association of Petroleum Geologists 
Bulletin Annual Convention, Official Program with Abstracts, v. 9, p. A26 (Ch-4).

Chidsey, T.C., Jr., Brinton, Lisë, Eby, D.E., and Hartmann, Kris, 1996, Carbonate mound reservoirs in the Paradox Formation - an outcrop analogue along the San Juan River, southeastern Utah, in Huffman, A.C., Jr., Lund, W.R., and Godwin, L.H., editors, Geology and resources of the Paradox Basin: Utah Geological Association Publication 25, p. 139-156 (Ch-4, Ch-6).

Chidsey, T.C., Jr., Eby, D.E., and Lorenz, D.M., 1996, Geological and reservoir characterization of small shallow-shelf fields, southern Paradox Basin, Utah, in Huffman, A.C., Jr., Lund, W.R., and Godwin, L.H., editors, Geology and resources of the Paradox Basin: Utah Geological Association Publication 25, p. 39-56 (Ch-2, Ch-3, Ch-4, Ch-6).

Chidsey, T.C., Jr., Eby, D.E., Groen, W.G., Hartmann, Kris, and Watson, M.C., 1996a, Anasazi, in Hill, B.G., and Bereskin, S.R., editors, Oil and gas fields of Utah: Utah Geological Association 22 (Addendum), non-pagenated (Ch-3, Ch-6).

---1996b, Blue Hogan, in Hill, B.G., and Bereskin, S.R., editors, Oil and gas fields of Utah: Utah Geological Association 22 (Addendum), non-pagenated (Ch-3).

---1996c, Heron North, in Hill, B.G., and Bereskin, S.R., editors, Oil and gas fields of Utah: Utah Geological Association 22 (Addendum), non-pagenated (Ch-2, Ch-3).

---1996d, Mule, in Hill, B.G., and Bereskin, S.R., editors, Oil and gas fields of Utah: Utah Geological Association 22 (Addendum), non-pagenated (Ch-3).

---1996e, Runway, in Hill, B.G., and Bereskin, S.R., editors, Oil and gas fields of Utah: Utah Geological Association 22 (Addendum), non-pagenated (Ch-3, Ch-6).

Culham, W.E., and Lorenz, D.M., 2002, Reservoir modeling and compositional simulation of primary depletion, waterflooding, and carbon dioxide flooding of a small Pennsylvanian carbonate mound complex, Anasazi field, Paradox Basin, Utah: Utah Geological Survey Open-File Report Report (Ch-10).

---2002, Reservoir modeling and compositional simulation of primary depletion, and carbon dioxide flooding of a small Pennsylvanian carbonate mound complex, Runway field, Paradox Basin, Utah: Utah Geological Survey Open-File Report (Ch-10).

D.B. Robinson Research Ltd., 1995, Laboratory PVT program for Harken Energy reservoir fluid phase 1: Unpublished report for REGA Inc., D.B. Robinson Research Ltd. file 205136, 44 p (Ch-7).

Denton, G.H., and Hughes, T.J., 1983, Milankovitch theory of ice ages: hypothesis of ice-sheet linkage between regional insolation and global climate: Quaternary Research, v. 20, p. 125-144 (Ch-2). 
Dunham, R.J., 1962, Classification of carbonate rocks according to depositional texture, in Ham, W.E., editor, Classification of carbonate rocks: American Association of Petroleum Geologists Memoir 1, p. 108-121 (Ch-3).

Eby, D.E., Groen, W.G., and Johnson, J.F., 1993, Composition of seismically identified satellite mounds surrounding Greater Aneth field, southeast Utah [abs.]: American Association of Petroleum Geologists Bulletin, v. 77, no. 8, p. 1446-1447 (Ch-3).

Embry, A.R., and Klovan, J.E., 1971, A Late Devonian reef tract on northeastern Banks Island, Northwest Territories: Canadian Petroleum Geologists Bulletin, v. 19, p. 730-781 (Ch$3)$.

Fetzner, R.W., 1960, Pennsylvanian paleotectonics of the Colorado Plateau: American Association of Petroleum Geologists Bulletin, v. 44, no. 8, p. 1371-1413 (Ch-2).

Friedman, G.M., and Sanders, J.E., 1978, Principles of sedimentology: New York, John Wiley and Sons, p. 149 (Ch-3).

Gianniny, G. L., and Simo, J.A.T., 1996, Implications of unfilled accommodation space for sequence stratigraphy on mixed carbonate-siliciclastic platforms - an example from the lower Desmoinesian (Middle Pennsylvanian), southwestern Paradox Basin, Utah, in Longman, M.W., and Sonnenfeld, M.D., editors, Paleozoic systems of the Rocky Mountain region: Rocky Mountain Section, SEPM (Society for Sedimentary Geology), p. 213-234 (Ch-3, Ch-4).

Goldhammer, R.K., Oswald, E.J., and Dunn, P.A., 1991, Hierarchy of stratigraphic forcing example from Middle Pennsylvanian shelf carbonates of the Paradox Basin, in Franseen, E.K., Watney, W.L., Kendall, C.G., and Ross, W., editors, Sedimentary modeling: Kansas Geological Survey Bulletin 233, p. 361-413 (Ch-4).

---1994, High frequency, glacio-eustatic cyclicity in Middle Pennsylvanian of the Paradox Basin - an evaluation of Milankovitch forcing, in deBoer, P.L., and Smith, D.G., editors, Orbital forcing and cyclic sequences: Special Publication of the International Association of Sedimentologists 19, p. 243-283 (Ch-4).

Grammar, G.M., Eberli, G.P., Van Buchem, F.S.P., Stevenson, G.M., and Homewood, Peter, 1996, Application of high-resolution sequence stratigraphy to evaluate lateral variability in outcrop and subsurface - Desert Creek and Ismay intervals, Paradox Basin, in Longman, M.W., and Sonnenfeld, M.D., editors, Paleozoic systems of the Rocky Mountain region: Rocky Mountain Section, SEPM (Society for Sedimentary Geology), p. 235-266 (Ch-3, Ch-4).

Harris, P.M, and Kowalik, W.S., editors, 1994, Satellite images of carbonate depositional settings: American Association of Petroleum Geologists Methods in Exploration Series No. 11, p. 61 (Ch-4). 
Heckel, P.H., 1977, Origin of phosphatic black shale facies in Pennsylvanian cyclothems of Mid-Continent North America: American Association of Petroleum Geologists Bulletin, v. 61 , no. 7 , p. 1045-1068 (Ch-2).

---1983, Diagenetic model for carbonate rocks in midcontinent Pennsylvanian eustatic cyclothems: Journal of Sedimentary Petrology, v. 53, p. $733-759$ (Ch-2).

---1986, Sea-level curve for Pennsylvanian eustatic marine transgressive-regressive depositional cycles along midcontinent outcrop belt, North America: Geology, v. 14, p. 330-334 (Ch2).

Hirasaki, G.J., Rohan, J.A., and Dubey, S.T., 1990, Wettability evaluation during restored-state core analysis: Society of Petroleum Engineers Technical Paper 20506, 65th Annual Technical Conference and Exhibition, Production Operations and Engineering Volume, p. 361-375 (Ch-7).

Hite, R.J., 1960, Stratigraphy of the saline facies of the Paradox Member of the Hermosa Formation of southeastern Utah and southwestern Colorado, in Geology of the Paradox Basin: Four Corners Geological Society, Third Field Conference, p. 86-89 (Ch-2).

---1970, Shelf carbonate sedimentation controlled by salinity in the Paradox Basin, southeast Utah, in Ran, J.L., and Dellwig, L.F., editors, Third symposium on salt: Northern Ohio Geological Society, v. 1, p. 48-66 (Ch-2).

Hite, R.J., and Buckner, D.H., 1981, Stratigraphic correlation, facies concepts and cyclicity in Pennsylvanian rocks of the Paradox Basin, in Wiegand, D.L., editor, Geology of the Paradox Basin: Rocky Mountain Association of Geologists 1981 Field Conference, p. 147-159 (Ch-2).

Johnson, J.F., and Groen, W.G., 1993, Seismic structure and seismic stratigraphy of the giant Aneth field and its satellite fields of southeast Utah [abs.]: American Association of Petroleum Geologists Bulletin, v. 77, no. 8, p. 1452-1453 (Ch-3).

Imbrie, John, and Imbrie, J.Z., 1980, Modeling the climatic response to orbital variations: Science, v. 207, p. 943-953 (Ch-2).

Longman, M.W., 1980, Carbonate diagenetic textures from nearshore diagenetic environments: American Association of Petroleum Geologists Bulletin, v. 64, no. 4, p. 461-487 (Ch-3).

Lorenz, D.M., Culham, W.E., Chidsey, T.C., Jr., Hartmann, Kris, 1997, Reservoir modeling of the Anasazi carbonate mound, Paradox basin, Utah [abs.]: American Association of Petroleum Geologists Bulletin Annual Convention, Official Program with Abstracts, v. 6, p. A71-72 (Ch-8).

---1998, Reservoir characterization of a heterolithic carbonate mound, Runway field, Paradox 
basin, Utah [abs.]: American Association of Petroleum Geologists Annual Convention Extended Abstracts, v. II, p. A-415 (Ch-8).

Ohlen, H.R., and McIntyre, L.B., 1965, Stratigraphy and tectonic features of Paradox Basin, Four Corners area: American Association of Petroleum Geologists Bulletin, v. 49, no. 11, p. 2020-2040 (Ch-2).

Parrish, J.T., 1982, Upwelling and petroleum source beds, with reference to the Paleozoic: American Association of Petroleum Geologists Bulletin, v. 66, no. 6, p. 750-774 (Ch-2).

Peterson, J.A., 1966, Stratigraphic vs. structural controls on carbonate-mound accumulation, Aneth area, Paradox Basin: American Association of Petroleum Geologists Bulletin, v. 50, no. 10, p. 2068-2081 (Ch-2).

Peterson, J.A., and Hite, R.J., 1969, Pennsylvanian evaporite-carbonate cycles and their relation to petroleum occurrence, southern Rocky Mountains: American Association Petroleum Geologists Bulletin, v. 53, no. 4, p. 884-909 (Ch-2).

Peterson, J.A., and Ohlen, H.R., 1963, Pennsylvanian shelf carbonates, Paradox Basin, in Bass, R.O., editor, Shelf carbonates of the Paradox basin: Four Corners, Geological Society Symposium, 4th Field Conference, p. 65-79 (Ch-2).

Scholle, P.A., and James, N.P., 1996, Arid and semiarid carbonate/evaporite systems: part 2 marginal marine to nonmarine settings: Society for Sedimentary Geology (SEPM) Photo CD-7 (Ch-4).

Simo, J.A.T., Gianniny, G.L., and De Miranda, D.R., 1994, Contrasting facies successions in cyclic Pennsylvanian and Cretaceous mixed carbonate-siliciclastic shelves [abs]: American Association of Petroleum Geologists, Annual Convention Program with Abstracts, p. 259 (Ch-4).

TerraTek, Inc., 1995, Compressibility of carbonate from the Anasazi No. 1 and No. 6H-1 wells: Unpublished report for REGA Inc., no. TR96-23, 20 p. (Ch-7).

Utah Division of Oil, Gas and Mining, 2002, Oil and gas production report, December 2001: non-paginated (Ch-3, Ch-5, Ch-7, Ch-9).

Weber, L.J., Sarg, J.F., and Wright, F.M., 1995, Sequence stratigraphy and reservoir delineation of the Middle Pennsylvanian (Desmoinesian), Paradox Basin and Aneth field, Milankovitch sea-level changes, cycles, and reservoirs on carbonate platforms in greenhouse and ice-house worlds: SEPM (Society for Sedimentary Geology) Short Course No. 35, p. 1-81 (Ch-3, Ch-4).

Weber, L.J., Wright F.M., Sarg, J.F., Shaw, E., Harman, L.P., Vanderhill, J.B., and Best, D.A., 1995, Reservoir delineation and performance - application of sequence stratigraphy and integration of petrophysics and engineering data, Aneth field, southeast Utah, U.S.A., in 
Stoudt, E.L., and Harris, P.M., editors, Hydrocarbon reservoir characterization geologic framework and flow unit modeling: SEPM (Society for Sedimentary Geology) Short Course No. 34, p. 1-29 (Ch-3, Ch-4).

Westport Technology Center International, 1995, Harken Energy special core analysis Anasazi 6H: Unpublished report for Harken Energy Corporation, no. WTCI95-201, 76 p. (Ch-7). 


\section{APPENDIX}

\section{UTAH GEOLOGICAL SURVEY DOE PARADOX BASIN CLASS II PROJECT PUBLICATIONS}

\section{Papers}

Chidsey, T.C., Jr., Brinton, Lisë, and Eby, D.E., 1996, Carbonate mound reservoirs in the Paradox Formation - an outcrop analogue along the San Juan River, southeastern Utah, in Huffman, A.C., Jr., Lund, W.R., and Godwin, L.H., editors, Geology and resources of the Paradox basin: Utah Geological Association Publication 25, p. 139-156.

Chidsey, T.C., Jr., Eby, D.E., Groen, W.G., Hartmann, Kris, and Watson, M.C., 1996, Anasazi, in Hill, B.G., and Bereskin, S.R., editors, Oil and gas fields of Utah: Utah Geological Association 22 (Addendum), non-pagenated.

Chidsey, T.C., Jr., Eby, D.E., Groen, W.G., Hartmann, Kris, and Watson, M.C., 1996, Blue Hogan, in Hill, B.G., and Bereskin, S.R., editors, Oil and gas fields of Utah: Utah Geological Association 22 (Addendum), non-pagenated.

Chidsey, T.C., Jr., Eby, D.E., Groen, W.G., Hartmann, Kris, and Watson, M.C., 1996, Heron North, in Hill, B.G., and Bereskin, S.R., editors, Oil and gas fields of Utah: Utah Geological Association 22 (Addendum), non-pagenated.

Chidsey, T.C., Jr., Eby, D.E., Groen, W.G., Hartmann, Kris, and Watson, M.C., 1996, Mule, in Hill, B.G., and Bereskin, S.R., editors, Oil and gas fields of Utah: Utah Geological Association 22 (Addendum), non-pagenated.

Chidsey, T.C., Jr., Eby, D.E., Groen, W.G., Hartmann, Kris, and Watson, M.C., 1996, Runway, in Hill, B.G., and Bereskin, S.R., editors, Oil and gas fields of Utah: Utah Geological Association 22 (Addendum), non-pagenated.

Chidsey, T.C., Jr., Eby, D.E., and Lorenz, D.M., 1996, Geological and reservoir characterization of small shallow-shelf fields, southern Paradox Basin, Utah, in Huffman, A.C., Jr., Lund, W.R., and Godwin, L.H., editors, Geology and resources of the Paradox basin: Utah Geological Association Publication 25, p. 39-56.

Chidsey, T.C., Jr., 1998, Paradox Basin project yields successful horizontal well: Utah Geological Survey, Survey Notes, v. 31, no. 1, p. 3-4.

Montgomery, S.L., Chidsey, T.C., Jr., Eby, D.E., Lorenz, D.M., and Culham, W.E., 1999, Pennsylvanian carbonate buildups, Paradox Basin - increasing reserves in heterogeneous, shallow-shelf reservoirs: American Association of Petroleum Geologists Bulletin, v. 83, no. 2, p. 193-210. 
Montgomery, S.L., Chidsey, T.C., Jr., Eby, D.E., Lorenz, D.M., and Culham, W.E., 1999, Paradox study shows big oil potential with $\mathrm{CO}_{2}$ : Oil \& Gas Journal, v. 97, no. 18, p. 128-134.

Chidsey, T.C., Jr., and Eby, D.E., 2000, 320-million old limestones that produce oil in southeastern Utah have modern counterparts: Utah Geological Survey, Survey Notes, v. 32, no. 3, p. 10-11.

Culham, W.E., and Lorenz, D.M., in press, Reservoir modeling and compositional simulation of primary depletion, waterflooding, and carbon dioxide flooding of a small Pennsylvanian carbonate mound complex, Anasazi field, Paradox Basin, Utah: Utah Geological Survey Open-File Report.

Culham, W.E., and Lorenz, D.M., in press, Reservoir modeling and compositional simulation of primary depletion, and carbon dioxide flooding of a small Pennsylvanian carbonate mound complex, Runway field, Paradox Basin, Utah: Utah Geological Survey OpenFile Report.

Chidsey, T.C., Jr., and Eby, D.E., in preparation, Catalogue of pore types and diagenisis from the Pennyslvanian Paradox Formation, southeastern Utah: Utah Geological Survey Open-File Report on compact disc.

\section{Annual Technical Progress Reports}

Chidsey, T.C., Jr., 1997, Increased oil production and reserves utilizing secondary/tertiary recovery techniques on small reservoirs in the Paradox Basin, Utah - annual report, June 1995 - February 1996): U.S. Department of Energy, DOE/BC/14988-8, 117 p.

Chidsey, T.C., Jr., 1997, Increased oil production and reserves utilizing secondary/tertiary recovery techniques on small reservoirs in the Paradox Basin, Utah - annual report, February 1996 - February 1997): U.S. Department of Energy, DOE/BC/14988-9, 65 p.

Chidsey, T.C., Jr., and Allison, M.L., 1998, Increased oil production and reserves utilizing secondary/tertiary recovery techniques on small reservoirs in the Paradox Basin, Utah annual report, February 1997 - February 1998): U.S. Department of Energy, DOE/BC/14988-10, 66 p.

Chidsey, T.C., Jr., Eby, D.E., Lorenz, D.M., and Culham, W.E., 1999, Increased oil production and reserves utilizing secondary/tertiary recovery techniques on small reservoirs in the Paradox Basin, Utah - annual report, February 1998 - February 1999): U.S. Department of Energy, DOE/BC/14988-12, 47 p.

Chidsey, T.C., Jr., 2000, Increased oil production and reserves utilizing secondary/tertiary recovery techniques on small reservoirs in the Paradox Basin, Utah - annual report, February 1999 - February 2000): U.S. Department of Energy, DOE/BC/14988-13, 15 p. 
Chidsey, T.C., Jr., 2001, Increased oil production and reserves utilizing secondary/tertiary recovery techniques on small reservoirs in the Paradox Basin, Utah - annual report, February 2000 - February 2001): U.S. Department of Energy, DOE/BC/14988-14, 20 p.

\begin{abstract}
s
Chidsey, T.C., Jr., and Eby, D.E., 1996, Geological and reservoir characterization of shallowshelf carbonate fields, southern Paradox Basin, Utah [abs.]: American Association of Petroleum Geologists Bulletin Annual Convention, Official Program with Abstracts, v. 5, p. A10.

Chidsey, T.C., Jr., Morgan, C.D., Eby, D.E., Brinton, Lisë, and Hartmann, Kris, 1996, Carbonate mound reservoirs in the Paradox Formation - an outcrop analogue along the San Juan River, southeastern Utah [abs.]: American Association of Petroleum Geologists Bulletin, v. 80, no. 6, p. 968.

Lorenz, D.M., Culham, W.E., Chidsey, T.C., Jr., Hartmann, Kris, 1997, Reservoir modeling of the Anasazi carbonate mound, Paradox Basin, Utah [abs.]: American Association of Petroleum Geologists Bulletin Annual Convention, Official Program with Abstracts, v. 6, p. A71-72.
\end{abstract}

Chidsey, T.C., Jr., and Eby, D.E., 1997, Heron North field, Navajo Nation, San Juan County, Utah - a case study for small calcarenite carbonate buildups [abs.]: American Association of Petroleum Geologists Bulletin, v. 81, no. 7, p. 1220.

Lorenz, D.M., Culham, W.E., Chidsey, T.C., Jr., Hartmann, Kris, 1998, Reservoir characterization of a heterolithic carbonate mound, Runway field, Paradox Basin, Utah [abs.]: American Association of Petroleum Geologists Annual Convention Extended Abstracts, v. II, p. A-415.

Chidsey, T.C., Jr., and Eby, D.E., 1999, Diagenetic characterization of shallow-shelf carbonate reservoirs, Pennsylvanian Paradox Formation, southern Paradox Basin, Utah [abs.]: American Association of Petroleum Geologists Bulletin Annual Convention, Official Program with Abstracts, v. 8, p. A24.

Chidsey, T.C., Jr., and Eby, D.E., 1999, Mule field in the Paradox Basin of southeastern Utah a case study for small carbonate buildups, horizontal drilling, and carbon dioxide flooding [abs.]: American Association of Petroleum Geologists Bulletin, v. 83, no. 7, p. 1180-1181.

Chidsey, T.C., Jr., and Eby, D.E., 2000, Facies of the Paradox Formation, southeastern Utah, and modern analogs - tools for exploration and development [abs.]: American Association of Petroleum Geologists Bulletin Annual Convention, Official Program with Abstracts, v. 9, p. A26. 


\section{Utah Geological Survey Internet Web Site}

Project Page: http://geology.utah.gov/emp/PARADOX/index.htm

\section{Utah Geological Survey Petroleum News}

see issues 1996 through 2001 